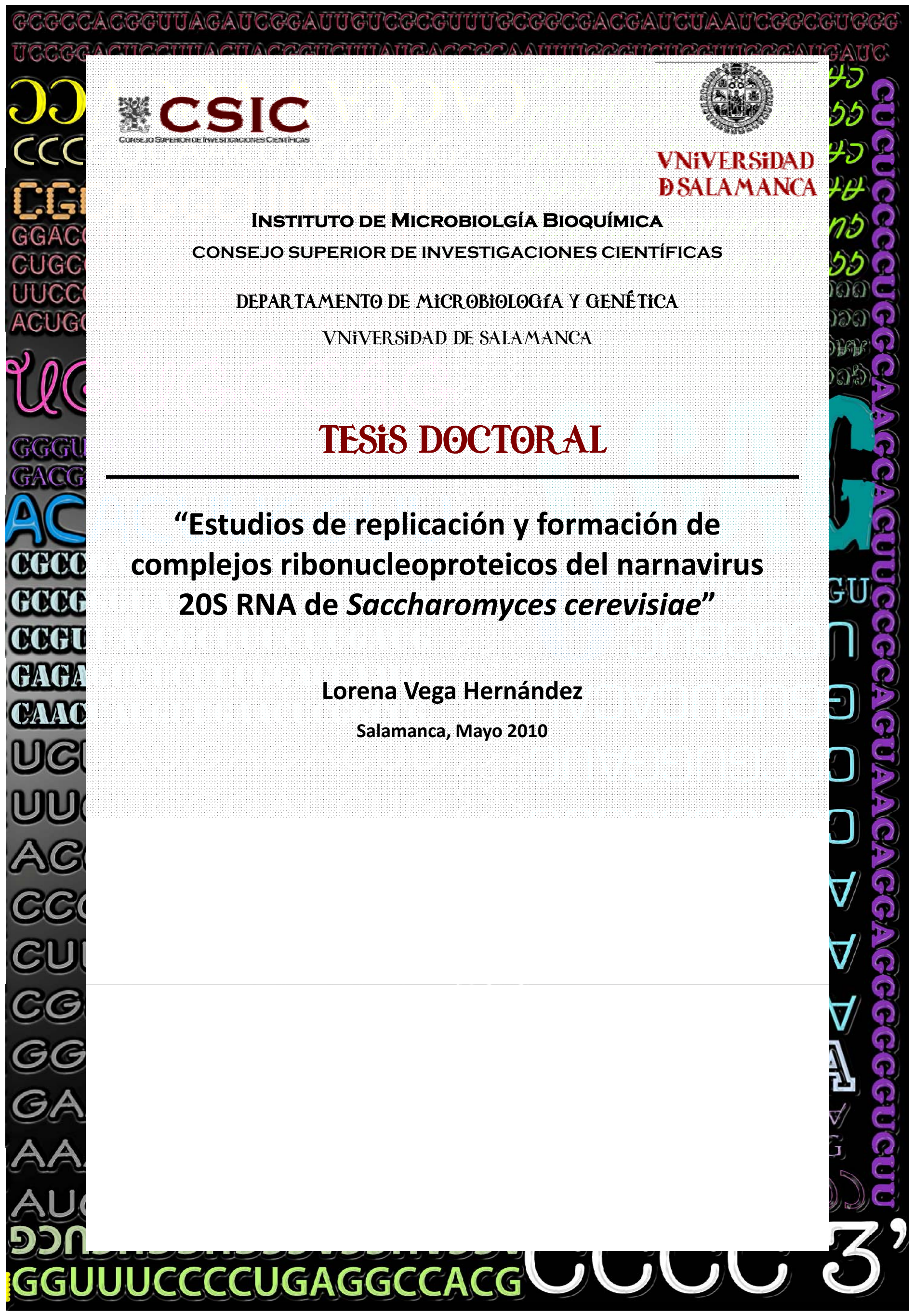


INSTITUTO DE MICROBIOLGÍA BIOQUÍMICA

CONSEJO SUPERIOR DE INVESTIGACIONES CIENTÍFICAS

DEPARTAMENTO DE MICROBiOLOGIA Y GENETTiCA

VNIVER SIDAD DE SALAMANCA

\section{TESÍS DOCTORAL}

"Estudios de replicación y formación de complejos ribonucleoproteicos del

narnavirus 20S RNA de Saccharomyces

cerevisiae"

Memoria presentada por Lorena Vega Hernández para optar al grado de Doctor en Bioquímica 


\section{DR. ÁNGEL DOMÍNGUEZ OLAVARRI, CATEDRÁTICO DE MICROBIOLOGÍA Y DIRECTOR DEL DEPARTAMENTO DE MICROBIOLOGÍA Y GENÉTICA DE LA UNIVERSIDAD DE SALAMANCA,}

\section{CERTIFICA:}

Que la memoria titulada "Estudios de replicación y formación de complejos ribonucleoproteicos del narnavirus 20S RNA de Saccharomyces cerevisiae", presentada por la licenciada Lorena Vega Hernández, para optar al Grado de Doctor en Bioquímica, ha sido realizada bajo la dirección de la Dra. Mạ Rosa Esteban Cañibano y el Dr. Tsutomu Fujimura en el Instituto de Microbiología Bioquímica, centro mixto de la Universidad de Salamanca (Departamento de Microbiología y Genética) y el Consejo Superior de Investigaciones Científicas.

Y para autorizar su presentación y evaluación por el tribunal correspondiente, firmo el presente certificado en Salamanca a de Abril de 2010.

Fdo. Dr. Ángel Domínguez Olavarri 
DRA. Ma ROSA ESTEBAN CAÑIBANO, PROFESOR DE INVESTIGACIÓN DEL CONSEJO SUPERIOR DE INVESTIGACIONES CIENTÍFICAS Y EL DR. TSUTOMU FUJIMURA, INVESTIGADOR CONTRATADO DEL CONSEJO SUPERIOR DE INVESTIGACIONES CIENTÍFICAS, MIEMBROS DEL INSTITUTO DE MICROBIOLOGÍA BIOQUÍMICA,

\section{CERTIFICAN:}

Que la licenciada Lorena Vega Hernández ha realizado el trabajo titulado "Estudios de replicación y formación de complejos ribonucleoproteicos del narnavirus 20S RNA de Saccharomyces cerevisiae", bajo su dirección, en el Instituto de Microbiología Bioquímica, centro mixto de la Universidad de Salamanca (Departamento de Microbiología y Genética) y el Consejo Superior de Investigaciones Científicas.

Y para autorizar su presentación y evaluación por el tribunal correspondiente, firmo el presente certificado en Salamanca a _ de Abril de 2010. 
A mi familia, por su confianza infinita

A Ángel, mi constante 
Este trabajo se ha realizado gracias a la beca predoctoral de Formación de Personal Investigador (FPI) adscrita al proyecto BFU2004-00373 del Ministerio de Educación y Ciencia, "Estudios de replicaión y persistencia viral de los narnavirus 235 RNA y 20 S RNA de levaduras usando genética reversa".

Me gusta mucho viajar.

Hace ya algunos años emprendí un sorprendente viaje que me ha servido para madurar y crecer como persona. En este recorrido ha habido días de tormentas y temporal, pero compensado con creces por los días en los que salía el sol. El viaje ha sido largo, pero finalmente llega a su destino. Afortunadamente no he hecho sola el camino, siempre he estado acompañada y respaldada por personas increíbles que siempre me han ofrecido su apoyo y ayuda.

Mis directores y capitanes del barco: Rosa es personal y científicamente una maestra cuyo trato siempre va más allá que el estrictamente profesional. Se trabaja con más ilusión viendo cada día a una persona que disfruta de su trabajo cada segundo y se emociona con cada resultado. Gracias por enseñarme, cuidarme y mostrarme el mundo de la investigación con esa pasión arrolladora. Siento si a veces te he dejado un poco ciega con "mis colorines", pero soy incapaz de ver las cosas en blanco y negro!!

Fujimura,私は各実験から考え教えていただき、心からありがとうございます. Thank you for show me the reason of each experiment and the importance of thinking in each step of the way.

Gracias a mis compañeros en el barco:

Nieves, constante en tu búsqueda de narnavirus más allá de Saccharomyces, siempre optimista y alegre. Pilar, gracias por tu gran ayuda, dispuesta a echar una mano y a aprender somos muy afortunados en la celda 227 al contar con tu vitalidad y esas manos mágicas. Ha sido un placer trabajar contigo. Manu, para ti ahora también se acerca el invierno, pero acaba pasando en los reinos de poniente, el Muro aguantará. Continúa el legado de "Los virus de Narnia", aunque sea con $23 \mathrm{~S}$ RNA ;-).

Dirigiendo a toda la tripulación, gracias a Ángel Durán por intentar coordinar con una paciencia infinita todo y a todos. A pesar de lo difícil que es tenernos a todos contentos, has conseguido que el IMB funcione. Espero que siga todo igual o mejor en el IMBFG.

Las cosas no avanzan si a tu lado no están los técnicos que te hacen la vida más fácil. Gracias a Manolo por ofrecer siempre una sonrisa y por las más de 1500 secuencias que te he mandado durante estos años! Gracias Alegría, Paco Soriano y Miguel, por vuestra eficiencia en el trabajo. Especialmente quiero dar mil millones de gracias (o más) a Paco Alonso, eres el mejor! Gracias por tu eficacia, tu disponibilidad, por hacer que todo funcione... no sabes cuánto te voy a echar de menos! 
Este viaje tuvo una parada en Heidelberg, donde tengo que agradecer al Dr. Ed Hurt y a todo su equipo la hospitalidad con la que me acogieron. Especialmente gracias a Brigitte, Andrea, Franzi y Cathy.

Pero sin buenos compañeros y amigos que te ayuden, las fuerzas flaquean y el barco se hunde.

Laura, mi neoyorquina, me guiaste y animaste la primera, fuiste mi becaria senior. Me ayudaste cuando todo era caos e incertidumbre, gracias por enseñarme a buscar la luz!

Las más importantes, Abiwyn y Patriwel. Trabajo, convivencia, amistad... ay madre, cuántas cosas hemos vivido y lo que nos hemos reído (qué fuerte qué fuerte qué fuerte!!). Ha sido intenso, eh? Las tertulias de los domingos por la mañana, jugar al Farenheit y al Padrino... Muchísimas gracias por haberme acompañado casi cada día en este viaje.

Pero cuando el "poder de tres" se disolvió, encontré un gran lugar donde reírme, relajarme y por supuesto, tomar café (y croqueta)... iiEl Club de fans de la Madre de Charo!! Alberto, pide ayuda profesional, Las Señoras acabarán contigo! Gracias por los viajes a la nieve, tu buen humor y alegría en todo lo que haces. You've been a very bad girl, a very, very, bad, bad girl, Gaga. Carl(it)o(s), que no haya montaña que no puedas escalar, Bruce (brought on the wind) te ayudará, seguro. José, Gracias por tu serenidad cuando alrededor todo es un poco caótico, me alegra mucho haber conocido al José no-trabajador. Raúl, gracias por cuidar de mí, y dejarme devorar tus libros! (Ya sabes, viva Jaime Lannister!). Sigue practicando con la repostería, pero... redecilla! Miguel, haz que el resto de los fans escuchen buena música, que lo den todo saltando en el Tum tum!! Siempre nos quedarán Tontili y Monguili. Sofía, dicen por ahí que eres "mini-yo", pero creo que eres la versión hipermejorada! No dejes de sonreir!!

Los que empiezan el viaje, los que están a punto de acabarlo, y los que hace tiempo que despegaron, gracias!! Ana (compañera de biblioteca en la recta final), Jorge (mi pequeño Padawan, qué buenos momentos en prácticas y con el Guitar Hero!), Belinda, Talía (imira cómo viola! Cada vez que como maaaacarrones me acuerdo de tí), Sergio, Pedro, Marisa, Pepín, Toñi (qué gran día zamorano! El año que viene repetimos. Espero que el mandala me de suerte!), Mario (con lo tranquilo que eres vas a ser de los pocos madrileños no-estresados), Elisa, Naza, Mariona, Ester, Paco, David... En definitiva, todos los becarios/contratados del IMB, me habéis hecho disfrutar del "mundo-pasillo", y cómo no, de las cenas!! Por supuesto gracias a los bingueros por ese momento "iilineaaaaa!!".

Mil gracias a mis compañeros de batalla fuera del laboratorio pero en de los "sitios de ocio": Paco, cada vez falta menos para que defiendas nuestras calles, mantente firme que sino Abi te lía! Isa, la profe fashion, mucha suerte en Londres, prometo visitarte. Rosario y Adrián, con sus ojitos de pez rumbo a los USA? Y por supuesto Javi, mi compañero y amigo en la biblioteca durante toda la escritura de este libro. Gracias por sobornarme en su día con bombones!! Qué grandes las reuniones marujiles con las compis de doctorado! No quiero olvidarme de Chus, Vir y mi roomie, Elvira, la reina del dancing! Cómo nos lo hemos pasado todos estos años, eh? 
Tampoco puedo olvidarme de INNOVA-Salamanca, de todos los que conforman la asociación y han luchado para que los jóvenes investigadores tengamos derechos y seamos considerados como lo que realmente somos: trabajadores.

Gracias a las personas que han tenido que ver en quién me he convertido hoy: Alexis, mi sensei y eurofan, sacaste lo mejor de mí y me demostraste que todo llega. Gracias por hacerme reír, llorar y por supuesto bailar! Rafa, por aguantar la compostura entre tanto biólogo-bioquímico. Gracias por ser nuestra RAE particular. Peri, eres una persona tan segura de sí misma que creo que naciste siendo Akela! Gracias por descubrirme el rol, los comics, el Señor de los Anillos, y todo eso por lo que el resto de mis amigos me señalan y me llaman friki. Soraya, Pipistrellus, pequeña criatura... la esencia más pura va en frasco pequeño. David, algo así eres tú, tuuuuuuuu. Te admiro mucho, espero no perder nunca tu estela. Siempre nos quedará Mocedades. Aida, lo sé, cuando nos juntamos todos parece un aquelarre, pero en el fondo somos buenas personas. Santa paciencia la que tienes ... Belén, muta sésil... no puedo (ni quiero) olvidarme de todo lo que hemos vivido. Quién iba a decir que serías la primera en abandonar el trofeo lamprea...

Gracias a todos los que en alguna ocasión han mostrado interés en saber lo que hacía aunque, seamos sinceros, nunca lo habéis entendido (pero me hacía ilusión, que conste).

Mis amigas de Ponferrada (y sus consortes): Ana y Edu por vuestra hospitalidad, Bea, mi PAT-socia y cinéfila extrema, Brenda y Jorge por descubrirme el maravilloso mundo Nespresso. Mariajo, gracias porque aunque nos veamos muy muy poco, sé que siempre estás ahí y nuestros reencuentros siempre son memorables. Silvia y Miki, por vuestro amor por la montaña, el trabajo y porque sé que siempre puedo contar con vosotros. Sole, Zaira, Toni y el pequeño berciano-mallorquín que está en camino, gracias por esos días en Palma! A los apaños del mundo, "el Rey y el Roi", porque sois muy majetones!! Gracias también a mis amigas talaveranas. Gracias Patricia por mostrarme el mundo de John Boy!

Aunque no sepan a qué me he estado dedicando estos años, siempre me han apoyado porque confían en mí. Gracias a mi padre por tener guardado en la cartera el título de mi proyecto de tesis desde hace cinco años, a mi madre por su generosidad en todo e intentar cuidar de mi en la distancia! A mis hermanas, las mejores. Aida, a reina da xustiza galega. Sei que sempre podo contar contigo!! Berta, tienes un corazón que no te cabe en el pecho de lo buenaza que eres. Muchísimas gracias por dejar que el peugi haya pasado tanto tiempo conmigo. No te imaginas lo mucho que me ha ayudado. Sin duda alguna, la envidia de todos los coches.

Y a Ángel le tengo que agradecer tanto que me llevaría otra tesis escribirlo!! Gracias por mantenerme a flote cuando creía ahogarme, por ser paciente, sincero y optimista. Because maybe, you're gonna be the one that saves me. And after all, you're my wonderwall.

Esta etapa del viaje ha llegado a su fin. Lista y ansiosa de continuar viajando... 
[...] Tell me your secrets and ask me your questions Oh, let's go back to the start

Running in circles Coming up tails Heads on the science apart

Nobody said it was easy It's such a shame for us to part Nobody said it was easy No one ever said it would be so hard

Oh take me back to the start [...] 


\section{ABREVIATURAS}

\begin{tabular}{|c|c|}
\hline ABREVIATURA EMPLEADA & SIGNIFICADO \\
\hline aa & Aminoácido \\
\hline ATP & Adenosín trifosfato \\
\hline bp & base pairs: pares de bases \\
\hline BSA & Seroalbúmina bovina \\
\hline CAPS & Ácido 3-(ciclohexilamino)-1-propanesulfónico \\
\hline cDNA & DNA complementario \\
\hline $\mathbf{C i}$ & Curio \\
\hline cpm & Cuentas por minuto \\
\hline CTP & Citosín trifosfato \\
\hline DNA & Ácido desoxirribonucleico (ADN) \\
\hline DNAsa & Desoxirribonucleasa \\
\hline ds-... & ... bicatenario (DNA o RNA) \\
\hline DTT & Ditiotreitol \\
\hline EDTA & Ácido etilendiaminotetraacético \\
\hline et al. & et alii (del latín "y otros") \\
\hline Fig. & Figura \\
\hline$g$ & Aceleración de la gravedad \\
\hline GTP & Guanosín trifosfato \\
\hline h. & Horas \\
\hline IPTG & Isopropil- $\beta$-D-tiogalactósido \\
\hline kan & Kanamicina \\
\hline kb & Kilobase(s) \\
\hline kDa & Kilodalton(s) \\
\hline $\min$. & Minutos \\
\hline nt & Nucleótido(s) \\
\hline NTP & Nucleótido trifosfato \\
\hline ORF & Open reading frame: fase de lectura abierta \\
\hline
\end{tabular}




\begin{tabular}{|c|c|}
\hline PABA & Ácido 4-aminobenzoico \\
\hline PCR & $\begin{array}{l}\text { Polymerase chain reaction: Reacción en } \\
\text { cadena de la polimerasa }\end{array}$ \\
\hline $\operatorname{RdRp}$ & $\begin{array}{l}\text { RNA polymerase RNA dependent: RNA } \\
\text { polimerasa dependiente de RNA }\end{array}$ \\
\hline RNA & Ácido ribonucleico (ARN) \\
\hline RNAsa & Ribonucleasa \\
\hline rpm & revoluciones por minuto \\
\hline rRNA & RNA ribosomal \\
\hline SDS & Laurilsulfatosódico \\
\hline seg. & Segundo (s) \\
\hline ss-... & ... monocatenario (DNA o RNA) \\
\hline SSC & Sodio salino citrato \\
\hline TCA & Ácido tricloroacético \\
\hline TE & Tris-EDTA \\
\hline Tris & Tris(hidroximetil)aminometano \\
\hline tRNA & RNA de transferencia \\
\hline TTP & Timidín trifosfato \\
\hline U & Unidad de actividad enzimática \\
\hline ufp & Unidades formadoras de placas \\
\hline UTP & Uridín trifosfato \\
\hline
\end{tabular}

En la redacción de esta memoria se han empleado diversos anglicismos y palabras en inglés para referirse a ciertos compuestos y moléculas. Hemos considerado oportuno su uso debido a que en el lenguaje científico no son imprescindibles las traducciones literales, sino la comprensión del significado del término, sea cual fuere su idioma. 


\section{ÍNDICE}

\section{INTRODUCCIÓN}

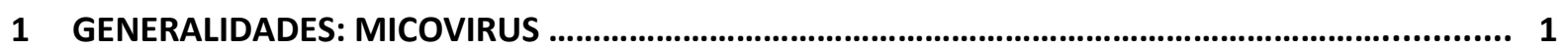

1.1 Características generales de los micovirus ....................................................................... 1

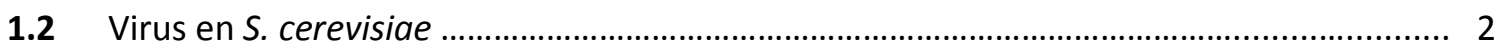

1.2.1 Virus con genoma dsRNA ......................................................................................... 3

* Virus L-A

* Virus L-BC

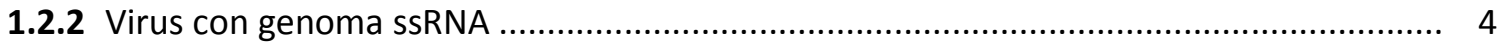

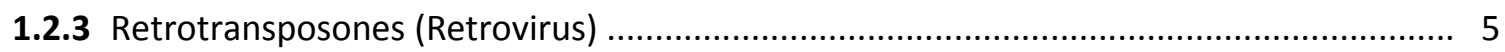

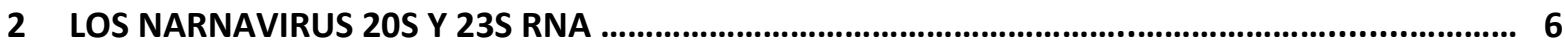

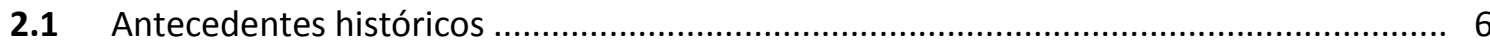

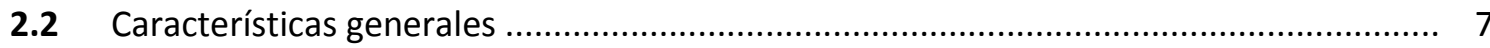

* El genoma

* La polimerasa

3 LOS COMPLEJOS RIBONUCLEOPROTEICOS COMO UNIDAD VIRAL ........................................ 10

3.1 Características y tipos de complejos virales ............................................................... 10

* Localización y estequiometría

* Tipos de complejos

4 REPLICACIÓN DE 20S RNA

4.1 Replicación de virus con genoma RNA monocatenario de polaridad positiva ............... 12

4.1.1 Replicación de los virus 20S RNA y 23S RNA …........................................................ 13

4.2 Replicación de virus con genoma RNA bicatenario .................................................... 14

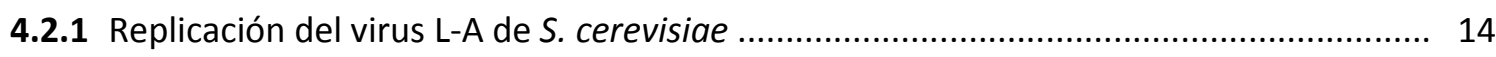

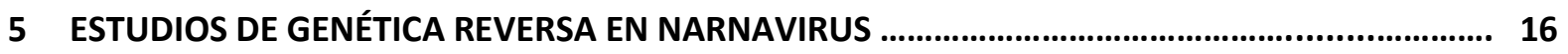

5.1 Generación de 23S RNA a partir de un vector de expresión .......................................... 16

5.2 Resumen de los resultados sobre la replicación de 23S RNA ....................................... 18

6 SISTEMAS DE DEGRADACIÓN DE mRNAs EN EL CITOPLASMA DE S. cerevisiae ....................... 19

6.1 Decapping dependiente de desadenilación ................................................................... 19 


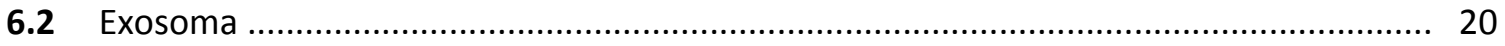

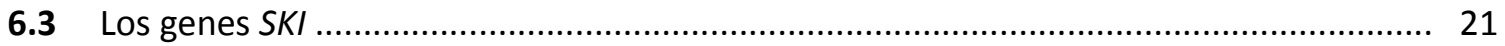

* XRN1/SKI1

* $S K I 2$

\section{MATERIALES Y MÉTODOS}

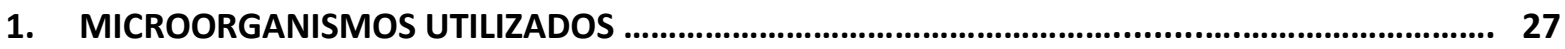

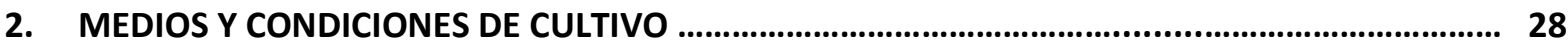

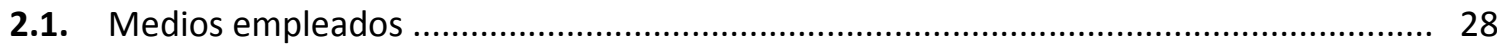

2.1.1. Medios de cultivo para S. cerevisiae ......................................................................... 28

2.1.2. Medios de cultivo para E. coli ................................................................................. 29

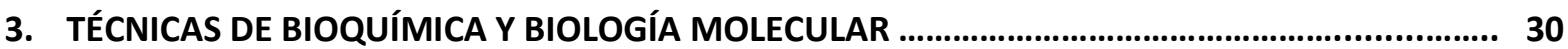

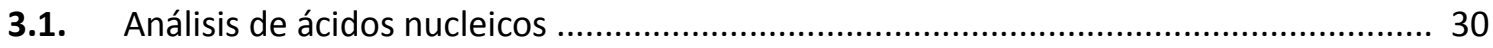

3.1.1. Obtención de DNA plasmídico .......................................................................... 30

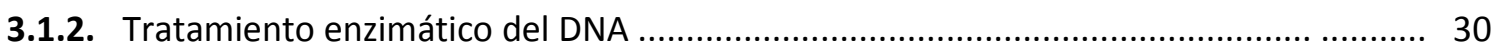

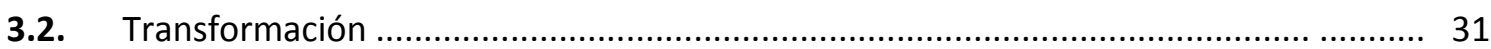

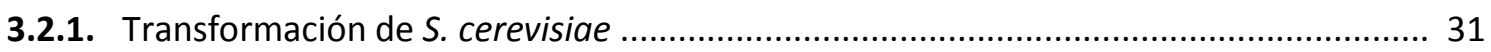

3.2.2. Transformación de E. coli ................................................................................. 32

3.3. Reacción en cadena de la polimerasa (PCR) …..................................................... 32

* RT-PCR

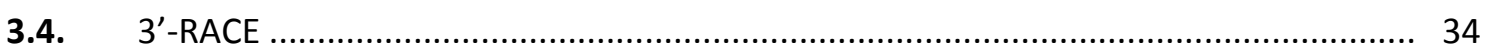

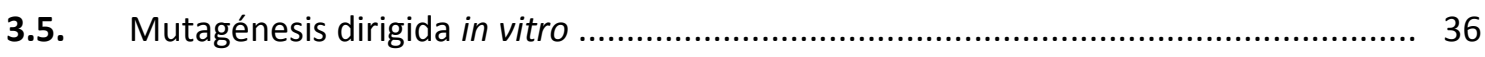

3.6. Subclonación de fragmentos de DNA …............................................................ 38

3.7. Secuenciación de ácidos nucleicos ....................................................................... 38

3.8. Extracción y concentración de RNAs .................................................................. 38

3.8.1. Análisis de 20S RNA en S. cerevisiae: condiciones experimentales ........................... 38

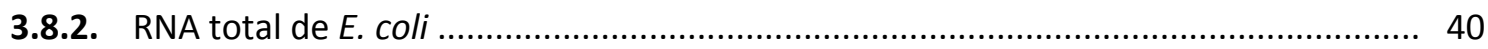

3.9. Sistemas electroforéticos para el análisis de ácidos nucleicos .................................. 40

3.10. Hibridación de ácidos nucleicos: detección de RNA (Northern Blot) ......................... 40

3.11. Análisis de proteínas ........................................................................................ 41

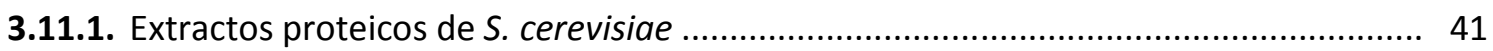

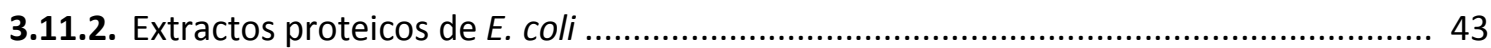


3.12. Sistemas electroforéticos para el análisis de proteínas 43

3.12.1. Tinción de geles de acrilamida

* Tinción con azul coomassie

* Tinción con plata

3.12.2. Western Blot 44

3.13. Purificación parcial de complejos ribonucleoproteicos p91/20S RNA ......................... 45

3.14. Gradientes continuos de glicerol ............................................................................. 45

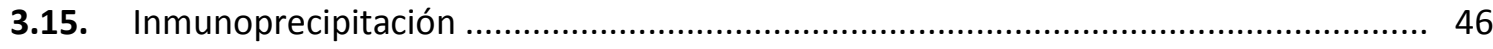

* Detección de 20S RNA

* Detección de proteínas

3.16. Enriquecimiento de complejos con anticuerpos anti-GFP conjugados ...................... 48

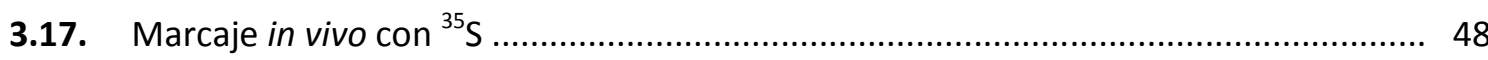

3.18. Expresión de RNA y proteínas en E. coli …............................................................... 49

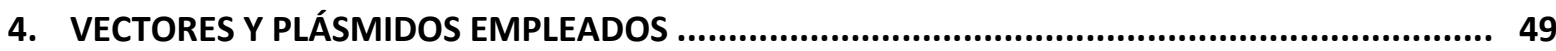

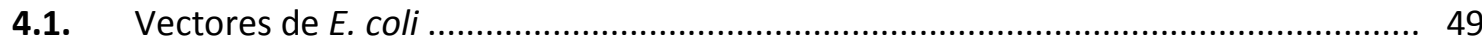

* pBluescript KS+

* pLM62+

4.2. Vectores de S. cerevisiae

50

$$
\begin{aligned}
& * \mathrm{pl} 2 \\
& * \mathrm{p} 375 \\
& \text { * pALI23 } \\
& \text { * pRS313 }
\end{aligned}
$$

5. MÉTODOS GENÉTICOS

5.1. Aislamiento de ascosporas mediante micromanipulación: análisis de tétradas

5.2. Citoducción

6. ANÁLISIS BIOINFORMÁTICO DE DATOS

\section{RESULTADOS}

GENERACIÓN DE 20S RNA EN S. cerevisiae A PARTIR DE UN VECTOR DE EXPRESIÓN

1 ESTUDIO dE LAS SEÑALES EN cis EN EL EXTREMO 3' QUE AFECTAN A LA REPLICACIÓN Y FORMACIÓN DE COMPLEJOS p91/20S RNA

1.1 Estudios de replicación de la cadena (+)

1.1.1 Modificación de las cuatro últimas bases ............................................................... 57

1.1.2 Efecto de la adición o eliminación de bases en el extremo $3^{\prime}$................................... 58 
1.1.3 Modificación de la estructura secundaria ................................................ 59

* Importancia de la quinta guanina

* Otras modificaciones en el extremo 3' de 20S RNA

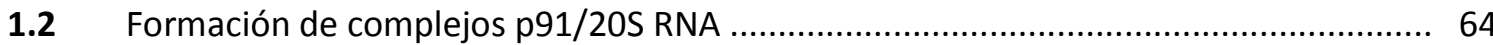

1.2.1 Efecto de las modificaciones de las últimas cuatro citosinas ...............................65

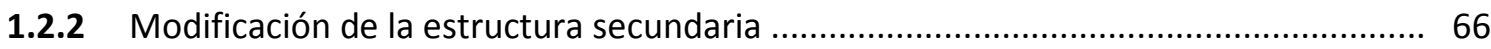

1.3 Generación de 20S RNA a partir de cadenas de polaridad negativa ........................ 67

1.3.1 Efecto de modificaciones del extremo 3' de la cadena (-) sobre la replicación de 20S

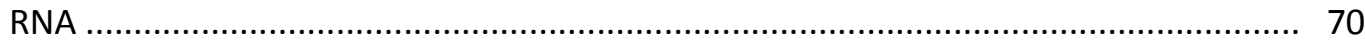

Otras modificaciones en el extremo 3' de la cadena (-) de 20S RNA

2 EFECTO DE LOS SISTEMAS DE DEGRADACIÓN DE mRNAs DE S. cerevisiae EN LA GENERACIÓN Y

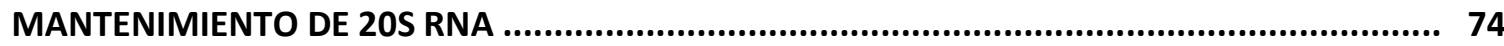

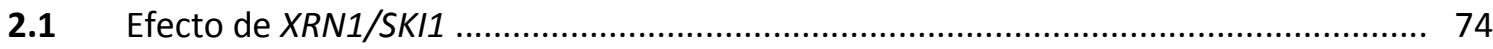

2.1.1 Efecto de XRN1/SKI1 en el mantenimiento de 20S RNA ................................... 75

* Citodución

Segregación de 20S RNA a partir de un diploide heterozigótico XRN1/XRN1A

2.1.2 Efecto de XRN1/SKI1 en la generación de 20S RNA ....................................... 76

2.1.3 Efecto de XRN1/SKI1 sobre otros virus de $S$. cerevisiae ..................................... 78

2.2 Efecto del exosoma ............................................................................. 80

\section{IDENTIFICACIÓN DE POSIBLES FACTORES DEL HOSPEDADOR FORMANDO PARTE DE LOS} COMPLEJOS p91/20S RNA 81

3.1 Intentos de purificación de los complejos p91/20S RNA ................................... 81

3.2 Estudios de las proteínas presentes en los complejos ....................................... 85

3.2.1 Inmunoprecipitación con anticuerpos anti-p91 ............................................ 85

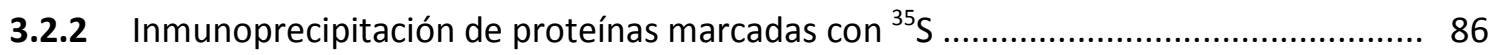

3.2.3 Análisis de los complejos p91-GFP/20S RNA utilizando anticuerpos anti-GFP .......... 87

3.3 Formación de complejos p91/20S RNA en un sistema heterólogo: E. coli ................. 89

3.3.1 Expresión de 20S RNA y p91 en E. coli .......................................................... 89

3.3.2 20S RNA y p91 cosedimentan en E. coli ....................................................... 90

3.3.3 Inmunoprecipitación de los complejos p91/20S RNA en $E$. coli ............................... 92

La formación de los complejos es específica: mutaciones en el RNA y la proteína 20S RNA no se replica en E. coli

Diferencias en la cantidad de complejos p91/20S RNA en S. cerevisiae y en E. coli 


\section{DISCUSIÓN}

1. ESTUDIO DE SEÑALES EN CiS QUE AFECTAN A LA REPLICACIÓN Y FORMACIÓN DE COMPLEJOS

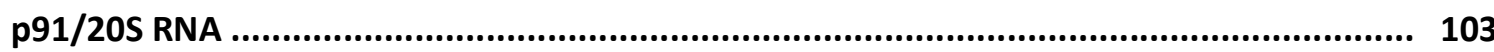

2. EFECTO DE LA EXONUCLEASA XRN1/SKI1 SOBRE LA GENERACIÓN Y MANTENIMIENTO DE 20S RNA

3. LOS COMPLEJOS RIBONUCLEOPROTEICOS $p 91 / 20 S$ RNA EN REPOSO NO NECESITAN FACTORES DEL HOSPEDADOR

CONCLUSIONES

ANEXOS

I. TABLAS

II. PUBLICACIONES

BIBLIOGRAFÍA 


\section{INTRODUCCIÓN}

"El misterio es la cosa más bonita que podemos experimentar. Es la fuente de todo arte y ciencia verdaderos"

ALBERT EINSTEIN 


\section{GENERALIDADES: MICOVIRUS}

Micovirus: virus que infectan hongos

(Hollings, 1962)

Los micovirus infectan hongos tanto unicelulares como filamentosos. Entre ellos podemos encontrar gran variedad de los genomas virales presentes en la naturaleza (retrovirus, RNA mono y bicatenario). Son sistemas de una alta simplicidad, lo que hace que algunos de estos virus estén bien caracterizados.

Su característica principal es la de tener un ciclo de vida intracelular. Estos virus han eliminado su ciclo lítico (o etapa extracelular) comportándose como parásitos intracelulares obligatorios, lo que hace que su presencia pase normalmente desapercibida. De hecho, no fue hasta los años 60 cuando se descubrió este tipo de virus. Se cree que la ausencia de rutas extracelulares de trasmisión puede ser debida a la facilidad que tienen para pasar de una célula a otra mediante los procesos normales de intercambio de información genética en hongos, como la fusión de hifas (o anastomosis) o mediante conjugación entre grupos genéticamente diferentes y compatibles.

\subsection{CARACTERÍSTICAS GENERALES DE LOS MICOVIRUS}

La mayor parte poseen genoma RNA bicatenario (dsRNA) encapsidado en partículas isométricas de $25-50 \mathrm{~nm}$ de diámetro.

Las infecciones causadas por micovirus se caracterizan por ser latentes y persistentes. La latencia beneficia a la supervivencia del hospedador, mientras que la persistencia beneficia al virus, que carece de infectividad.

Los virus de hongos parecen haber coevolucionado con sus hospedadores, ya que algunos micovirus pueden conferir alguna ventaja adaptativa a su hospedador (Ej. Fenotipo killer en levaduras).

Aunque la mayoría de los micovirus no producen un efecto deletéreo (son avirulentos), se han descrito casos en los que el metabolismo del hospedador se puede ver afectado. Así, algunos 
micovirus causan fenómenos de hiper o hipovirulencia a los hongos que infectan (Ej. el Virus NB631 de Cryphonectria parasitica).

Se han descrito cuatro familias de micovirus: Hypoviridae, Partitiviridae, Totiviridae y Narnaviridae. Las dos últimas familias se detallan en el siguiente apartado. En la figura 1 se muestra un dendograma con la relación filogenética de varios de los micovirus comparando las RNA polimerasas dependientes de RNA codificadas en sus genomas. Se incluyen también los fagos RNA de la familia Leviviridae, ya que filogenéticamente están muy próximos a los virus de la familia Narnaviridae.

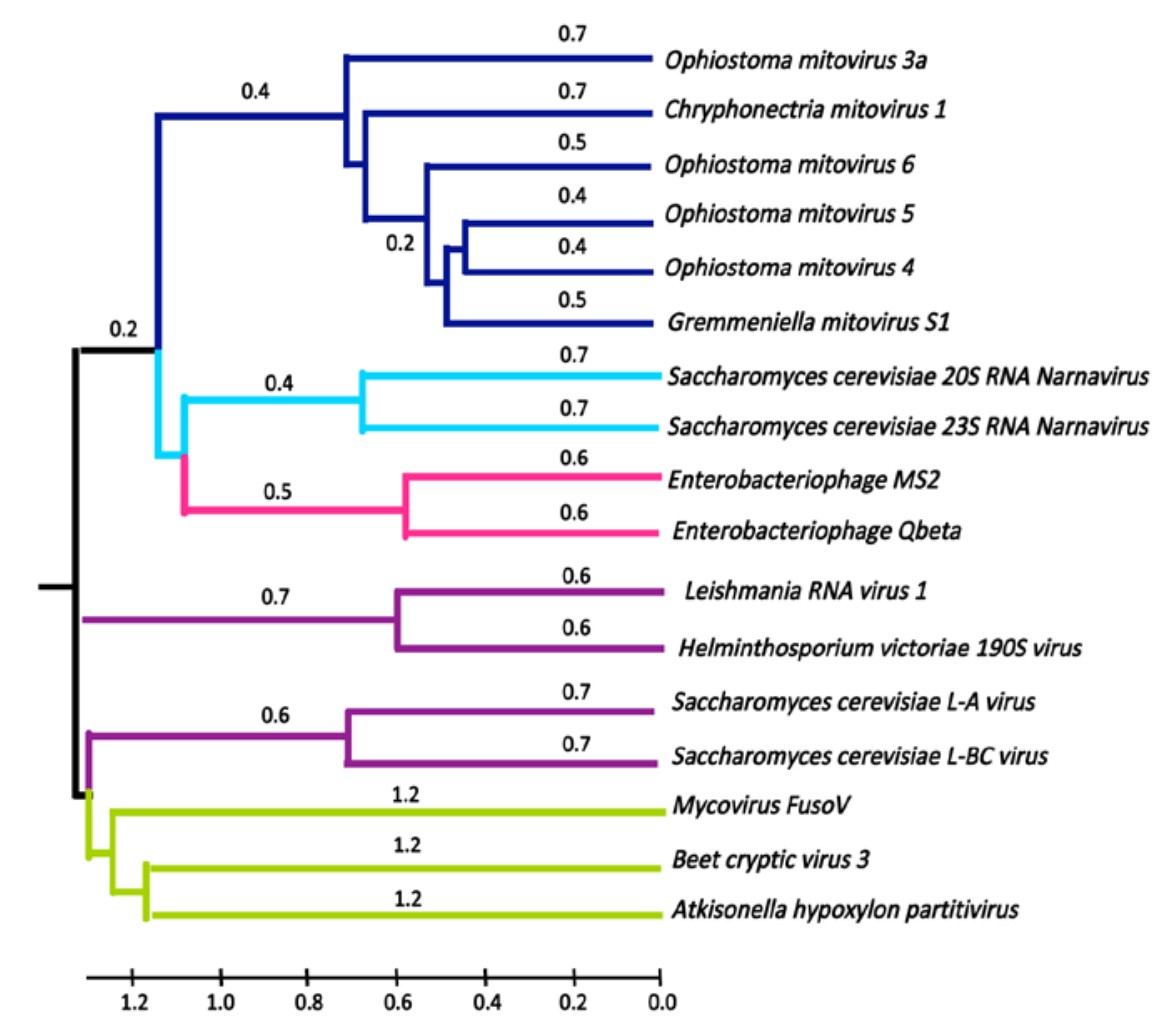

Narnaviridae

Leviviridae

Totiviridae

Partitiviridae

Figura 1. Dendrograma realizado a partir de las RNAs polimerasas dependientes de RNA de algunos micovirus. Se incluyen también algunos colifagos de la familia Leviviridae.

\subsection{VIRUS EN S. cerevisiae}

Este trabajo se ha llevado a cabo con la levadura S. cerevisiae. En ella pueden existir varios tipos de virus con genoma RNA que se recogen en la Tabla 1. 
TABLA 1. Virus presentes en la levadura S. cerevisiae

\begin{tabular}{|c|c|c|}
\hline Nombre & Tamaño (kb) & Proteínas codificadas \\
\hline \multicolumn{3}{|c|}{ Genoma dsRNA } \\
\hline L-A & 4.6 & $\begin{array}{l}\text { Proteína mayoritaria de la cápsida Gag (76 kDa). } \\
\text { Proteína minoritaria de la cápsida Gag-Pol (170 kDa: RNA } \\
\text { polimerasa). }\end{array}$ \\
\hline M1,M2...M28 & $1.8-2.0$ & Proteína precursora de las toxinas killer. \\
\hline L-BC & 4.6 & Proteínas mayoritarias de la cápsida: 77 kDa y 73 kDa. \\
\hline \multicolumn{3}{|c|}{ Genoma ssRNA } \\
\hline $\begin{array}{l}\text { 20S RNA } \\
23 S \text { RNA }\end{array}$ & 2.5 & $\begin{array}{l}\text { RNA polimerasa dependiente de RNA, p91 (91 kDa). } \\
\text { RNA polimerasa dependiente de RNA, p104 (104 kDa). }\end{array}$ \\
\hline \multicolumn{3}{|c|}{ Retrovirus (Retrotransposones) } \\
\hline $\mathrm{Ty}_{1}, \mathrm{Ty}_{2} \ldots \mathrm{Ty}_{5}$ & 5.9 & $\begin{array}{l}\text { TYA: precursor de las proteínas mayoritarias de la cápsida. } \\
\text { TYA-TYB (Gag-Pol, proteína de fusión): precursor de proteasa, } \\
\text { integrasa, transcriptasa reversa y RNAsa H. }\end{array}$ \\
\hline
\end{tabular}

\subsubsection{VIRUS CON GENOMA dSRNA}

Los virus presentes en la levadura con este genoma pertenecen a la familia Totiviridae.

\section{VIRUS L-A}

El virus L-A es la especie tipo de la familia. Este virus está presente en la gran mayoría de cepas de $S$. cerevisiae. El genoma tiene una única molécula de RNA de $4.6 \mathrm{~kb}$ que se encuentra encapsidada en una partícula icosaédrica de $39 \mathrm{~nm}$. Este RNA codifica dos proteínas, la proteína mayoritaria de la cápsida (Gag) de 76 kDa y una proteína de fusión, Gag-Pol, con actividad RNA polimerasa, de $170 \mathrm{kDa}$. Su ciclo de replicación es el típico para virus con genoma dsRNA, como se puede ver en el apartado 4.2 .

Algunas cepas de la levadura secretan una proteína letal para otras (toxina killer), pero a la que es inmune la cepa productora. Esta proteína está codificada en un dsRNA satélite del virus L-A, llamado $M$. Existen diferentes variedades de $M\left(M_{1}, M_{2}, \ldots M_{28}\right)$ dependiendo de la cepa (Wickner, 1996; Knipe, 2006). 


\section{VIRUS L-BC}

Este virus está mucho menos estudiado que el virus L-A. Frecuentemente lo acompaña en la misma cepa, pero con una cantidad de viriones inferior, aproximadamente unas diez veces. La secuencia de este virus muestra similitud con L-A, especialmente en los dominios consenso de su polimerasa (Bruenn, 1993; Wickner, 1996).

\subsubsection{VIRUS CON GENOMA sSRNA}

A este grupo pertenecen los virus del género Narnavirus de la familia Narnaviridae. Este género da nombre a la familia, y ha sido el más estudiado durante los últimos años, especialmente en el laboratorio en el que se ha desarrollado este trabajo.

La familia está formada por micovirus con genoma RNA monocatenario lineal de polaridad positiva ((+)-ssRNA). El tamaño del genoma es relativamente pequeño, entre 2 y $3 \mathrm{~kb}$, y codifica sólo una proteína, su RNA polimerasa dependiente de RNA (RdRp, del inglés RNA dependent RNA polymerase). Lo más destacable de este grupo es que no codifican proteínas de la cápsida. El hecho de carecer de cápsida proteica hizo que hasta el año 2000 estos virus no fueran considerados como tales, a pesar de replicarse y tener características comunes a otros virus RNA (van Regenmortel, 2000). El nombre de la familia, Narnaviridae, proviene de $\underline{\text { Nacked }}$ RNA virus (virus RNA desnudos). Aunque estos virus carecen de cápsida proteica, no se encuentran desprotegidos en el citoplasma, ya que los genomas se asocian con sus RdRp respectivas formando complejos ribonucleoproteicos, como se detallará en el apartado 3.

Los narnavirus de S. cerevisiae son los siguientes:

ScNV-20S: Saccharomyces narnavirus 20S RNA

ScNV-23S: Saccharomyces narnavirus 23S RNA

Este trabajo se ha desarrollado con el virus ScNV-20S, al que a partir de ahora designaré como 20 S RNA. Se encuentra en la mayor parte de cepas de laboratorio de S. cerevisiae y ha sido el más estudiado.

Recientemente se ha descrito otro virus que podría pertenecer al género Narnavirus. Se trata de Phytophtora infestans RNA virus 4 (PiRV-4). Este virus infecta el oomiceto P. infestans, causante de la hambruna irlandesa de la patata (Fry, 1997). Aunque este virus todavía no está aceptado por el International Committee o Taxonomy of Viruses (ICTV) como miembro de la familia 
Narnaviridae, tiene características muy similares al virus 20S RNA (Cai et al., 2009; Smith-Vikos, 2009).

En la familia Narnaviridae, además del género Narnavirus, existe el género Mitovirus. Estos virus no infectan S. cerevisiae, pero sí a otros ascomicetos. Este género se denomina Mitovirus porque los virus que lo componen se localizan en las mitocondrias del hospedador. Una de las características más importantes de este género es que muchos de los ascomicetos infectados por ellos tienen importancia agrícola, ya que causan enfermedades en las plantas infectadas y a veces, la presencia de estos virus provoca cambios en la patogenicidad del hongo, dando lugar a fenómenos de hiper- o hipovirulencia. Los mitovirus están ampliamente distribuidos en la naturaleza, y se pueden encontrar en hongos que infectan castaños (Cryphonectria parasitica), olmos (Ophiostoma novo-ulmi), patatas (Rhizoctonia solani) y abetos (Gremmeniella abietina). Actualmente existen 5 especies de mitovirus aceptadas por el International Committee on Taxonomy of Viruses (ICTV) (Fauquet, 2005).

\subsubsection{RETROTRANSPOSONES (RETROVIRUS)}

Los retroelementos (retrovirus, retrotransposones y retrointrones) son moléculas que utilizan la transcriptasa reversa para su propagación en la célula. En $S$. cerevisiae existen cinco retrovirus Ty1 - Ty5 (Transposon yeast). Estas partículas se propagan de dos formas:

1. El RNA viral se retrotranscribe a DNA, integrándose en el DNA genómico del hospedador. El nuevo RNA viral transcrito a partir de ese DNA sirve como mRNA y se encapsida en nuevas partículas virales.

2. Puede que el DNA integrado no necesite ser inmediatamente transcrito, sino que puede replicarse como parte del DNA celular y propagarse a más células donde en algún momento puede ser activado y transcrito.

Los retrovirus generalmente se encuentran en la forma integrada. Su secuencia tiene dos marcos de lectura. El situado en 5' (TYA) codifica una proteína Gag, precursora de la proteína mayoritaria de la cápsida del retrovirus, y el situado en 3' (TYB) codifica la Pol, una proteína con dominios proteasa, integrasa, transcriptasa reversa y RNAsa $\mathrm{H}$.

No se han encontrado cepas de S. cerevisiae en la naturaleza sin retrotransposones Ty. 


\section{LOS NARNAVIRUS 20S RNA Y 23S RNA}

\subsection{ANTECEDENTES HISTÓRICOS}

20S RNA se describió por primera vez en 1971 por Kadowaki y Halvorson como una molécula de RNA monocatenario cuya síntesis aumentaba en las condiciones de estrés que inducen la esporulación en S. cerevisiae. Por su migración en geles de acrilamida y en gradientes de sacarosa, se estableció que debía de tener un coeficiente de sedimentación de 20S (Kadowaki y Halvorson, 1971a; Kadowaki y Halvorson, 1971b). Posteriormente, se demostró que el aumento del número de moléculas no estaba relacionado con esporulación, ya que 20S RNA también se inducía en células haploides (Garvik y Haber, 1978). En 1984, Wesolowski y Wickner describieron dos moléculas de dsRNA presentes en el citoplasma de algunas cepas de $S$. cerevisiae, W y T. Estas nuevas moléculas no guardaban relación con otros dsRNAs presentes en la levadura (L-A, L-BC) y no estaban encapsidados en viriones (Wesolowski y Wickner, 1984). Pero no fue hasta 1991 cuando tanto $20 \mathrm{~S}$ RNA como $\mathrm{W}$ fueron clonados y secuenciados de forma independiente por dos laboratorios (Matsumoto y Wickner, 1991; Rodríguez-Cousiño et al., 1991). Ambos resultaron ser dos formas moleculares del mismo elemento genético, un RNA lineal de 2.5 kb que codificaba una única proteína de 829 aminoácidos, una RNA polimerasa dependiente de RNA. Posteriormente se demostró también que, de forma similar a 20S RNA y W, 23S RNA y T eran también dos formas moleculares del mismo elemento (Esteban et al., 1992).

En 1995 se descubrió que 20S RNA se encuentra formando complejos ribonucleoproteicos con su polimerasa de forma similar a lo que ocurría con 23S RNA y p104 (Esteban et al., 1994; García-Cuéllar et al., 1995). La formación de estos complejos puede proteger al RNA de la degradación por nucleasas del hospedador, y a la polimerasa de las proteasas citoplásmáticas. Muchos virus con genoma ss-(+)RNA forman complejos con su polimerasa para aumentar la eficiencia de su replicación, ya que al estar juntos el RNA y la proteína, ésta no tiene que buscar su molde en un ambiente adverso como puede resultar el interior del hospedador (Blumenthal y Carmichael, 1979; Meyer et al., 1981).

En el año 2000 20S RNA aparece designado como virus junto a 23S RNA, formando parte de la familia Narnaviridae (van Regenmortel, 2000). 


\subsection{CARACTERÍSTICAS GENERALES}

A continuación se resumen las características principales de los virus 205 y 235 RNA. Todas ellas quedan recogidas en la Tabla 2.

\section{EL GENOMA}

Es una molécula de RNA monocatenaria y lineal de polaridad positiva de 2514 nts en el caso de 20S RNA y de 2891 nts en el de 23S RNA. Aunque inicialmente se propuso que $20 \mathrm{~S}$ RNA era circular (Matsumoto et al., 1990), su linealidad fue demostrada en 1992 y posteriormente confirmada en 1998(Rodríguez-Cousiño y Esteban, 1992; Rodríguez-Cousiño et al., 1998).

La secuencia del RNA es rica en $\mathrm{G}+\mathrm{C}$ (casi un $60 \%$ ), al contrario que su hospedador, cuya secuencia es rica en $A+U$.

Características de los extremos (Fig. 2):

a) Extremo 5': Las cinco primeras bases son GGGGC..., complementarias al extremo 3'. Todavía queda por determinar si tienen o no estructuras cap, aunque todos los datos de los que disponemos apoyan la ausencia de grupos cap.

b) Extremo 3': Las cinco últimas bases son GCCCC, con la posibilidad de una adenina añadida post-transcripcionalmente, que aparece en alrededor de un $30 \%$ de las moléculas. Aunque es un RNA mensajero (mRNA) carece de cola de poli(A). La predicción de la estructura secundaria del extremo mediante el programa MFOLD y nuestros datos experimentales, indican que el extremo $3^{\prime}$ de ambos virus se pliega en una estructura en forma de horquilla similar a la que presentan ciertos colifagos, como Q $\beta$ o SP (RodríguezCousiño et al., 1998; Mathews et al., 1999; Zuker, 2003).

El genoma viral codifica solamente una proteína, p91 (20S RNA) y p104 (23S RNA), que son sus RNA polimerasas correspondientes. Su secuencia codificante ocupa prácticamente la totalidad del genoma (Fig. 3). Las regiones sin traducir del genoma, UTR (Unstranslated Regions), son extremadamente cortas: 12 y 6 nucleótidos en $5^{\prime}$ y 12 y 59 nt en el extremo 3' de 20 S RNA y 235 RNA (Rodríguez-Cousiño et al., 1991; Esteban et al., 1992; RodríguezCousiño et al., 1998). 


\section{S RNA 23S RNA}

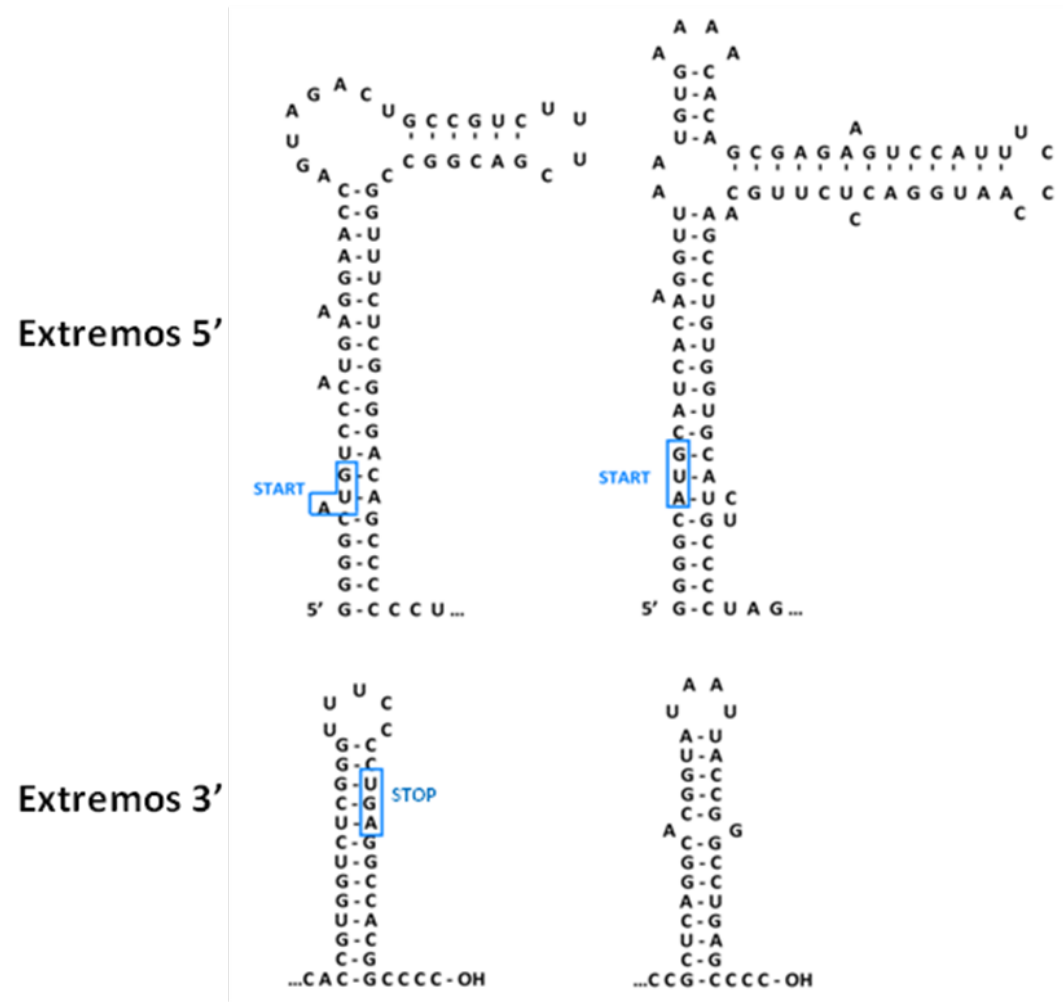

Figura 2. Estructuras secundarias de los extremos 5' y 3' de 20S RNA y 23S RNA. Están señalados los lugares de inicio de la traducción de las polimerasas respectivas p91 y p104 (START), así como el final (STOP).

\section{LA POLIMERASA}

Las polimerasas tienen 91 y 104 kDa, por lo que se denominan p91 la de 20S RNA y p104 la de 23 S RNA.

Se ha comprobado que p91 no sufre procesamiento proteolítico post-traduccional (GarcíaCuéllar et al., 1995), y posiblemente este tampoco ocurre en p104.

- En ambas proteínas existen regiones consenso conservadas en las RdRp de virus con genomas RNA monocatenario de polaridad positiva o de virus con genomas de RNA bicatenarios (Kamer y Argos, 1984; Argos, 1988; Poch et al., 1989) (Fig. 3).

Pese a que 205 y 23 S RNA no presentan homología a nivel nucleotídico, con la excepción de una secuencia de 17 nts que es idéntica en ambos, las proteínas codificadas en estas moléculas tienen un elevado grado de conservación que va más allá de las regiones 
consenso de las polimerasas, lo que sugiere un origen evolutivo común. Así, además del intervalo de 150 aminoácidos que incluye los motivos característicos de las RdRp, indicados como A, B, C y D en la figura 3, existen otras secuencias en las que más de una $50 \%$ de los aminoácidos son idénticos en ambas proteínas. Estas regiones se indican en la misma figura como 1, 2 y 3 y no ha sido encontrados en otras RNA polimerasas (Esteban et al., 1993).

20S RNA y 235 RNA se unen a sus respectivas RdRp para formar complejos ribonucleoproteicos específicos (Esteban et al., 1994; García-Cuéllar et al., 1995).

Ambos virus se localizan en el citoplasma de su hospedador, a diferencica de los mitovirus, que lo hacen en las mitocondrias (Solórzano et al., 2000).

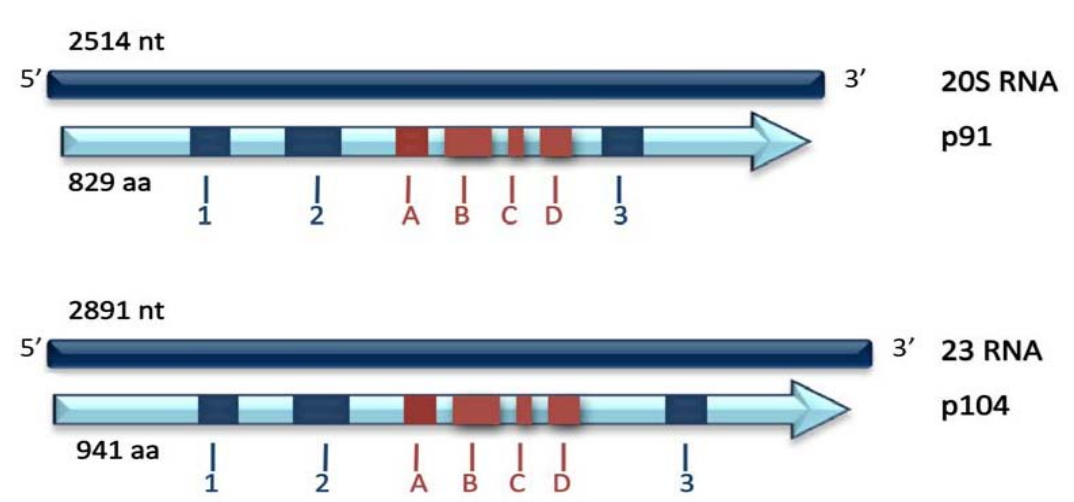

Figura 3. Esquema de la organización genómica de los virus 20S RNA y 235 RNA. La línea superior corresponde al genoma viral y la flecha a la polimerasa codificada en él. Las regiones marcadas como A, B, C y D son dominios altamente conservados entre las RdRp virales, mientras que las zonas 1, 2 y 3 son regiones muy conservadas entre las polimerasas de ambos virus.

TABLA 2. Características principales de los narnavirus 20S RNA y 235 RNA

\begin{tabular}{l|c|c}
\hline Características & 20S RNA & 23S RNA \\
\hline Tamaño del genoma & $2514 \mathrm{nt}$ & $2891 \mathrm{nt}$ \\
dsRNA asociado & $\mathrm{W}$ & $\mathrm{T}$ \\
$\mathbf{5}$ ' UTR & $12 \mathrm{nt}$ & $6 \mathrm{nt}$ \\
3' UTR & $12 \mathrm{nt}$ & $59 \mathrm{nt}$ \\
Proteína codificada & p91 & p104 \\
Abundancia & $\begin{array}{l}90 \% \text { cepas laboratorio } \\
\text { 20\% cepas industriales } \\
\text { (Esteban y Rodríguez- } \\
\text { Cousiño, 2008) }\end{array}$ & $\begin{array}{l}\text { Sólo algunas cepas de } \\
\text { laboratorio y un 2\% } \\
\text { de cepas industriales. }\end{array}$ \\
\hline
\end{tabular}




\section{LOS COMPLEJOS RIBONUCLEOPROTEICOS COMO UNIDAD VIRAL}

Tal y como se comentó en el apartado 1.2.2, tanto 20S RNA como 23S RNA se encuentran formando complejos ribonucleoproteicos en la célula. Esta es la forma en la que el virus se encuentra en el citoplasma de su hospedador. Se considera "unidad viral" al complejo formado entre el genoma viral y su RNA polimerasa.

La formación de los complejos polimerasa/RNA de estos virus se comprobó en los años 1994 y 1995 mediante experimentos de cosedimentación e inmunoprecipitación (Esteban et al., 1994; García-Cuéllar et al., 1995).

\section{a) Cosedimentación}

Cuando lisados celulares parcialmente purificados se someten a centrifugación en gradientes de sacarosa, tanto p91 como p104 sedimentan en las mismas fracciones en las que lo hacen sus respectivos RNAs. Esta sedimentación depende de la presencia del genoma viral, ya que un tratamiento previo con RNAsas modifica la movilidad de las proteínas hacia fracciones más ligeras del gradiente, lo que sugiere una asociación entre el RNA y la polimerasa.

\section{b) Coinmunoprecipitación}

La interacción específica entre los genomas de $20 S$ y 235 RNA con sus respectivas polimerasas fue confirmada inmunoprecipitando 20S RNA, pero no 23S RNA con anticuerpos antip91, y de manera similar, anticuerpos anti-p104 inmunoprecipitan 23S RNA pero no 20 S RNA.

\subsection{CARACTERÍSTICAS Y TIPOS DE COMPLEJOS VIRALES}

\section{LOCALIZACIÓN Y ESTEQUIOMETRÍA}

Los complejos se encuentran distribuidos en el citoplasma de S. cerevisiae sin asociarse a orgánulos del hospedador. Durante el crecimiento logarítmico de S. cerevisiae, debido a que hay un menor número de moléculas de 20 S RNA, se observa que p91 tiende a formar agregados, lo que en inmunofluorescencia se ve como focos. Sin embargo, en condiciones de estrés nutricional (ausencia de nitrógeno en el medio) el número de moléculas de 20S RNA puede aumentar hasta 10.000 veces, lo que hace que p91 se asocie con este RNA formando complejos estables. En este caso p91 aparece distribuido de forma difusa en el citoplasma del hospedador. Esta interpretación está apoyada por el hecho de que polimerasas expresadas a partir de un vector de expresión forman agregados incluso 
en células durante estrés nutricional, si no existe RNA viral para formar los complejos (Fig. 4) (Solórzano et al., 2000).

La estequiometría del RNA y la proteína en los complejos es de 1:1 (una molécula de RNA y una molécula de proteína). La polimerasa se estabiliza uniéndose al RNA (y viceversa). Además, se ha comprobado que casi todo el RNA viral se encuentra formando complejos. Esta asociación ayuda a los virus a protegerse de los mecanismos de degradación del RNA del hospedador, clave en la supervivencia viral (Solórzano et al., 2000).

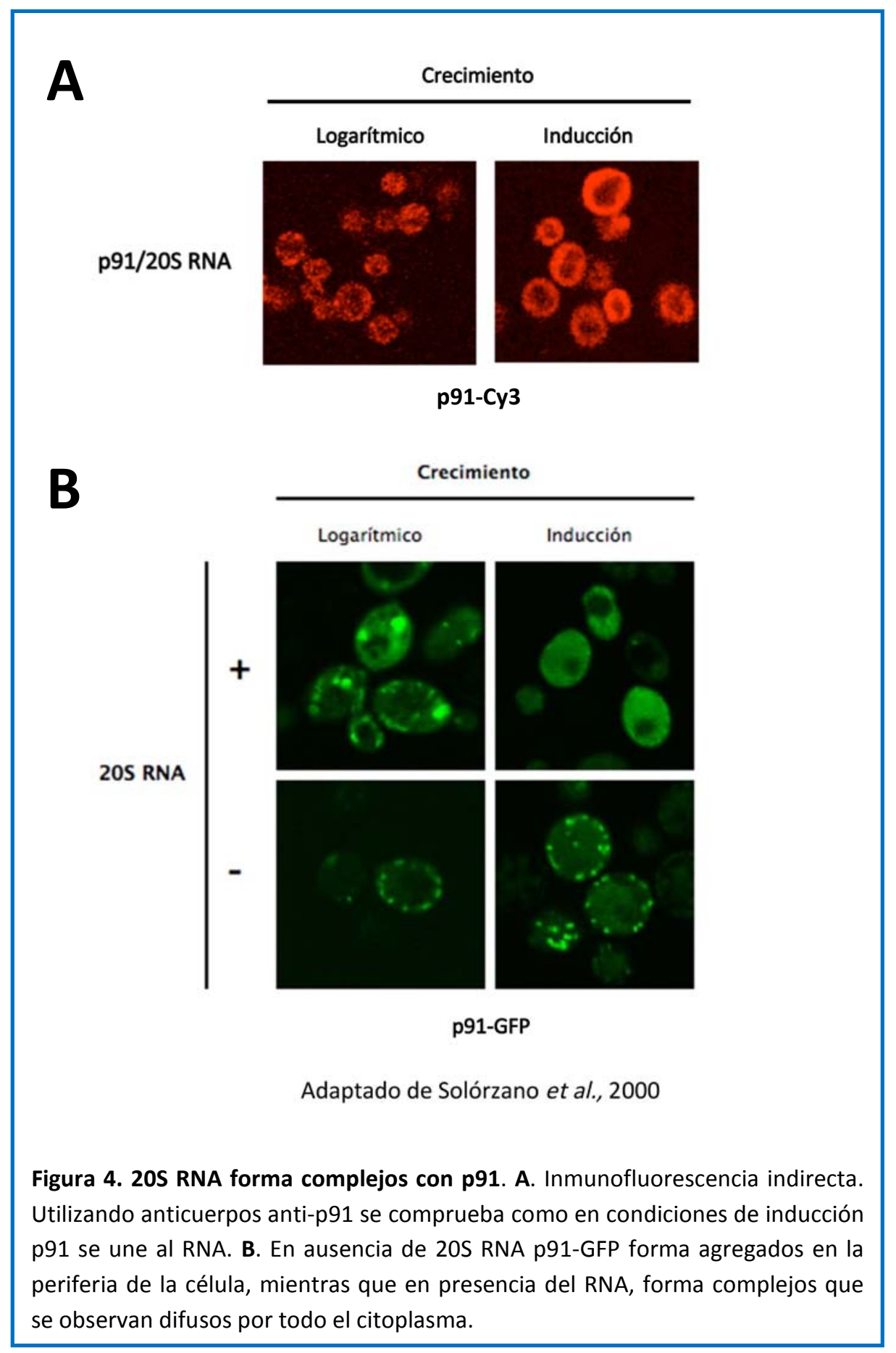




\section{TIPOS DE COMPLEJOS}

Destacar por último, que en $S$. cerevisiae podemos encontrar dos tipos de complejos dependiendo del estado metabólico del virus: complejos activos (o en replicación) y complejos en reposo. Los primeros se replican activamente, y de ellos se hablará en el apartado 4.1, mientras que los complejos en reposo se pueden considerar como formas de resistencia del virus, ya que se acumulan en la célula en condiciones de estrés, especialmente en ausencia de nitrógeno.

\section{REPLICACIÓN DE 20S RNA}

Los virus RNA, según la polaridad de su genoma, pueden dividirse en tres grupos, lo que indicará su estrategia de replicación (White, 1994).

- Virus con genoma RNA monocatenario de polaridad (+). El genoma de estos virus tiene, además, capacidad de mensajero.

- Virus con genoma RNA monocatenario de polaridad (-). El RNA genómico tiene que replicarse para dar lugar a un RNA complementario, que es el que tiene capacidad codificante.

\section{- $\quad$ Virus con genoma RNA bicatenario.}

En cualquiera de los tres casos, se requieren RdRp para su replicación. Estas polimerasas son específicas y necesitan estar codificadas en el genoma del virus en su totalidad o al menos, alguna de las subunidades necesarias para esta actividad enzimática. A continuación se resumen los principales modelos de replicación del primer y tercer grupo, los más relacionados con el virus objeto de nuestro estudio.

\subsection{REPLICACIÓN EN VIRUS CON GENOMA RNA MONOCATENARIO DE POLARIDAD (+)}

El genoma de estos virus tiene polaridad de mensajeros, de tal modo que dentro de la célula hospedadora son traducidos directamente para dar lugar a la RdRp y otras proteínas. La polimerasa sintetizará el RNA, utilizando el RNA genómico como molde, lo que dará lugar a las cadenas (-). Éstas son empleadas como molde para dar lugar de nuevo a las formas genómicas (+). 
Uno de los primeros ciclos de virus de este tipo en ser estudiado fue el del bacteriófago $Q \beta$, que podría estar relacionado con $20 S$ y 23 S RNA, ya que son bastante parecidos a nivel estructural (tienen los extremos 3' muy parecidos, (Fujimura y Esteban, 2004a)) y sus RdRp mantienen cierto grado de conservación (Fig. 1).

\subsubsection{REPLICACIÓN DE LOS VIRUS 20S Y 23S RNA}

Los virus $20 S$ y $23 S$ RNA tienen que replicarse en las células durante el crecimiento de $S$. cerevisiae y transmitirse equitativamente a los descendientes mitóticos o meióticos. Gracias a un sistema de replicación in vitro puesto a punto en nuestro laboratorio se han obtenido datos que indican que el modelo de replicación de estos virus es el siguiente:

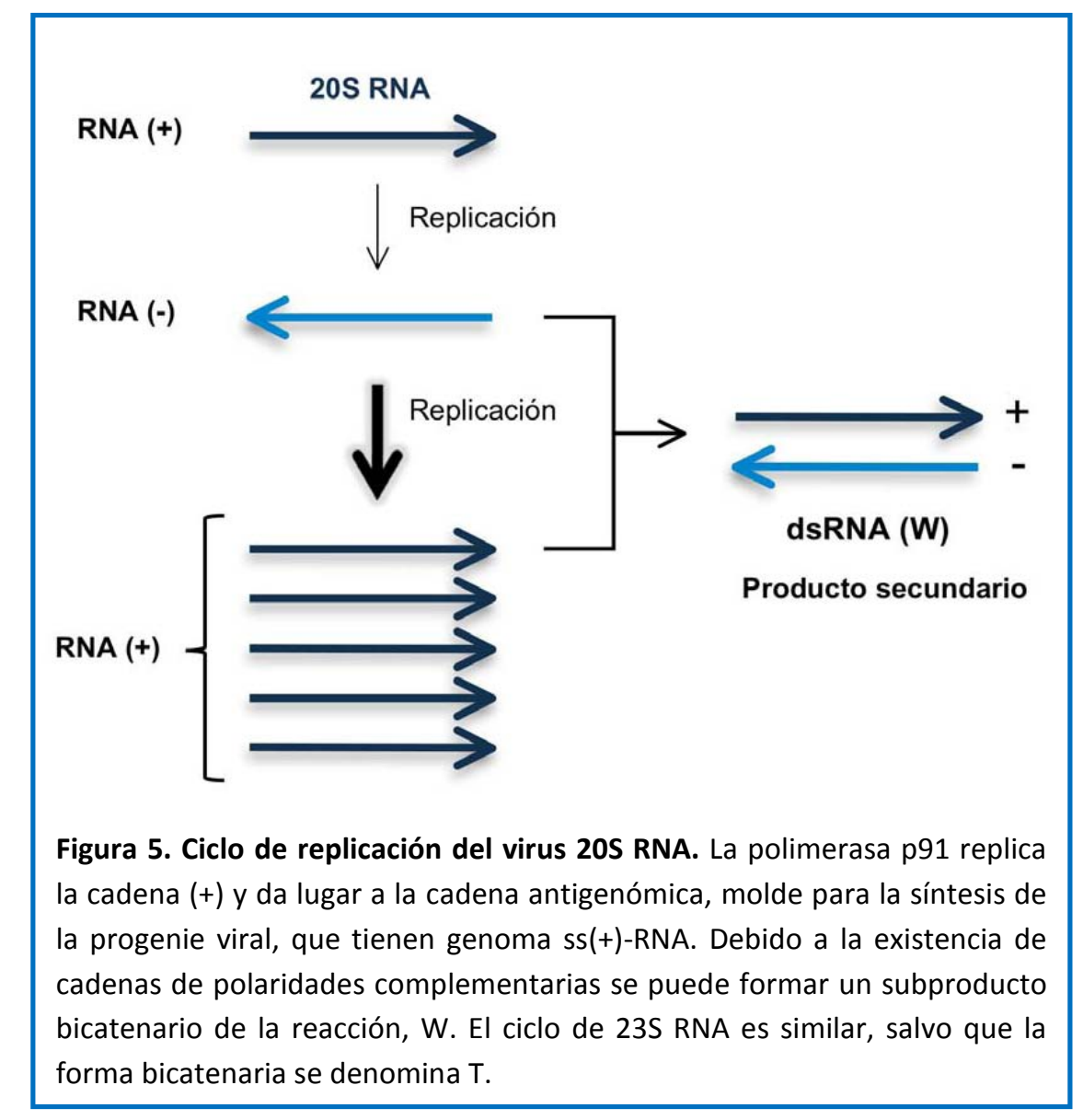

Las cadenas (+) sirven como molde para la síntesis de cadenas (-) y éstas, a su vez, serán replicadas para dar lugar a nuevas cadenas (+). Esta segunda reacción se ve favorecida, ya que en la célula se acumulan principalmente cadenas (+), dando lugar a una replicación asimétrica. Durante este proceso, se forman complejos ribonucleoproteicos no sólo con la cadena (+) del virus, sino también con la cadena (-). Las formas bicatenarias W y T se originan como un subproducto de la replicación, debido al anillamiento de cierto número de moléculas de ambas polaridades (Fujimura 
et al., 2005). Ciertas condiciones favorecen la aparición de estas moléculas, por ejemplo, el crecimiento de las células a alta temperatura $\left(37^{\circ} \mathrm{C}\right)$ o la extracción con fenol durante la preparación de los RNAs. Como ya se ha comentado, la secuencia de los extremos 5' y $3^{\prime}$ de 205 y $23 S$ RNA son complementarias, lo que indica que la maquinaria de replicación requiere la misma secuencia en el extremo 3' para iniciar la síntesis de las cadenas de polaridad positiva y negativa.

\subsection{REPLICACIÓN DE VIRUS CON GENOMA RNA BICATENARIO}

Los virus con este tipo de genoma están enmarcados en diferentes familias en función de su morfología, organización y contenido en RNA. Además, es un grupo ampliamente distribuido en la naturaleza, aunque todos ellos presentan un patrón de replicación similar. Este proceso tiene lugar en el citoplasma de las células hospedadoras dentro de la cápsida (Levy, 1994).

El ciclo consiste en la transcripción del RNA genómico en un ss-(+)RNA en el interior de la cápsida. Este RNA transcrito tiene dos funciones una vez que sale de la partícula viral: por una parte, sirve como mRNA y por otra, vuelve a encapsidarse y sirve de molde para sintetizar la cadena complementaria. En todos los casos, la RdRp tiene una doble función como replicasa y transcriptasa.

A continuación voy a describir brevemente el ciclo replicativo del virus L-A, presente en S. cerevisiae, y que ha sido ampliamente estudiado.

\subsubsection{REPLICACIÓN DEL VIRUS L-A DE S. cerevisiae}

El ciclo de replicación del virus L-A de S. cerevisiae se conoce en detalle. Este virus está encapsidado en una cápsida icosaédrica de 120 unidades de una proteína de $76 \mathrm{kDa}$. El ciclo de replicación de este virus se propuso a partir de los resultados obtenidos con partículas víricas purificadas. Se considera que hay tres etapas esenciales (Fig. 6).

1. Transcripción: la actividad transcriptasa es la actividad enzimática que sintetiza moléculas de RNA monocatenario con polaridad de mensajero a partir de un RNA bicatenario como molde. Estas moléculas salen el exterior de la partícula y dado que pueden traducirse actuarán como mRNAs para dar lugar a las dos proteínas codificadas por ellos: la proteína mayoritaria de la cápsida Gag y una proteína de fusión Gag-Pol con un dominio idéntico al de la proteína de la cápsida y otro en el que se encuentran secuencias consenso de RNA polimerasas virales dependientes de RNA. Durante esta etapa, el RNA viral se encuentra vulnerable en el citoplasma de S. cerevisiae, no encapsidado, susceptible de ser atacado por alguna exonucleasa del hospedador. 
2. Encapsidación: las cadenas (+), además de ser traducidas, se encapsidan para dar lugar a partículas con la misma composición proteica que las partículas originales, pero con una molécula de ssRNA en su interior.

3. Replicación: utilizando como molde la cadena $(+)$, se sintetizan en las partículas la cadena complementaria para dar lugar a la molécula dsRNA original. (Fujimura et al., 1986; Fujimura y Wickner, 1987).

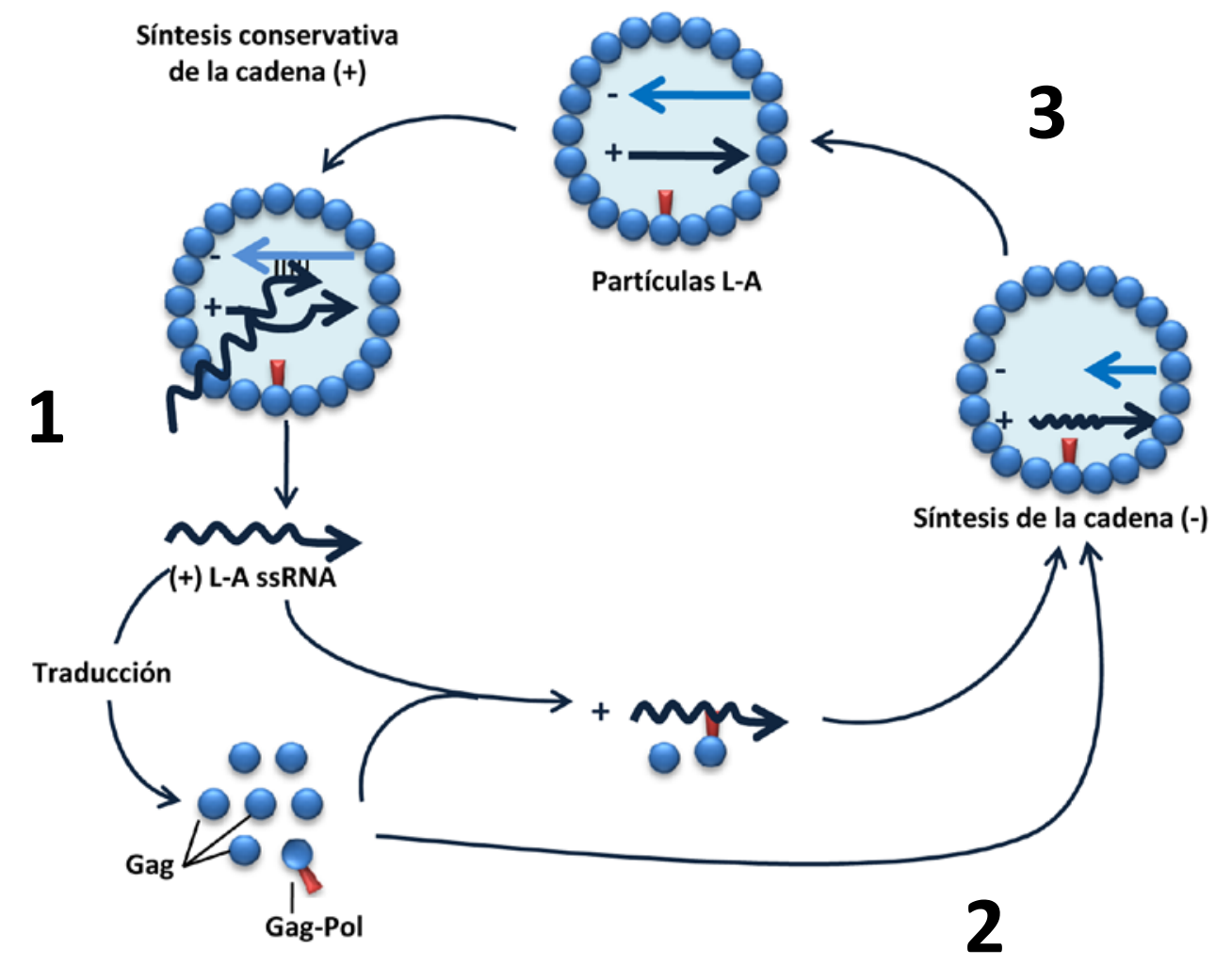

Proteínas de la cápsida

Figura 6. Ciclo de vida del virus L-A de S. cerevisiae. El ciclo consta tres etapas en las que el genoma viral se replica, se traduce para dar lugar a las proteínas de la cápsida (Gag) y a la polimerasa (Gag-Pol) y se encapsida en viriones. 


\section{ESTUDIOS DE GENÉTICA REVERSA EN NARNAVIRUS}

En el año 2003 se consiguió generar in vivo el virus 23S RNA a partir de un vector de expresión de levaduras (Esteban y Fujimura, 2003). Con este nuevo sistema, se puede hacer genética reversa y conocer en detalle las señales necesarias para su replicación y la formación de los complejos virales.

\subsection{GENERACIÓN DE 23S RNA A PARTIR DE UN VECTOR DE EXPRESIÓN}

Se clonó el cDNA de 23S RNA en el plásmido pl2 bajo el promotor constitutivo PGK1 (del gen que codifica la Fosfoglicerato quinasa 1) (Wickner et al., 1991). En el extremo 3' del cDNA se fusionaron $82 \mathrm{nt}$ de la cadena antigenómica de la ribozima del virus delta de la hepatitis (HDV) (Perrotta y Been, 1990; Perrotta y Been, 1991). La ribozima tiene señales de autoprocesamiento, de tal manera que los transcritos generados a partir del vector se cortarán justo por delante de su secuencia, generando un extremo 3' idéntico al del virus 23S RNA (Fig. 7). Cuando se puso a punto este sistema, en el laboratorio no se tenía ninguna cepa que no tuviera 20S RNA, causa por la que el virus elegido fue 23S RNA.

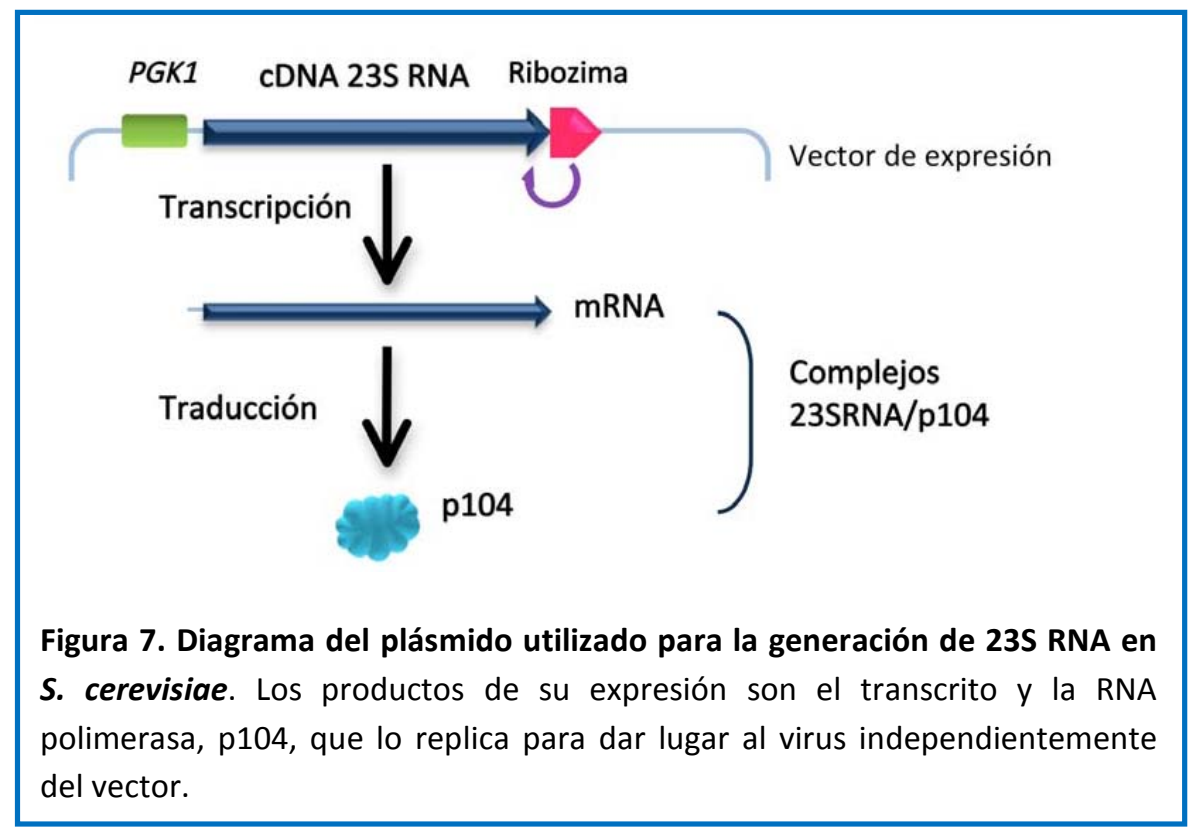

El plásmido se introdujo en una cepa de $S$. cerevisiae que carecía del virus, y el RNA de los transformantes se extrajo y analizó mediante Northern Blot (apartado 3.9 de Materiales y Métodos) hibridándolo con sondas específicas de las cadenas de polaridad positiva y negativa de 23S RNA. Se comprobó que ambas sondas detectaban una molécula a la altura de 23S RNA. El hecho de detectar 
las cadenas de polaridad (-) del virus indica que éste se ha generado a partir del plásmido pero es independiente de él, ya que la síntesis de la cadena (-) es un proceso que ocurre durante la replicación viral. La autonomía del virus generado se confirmó eliminando el plásmido de las células previamente transformadas y comprobando que el virus se mantenía en la célula durante al menos cien generaciones. El virus generado puede inducirse en ausencia de nitrógeno en el medio y el RNA viral puede observarse directamente en geles de agarosa teñidos con bromuro de etidio (Fig. 8). La relación entre las cadenas de polaridades $(+)$ y $(-)$ es la misma que en el virus endógeno, indicando que el virus generado in vivo es, a todos los efectos, idéntico al virus endógeno de $S$. cerevisiae.

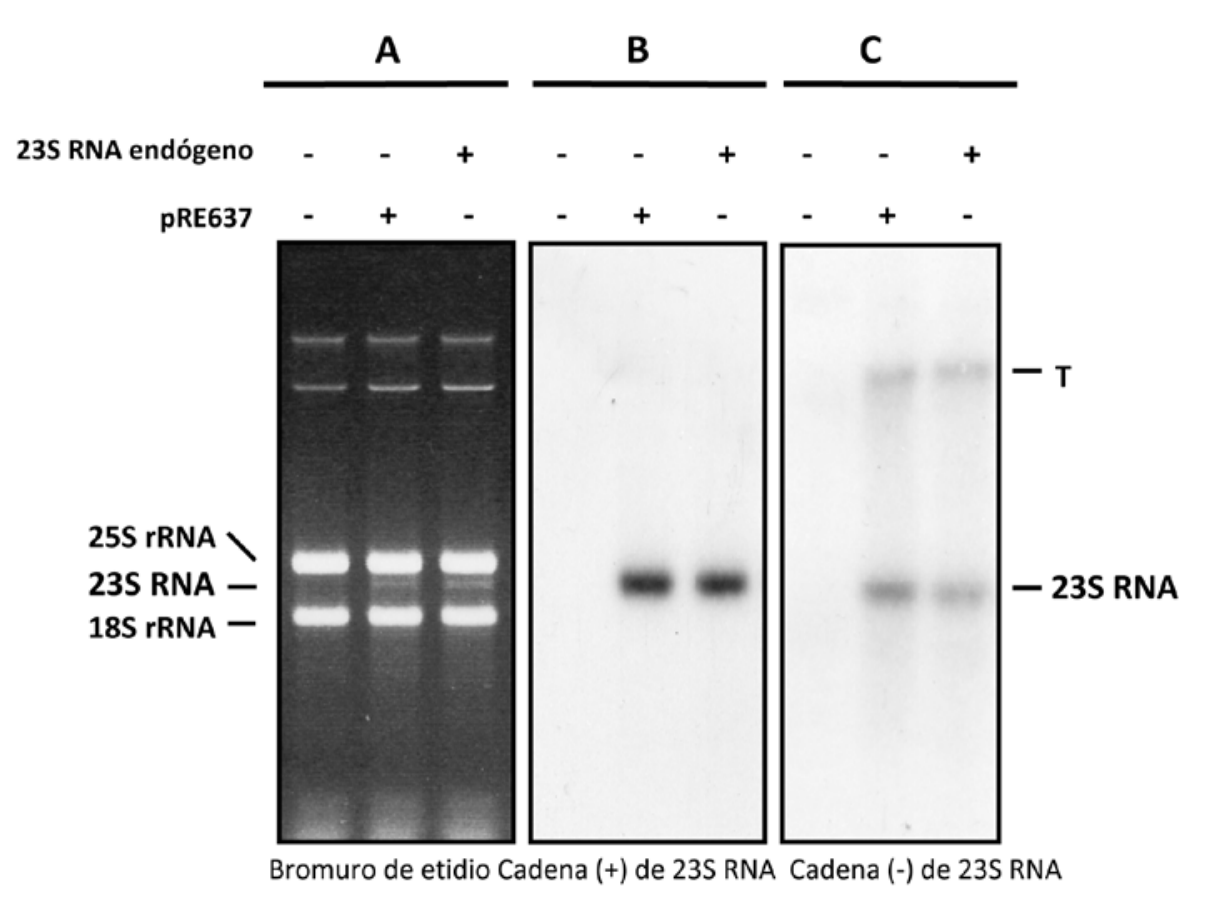

Figura 8. Generación de 235 RNA en S. cerevisiae. A. La cepa 2928-4 (que carece del virus) se transforma con el plásmido de expresión y después de extraer el RNA de las células se observa el genoma viral en un gel teñido con bromuro de etidio. B. y C. Las cadenas (+) y (-) del RNA viral se detectan mediante Northern Blot. La cantidad de virus generado es similar al de la cepa con el virus endógeno (2928-5).

Esta estrategia permite estudiar, a nivel nucleotídico, las bases importantes en replicación y formación de los complejos ribonucleoproteicos entre el genoma viral y su polimerasa, ya que se puede modificar la secuencia del genoma viral en el plásmido de expresión (in vitro) y posteriormente comprobar si los cambios introducidos afectan a la generación de 23S RNA (in vivo). Además, también se puede modificar la secuencia de la polimerasa, y encontrar los aminoácidos significativos para su correcta actividad. 


\subsection{RESUMEN DE LOS RESULTADOS SOBRE LA REPLICACIÓN DE 23S RNA}

Gracias a este sistema sabemos que 235 RNA tiene en su extremo $3^{\prime}$ dos señales en cis (presentes en su propia secuencia), necesarias para la replicación y formación de los complejos p104/23S RNA (Fujimura y Esteban, 2004; Fujimura y Esteban, 2004a). Modificando el cDNA viral en los cuatro últimos nucleótidos de la secuencia, se comprobó que la tercera y cuarta citosina (comenzando desde el extremo $3^{\prime}$ ) son esenciales para la formación de complejos y replicación del virus, ya que el cambio o eliminación de estos nucleótidos impiden que se genere 23S RNA. Además, el extremo $3^{\prime}$ del genoma viral tiene una estructura secundaria en forma de horquilla (Fig. 9), con dos purinas desapareadas en la zona central del brazo. Modificando la secuencia de la estructura se detectó que para la generación, formación de los complejos ribonucleoproteicos y replicación del virus, es imprescindible la presencia de dos purinas (cualesquiera) desapareadas en la zona central de dicha estructura. De los estudios realizados con este virus se pone de manifiesto la importancia del extremo 3', tanto a nivel de su secuencia primaria (las cuatro últimas citosinas) como de su estructura secundaria.

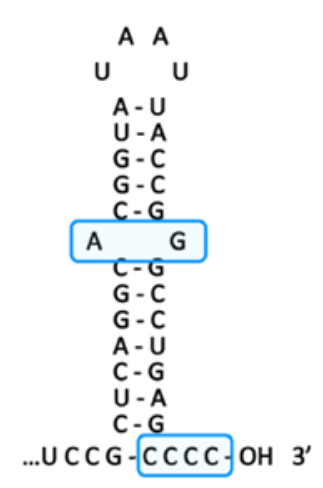

Figura 9. Estructura secundaria presente en el extremo 3' de la cadena (+) de 235 RNA. En azul están marcadas las señales en cis necesarias para la replicación y formación de complejos con $\mathrm{p} 104$. 


\section{SISTEMAS DE DEGRADACIÓN DE mRNAs EN EL CITOPLASMA DE S. cerevisiae}

En S. cerevisiae existen varios sistemas para regular la cantidad (y calidad) de los RNAs celulares. Ya que el genoma de 20S RNA se comporta como un mRNA que utiliza para traducirse la maquinaria del hospedador, es posible que su estabilidad pueda estar afectada por alguno de estos procesos. Los principales sistemas de degradación de los mensajeros celulares son dos, el Deccaping y el exosoma.

\subsection{DECAPPING DEPENDIENTE DE DESADENILACIÓN}

Este proceso consta de tres etapas, como se muestra en la Fig. 10:

a) Desadenilación: acortamiento de la cola de poli(A) en el extremo 3' hasta aproximadamente 12 residuos. Se lleva a cabo por el complejo Ccr4p/Caf1p y las proteínas Not1p - 5p (Tucker et al., 2002).

b) Decapping: Eliminación del grupo cap del extremo 5' del mRNA. La enzima principal encargada del proceso en levaduras es Dcp2p (responsable de la actividad hidrolasa), que produce transcritos con un extremo 5' monofosfato, susceptibles de ser degradados por una exonucleasa $5^{\prime} \rightarrow 3^{\prime}$. La enzima está regulada por Dcp1p y Dhh1p (Dunckley et al., 2001; Tucker et al., 2002). En este proceso participan además el complejo Lsm1-7p, que facilitan la unión de la maquinaria de decapping al mRNA y la degradación del mensajero (He y Parker, 2000; Tharun et al., 2000).

c) Degradación: Las moléculas sin poli(A) ni cap, son degradadas por la enzima Xrn1p/Ski1p. Esta proteína es la exonucleasa $5^{\prime} \rightarrow 3^{\prime}$ citoplasmática principal en eucariotas. Su deleción acumula mRNAs sin cap ni poli(A) (Hsu y Stevens, 1993; Johnson y Kolodner, 1995). La enzima se detiene ante fuertes estructuras secundarias y colas de poli(G). (Stevens, 2001; Tucker et al., 2002). La degradación de estos RNAs ocurre en los P-bodies (Processing bodies), focos discretos en el citoplasma de S. cerevisiae y al igual que el deccaping, está facilitado por el complejo Lsm1-7p (Bouveret et al., 2000; Long y McNally, 2003; Sheth y Parker, 2003). 
Ya que 20S RNA carece de poli(A), y muy probablemente de cap, el genoma del virus puede ser un buen candidato para degradarse mediante la acción de la exonucleasa Xrn1p/Ski1p, cuyas características principales se resumen en el apartado 6.3.

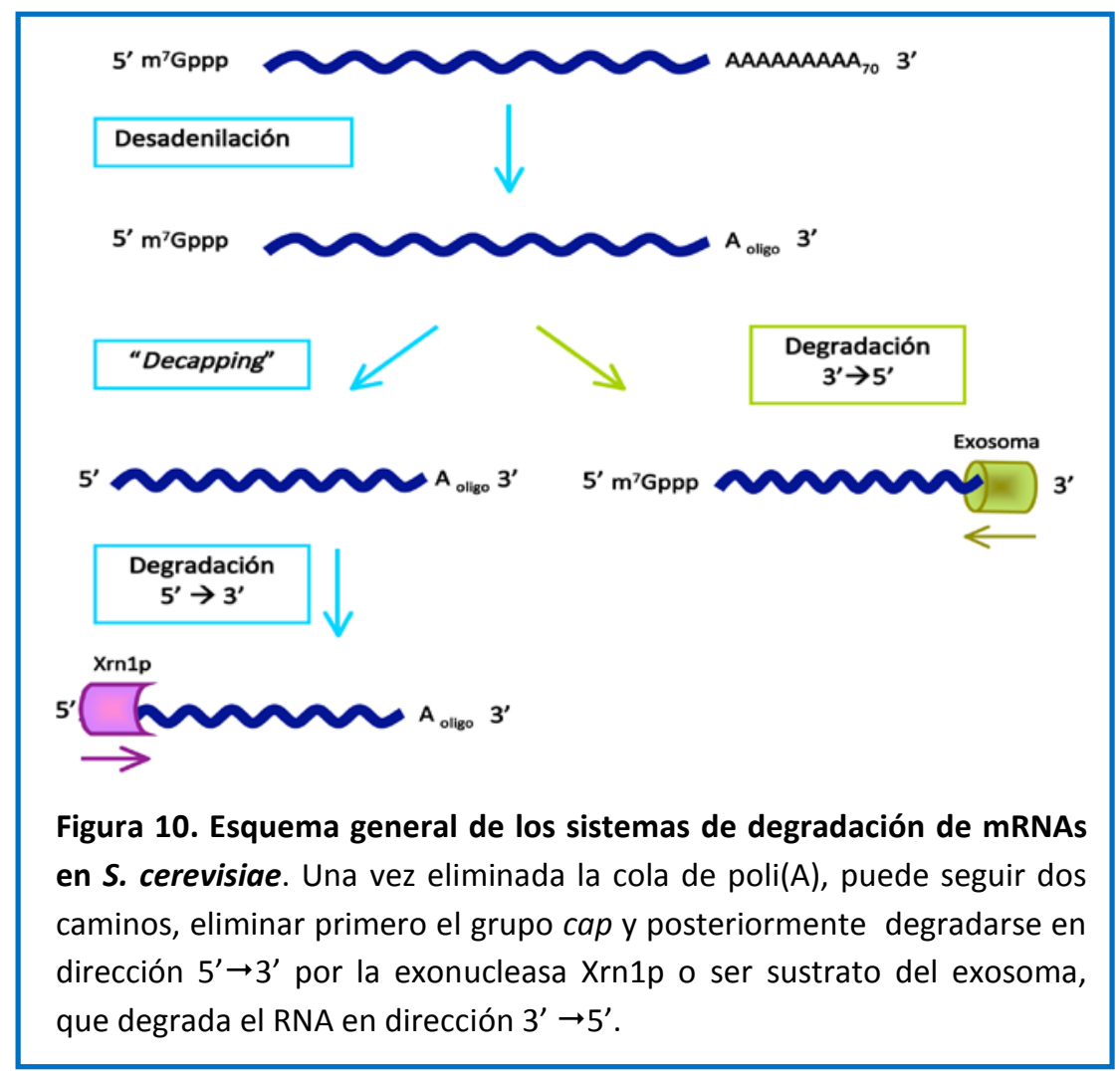

\subsection{EXOSOMA}

El exosoma es un complejo multiproteico altamente conservado en eucariotas encargado de la degradación de los mRNAs en sentido $3^{\prime} \rightarrow 5^{\prime}$. En S. cerevisiae se describió por primera vez en 1997 como un sistema que además de degradar mRNAs (Mitchell et al., 1997). Algunas de las proteínas que lo forman y regulan ejercen un efecto antiviral sobre virus dsRNA. (Widner y Wickner, 1993). Tiene un papel crucial en el metabolismo del RNA, incluyendo la degradación y maduración del RNA ribosomal y calidad del RNA y recambio (turnover) de los mensajeros (Houseley et al., 2006). Se encuentra tanto en el núcleo como en el citoplasma de la célula. Consiste en un complejo formado por diez subunidades, de las cuales nueve constituyen un núcleo en forma de anillo compuesto por tres heterodímeros de seis proteínas diferentes, Rrp41p-Rrp45p, Rrp46p-Rrp43p y Mtr3-Rrp42p (Lehner y Sanderson, 2004; Hernandez et al., 2006; Liu et al., 2006). Sin embargo, para su ensamblaje, el anillo requiere tres proteínas adicionales, Rrp4p, Csl4p (Ski4p) y Rrp40, que contienen dominios de unión a RNA y podrían ser las encargadas de de unir los sustratos del exosoma 
(Schaeffer et al., 2009). Su estructura actúa como una plataforma de reconocimiento del RNA y el ensamblaje de los diferentes activadores que participan en el proceso. Además, existe una subunidad esencial más, Rrp44p (conocida también como Dis3p), responsable de la actividad $3^{\prime} \rightarrow 5^{\prime}$ exonucleasa (Dziembowski et al., 2007). El esquema del exosoma se representa en la figura 11.

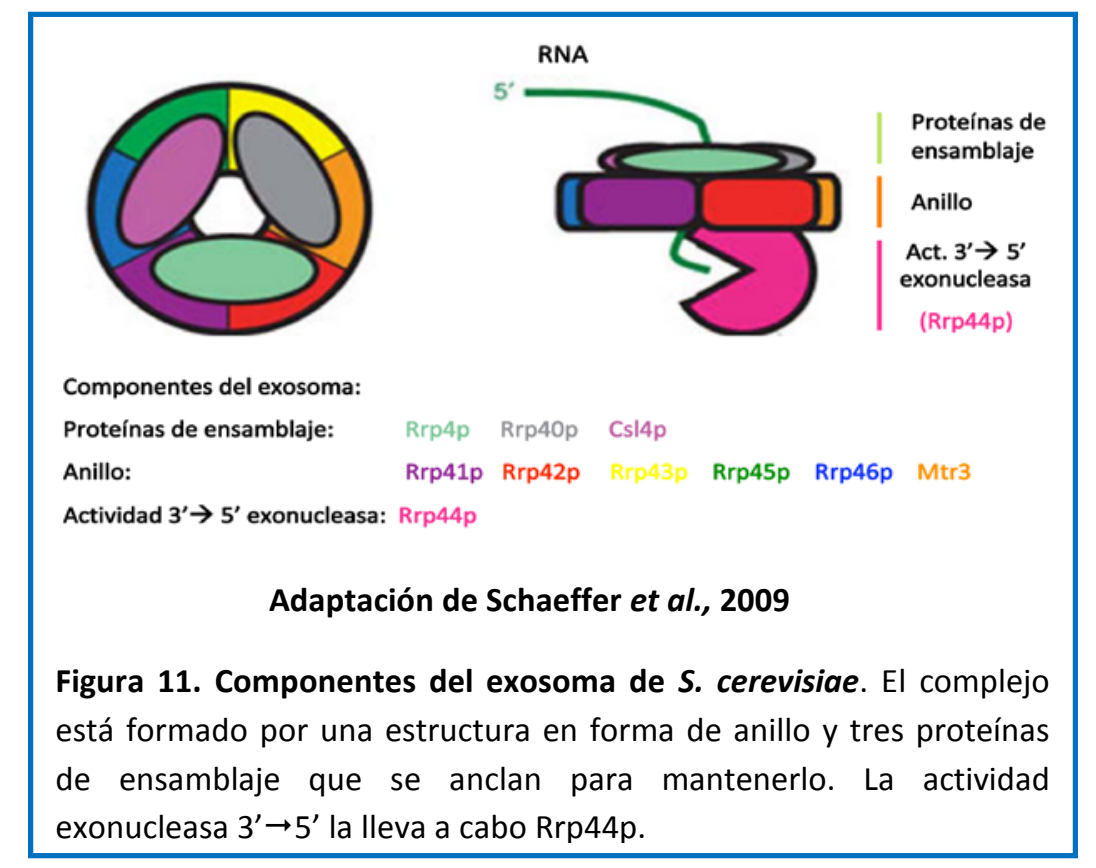

\subsection{LOS GENES SKI}

En 1978 se describió que mutaciones en ciertos genes, producían fenotipo superkiller en las cepas de S. cerevisiae, es decir, incrementaban la secreción de la toxina killer, y por lo tanto su fenotipo era más gresivo frente a las cepas sensibles. A estos genes se los denominó SKI (Superkiller) (Toh et al., 1978). Posteriormente se comprobó, que el número de copias de los virus killer (L-A), y del virus L-BC aumentaba en estos mutantes, indicando el efecto antiviral de esas mutaciones (Toh y Wickner, 1980; Widner y Wickner, 1993). Se ha comprobado que el motivo del efecto antiviral de las mutaciones en los genes $S K I$ no depende de los virus ni del sistema killer, sino en que estos genes están involucrados en la degradación de los mensajeros del hospedador, por lo que un fallo en este sistema, induce la acumulación de RNAs en el citoplasma de S. cerevisiae (Johnson y Kolodner, 1995).

Los genes SKI se resumen en la tabla 3. Además, dedicaré unas líneas a comentar alguna de las características más importantes de los genes XRN1/SKI1 y $S K I 2$, importantes en este trabajo. 
TABLA 3. Genes SKI de S. cerevisiae

\begin{tabular}{|c|c|c|}
\hline Gen & Función & Referencias \\
\hline SKI1 (XRN1) & $\begin{array}{l}\text { Exonucleasa } 5^{\prime} \rightarrow 3^{\prime} \text { implicada en multitud de } \\
\text { procesos biológicos. }\end{array}$ & $\begin{array}{l}\text { (Johnson y Kolodner, 1995) } \\
\text { (Stevens, 2001) }\end{array}$ \\
\hline$S K I 2$ & $\begin{array}{l}\text { Helicasa de RNA implicada en la degradación de } \\
\text { mRNA } 3^{\prime} \rightarrow 5^{\prime} \text {. Forma parte del complejo SKI con } \\
\text { Ski3p y Ski8. }\end{array}$ & $\begin{array}{l}\text { (Anderson y Parker, 1998) } \\
\text { (Brown et al., 2000) }\end{array}$ \\
\hline SKI3 (SKI5) & $\begin{array}{l}\text { Regula el exosoma. Forma el Complejo SKI con } \\
\text { Ski2p y Ski8py además inhibe la presecia de } \\
\text { formas no poliadeniladas. }\end{array}$ & (Brown et al., 2000) \\
\hline SKI4 (CSL4) & $\begin{array}{l}\text { Proteína de ensamblaje del núcleo del exosoma. } \\
\text { Esencial. }\end{array}$ & (van Hoof et al., 2000) \\
\hline SKI6 (RRP41) & Subunidad del anillo del exosoma. Esencial. & (Benard et al., 1998) \\
\hline SKI7 & $\begin{array}{l}\text { Proteína adaptadora entre el exosoma y el } \\
\text { complejo SKI. }\end{array}$ & $\begin{array}{l}\text { (van Hoof et al., 2000) } \\
\text { (Araki et al., 2001) } \\
\text { (Wang et al., 2005) }\end{array}$ \\
\hline SKI8 (REC103) & $\begin{array}{l}\text { Forma parte del complejo SKI con Ski2p y Ski3p. } \\
\text { Además está implicada en la rotura de doble } \\
\text { cadena durante la meiosis. }\end{array}$ & $\begin{array}{l}\text { (Gardiner et al., 1997) } \\
\text { (Brown et al., 2000) } \\
\text { (Arora et al., 2004) } \\
\text { (Brown et al., 2000) }\end{array}$ \\
\hline
\end{tabular}

\section{XRN1/SKI1}

Este gen codifica la exonucleasa $5^{\prime} \rightarrow 3^{\prime}$ citoplasmática más importante en $S$. cerevisiae, Xrn1p. Esta proteína es necesaria para funciones a distintos niveles de los procesos celulares, como la degradación de mRNA y DNA de cadena sencilla, el correcto ensamblaje del retrotransposon Ty3 (Brown et al., 2000), ensamblaje de la tubulina en microtúbulos (Interthal et al., 1995), ciclo celular (Pathak et al., 2005) o cariogamia (Kim et al., 1990) entre otros. Debido a esta multifuncionalidad, el gen ha recibido otros nombres, como DST2, RAR5, SKI1, KEM1...

La enzima tiene 1528 aminoácidos y se localiza en los $P$-bodies, o cuerpos de procesamiento del RNA, en el citoplasma (Sheth y Parker, 2003). Aunque la deleción del gen no afecta a la viabilidad celular, sí produce ciertos efectos fenotípicos, como crecimiento lento, dificultad en la separación de los cromosomas en el cuerpo polar del huso (spindle body), muerte en ausencia de nitrógeno, deficiencias en recombinación durante la meiosis, y el diploide homozigótico no puede esporular. Es sintético letal con otros genes que participan en la degradación de RNAs, como SKI2 o SKI8 (Anderson y Parker, 1998).

Esta exonucleasa tiene especial predilección por sustratos sin poliadenilar ni cap, por lo que es probable que los genomas de virus RNA de $S$. cerevisiae como 20S RNA y 23 S RNA puedan ser dianas de esta proteína (Hsu y Stevens, 1993; Johnson y Kolodner, 1995). 
El gen SKI2 codifica una helicasa de RNA de 146 kDa que utiliza la hidrólisis del ATP para producir cambios conformacionales en la estructura del RNA o en las interacciones RNA proteína (de la Cruz et al., 1999). Se encuentra formando parte de un heterotetrámero junto con una molécula de Ski3p y dos de Ski8p (Synowsky y Heck, 2008). Este complejo citoplasmático es esencial para la correcta actividad del exosoma (Anderson y Parker, 1998; Brown et al., 2000).

La deleción de este gen no produce efecto fenotípico evidente sobre su hospedador, aunque sí se observa un incremento del RNA citoplasmático que carece de grupos cap y sin poli(A) (Anderson y Parker, 1998).

Dado el efecto antiviral demostrado en el virus L-A (Widner y Wickner, 1993), y al participar en la degradación de mensajeros citoplasmáticos, el número de copias del virus 20S RNA podría estar también regulado por Ski2p. 


\section{OBJETIVOS}

$\because: \because: 8$

"Probamos a través de la lógica, pero descubrimos con la intuición" ARISTÓTELES 


\section{OBJETIVOS}

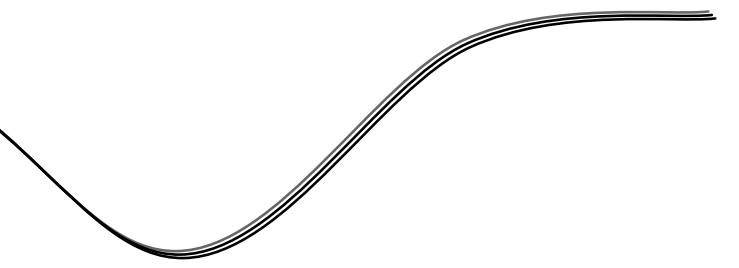

Al comienzo de este trabajo se acababa de poner a punto en el laboratorio el sistema de generación de 20S RNA a partir de la expresión de su cDNA clonado en un plásmido. Esto nos permitía realizar experimentos de genética reversa para conocer in vivo las señales en cis necesarias en su replicación. Asimismo, se podía abordar el estudio de factores del hospedador implicados en su mantenimiento.

Por consiguiente, los objetivos planteados en este trabajo son los siguientes:

1. Estudio de las señales en cis que afectan a la replicación y formación de complejos p91/20S RNA.

2. Efecto de los sistemas de degradación de mRNAs de $S$. cerevisiae en la generación y mantenimiento de 20S RNA.

3. Identificar posibles factores del hospedador formando parte de los complejos ribonucleoproteicos p91/20S RNA. 
MATERIALES Y MÉTODOS

- l

\%:

“En principio la investigación necesita más cabezas que medios" SEVERO OCHOA 


\section{MICROORGANISMOS UTILIZADOS}

Este trabajo se ha realizado con la levadura de gemación Saccharomyces cerevisiae. Este microorganismo fue descrito por E. C. Hansen en 1838, aunque en 1680 ya se sabía que estaba presente en la cerveza. Pertenece al Phylum Ascomycota, Clase Saccharomycetes, Orden Saccharomycetales, Familia Saccharomycetaceae. La palabra Saccharomyces precede del griego y significa "hongo de azúcar", mientras que cerevisiae proviene del latín y significa "de cerveza".

En este trabajo se utilizaron diferentes estirpes de $S$. cerevisiae con distintas combinaciones de virus RNA. También se emplearon varias cepas de Escherichia coli para la amplificación y expresión de plásmidos. Todas ellas, así como su procedencia y características genéticas se recogen en la TABLA 4. Las cepas de S. cerevisiae se conservaron en YPAD 50\% - glicerol 50\% a -80드, y las cepas de E. coli se conservaron en glicerol al $30 \%$ a -80 으.

TABLA 4: Estirpes empleadas en este trabajo

\begin{tabular}{|c|c|c|}
\hline Nombre & Características & Origen \\
\hline \multicolumn{3}{|c|}{ Saccharomyces cerevisiae } \\
\hline 2928 & a ura3 his3 $\Delta 1 \operatorname{trp} 120 \mathrm{~S}$ RNA, 23S RNA-o, L-A -o, L-BC & Esteban (2003) \\
\hline 2928-4 & a ura3 his3 1 trp1. 20S RNA-o, 23S RNA-o, L-A -o, L-BC & Esteban (2005) \\
\hline 2928-5 & a ura3 his3 $\Delta 1 \operatorname{trp} 120$ S RNA-o, $23 S$ RNA, L-A -o, L-BC & Esteban (2003) \\
\hline 1101 & $\alpha$ kar1-1 his4 (KIL-K1). 20S RNA, 23 S RNA-o, L-A, L-BC & Wickner, R. B. ${ }^{\ddagger}$ \\
\hline BY4741 & a his3 $\Delta 1$ leu $2 \Delta 0$ met $15 \Delta 0$ ura3 $\Delta 0.20$ S RNA-o, 23 S RNA-o, L-A, L-BC & Revuelta, J. $L^{x}$ \\
\hline XRN1D & $\begin{array}{l}\text { a his3 } \Delta 1 \text { leu2 } \Delta 0 \text { met15 } \Delta 0 \text { ura3 } \triangle 0 \text { XRN1 }:: \text { kanMX4. 20S RNA-o, } 23 S \\
\text { RNA-o, L-A, L-BC }\end{array}$ & Revuelta, J. L ${ }^{\times}$ \\
\hline 882 & $\begin{array}{l}\text { a his3 } \Delta 1 \text { leu2 } \Delta 0 \text { met15 } \Delta 0 \text { ura3 } \Delta 0, \text { XRN1::KanMX4.Citoducido XRN1 } \\
\text { con 20S RNA. 20S RNA, } 23 \text { S RNA-O, L-A, L-BC }\end{array}$ & Este trabajo \\
\hline$S K I 2 \Delta$ & BY4741 con $S K I 2 \Delta:: K a n M X 4$. & Revuelta, J. L. ${ }^{x}$ \\
\hline SKI3 & BY4741 con SKI3A::KanMX4. & Revuelta, J. L. ${ }^{x}$ \\
\hline SKI7D & BY4741 con SKI7A::KanMX4. & Revuelta, J. L. ${ }^{*}$ \\
\hline
\end{tabular}




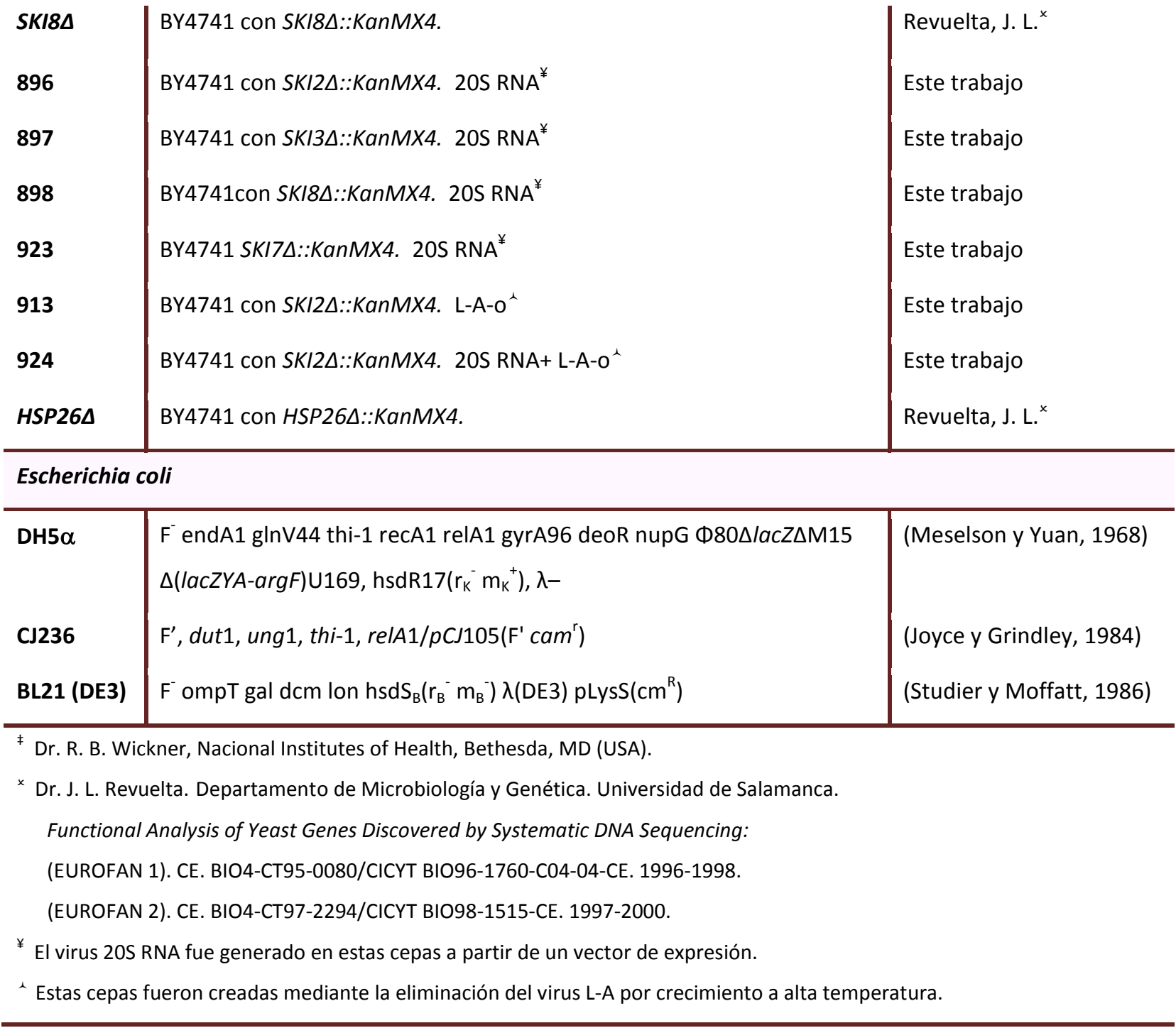

\section{MEDIOS Y CONDICIONES DE CULTIVO}

\subsection{MEDIOS EMPLEADOS}

\subsubsection{MEDIOS DE CULTIVO PARA S. cerevisiae}

Los medios de cultivo utilizados para el crecimiento de $S$. cerevisiae se describen a continuación:

YPAD (Yeast extract Peptone, Dextrose and Adenine): Extracto de levadura 1\%, peptona 2\%, glucosa $2 \%$, adenina $0.04 \%$, uracilo $0.02 \%$. Este es el medio rico estándar que se emplea para el crecimiento de S. cerevisiae. El extracto de levadura, peptona, la base nitrogenada sin aminoácidos y agar fueron 
siempre de la casa Difco, ya que los de otros proveedores afectan a la cantidad del virus 20S RNA en la célula.

YPG (Yeast extract Peptone and Glycerol): Para distinguir colonias que no tienen mitocondrias funcionales se sustituye en el medio YPAD el $2 \%$ de glucosa por glicerol al $4 \%$, ya que estas cepas son incapaces de fermentar el glicerol. Se utiliza en procesos de citoducción.

MM (Minimal Medium): Glucosa 2\%, base nitrogenada sin aminoácidos $0.7 \%$. En el medio MM sólo crecen las cepas protótrofas. Utilizado en procesos de citoducción y selección de diploides.

Medio H: Glucosa $2 \%$, base nitrogenada sin aminoácidos $0.7 \%$, adenina $0.25 \%$, uracilo $0.9 \%$, PABA $0.1 \%$, mezcla de aminoácidos deseada $0.2 \%$. El medio $\mathrm{H}$ (o medio rico) es un medio complejo que tiene todos los aminoácidos. En este medio puede crecer cualquier levadura, independientemente de sus marcadores genéticos. Para seleccionar cepas en las que se pretenda analizar auxotrofías, se preparan diferentes medios en los que se suprimen aquel(los) componente(s) (aminoácido o base nitrogenada) según la auxotrofía que se pretenda analizar. Así se prepararon, por ejemplo, medios $\mathrm{H}$-trp (sin triptófano), H-ura (sin uracilo), $\mathrm{H}$-his (sin histidina) y H-ura-trp (sin uracilo ni triptófano) entre otros.

Todos los cultivos se incubaron a $28^{\circ} \mathrm{C}$, en medio líquido con agitación a $200 \mathrm{rpm}$ o en placa. El tiempo de crecimiento de la levadura es diferente dependiendo del experimento, variando desde 4 horas para obtener cultivos en fase logarítmica (para la expresión de proteínas o transformación con plásmidos) hasta 48 horas, en las que las células alcanzan la fase estacionaria tardía de su crecimiento (para el análisis de la generación del virus 20S RNA).

\subsubsection{MEDIOS DE CULTIVO PARA E. coli}

Estos medios fueron preparados según se describe en Maniatis et al. 1984.

LB (Luria-Bertani): Bactotriptona 1\%, extracto de levadura $0.5 \%, \mathrm{NaCl} 1 \%$. Medio rico para el crecimiento de bacterias.

2xYT (Yeast extract, Tryptone): Bactotriptona 1.6\%, extracto de levadura 1\%, $\mathrm{NaCl} 1 \%$. Medio rico utilizado para obtener DNA monocatenario con uracilo a partir del fago M13K07, necesario para las mutaciones dirigidas in vitro. 
Para seleccionar los clones bacterianos resistentes a antibióticos, los medios de $E$. coli se suplementaron con Ampicilina (100 $\mu \mathrm{g} / \mathrm{ml})$ o Kanamicina $(50 \mu \mathrm{g} / \mathrm{ml})$.

E. coli se ha utilizado en este trabajo como herramienta para la clonación y amplificación de plásmidos, preparación de DNA monocatenario para las mutaciones in vitro y expresión de proteínas a partir del promotor de la RNA polimerasa del fago T7 (a partir de este momento lo designaremos sólo como T7). La temperatura de incubación de la bacteria fue de 37ํㅡ, con agitación a $200 \mathrm{rpm}$ en el caso de los cultivos líquidos, excepto la inducción de la RNA polimerasa del fago T7, que tuvo lugar a $28 \circ \mathrm{C}$ durante 5 horas.

Los medios sólidos para los dos microorganismos se prepararon con agar al $2 \%$. Todos los medios fueron preparados con agua destilada (milli-Rho), se ajustó el pH a 7.0, y se esterilizaron por calor en el autoclave.

\section{TÉCNICAS DE BIOQUÍMICA Y BIOLOGÍA MOLECULAR}

\subsection{ANÁLISIS DE ÁCIDOS NUCLEICOS}

Casi todos los protocolos utilizados para la manipulación del DNA se recogen en Maniatis (Maniatis, 1984). Además de las indicaciones generales de este manual, se tuvieron en cuenta las especificaciones de las casas comerciales suministradoras de los productos utilizados.

\subsubsection{OBTENCIÓN DE DNA PLASMÍDICO}

La extracción de DNA plasmídico a partir de bacterias se realizó utilizando el método de la lisis alcalina, en el que las células se rompen en presencia de una mezcla de $\mathrm{NaOH}$ y SDS (Dodecil sulfato sódico) (Birnboim y Doly, 1979). Cuando fue preciso utilizar DNA de mayor pureza se utilizó el kit Wizard ${ }^{\circledR}$ Plus SV Minipreps DNA purification de Promega.

\subsubsection{TRATAMIENTO ENZIMÁTICO DEL DNA}

Los principales tratamientos enzimáticos realizados fueron:

a) Digestiones con endonucleasas de restricción

Para llevar a cabo la digestión enzimática del DNA, se utilizaron las siguientes condiciones: 
Tris acetato pH $7.533 \mathrm{mM}$, Acetato de magnesio $10 \mathrm{mM}$, BSA (Seroalbúmina bovina) 0.1 $\mathrm{mg} / \mathrm{ml}$, Acetato de potasio $66 \mathrm{mM}, 1 \mathrm{mM}$ DTT (Ditiotreitol), $3 \mathrm{mM}$ Espermidina, RNAsa A $3 \mu \mathrm{g} / \mathrm{ml}$ y $0.3-0.5 \mathrm{U} / \mu \mathrm{l}$ de la endonucleasa de restricción (Promega, Fermentas). La reacción se incuba normalmente durante una hora a la temperatura indicada por el proveedor.

b) Ligación mediante la DNA ligasa del fago T4

Para unir de fragmentos de DNA en las subclonaciones (apartado 3.6) se utilizaron $0.5 \mathrm{U}$ de enzima T4 DNA Ligasa HC (High Concentrate, usb $^{\circledR}$ e Invitrogen $^{\mathrm{TM}}$ ) en $10 \mu \mathrm{l}$ de reacción que se incubó durante 2 - 3 horas a temperatura ambiente en el tampón provisto por la casa comercial.

c) Fosforilación mediante la polinucleótido quinasa del fago T4

Durante las mutaciones in vitro se fosforila el extremo $5^{\prime}$ del oligo que va a introducir la modificación en el plásmido con $2 \mathrm{U}$ de la enzima T4 Polinucleótido kinasa de Promega (Apartado 3.5).

d) Tratamiento con fosfatasa alcalina de intestino de ternera (Calf Intestine Alkaline Phosphatase, CIAP, Fermentas)

Mediante la fosfatasa alcalina, se elimina el grupo fosfato del extremo $5^{\prime}$ del vector previamente digerido con la enzima de restricción deseada. De esta manera se evita que el vector se religue durante la sublonación de un fragmento de DNA. Se utilizaron $1 \mathrm{U}$ de enzima en el tampón comercial correspondiente en un volumen final de $15 \mu \mathrm{l}$. La muestra se incuba a $37^{\circ} \mathrm{C}$ durante 30 minutos, se separa en un gel de agarosa al 1\% (Apartado 3.9) y se purifica el DNA mediante el sistema DNA extraction kit (Fermentas).

\subsection{TRANSFORMACIÓN}

\subsubsection{TRANSFORMACIÓN DE S. cerevisiae}

Para la transformación de S. cerevisiae se siguió la técnica de Ito (Ito et al., 1983), con las siguientes modificaciones:

A partir de un cultivo que ha estado creciendo toda la noche, se inocula $1 \mathrm{ml}$ en $5 \mathrm{ml}$ de medio fresco, y se incuba durante $2-2.5$ horas a 28 ํ. C. Se recogen las células por centrifugación, se lavan con $1 \mathrm{ml}$ de tampón TE (Tris pH 8.0, ácido dietilenaminotetraacético, EDTA, $1 \mathrm{mM}$ ) y se resuspenden en una solución de acetato de litio $25 \mathrm{mM}$ en el mismo tampón. Las células se incuban 
durante una hora a $28^{\circ} \mathrm{C}$ en agitación para debilitar su pared celular y hacerlas competentes. En cada transformación se utilizan $100 \mu \mathrm{l}$ de estas células a las que se añaden 2-5 $\mu \mathrm{g}$ de plásmido en un volumen máximo de $5 \mu \mathrm{l}$. Después de incubar las muestras durante 30 minutos a temperatura ambiente sin agitación se añaden $100 \mu \mathrm{l}$ de polietilenglicol 4000 (PEG) al 70\% y se mantienen de nuevo 30 minutos a temperatura ambiente. A continuación las células se someten a un choque térmico de 5 minutos a $42 \stackrel{\circ}{ } \mathrm{C}$ y para eliminar el exceso de PEG se lavan con $1 \mathrm{ml}$ de tampón TE, se centrifugan y se resuspenden en $150 \mu \mathrm{l}$ del mismo tampón. Las células se siembran en placas de medio selectivo, que se incuban a $28^{\circ} \mathrm{C}$ hasta la aparición de los transformantes ( 2 - 3 días).

\subsubsection{TRANSFORMACIÓN DE E. coli}

La transformación de cepas quimiocompetentes de E. coli con plásmidos, mezclas de ligación o mutaciones in vitro se realizó mediante el procedimiento diseñado por Hanahan basado en el choque térmico (Hanahan, 1983). En algunos casos, la transformación se realizó por un método simplificado conocido como "transformación de minuto", descrito por Golub en 1988 (Golub, 1988).

\subsection{REACCIÓN EN CADENA DE LA POLIMERASA (PCR)}

La amplificación de fragmentos de DNA mediante PCR (Polymerase chain reaction) se llevó a cabo en un termociclador Applied Biosystems 2720 Thermal Cycler $^{T M}$. Dependiendo del tamaño del fragmento a amplificar se emplearon dos condiciones diferentes:

\section{a) Fragmentos de hasta $1 \mathbf{~ k b}$}

Para amplificar el extremo 3' de las moléculas de 20S RNA en experimentos de 3' RACE así como en los que se requería amplificar pequeñas zonas de secuencias clonadas en plásmidos, se utilizó una reacción que contiene una mezcla de dNTPs $200 \mu \mathrm{M}$, los dos oligonucleótidos cebadores $1 \mu \mathrm{M}, \mathrm{MgCl}_{2} 1.5 \mathrm{mM}$, Taq DNA polimerasa (Promega) $2.5 \mathrm{U} / 100 \mu \mathrm{l}$ y el tampón de reacción suministrado con la enzima. Las condiciones se resumen en la Fig. 12.

\section{b) Fragmentos mayores de $\mathbf{1} \mathbf{k b}$}

Para amplificar fragmentos largos, como por ejemplo el gen XRN1/SKI1 (5.5 kb), a partir de DNA genómico, se utilizaron las condiciones sugeridas por Invitrogen ${ }^{\mathrm{TM}}$. En este caso, las muestas contienen $200 \mathrm{ng}$ de DNA molde, un tampón facilitado por la casa comercial ( $0.2 \mathrm{mM}$ de cada dNTP y $\mathrm{MgSO}_{4} 2 \mathrm{mM}$ ), $1 \mu \mathrm{M}$ de cada oligonucleótido cebador y $1 \mathrm{U} / 50 \mu$ l de enzima AccuPrime ${ }^{T M}$ Taq High Fidelity. 


\begin{tabular}{|c|c|c|c|c|c|}
\hline \multicolumn{2}{|l|}{ PCR (Fragmentos hasta $1 \mathrm{~kb}$ ): } & \multicolumn{4}{|c|}{ PCR (Fragmentos mayores de $\mathbf{1} \mathbf{k b}$ ) } \\
\hline Desnaturalización inicial & $3 \mathrm{~min} . \quad 95 \div \mathrm{C}$ & Desnaturalización inicial & $2 \mathrm{~min}$. & $94 \div \mathrm{C}$ & \\
\hline 1. Desnaturalización del DNA & $1 \mathrm{~min} . \quad 95^{\circ} \mathrm{C}$ & 1. Desnaturalización del DNA & A $30 \mathrm{seg}$. & $94 \div \mathrm{C}$ & \\
\hline 2. Anillamiento & $\left.1 \mathrm{~min} .50^{\circ} \mathrm{C}\right\} \times 30$ ciclos & 2. Anillamiento & $30 \mathrm{seg}$. & $64 \circ \mathrm{C}$ & X30 ciclos \\
\hline 3. Extensión & 90 seg. $70^{\circ} \mathrm{C}$ & 3. Extensión & $1 \mathrm{~min} . / \mathrm{kb}$ & $68 \div \mathrm{C}$ & \\
\hline Extensión final & $4 \mathrm{~min} . \quad 70^{\circ} \mathrm{C}$ & & & & \\
\hline
\end{tabular}

Figura 12. Condiciones empleadas en la técnica de PCR, según la longitud del fragmento a amplificar.

Cuando se requería clonar los fragmentos de DNA obtenidos por PCR, estos se purificaron a partir de geles de agarosa al $1 \%$ con el sistema comercial DNA Extraction Kit de Fermentas (apartado 3.6). Los oligonucleótidos empleados en este trabajo fueron suministrados por Isogen Lab Science y Thermo Fisher y sus secuencias se muestran en la TABLA 5 y el Anexo I.

\section{RT-PCR}

La RT-PCR (Reverse Transcription Polymerase Chain Reaction) es una técnica para amplificar mediante una reacción de PCR, una molécula de RNA. Para ello previamente se sintetiza una molécula de cDNA a partir del RNA mediante una reacción enzimática llevada a cabo por la transcriptasa reversa (SuperScript ${ }^{T M}$ /I Reverse Transcriptase, Invitrogen ${ }^{T M}$ ).

TABLA 5: Oligonucleótidos empleados en este trabajo (PCR y secuenciación)

\begin{tabular}{|c|c|c|}
\hline Nombre & Secuencia & Características \\
\hline \multicolumn{3}{|l|}{ PCR } \\
\hline RE-156 & $\begin{array}{l}\text { GACTCGAGTCGAGGATCCTTTTTTTTTTTTTTTT } \\
\text { TT }\end{array}$ & $\begin{array}{l}\text { Oligo para la síntesis del cDNA en 3' RACE. La cola } \\
\text { de poli(T) anilla en la de poli(A) añadida en el } \\
\text { extremo } 3^{\prime} \text { de } 20 \text { S RNA. }\end{array}$ \\
\hline RE-157 & GACTCGAGTAGGATCC & $\begin{array}{l}\text { Para amplificar un fragmento de } 360-380 \text { nt del } \\
\text { extremo 3' de } 20 \text { S RNA en 3'RACE junto con PG-6. }\end{array}$ \\
\hline PG-6 & 2191-CGAATCGTCGCCAGTAG-2207 & $\begin{array}{l}\text { Amplifica junto con RE-157 el extremo 3' de la } \\
\text { cadena (+) de } 20 \text { S RNA en 3' RACE. }\end{array}$ \\
\hline RE-171 & 1122-CGCTTCTGCGATCGTAGATG-1141 & $\begin{array}{l}\text { Amplifica con ALI-3 un fragmento de } 842 \text { nt de la } \\
\text { zona central de } 20 \text { S RNA en la que se encuentra el } \\
\text { sitio Smal de pRE } 805 \text {. }\end{array}$ \\
\hline ALI-3 & 1946-TAAAACTGTATGCAGCAG-1963 & $\begin{array}{l}\text { Amplifica la zona central de } 20 S \text { RNA junto con } \\
\text { RE-171. }\end{array}$ \\
\hline RE-296 & AATTAGGATCCCAGTACGGTATGGGTATTC & $\begin{array}{l}\text { Amplifica por PCR la ORF del gen } X R N 1 \text { de } S \text {. } \\
\text { cerevisiae }(4.6 \mathrm{~kb}) \text { junto con RE- } 297 \text {. }\end{array}$ \\
\hline
\end{tabular}




\begin{tabular}{|c|c|c|}
\hline RE-297 & AATTAGGATCCGTCGTATGTTCTAAGTAGA & Amplifica por PCR la ORF del gen $X R N 1$ de $S$. \\
\hline RE-298 & AATTAGGATCCAATCCAAACATTGTGCCCAC & $\begin{array}{l}\text { Amplifica por PCR el gen XRN1 (parte 5'). El } \\
\text { fragmento amplificado }(5.5 \mathrm{~kb}) \text { incluye el } \\
\text { promotor del gen y las señales de terminación de } \\
\text { la transcripción. }\end{array}$ \\
\hline RE-299 & AATTAGGATCCGGTTTGCTAAGCAAAATGAG & $\begin{array}{l}\text { Amplifica por PCR el gen XRN1 (parte } 3^{\prime} \text { ) junto } \\
\text { con RE-298. }\end{array}$ \\
\hline \multicolumn{3}{|c|}{ Secuenciación } \\
\hline RE-79 & TACTCGTTTTAGGACTGG & $\begin{array}{l}\text { Para secuenciar el extremo 3' de } 20 \mathrm{~S} \text { RNA. Anilla } \\
\text { en el vector a } 170 \mathrm{nt} \text { del extremo del cDNA. Se } \\
\text { utilizó rutinariamente para comprobar los } \\
\text { cambios introdicidos en el extremo mediante } \\
\text { mutaciones in vitro. }\end{array}$ \\
\hline TW-1 & 374-GAGAACTCCTTCGCAGAA-357 & Sirve para secuenciar el extremo 5' de 20S RNA. \\
\hline
\end{tabular}

\subsection{3' RACE}

Utilizamos la técnica de 3' RACE (3' Rapid Amplification CDNA Ends) para amplificar el extremo 3' de una molécula de RNA. Esta técnica se ha empleado para conocer la secuencia de este extremo del genoma en los virus generados a partir de plásmidos a los que previamente se les habían introducido modificaciones en su extremo. La técnica consta de los siguientes pasos:

\section{Aislamiento del RNA total de S. cerevisiae (Ver apartado 3.8)}

\section{Adición de una cola de poli(A) en el extremo 3' del RNA}

$2.5 \mu \mathrm{l}$ de RNA total se tratan con la enzima poliA polimerasa (Invitrogen ${ }^{\mathrm{TM}}$ ) en presencia de Tris $\mathrm{HCl}$ pH 8.050 mM, MgCl 10 mM, MnCl 2.2 mM, NaCl 125 mM, ATP 0.25 mM, BSA $0.25 \mu \mathrm{g} / \mu \mathrm{l} \mathrm{y}$ $2.5 \mathrm{U} / \mu \mathrm{l}$ de la enzima (volumen total de $50 \mu \mathrm{l}$ ) a $37{ }^{\circ} \mathrm{C}$ durante 30 minutos. Durante este tiempo se incorporan aproximadamente 20-40 adeninas en el extremo 3'. Después la muestra se procesa ${ }^{*}$ realizando una extracción con fenol:cloroformo y otra con coloformo:alcohol isoamílico, el RNA se precipita, se lava con etanol al 70\%, se seca y resuspende en $10 \mu \mathrm{l}$ de agua estéril.

\section{Retro-transcripción del RNA en DNA}

$5 \mu \mathrm{l}$ del RNA poliadenilado se desnaturaliza con hidróxido de metilmercurio $10 \mathrm{mM}$ durante 10 minutos a temperatura ambiente. A continuación se incuba 5 minutos con $\beta$-mercaptoetanol 100 mM (para quelar los iones mercurio y estabilizar la transcriptasa reversa) y 4 unidades de RNAsin (RNAse Inhibitor, Promega). Mediante la enzima Superscript Reverse Transcriptase RNAse H- 
(Invitrogen ${ }^{\mathrm{TM}}$ ) se sintetiza el cDNA complementario utilizando un oligo-d(T) (RE-156) que anilla con la cola de poli(A), y que además lleva fusionada una secuencia de 18 nucleótidos, entre los cuales hay un sitio BamHI importante para clonar posteriormente el fragmento amplificado. Esta reacción tiene lugar durante 90 minutos a 45 ํㅡ, en el tampón suplementado por la casa comercial de la transcriptasa reversa y DTT $10 \mathrm{mM}$ (volumen final $14.5 \mu \mathrm{l}$ ). Se añade agua milli-Q, EDTA $5 \mathrm{mM}$ y RNAsa A $0.1 \mu \mathrm{g}$ (volumen final $100 \mu \mathrm{l}$ ) y se incuba a $37^{\circ} \mathrm{C}$ durante 15 minutos para eliminar el RNA de la muestra. El DNA se procesa realizado dos extracciones con fenol:cloroformo y se precipita tal y como se hizo en el paso anterior. Una vez seca, la muestra se resuspende en $50 \mu l$ de agua estéril milli-Q. Para que el oligo introducido en la reacción de retrotranscripción no interfiera en la reacción de PCR posterior, este se elimina de la muestra pasándola por una columna mini Quick Spin Oligo G-50 (Roche).

\section{PCR para amplificar el extremo $3^{\prime}$ de las moléculas}

Para amplificar el extremo 3' del cDNA, utilizamos los oligos RE-157 (anilla en la zona extra de 18 nt que introdujo RE-156 durante la retrotranscripción) y PG-6 para hacer una reacción de PCR según las condiciones descritas en el apartado 3.3a.

\section{Clonar el fragmento amplificado en un plásmido pBluescript KS+}

El fragmento amplificado se digiere con BamHI y otra enzima adecuada para clonar el DNA en un plásmido pBluescript KS+ (Apartado 4.1). Después de la ligarlos se transforma en la cepa de E. coli DH5 $\alpha$. Normalmente se secuencia con el oligo reverso (Anexo I) el DNA extraído de 8-10 transformantes independientes para que el resultado obtenido sea representativo de la composición de los extremos 3' de la población viral de partida.

* Procesar la muestra: en todos los experimentos en los que se desean obtener ácidos nucleicos (tanto DNA como RNA) las muestras se limpian siguiendo los siguientes pasos:

a) Extracciones 1:1 que pueden ser con fenol, fenol:cloroformo (50:48:2 de fenol, cloroformo y alcohol isoamílico) o cloroformo:alcohol isoamílico (96:4). Todos los productos son de Merck ${ }^{\circledR}$. La muestra se mezcla vigorosamente con la solución orgánica, se centrifuga durante 5 minutos a $16.300 \mathrm{xg}$, generalmente a temperatura ambiente, salvo la extracción con fenol cuando se trabaje con RNA que es a 4 으, y se extrae la fase acuosa, donde está la muestra. Siempre que se indique una centrifugación en los Materiales y Métodos, tendrá lugar a $16.300 \mathrm{xg}$ salvo que se indique lo contrario. 
a) Precipitación: con acetato de sodio pH $5.50 .3 \mathrm{M}$ y 2.5 volúmenes de etanol puro (100\%, Merck ${ }^{\circledR}$ ), seguido de una centrifugación generalmente de 5 minutos a temperatura ambiente, aunque cuando la cantidad de DNA/RNA es muy pequeña es de 15 minutos a 4 으.

b) Lavado: con etanol al 70\% seguido de una centrifugación durante 5 minutos a temperatura ambiente para eliminar sales.

c) Secado: en una centrífuga conectada a una bomba de vacío (Speed Vac Concentrator, Savant).

d) Resuspender: en el volumen adecuadop para cada experimento en agua milli-Q estéril el RNA, o tampón TE el DNA.

\subsection{MUTAGÉNESIS DIRIGIDA in vitro}

La técnica empleada en este trabajo para realizar mutaciones in vitro sobre un plásmido se basa en el método descrito por Kunkel (Kunkel, 1985). Podemos dividir la técnica en tres partes:

\section{a) Obtención del DNA monocatenario}

En primer lugar, se transforma la cepa de E. coli CJ236 con el plásmido que se desea modificar. Esta cepa tiene las siguientes características:

- $\quad$ El episoma F' le permite ser infectada por el fago auxiliar M13K07

- La mutación dut inactiva la enzima dUTPasa. Cuando existen elevados niveles intracelulares de dUTP, las moléculas de DNA sintetizadas tienen uracilo en los lugares en los que debería haber timina.

- $\quad$ La mutación ung inactiva la uracilo N-glicosilasa, de forma que el uracilo incorporado al DNA no puede ser eliminado

3 - 4 transformantes se inoculan en $5 \mathrm{ml}$ de medio 2 XYT suplementado con el antibiótico cuya resistencia porta el plásmido y las células se infectan con el fago filamentoso M13K07 (1.5×10 $0^{10}$ ufp) durante 5 horas a $37{ }^{\circ} \mathrm{C}$ en agitación. Después se añaden $50 \mu \mathrm{g} / \mu \mathrm{l}$ de kanamicina y se incuba el cultivo toda la noche a $37{ }^{\circ} \mathrm{C}$ para que sólo se mantengan las células infectadas por el fago, ya que es el que porta la resistencia al antibiótico.

El cultivo se centrifuga, se deshechan las células y al sobrenadante se le añade PEG 8000 $20 \%-\mathrm{NaCl} 0.33 \mathrm{M}$. Después de mezclar vigorosamente, la muestra se deja a temperatura ambiente durante 20 minutos para que los fagos que contienen el Uss-DNA se concentren en el tubo. Después de centrifugar durante 5 minutos el precipitado se resuspende en $600 \mu \mathrm{l}$ de SDS 0.3\% en tampón TE. La muestra se procesa realizando una extracción con fenol, una con fenol:cloroformo y otra con 
cloroformo:alcohol isoamílico. Después de precipitar y lavar el DNA, se seca y resuspende en $30 \mu \mathrm{l}$ de tampón TE. El Uss-DNA se analiza en un gel de agarosa para comprobar la cantidad obtenida.

\section{b) Fosforilación del oligonucleótido que contiene la modificación}

La fosforilación se realiza incubando durante una hora a 37 으 0.5 nmoles de oligo proporcionado por Isogen Lab Science o Thermo-Fisher con 2 unidades de la enzima polinucleótido kinasa del fago T4 de Promega en $25 \mu$ de tampón 1x proporcionado por la casa comercial. Una vez concluída la reacción, la muestra se procesa extrayéndola con fenol:cloroformo y cloroformo:alcohol isoamílico y finalmente se resuspende en $25 \mu$ l de tampón TE.

\section{c) Mutación in vitro}

La mutagénesis dirigida consta de dos reacciones, anillamiento del oligo al Uss-DNA purificado a partir del fago M13 y síntesis de la cadena complementaria al DNA a partir del oligo que contiene el cambio deseado.

- Anillamiento: $3 \mu \mathrm{l}$ de Uss-DNA se desnaturaliza en presencia de 1 pmol de oligo fosforilado y de tampón de anillamiento (Tris $\mathrm{HCl} 20 \mathrm{mM} \mathrm{pH} \mathrm{7.4,} \mathrm{MgCl}_{2} 2 \mathrm{mM}, \mathrm{NaCl} 50 \mathrm{mM}$ ) durante 3 minutos a $75-80^{\circ} \mathrm{C}$. Para favorecer el anillamiento se deja que la temperatura hasta los 30 35 ㄷ C durante al menos 30 minutos.

- Síntesis de la nueva hebra de DNA: A la mezcla anterior se añade en tampón de síntesis (dATP 0.5 mM, dCTP 0.5 mM, dGTP 0.5 mM, dTTP 0.5 mM, ATP 1 mM, Tris HCl pH 7.410 $\mathrm{mM}, \mathrm{MgCl}_{2} 5 \mathrm{mM}$, DTT $2 \mathrm{mM}$ ) $3 \mathrm{U}$ de T7 DNA polimerasa y $1 \mathrm{U}$ de T4 DNA ligasa (todos los estos productos de $\left.u s b^{\circledR}\right)$. En algunos casos se utilizaron 0.5 - $2.5 \mu$ g proteína del gen 32 del fago T4 para favorecer la mutación. La mezcla se incuba durante 5 minutos en hielo, 5 minutos a temperatura ambiente y 90 minutos a $37^{\circ} \mathrm{C}$ para que tenga lugar las reacciones de polimerización y ligación de los extremos de las moléculas sintetizadas.

\section{d) Transformación en E. coli y análisis del resultado}

Finalmente el nuevo DNA sintetizado se introduce en la cepa $\mathrm{DH} 5 \alpha$ de E. coli para su amplificación. Esta cepa es DUT+ UNG+, por lo que las cadenas que contienen uracilo son degradadas y se replican principalmente las sintetizadas in vitro con la mutación deseada. Por último se secuencia el DNA de las colonias obtenidas para comprobar si el plásmido ha incorporado la mutación.

Los oligos empleados para realizar las mutaciones in vitro, así como los plásmidos obtenidos están recogidos en las TABLAS 2 y 3 del Anexo I. 


\subsection{SUBCLONACIÓN DE FRAGMENTOS DE DNA}

Las técnicas básicas de clonación molecular se han realizado de acuerdo a los protocolos descritos en Maniatis et al. (1984).

\subsection{SECUENCIACIÓN DE ÁCIDOS NUCLEICOS}

La técnica usada se basa en la descrita por Sanger pero empleando dideoxinucleótidos marcados con fluorocromos y un láser capaz de reconocer sus distintos colores, que corresponden a cada una de las bases del DNA (Sanger et al., 1977). Se utilizó un secuenciador 3100 Genetic Analyzer (Aplied Biosystems ${ }^{\circledR}{ }_{-}$HITACHI). Las secuencias se analizaron mediante el programa 4Peaks, que muestra el cromatograma de la reacción y la secuencia correspondiente.

El fundamento de este sistema es una reacción de PCR en la cual la extensión enzimática de una cadena de DNA es interrumpida por la incorporación de dideoxinucleótidos. Los oligonucleótidos empleados para la secuenciación se resumen en la TABLA 5.

Esta técnica fue llevada por el Servicio de Secuenciación de ADN de la Universidad de Salamanca.

\subsection{EXTRACCIÓN Y CONCENTRACIÓN DE RNAs}

\subsubsection{ANÁLISIS DE 20S RNA EN S. cerevisiae: CONDICIONES EXPERIMENTALES}

Dado que una gran parte de este trabajo trata sobre la generación de 20S RNA a partir de vectores de expresión y los experimentos de genética reversa llevados a cabo con este sistema, a continuación se describen en detalle las condiciones experimentales empleadas. Éstas se han utilizado tanto para el análisis de la generación del virus, como para comprobar la presencia de $20 \mathrm{~S}$ RNA en cepas de $S$. cerevisiae.

Una vez obtenidos los transformantes de S. cerevisiae con el plásmido de expresión de $20 \mathrm{~S}$ RNA, varios de ellos (6 - 8) se pasan a una placa de medio selectivo para el mantenimiento del plásmido. Normalmente se inoculan 3 - 4 transformantes en $2 \mathrm{ml}$ del mismo medio. Las células crecen a $28^{\circ} \mathrm{C}$ durante 48 horas y a continuación se recogen, se lavan con agua milli-Q estéril y se resuspenden en $2.5 \mathrm{ml}$ de acetato de potasio (KAc) 1\% pH 7.0. Después de otras 16 horas de incubación se recogen las células para preparar el RNA viral. Durante el tiempo en el que las células 
están en KAc $1 \%$ se produce un gran acúmulo del virus, por lo que denominamos a esta fase Inducción de 20S RNA.

Las células se recogen y se resuspenden en $100 \mu \mathrm{l}$ de tampón de lisis (Tris-HCl 50 mM pH 8.0, $\mathrm{NaCl} 100 \mathrm{mM}$ ) y se rompen mecánicamente con bolas de vidrio (Sartorius, $\varnothing 0.40-0.60 \mathrm{~mm}$ ). La rotura tiene lugar a 4ํㅡ en una Fast-Prep P120 (Bio 101 Savant), usando dos pulsos de 15 segundos con velocidad 4.5, enfriando las muestras en hielo durante 1 minuto entre pulso y pulso. Cuando se quiere ejercer menos fuerza sobre las células, en vez de utilizar la Fast-Prep p120, las células se rompen manualmente con vórtex a intervalos de 15 segundos, enfriando en hielo 1 minuto, 10 veces. Una vez rotas las células, se extrae el lisado mediante la adición de $400 \mu \mathrm{l}$ de tampón de lisis y una breve centrifugación (2 segundos).

A continuación se realiza una extracción con fenol a $4^{\circ} \mathrm{C}$ y dos con fenol:cloroformo. Los ácidos nucleicos presentes en la muestra se precipitan con etanol en presencia de $\mathrm{NaAc} 0.3 \mathrm{M}$, se lavan, secan y se resuspende la muestra en $50 \mu \mathrm{l}$ de agua milli-Q estéril. Para visualizar el RNA de la muestra normalmente se utilizan $2 \mu \mathrm{l}$ de la preparación y se analizan en un gel de agarosa 1.3\% (Ver apartado 3.9). El genoma del virus 20 S RNA es perfectamente visible entre los rRNAs de S. cerevisiae $25 S$ y $18 \mathrm{~S}$ (Fig. 13). Gracias a este sencillo método, podemos ver si una cepa tiene o no el virus, aunque habitualmente se confirma mediante Northern Blot (Apartado 3.10).

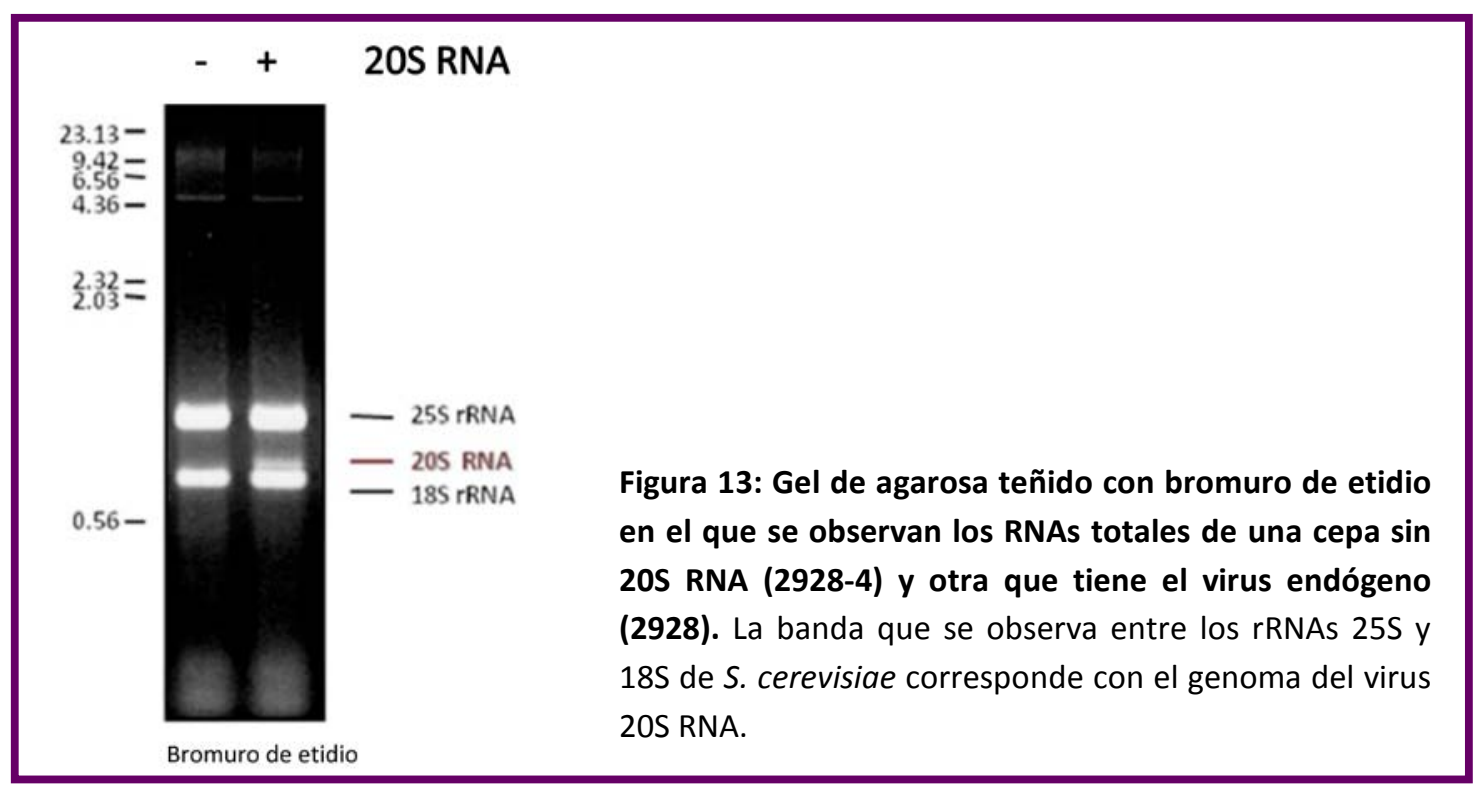

En los experimentos en los que se genera 20S RNA en S. cerevisiae es importante eliminar el plásmido de expresión para comprobar que el virus generado es autónomo y sólo depende de sí mismo para replicarse y mantenerse en la célula. Para ello "curamos" el plásmido, es decir, lo eliminamos mediante crecimiento de las células transformadas en medio rico. Al carecer de presión 
de selección, el plásmido se pierde a cabo de varias generaciones y esto se comprueba fácilmente, ya que las células no crecen en medio selectivo para la auxotrofía que portaba el vector.

\subsubsection{RNA TOTAL DE E. coli}

Las células E. coli se resuspenden en solución de lisis (Tris HCl pH 8.020 mM, NaCl 100 mM, Bentonita $0.1 \%$, inhibidor de proteasas $1 \times$ (GE-Healthcare $\left.{ }^{\circledR}\right)$, lisozima $1 \mathrm{mg} / \mathrm{ml}$ ) se añaden bolitas de vidrio (Sartorius $\varnothing 0.25-0.30 \mathrm{~mm}$ ), y se rompen en una Fast Prep P120 (Bio 101 Savant), empleando un pulso de 15 segundos a velocidad 4.5. El lisado se recoge en solución de lisis y se centrifuga durante 5 minutos a 4 ํㅡ. La muestra en este momento puede destinarse al análisis de proteínas, añadiendo tampón de carga, o del RNA total procesando la muestra de igual manera que en el caso del RNA de S. cerevisiae.

\subsection{SISTEMAS ELECTROFORÉTICOS PARA EL ANÁLISIS DE ÁCIDOS NUCLEICOS}

El análisis de los fragmentos de DNA o RNA se llevó a cabo mediante eletroforesis en geles de agarosa con baja electroendomosis (EEO) (Pronadisa) al 1\% para DNA y al 1.3\% para RNA. Estos geles llevan bromuro de etidio a una concentración final de $0.5 \mu \mathrm{g} / \mathrm{ml}$ para poder visualizar los ácidos nucleicos tras iluminarlos con una fuente de luz ultravioleta a $260 \mathrm{~nm}$. El tampón utilizado tanto para preparar la agarosa como para realizar la electroforesis fue TAE 1x (Tris acetato $40 \mathrm{mM}$, EDTA $1 \mathrm{mM} \mathrm{pH} \mathrm{8.0).}$

\subsection{HIBRIDACIÓN DE ÁCIDOS NUCLEICOS: DETECCIÓN DE RNA (Northern Blot)}

El Northern Blot es una técnica de Biología Molecular desarrollada por Alwine en 1977 que permite la detección de moléculas de RNA mediante su separación en un gel de agarosa seguida de su transferencia a una membrana de nylon o nitrocelulosa (Alwine et al., 1977). La detección de las moléculas de RNA se realiza con una sonda específica de la secuencia que se desea detectar marcada con ${ }^{32} \mathrm{P}$. En este trabajo se utilizaron las condiciones descritas por Fujimura et al. en 1990 (Fujimura et al., 1990). Las muestras se separan en condiciones nativas en un gel de agarosa y

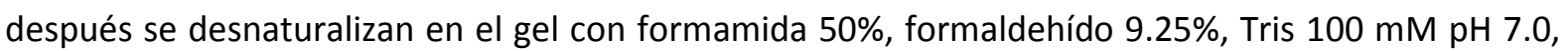
EDTA $1 \mathrm{mM}$ durante 30 minutos a 55ㅇ C antes de transferirlas a la membrana (Amersham/GEHealhcare ${ }^{\circledR}$ ) por capilaridad en una solución SSC 10\% (Sodio salino citrato). 
Las sondas específicas de RNA se obtuvieron a partir de plásmidos derivados del pBluescript KS+ (Apartado 4) en los que está clonada la secuencia de la sonda, flanqueada por los promotores de las RNAs polimerasas de los fagos T7 y T3. Una vez digerido el plásmido con la enzima de restricción adecuada, se lleva a cabo una reacción de transcripción in vitro, en la que se añaden los nucleótidos ATP, CTP y GTP $1 \mathrm{mM}$, UTP $0.1 \mathrm{mM}$, BSA $0.5 \mathrm{mg} / \mathrm{ml}$, DTT $5 \mathrm{mM}$ y $5-10 \mu \mathrm{Ci}$ del isótopo radiactivo [ $\alpha$ ${ }^{32}$ P]-UTP (Amersham y Perkin Elmer ${ }^{\circledR}$, actividad específica $3000 \mathrm{Ci} / \mathrm{mmol}$ ). Se emplea la RNA polimerasa correspondiente (Promega) para sintetizar in vitro transcritos complementarios al RNA que se desea detectar. Esto nos permite obtener sondas de una u otra polaridad dependiendo de la RNA polimerasa empleada. La reacción tiene lugar a 37으 C durante una hora. Posteriormente se procesa la muestra y se resuspende en $50 \mu \mathrm{l}$ de agua milli-Q estéril. Para medir la radiactividad incorporada se precipita un microlitro de la sonda con TCA (Ácido tricloroacético) al 10\% en presencia de $25 \mu \mathrm{g}$ de DNA de alto peso molecular como transportador. Después de 10 minutos en hielo se filtra a través de filtros GF/B (Whatman ${ }^{T M}$ ), se lava con TCA al $2 \%$ y etanol y la radiactividad se mide en un contador de centelleo Wallac 1409. Las sondas empleadas en este trabajo tienen una media de $250.000 \mathrm{cpm} / \mu \mathrm{l}(0.1 \mu \mathrm{Ci})$.

La prehibridación de la membrana se llevó a cabo en una solución de formamida 50\%, SSPE 5x ( $\mathrm{NaCl} 750 \mathrm{mM}, \mathrm{NaH}_{2} \mathrm{PO}_{4} \times \mathrm{H}_{2} \mathrm{O} 50 \mathrm{mM}$, EDTA $5 \mathrm{mM}$ ), Solución Denhardt 5x, SDS 0.1\%, DNA fragmentado $0.1 \mathrm{mg} / \mathrm{ml}$, durante 3 horas a 55 으, mientras que la hibridación tuvo lugar en formamida 50\%, SSPE 5x, Solución Denhardt 2.5x, SDS 0.1\%, DNA fragmentado $0.25 \mathrm{mg} / \mathrm{ml}$ y 6 x $10^{5}$ $\mathrm{cpm} / \mathrm{ml}$ de sonda durante toda la noche a 55ㅇ. Para lavar las membranas de los restos de radioisótopo no unido, se realizaron dos lavados de 20 minutos a temperatura ambiente en una solución SSPE 6x, SDS 1\%, un lavado de 20 minutos a temperatura ambiente en una solución SSPE 1x, SDS 1\%, y una hora con esta última solución a 60 ㄷ. Las membranas se expusieron en casetes de autorradiografía en los que se utilizaron películas fotográficas Hyperfilm ${ }^{T M} M P\left(G E-H e a l\right.$ thcare $\left.{ }^{\circledR}\right)$ para ver el resultado, o en casetes especiales de Fosforimager (Personal Molecular Imager, Bio Rad ${ }^{\circledR}$ ) cuando quisimos cuantificar la señal.

\subsection{ANÁLISIS DE PROTEÍNAS}

\subsubsection{EXTRACTOS PROTEICOS DE S. cerevisiae}

Para el análisis de las proteínas de $S$. cerevisiae se utilizaron células en dos estados metabólicos diferentes: 
a) Células en fase logarítmica: Para analizar los complejos ribonucleoproteicos formados por p91 y un RNA con la ribozima modificada en el plásmido de expresión (transcrito con secuencia extra en su extremo 3', apartado 1.2 de Resultados) las células se recogieron en fase logarítmica, ya que es el momento en el que la transcripción del RNA a partir del vector y la síntesis de proteínas es más activa. La polimerasa procede de la traducción de los transcritos generados a partir del plásmido, no de la traducción del genoma viral, por lo que estas son las condiciones óptimas para detectar la polimerasa y los transcritos. Para ello, se inocula $1 \mathrm{ml}$ de un cultivo que ha crecido la noche anterior en $3 \mathrm{ml}$ de medio fresco. Después de 4 horas a $28^{\circ} \mathrm{C}$ en agitación se recogen las células, y se procede a su rotura según se describe en el apartado 3.8.1 hasta la obtención del lisado limpio.

b) Células inducidas: Para el análisis de p91 en células que no tienen problemas para generar el virus. Las condiciones de inducción favorecen la replicación de 20S RNA, generando a su vez gran cantidad de p91. Se utiliza el mismo extracto que se destina al análisis de los RNAs.

Una vez obtenidos los extractos celulares se añade tampón de carga para proteínas a una concentración final Tris $\mathrm{HCl} 10 \mathrm{mM}$ pH 7.5, DTT 0.02 M, SDS 1\%, Glicerol 10\%, azul de bromofenol $0.005 \%$ a la muestra y se guarda a -20 으 hasta su análisis.

En algunos casos el experimento requiere concentrar las proteínas:

Análisis de proteínas procedentes de las fracciones de un gradiente de glicerol (Apartado 3.14).

Se añade TCA a una concentración final del 10\% y después de incubar la muestra 30 minutos en hielo se centrifuga durante 5 minutos a 4 으. El pellet se lava con TCA $0.2 \%$ y se resuspende en tampón de carga 1x. Si se observa un descenso de pH en la muestra (el azul de bromofenol presente en el tampón cambia de azul a amarillo) hay que neutralizar la muestra con $1 \mu$ l de tampón Tris- $\mathrm{HCl}$ $\mathrm{pH} 8.0$.

Análisis de proteínas procedentes de una inmunoprecipitación (Apartado 3.15.2)

Añadir acetona hasta un volumen final de $1.5 \mathrm{ml}$. Se centrifugan las muestras durante 15 minutos a 4ํㅡ después de haberla incubado en hielo durante 30 minutos. Secar las muestras al vacío y resuspenderlas en tampón de carga $1 \mathrm{x}$. 


\subsubsection{EXTRACTOS PROTEICOS DE E. coli}

Para el análisis de proteínas de $E$. coli se utilizan los mismos extractos celulares que se emplean para la obtención de RNA antes de ser tratados con fenol (Apartado 3.8.2). La cuantificación de la cantidad de proteínas totales tanto en S. cerevisiae como en E. coli se realizó mediante el método de Bradford (Bradford, 1976).

\subsection{SISTEMAS ELECTROFORÉTICOS PARA EL ANÁLISIS DE PROTEÍNAS}

Antes de analizar las muestras, éstas se desnaturalizan durante 2 minutos a $95 \circ \mathrm{C}$ y se centrifugan durante 1 minuto. Las proteínas se separan en geles Mini-PROTEAN3 ${ }^{\circledR}\left(\right.$ Bio-Rad $\left.^{\circledR}\right)$ de distinto porcentaje de poliacrilamida (7.5, 10 ó 14\%) en condiciones desnaturalizantes (SDS-PAGE) a una intensidad de $30 \mathrm{~mA}$ por gel. El tampón utilizado es Tris/Glicina (24.8 mM/192 mM), SDS 0.1\% pH 8.3 (Laemmli, 1970).

Una vez finalizada la electroforesis, se procede al análisis de los geles, tiñendolos para observar las proteínas totales presentes en las muestras o transfiriéndolos a una membrana de nitrocelulosa para posteriormente detectar una proteína específica mediante anticuerpos en un ensayo Western Blot.

\subsubsection{TINCIÓN DE GELES DE ACRILAMIDA}

a) Tinción con azul de Coomassie

El azul brillante de Coomassie R-250 es un colorante que se une a proteínas estequiométricamente, de manera que su cantidad puede cuantificarse. El gel se sumerge en una solución Coomassie Brilliant Blue (Bio $\mathrm{Rad}^{\circledR}$ ) 0.1\%, 2-Propanol 2.5\%, ácido acético 10\% durante una hora a temperatura ambiente y a continuación se elimina el colorante no unido mediante varios lavados con una solución metanol 50\%, ácido acético $10 \%$.

\section{b) Tinción con plata}

Este tipo de tinción permite detectar desde 0.3 - 10 ng de proteína gracias a la unión de los iones plata a las cadenas laterales de los aminoácidos seguida de la reducción de la plata, que aparece en el gel como una banda oscura. La intensidad de las bandas en este caso no depende sólo de la cantidad de proteína, sino de la cantidad de grupos sulfato que tenga cada proteína de la muestra (Switzer et al., 1979). Este tipo de tinción se ha empleado en este trabajo para visualizar p91. Para ello se han combinado dos protocolos diferentes con el fin de obtener el mejor resultado. 
1. Fijación de las proteínas: Incubación de 30 minutos en cada una de las siguientes soluciones: Solución I: Metanol 50\% Ácido acético 10\%

Solución II: Metanol 5\% Ácido acético 7\%

Solución III: Glutaraldehído 5\%

2. Varios lavados con agua milli-Q.

3. Reducción de puentes disulfuro con DTT $0.25 \mathrm{mM}$.

4. Protocolo recomendado en el kit Silver Stain Plus (Bio Rad $\left.^{\circledR}\right)$ (Gottlieb y Chavko, 1987).

Una vez finalizada la tinción de los geles, estos se secaron entre dos hojas de celofán o en un secador de geles (Gel Dryer, Bio $\left.\operatorname{Rad}^{\circledR}\right)$.

\subsubsection{WESTERN BLOT}

Después de la electroforesis las proteínas se transfieren desde el gel a una membrana de nitrocelulosa (Amersham/GE-Healthcare ${ }^{\circledR}$ ) mediante un sistema Mini Trans Blot Cell (Bio-Rad $\left.{ }^{\circledR}\right)$, usando como tampón CAPS 10 mM (Ácido $N$-ciclohexil-3-aminopropansulfonico) en frío durante una hora a $270 \mathrm{~mA}$. A partir de este momento para simplificar denominaremos a esta técnica simplemente Western, y al Northern Blot, Northern.

Inmunodetección de proteínas:

Las membranas se bloquean en tampón TBST (Tris-HCl 20 Mm pH 7.6, NaCl 137 mM y 0.1\% Tween 20) con BSA al 3\% durante una hora a temperatura ambiente. Posteriormente las membranas se incuban con el anticuerpo primario a la dilución apropiada en TBST durante 1 hora. Después de lavar 3 veces durante 5 minutos con abundante TBST, la membrana se incuba con un anticuerpo secundario anti-IgG (Anticuerpo monoclonal de conejo (Amersham/GE-Healthcare ${ }^{\circledR}$ ), dilución 1: 5000) unido a peroxidasa de rábano (HRP, horseradish peroxidase) durante 45 minutos a temperatura ambiente. Las membranas se vuelven a lavar y se añade el sustrato para la detección de la actividad peroxidásica por quimioluminiscencia, para ello se empleó el kit $E C L^{\circledR}$ (Amersham/GEHealthcare ${ }^{\circledast}$ ). Las proteínas reconocidas por los anticuerpos se detectan exponiendo la membraba a películas Hyperfilm ${ }^{T M}$ MP (Amersham/GE-Healhcare ${ }^{\circledR}$ ). Para cuantificar la cantidad de proteína detectada se utilizó un lector de quimioluminiscencia $\operatorname{ChemiDoc}^{\circledR}\left(\right.$ Bio-Rad $\left.^{\circledR}\right)$

Los anticuerpos primarios utilizados en este trabajo han sido:

- $\quad$ Antisuero policlonal frente al extremo carboxi-terminal de p91. Dilución 1:5000 (Solórzano et al., 2000).

- $\quad$ Antisuero policlonal frente a la GFP. Dilución 1: 2500 (Solórzano, 2001). 


\subsection{PURIFICACIÓN PARCIAL DE COMPLEJOS RIBONUCLEOPROTEICOS p91/20S RNA}

Uno de los objetivos de este trabajo es el estudio de los complejos ribonucleoproteicos p91/20S RNA. En estos experimentos se emplean unas condiciones diferentes de crecimiento: las cepas a analizar se inoculan en $40 \mathrm{ml}$ de medio $\mathrm{H}$ y se incuban a $28^{\circ} \mathrm{C}$ en agitación durante 48 horas. Las células se recogen y se reuspenden en $100 \mathrm{ml}$ de KAc $1 \%$. Después de 16 horas a 28 으 se recogen y se separan en 4 tubos de $1.5 \mathrm{ml}$ para facilitar su manipulación. Se rompen en una Fast-Prep, empleando las mismas condiciones descritas en el apartado 3.8.1. Una vez rotas las células se extrae el lisado y se centrifuga durante 5 minutos a 4 ํㅡ. Eliminados los restos celulares, se combinan los lisados procedentes de los cuatro tubos y se realizan una serie de ultracentrifugaciones diferenciales para limpiar los complejos p91/20S RNA del resto de componentes subcelulares. Estas tuvieron lugar en una centrífuga Optima ${ }^{T M} T L X$ Ultracentrifugue (Beckman-Coulter). Para eliminar membranas y otros restos de elementos pesados, como la mayoría de los ribosomas, se realiza una primera centrifugación a $55.000 \mathrm{rpm}(107.400 \mathrm{xg})$ en un rotor TLA-100.2 a 4으 durante 30 minutos. El sobrenadante se centrifuga de nuevo, esta vez en un rotor TLA-100.3 a $75.000 \mathrm{rpm}(238770 \mathrm{xg})$ durante dos horas a 4 으 y el precipitado se resuspende en $500 \mu \mathrm{l}$ de tampón de lisis. Con esta segunda centrifugación se sedimentan los complejos (así como las proteínas que los puedan acompañar) y se eliminan en el sobrenadante la gran mayoría de las proteínas solubles presentes en la célula.

\subsection{GRADIENTES CONTINUOS DE GLICEROL}

Con el fin de separar los complejos ribonucleoproteicos de otros componentes celulares (mayoritariamente ribosomas) se centrifugó la muestra en un gradiente lineal de glicerol del $10 \%$ al 40\% en una solución Tris $\mathrm{HCl}$ pH $8.010 \mathrm{mM}, \mathrm{NaCl} 0.1 \mathrm{M}, \mathrm{MgCl}_{2} 30 \mathrm{mM}$, heparina $100 \mu \mathrm{g} / \mathrm{ml}$. El gradiente se prepara con 12 horas de antelación y se guarda a $4^{\circ} \mathrm{C}$ para que se estabilice. La muestra enriquecida de complejos p91/20S RNA obtenida en el apartado 3.13 se desposita en el gradiente y se centrifuga a $24.000 \mathrm{rpm}(76221 \mathrm{xg})$ durante 18 horas a 4 으 en un rotor sw28Ti (centrífuga Optima $^{T M}$ L-80 XP (Beckman-Coulter)). Una vez finalizada, se extraen fracciones de $1.5 \mathrm{ml}$ (en nuestros experimentos una media de 20) con una bomba peristáltica Peristaltic Pump P-3 (Pharmacia Fine Chemicals) y se guardan a $-80^{\circ} \mathrm{C}$. De estas fracciones se separan una parte para analizar los RNAs y las proteínas, y así identificar las fracciones en las que sedimentan 20S RNA y p91. 
a) RNA: Se utilizan $30 \mu \mathrm{l}$ de la fracción. Se añaden $70 \mu \mathrm{l}$ de agua milli-Q estéril y se procesa la muestra con fenol y fenol:cloroformo. Después de precipitar los ácidos nucleicos se lava, seca y resuspende en $10 \mu \mathrm{l}$ de agua milli-Q estéril y se analiza en un gel de agarosa.

b) Proteínas: Se separan $100 \mu \mathrm{l}$ de la fracción, se añaden $10 \mu \mathrm{l}$ de TCA 100\%, y después de 15 minutos en hielo la muestra se centrifuga durante 5 minutos a 4 으. El precipitado se lava con TCA $0.2 \%$ en una centrifugación a temperatura ambiente durante 5 minutos y se resuspende en $25 \mu \mathrm{l}$ de tampón de carga para proteínas. Se utilizan dos geles de acrilamida al 10\%, cada uno para analizar $10 \mu \mathrm{l}$ de las proteínas de la muestra, uno de ellos para teñir con plata, y el otro para detectar p91 con anticuerpos específicos mediante western.

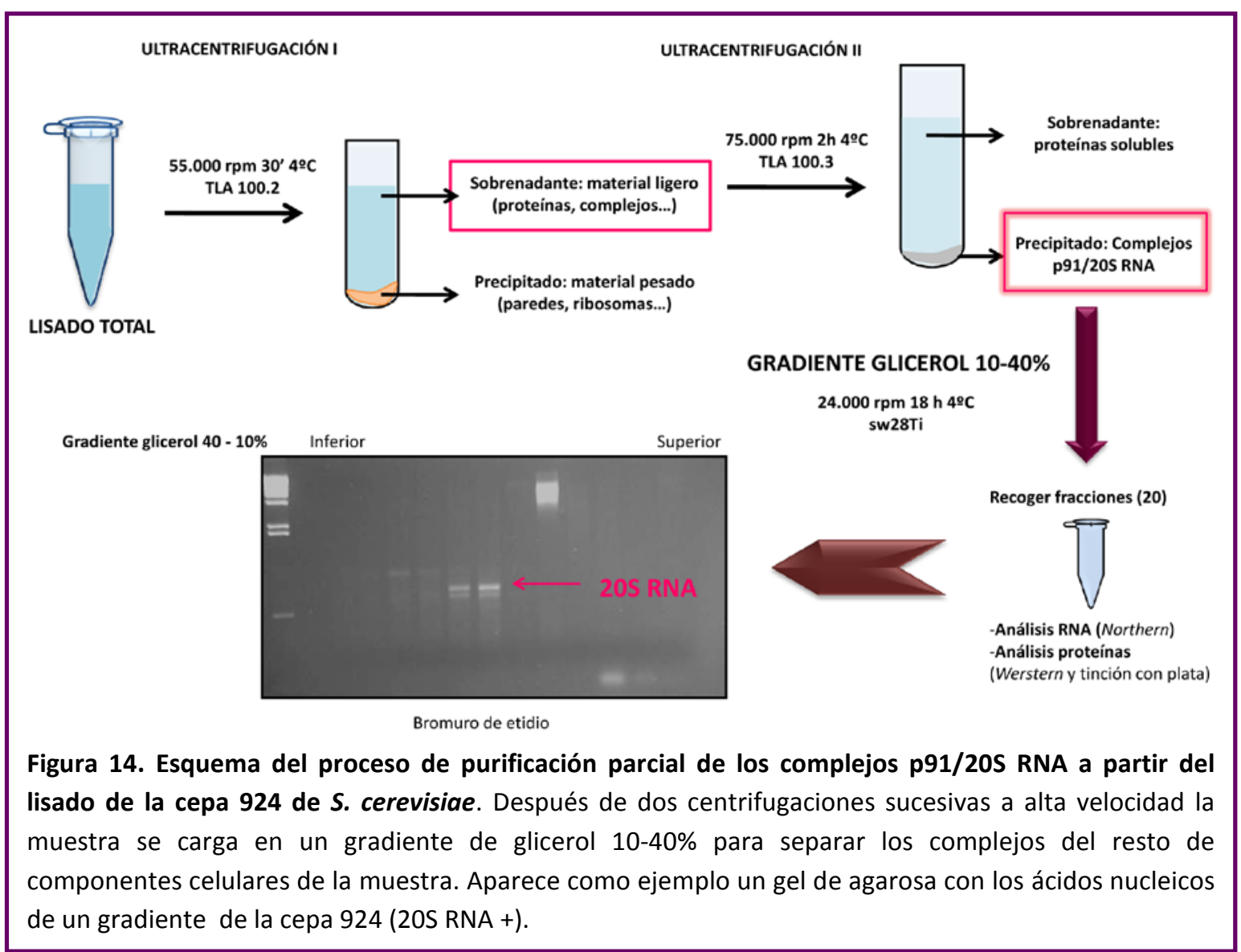

\subsection{INMUNOPRECIPITACIÓN}

La inmunoprecipitación consiste en la precipitación selectiva de proteínas utilizando anticuerpos específicos contra ellas. Las inmunoglobulinas $\mathrm{G}$ del anticuerpo se unen posteriormente a la proteína A de Staphylococcus aureus acomplejada con la sefarosa CL-4B (Amersham/GE- 
Healthcare ${ }^{\circledR}$ ), la cual sedimenta fácilmente precipitando a baja velocidad. Esta técnica se ha empleado tanto para detectar complejos p91/20S RNA (S. cerevisiae y E. coli) como posibles proteínas asociadas a ellos (S. cerevisiae). El procedimiento seguido se recoge en (Esteban et al., 1994) pero se resume a continuación:

La cantidad de lisado utilizado en las inmunoprecipitaciones depende del experimento, pero varía entre 10 y $150 \mu \mathrm{l}$ en S. cerevisie y 40 - $160 \mu \mathrm{l}$ en E. coli, que corresponden aproximadamente a 10 - $150 \mu \mathrm{g}$ de proteínas totales. El lisado se incuba en $1 \mathrm{ml}$ de tampón TBST con solución $20 \mathrm{ng}$ tRNA, 1 unidad $R N A \sin ^{\circledR}$ (Promega) y $2 \mu$ lantisuero anti-p91 durante 30 minutos a 4 ํC en agitación. A continuación se añaden $100 \mathrm{mg} / \mathrm{ml}$ de Proteína A sefarosa hidratada en TBST y se incuba de nuevo 30 minutos a 4 으 en agitación. Una vez terminado este proceso, la muestra se trata de manera distinta según las moléculas que queramos analizar. Para obtener resultados más limpios en algunas inmunoprecipitaciones cuyo resultado se iba a analizar en geles de acrilamida teñidos con plata, se utilzó como anticuerpo $0.5 \mu \mathrm{l}$ de la inmonuglobulina $\mathrm{G}$ purificada a partir del antisuero anti-p91 mediante cromatografía de afinidad con proteína A sefarosa.

\section{DETECCIÓN DE 20S RNA}

El RNA presente en el inmunoprecipitado se solubiliza con una solución de SDS 0.3\%, 5 mM EDTA. A continuación se realiza una extracción con fenol y dos con fenol:cloroformo, para desnaturalizar las proteínas. El RNA se precipita con etanol y se lava, se seca y finalmente se disuelve en $2 \mu \mathrm{l}$ de agua milli-Q. Posteriormente se desnaturaliza en presencia de Glioxal 1 M, DMSO (Dimetilsulfóxido) $0.6 \mathrm{M}$ y tampón sodio fosfato $\mathrm{pH} 6.6\left(\mathrm{NaH}_{2} \mathrm{PO}_{4}\right) 10 \mathrm{Mm}$ durante 30 minutos a $50^{\circ} \mathrm{C}$. Se añade $10 \times$ SSC a las muestras y se filtran al vacío sobre una membrana de nylon (Nytran ${ }^{\circledR}$ de Whatman $^{T M}$ ) en un Bio-Dot ${ }^{\circledR}$ Microfiltration System (Bio-Rad ${ }^{\circledR}$, a partir de ahora denominado Dot Blot). 20S RNA se detecta en la membrana mediante la hibridación con una sonda específica como se describe en el apartado 3.10 .

\section{PROTEÍNAS}

Para detectar las proteínas presentes en los complejos p91/20S RNA, los inmunoprecipitados se separan en geles de acrilamida seguidos de Western con anticuerpos específicos, tinción con plata o exposición directa del gel en el caso del marcaje in vivo con ${ }^{35} \mathrm{~S}$ (apartado 3.17). Se han empleado dos técnicas diferentes, utilizando distintos anticuerpos para detectarlas: 


\section{Anti-p91}

$50 \mu \mathrm{l}$ de las fracciones del gradiente enriquecidas con los complejos p91/20S RNA se incuban con IgG anti-p91 purificada y TBST durante una hora a 4ํㅡ en agitación. A continuación se añaden 50 $\mathrm{mg} / \mathrm{ml}$ de proteína A sefarosa y se incuba de nuevo. Después de lavar el inmunprecipitado las proteínas coinmunoprecipitadas se separan de la proteína A al añadir tampón de carga. Después de centrifugar un minuto las proteínas del sobrenadante se analizan en geles de SDS-PAGE.

\subsection{ENRIQUECIMIENTO DE COMPLEJOS CON ANTICUERPOS Anti-GFP CONJUGADOS}

Dado que los complejos p91-GFP/20S RNA se pueden inmunoprecipitar con aunticuerpos anti-GFP (Solórzano et al., 2000), utilizamos el protocolo comercial de Milteny Biotech ${ }^{\circledR}$ que consiste en emplear anticuerpos anti-GFP magnetizados de tal manera que al eluir con un tampón apropiado, y bajo el efecto de un campo magnético, todo aquello unido al anticuerpo (proteínas marcadas con GFP y las asociadas a ellas) queda retenido en una columna que posteriormente se eluirá con tampón de carga para proteínas y será analizado en un gel de acrilamida teñido con plata.

En esta técnica usamos las cepas 924 y 913 transformadas con el plásmido pALI53 que tiene clonada la proteína verde fluorescente (GFP), o con el plásmido pALI40 que expresa la proteína de fusión p91-GFP.

\subsection{MARCAJE in vivo CON ${ }^{35} \mathrm{~S}$}

Para marcar radiactivamente los grupos sulfato de los aminoácidos presentes en las proteínas de las cepas 924 y 913 de $S$. cerevisiae se añaden $0.36 \mathrm{mCi} / \mathrm{ml}$ de una mezcla de metionina y cisteína marcadas con ${ }^{35} \mathrm{~S}\left(11 \mathrm{mCi} / \mathrm{ml}\right.$ Perkin Elmer $\left.{ }^{\oplus}\right)$ a $5 \mathrm{ml}$ de medio $\mathrm{H}$-Cys + Met $(20 \mu \mathrm{g} / \mathrm{ml})$. Las células crecen a $28^{\circ} \mathrm{C}$ durante 72 horas y después de recoger y lavarlas se transfirieren a $10 \mathrm{ml}$ de KAc 1\% pH 7.0 para favorecer la inducción de 20S RNA. Una vez recogidas las células por centrifugación se rompen de la manera estándar con la Fast-Prep. El lisado se somete a dos centrifugaciones diferenciales, descritas en el apartado 3.13 y el precipitado de la última centrifugación se resuspende en $150 \mu$ l de tampón de lisis.

A continuación se inmunoprecipitan $50 \mu$ le las muestras utilizando $0.5 \mu \mathrm{l}$ de inmonuglobulina $\mathrm{G}$ anti-p91 purificada, 20 ng de tRNA y $300 \mu \mathrm{l}$ de tampón TBST. Se siguen las condiciones descritas en el apartado 3.15 para inmunoprecipitar los complejos p91/20S RNA.

Las proteínas del inmunoprecipitado se analizaron mediante SDS-PAGE. A continuación se fijan al gel con una solución Metanol 50\% Ac. Acético 10\% y finalmente el gel se sumerge en la 
solución Amplify $^{T M}$ (Amersham/GE-Healthcare ${ }^{\circledR}$ ) para incrementar la señal al exponer el gel una vez seco en un casete con una película de autorradiografía.

\subsection{EXPRESIÓN DE RNA Y PROTEÍNAS EN E. coli}

La expresión de proteínas en E. coli se realizó en la cepa BL21(DE3). Para ello se transformaron las células con el plásmido pLOR91 (o derivados). 4 - 5 transformantes se inoculan en $10 \mathrm{ml}$ de medio LB suplementado con kanamicina $50 \mu \mathrm{g} / \mathrm{ml}$ y se incuban a $37^{\circ} \mathrm{C}$ durante 3 horas, tiempo en el que el cultivo alcanza su fase logarítmica. A continuación se induce la expresión de T7 mediante la adición de IPTG (Isopropil- $\beta$-D-tiogalactopiranósido) $10 \mathrm{mM}$. Durante las 5 horas a 28으 que mantuvimos las células la T7 transcribe grandes cantidades del DNA clonado bajo su promotor. Las células recogidas por centrifugación se guardan a -80 으, para posteriormente analizar la expresión de $20 \mathrm{~S}$ RNA y p91 y la formación de complejos ribonucleoproteicos entre ambas moléculas.

\section{VECTORES Y PLÁSMIDOS EMPLEADOS}

A continuación se resumen algunos de los vectores empleados en la elaboración de este trabajo. En la Tabla 3 del Anexo I se encuentra una descripción detallada de todos los plásmidos contruidos y utilizados en esta memoria, aunque en la Tabla 6 de esta sección hay una lista de los más representativos.

\subsection{VECTORES DE E. coli}

pBluescript KS+ (Stratagene)

Este vector es un plásmido autorreplicativo de $2.9 \mathrm{~kb}$ que lleva el gen de resistencia a ampicilina, el origen de replicación colE1 y un fragmento del operón de lactosa de $E$. coli que codifica el péptido $\alpha$ de la $\beta$-galactosidasa (LacZ'). Este plásmido tiene el sitio de clonación múltiple (polilinker) KpnI-Sacl, entre los promotores de las RNA polimerasas T7 y T3 que lo flanquea, lo que le hace adecuado para la síntesis de RNA in vitro. Contiene también el origen de replicación del fago f1 para poder hacer mutaciones dirigidas in vitro. 
pLM62+

Este vector procede del pT7-7 (Tabor y Richardson, 1985). Contiene el promotor $\phi 10$ de la T7 RNA polimerasa, un sitio de clonación múltiple con ocho sitios de restricción y el gen de resistencia a ampicilina. pLM62+ contiene además el origen de replicación del fago f1 (Esteban, 1993).

\subsection{VECTORES DE S. cerevisiae}

pl2

El plásmido pl2 (Wickner et al., 1991) procede de p375 (derivado de YEpIPT con sitio de clonación múltiple) (Hitzeman et al., 1983) al que se le insertó el origen de replicación del fago f1 para poder obtener DNA monocatenario.

p375

El vector de expresión en levaduras p375 contiene los siguientes elementos:

a) Fragmento de $1.6 \mathrm{~kb}$ prodecente del cromosoma III de S. cerevisiae en la región anterior al gen PGK1. Contiene las secuencias promotoras de este gen, lo que hace que los genes y proteínas clonadas detrás se expresen constitutivamente. Detrás del promotor PGK1 existe un sitio de clonación múltiple. Entre el inicio de la transcripción y el polilinker hay 47 nt.

b) Fragmento de $2 \mathrm{~kb}$ procedente del plásmido de $2 \mu$ (forma $\mathrm{B}$ ). contiene el origen de replicación para el mantenimiento en la levadura y las señales de terminación de la transcripción y poliadenilación adecuadas para la expresión de los genes clonados detrás del promotor PGK1.

c) $\quad 0.8 \mathrm{~kb}$ del cromosoma de levaduras que contiene el gen TRP1.

d) Fragmento de pBR322 que contiene el gen de resistencia a Ampicilina, el origen de replicación para $E$. coli y parte del gen de resistencia a tetraciclina.

pALI23

Es el vector de expresión en levaduras con marcador URA3. Se construyó sobre pl2, insertando un fragmento de $1.1 \mathrm{~kb}$ procedente del plásmido yEP24 que contiene el gen URA3 de $S$. cerevisiae. Este gen está clonado dentro del gen TRP1. 
pRS313

Vector centromérico de $S$. cerevisiae. Contiene el origen de replicación del fago f1, los promotores de T7 y T3, el gen de resistencia a ampicilina y el casete CEN6/ARSH4 que Ileva la secuencia del centrómero del cromosoma VI de S. cerevisiae (CEN6) y la secuencia autorreplicativa $A R S$ asociada a la histona 4 (ARSH4). Lo que lo diferencia de otros plásmidos parecidos (serie pRS) es que tiene un fragmento de 1.18 kb que contiene el gen HIS3 (Sikorski y Hieter, 1989). Los genes clonados en este plásmido (y sus derivados) deben ir acompañadas de su promotor.

Utilizando los vectores anteriores y sus derivados se han construido los plásmidos necesarios para la elaboración de este trabajo. Estos están recogidos en la TABLA 6. En la figura 15 se muestra el esquema de dos de los más importantes pRE740 y pLOR91, derivados de pl2 y pLM62+ respectivamente.

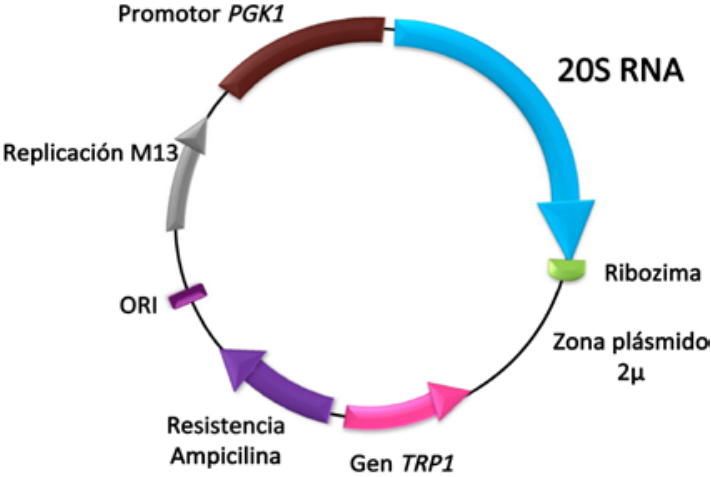

pRE740

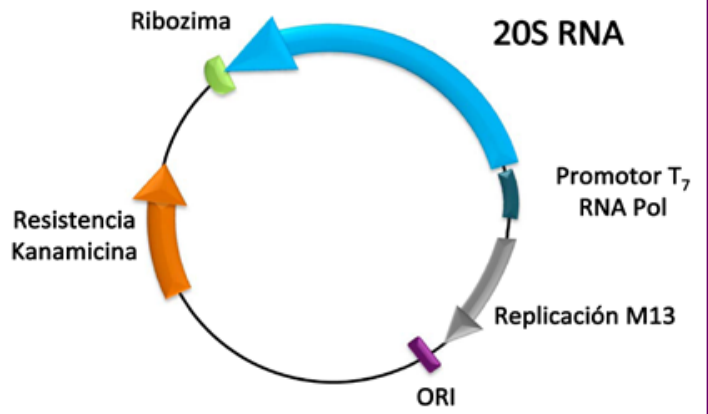

pLOR91

Figura 15. Esquema de los plásmidos pRE740 y pLOR91, utilizados en este trabajo para la expresión estándar de $20 S$ RNA y p91 en S. cerevisiae y E. coli respectivamente

TABLA 6: Plásmidos más importantes utilizados en el trabajo

\begin{tabular}{l|l}
\hline Nombre & Características \\
\hline \multicolumn{2}{c}{ Saccharomyces cerevisiae } \\
\hline pRE740 & Genera el virus 20S RNA. Marcador TRP1. \\
pRE763 & Genera el virus 20S RNA. Marcador URA3. \\
pRE787 & C4A en el extremo 3' de la cadena (+) de 20S RNA (...GCACC-OH). \\
pRE805 & Genera la cadena (-) de 20S RNA. Tiene un sitio interno Smal.
\end{tabular}




\begin{tabular}{|c|c|}
\hline pRE908 & $\begin{array}{l}\text { Expresa el gen } X R N 1 \text { a partir de su propio promotor en un plásmido centromérico (pRS313) de } S \text {. } \\
\text { cerevisiae. }\end{array}$ \\
\hline pRE914 & $\begin{array}{l}\text { ORF del gen XRN1 amplificada con los oligos RE296 y RE297 a partir de DNA de la cepa 2928-4 y } \\
\text { clonada en el plásmido pl2 de S. cerevisiae para sobreexpresar la proteína Xrn1p. }\end{array}$ \\
\hline pRE921 & pRE908 que tiene modificado el motivo exonucleasa de $\operatorname{Xrn1p}$ clonada en este plasmido. \\
\hline pLOR7 & Se modifican las primeras bases de la ribozima, GGG pasan a AAA en el plásmido pRE740. \\
\hline \multicolumn{2}{|c|}{ Escherichia coli } \\
\hline pLM62+ & $\begin{array}{l}\text { pT7-7 con el origen de replicación del fago M13. Tiene la secuencia de Shine-Dalgarno para la } \\
\text { expresión de proteínas en E. coli. }\end{array}$ \\
\hline pALI17 & $\begin{array}{l}\text { pBluescript KS+ con la secuencia de } 20 \text { S RNA completa fusionada al promotor de T7. Sirve para } \\
\text { sintetizar in vitro la cadena }(+) \text { de } 20 \text { S RNA. }\end{array}$ \\
\hline pRE449 & $\begin{array}{l}\text { pBluescript KS+ con la secuencia de } 20 \text { SNA desde la base 1253-2514. Sirve para hacer sonda de } \\
\text { 20S RNA. }\end{array}$ \\
\hline pLOR91 & Plásmido derivado de pLM62+ que expresa 20S RNA y p91 bajo el promotor de la T7. \\
\hline pLOR92 & $\begin{array}{l}\text { pBluescript KS+ con la secuencia de } 20 \mathrm{~S} \text { RNA (pALI17) con ribozima. Para experimentos de } \\
\text { expresión de } 20 \mathrm{~S} \text { RNA en E. coli. }\end{array}$ \\
\hline pLOR116 & Se introduce un codón de parada después del aminoácido Leu274 de p91 en pLOR91. \\
\hline
\end{tabular}

\section{MÉTODOS GENÉTICOS}

La conjugación entre dos cepas con fenotipo sexual opuesto, la selección de diploides, esporulación y posterior análisis de las esporas mediante disección de tétradas se llevó a cabo siguiendo los métodos de Genética clásica de Mortimer (Mortimer y Hawthorne, 1975).

\subsection{AISLAMIENTO DE ASCOSPORAS MEDIANTE MICROMANIPULACIÓN: ANÁLISIS DE TÉTRADAS}

La micromanipulación de ascosporas permite separar las cuatro esporas de una célula diploide que se producen tras la esporulación de la misma.

El cultivo con los diploides de S. cerevisiae tiene que estar en fase logarítmica en el momento que se induce la esporulación mediante acetato de potasio al $1 \%$. Después de 24 a 48 horas en este medio a $25^{\circ} \mathrm{C}$ se observan las células al microscopio para comprobar si la esporulación ha tenido lugar. En caso afirmativo, se recogen las células, se añaden 10.000 unidades de Glusulasa ${ }^{\circledR}$ (Pelkin Elmer $^{\oplus}$ ) y se incuba la muestra 10 minutos a $37^{\circ} \mathrm{C}$, tiempo durante el cual se rompe la pared 
del asca. La muestra se micromanipula en placa en un micromanipulador Singer Instruments MSM Systems, separando las cuatro esporas. La placa se incuba a $28^{\circ} \mathrm{C}$, y posteriormente se analiza mediante réplicas en placas con diferentes auxotrofías los marcadores de cada espora.

\subsection{CITODUCCIÓN}

El proceso de citoducción consiste en la transmisión de elementos extracromosomales desde una cepa haploide hasta otra de tipo sexual opuesto, sin que haya cambios en la dotación genética nuclear. Durante este proceso, en el que hay mezcla de citoplasmas al fusionarse las cepas parentales, no se producen células diploides debido a que una de las estirpes presenta la mutación kar1-1 y es defectiva en fusión nuclear (Conde y Fink, 1976). Se forman, por tanto, heterocariontes transitorios que en la primera división mitótica forman de nuevo dos células haploides con núcleos idénticos a los parentales y con los citoplasmas mezclados.

Dado que la presencia de 20S RNA no confiere nungún fenotipo a la célula portadora, la única forma de conocer si alguna célula receptora ha adquirido el virus por citoducción es de manera indirecta, comprobando la adquisición de otros elementos existentes en el citoplasma y cuya presencia sí pueda ser detectada, como por ejemplo las mitocondrias.

Las cepas dondadoras han de ser $\left[\mathrm{rho}^{+}\right]\left(\rho^{+}\right)$y las receptoras [rho-] $\left(\rho^{-}\right)$. Las cepas $\rho^{-}$se pueden obtener por crecimiento en placas de YPAD suplementadas con bromuro de etidio. Las colonias citoducidas que se transformarán en $\rho^{+}$se podrán distinguir de las $\rho^{-}$mediante la utilización de fuentes de carbono no fermentables, como es el caso del medio YPG, que lleva glicerol en vez de glucosa como fuente de carbono.

Ambas cepas parentales (donadora y receptora) conjugan en medio YPAD durante 7-8 horas a 28ㄷ․ Después de este tiempo podemos obtener cuatro tipos de células diferentes en las placas: las dos cepas parentales originales haploides que no han conjugado, un número pequeño de células diploides que han sido capaces de fusionar sus núcleos a pesar de la mutación kar1-1 y las células citoducidas. Mediante el aislamiento de colonias en medios carentes de alguno de los marcadores auxotróficos de las cepas parentales y réplicas en medio YPG (para distinguir la cepa receptora $\rho^{-}$de la citoducida $\rho^{+}$). 


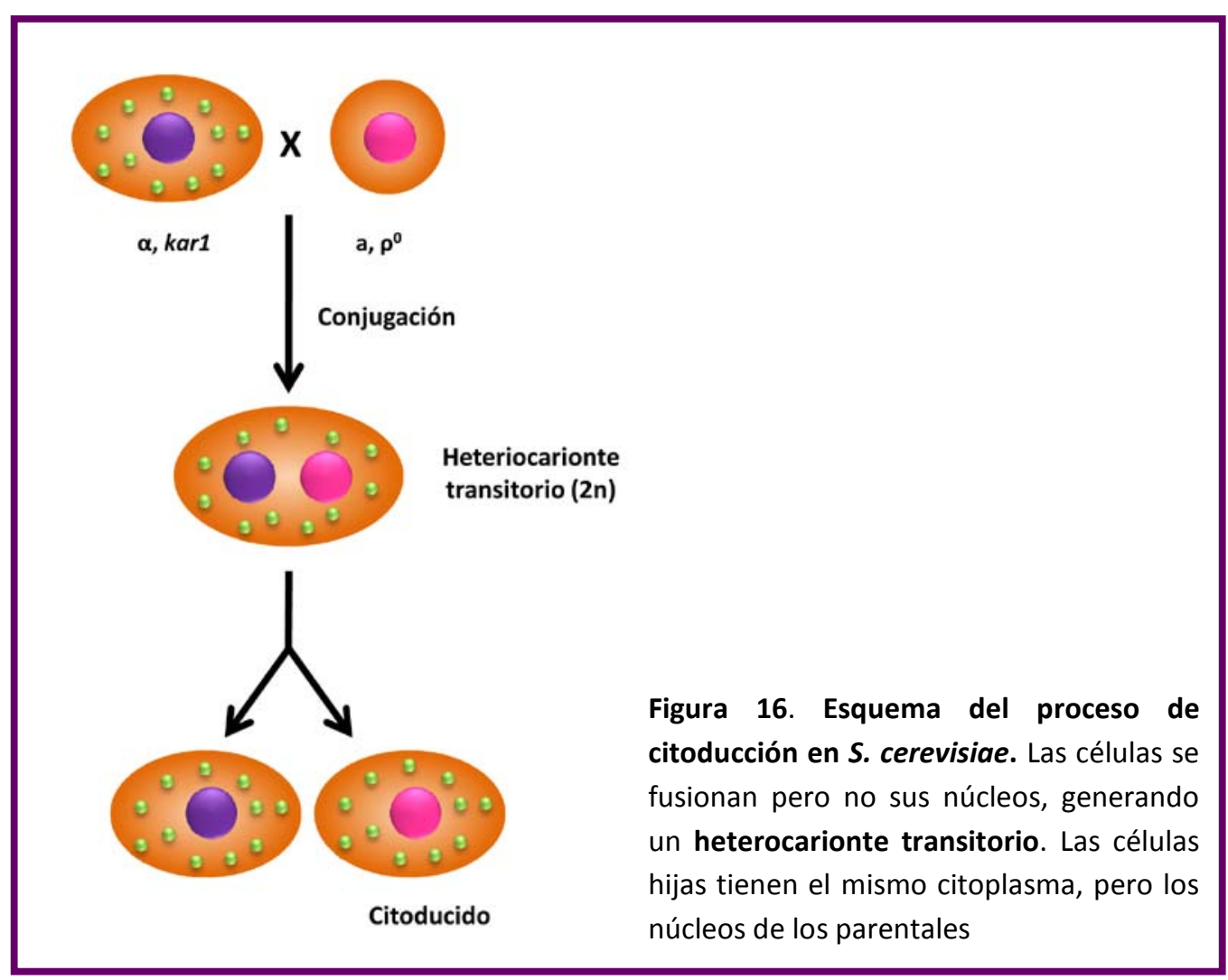

\section{ANÁLISIS BIOINFORMÁTICO DE DATOS}

Para el análisis bioinformático de las secuencias de DNA y de aminoácidos se utilizaron los programas DNASTAR ${ }^{\text {TM }}$ y 4 Peaks.

El diseño de plásmidos y oligonucleótidos se realizó con el programa Gene Construction Kit.

El anillamiento de secuencias se hizo con el programa ClustalX.

Las secuencias génicas y proteicas de $S$. cerevisiae se obtuvieron de la base de datos Saccharomyces Genome Database (SGD) (www.yeastgenome.org).

Las relaciones filogenéticas de las RdRp se establecieron mediante el programa Mega2.

Las búsquedas bibliográficas se realizaron principalmente a través de las bases de MEDLINE ${ }^{T M}$.

El análisis de las estructuras secundarias de las moléculas de RNA se realizó mediante el programa MFOLD (Zuker, 2003). 
RESULTADOS

"El genio es un uno por ciento de inspiración y un noventa y nueve por ciento de sudor"

THOMAS A. EDISON 


\section{GENERACIÓN DE 20S RNA EN S. cerevisiae A PARTIR DE UN VECTOR DE EXPRESIÓN}

Tal y como se describió en la Introducción, es posible generar 23S RNA en levaduras a partir de un vector de expresión. Para estudiar de forma similar la posible generación de 20S RNA a partir de plásmidos, se siguió el procedimiento que se describe a continuación:

La cepa 2928-4 de S. cerevisiae, que carece del virus, se transformó con el plásmido pRE740. Este plásmido se construyó clonando el cDNA completo de 20S RNA en el vector de expresión de levaduras pl2, bajo el promotor constitutivo PGK1. Para obtener transcritos con el extremo 3' idéntico al de 20S RNA se fusionaron 82 nt de la cadena antigenómica de la ribozima del virus delta de la Hepatitis (HDV) detrás de la secuencia del virus (Perrotta y Been, 1991). El plásmido contiene además el gen TRP1 como marcador seleccionable (Fig. 16-A). Cuando se visualiza el RNA obtenido de los transformantes en un gel de agarosa teñido con bromuro de etidio se observa que en la cepa transformada aparece una banda entre los RNAs ribosomales (rRNA) de la levadura, cuya movilidad se corresponde con el RNA viral de una cepa con el virus endógeno (cepa 2928) (Fig. 16-B). Para comprobar que se trata del genoma de 20S RNA, los RNAs se transfirieron a una membranas de nylon que se hibridaron con sondas específicas de la cadena (+) y la cadena (-). El dato del Northern sugiere que existe replicación del transcrito primario procedente de pRE740, ya que se detectan las cadenas de polaridad (-). Esto indica que el RNA se ha traducido para dar lugar a p91 y ésta lo ha replicado in vivo. Además el virus así originado es autónomo y no depende del plásmido, ya que una vez eliminado 20S RNA se mantiene en la célula en una cantidad similar a la del virus endógeno.

Aunque los transcritos generados a partir de pRE740 (o plásmidos derivados) tienen el extremo 3' idéntico al del virus endógeno, en 5' hay 47 nt que proceden del vector. Mediante experimentos de primer extension se ha comprobado que esa secuencia no viral desaparece en los virus generados.

Este sistema, al igual que en el caso de 23S RNA, permite realizar estudios de genética reversa, modificando la secuencia del genoma viral in vitro para ver el efecto del cambio introducido sobre la generación del virus in vivo. 


\section{A}

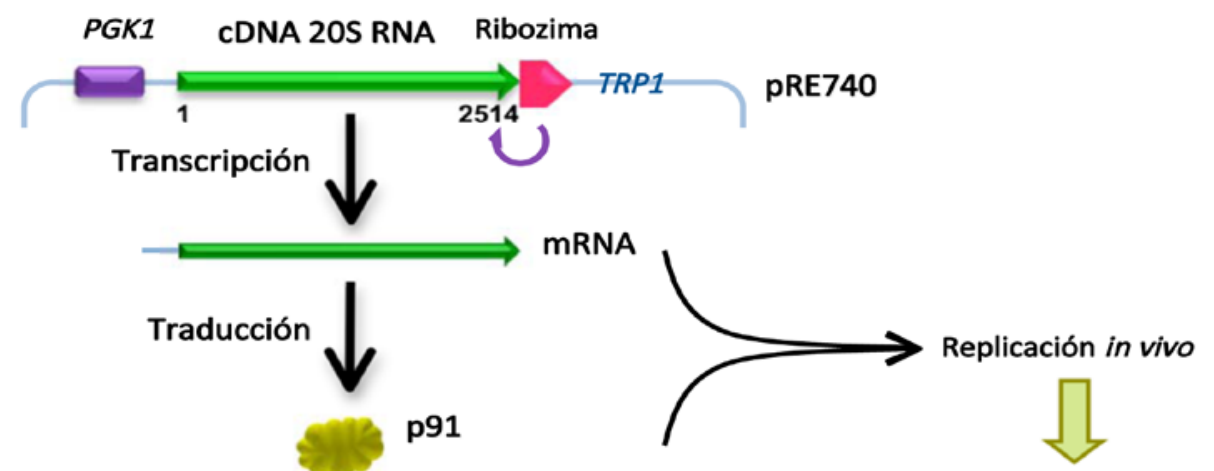

\section{GENERACIÓN 20S RNA}

B

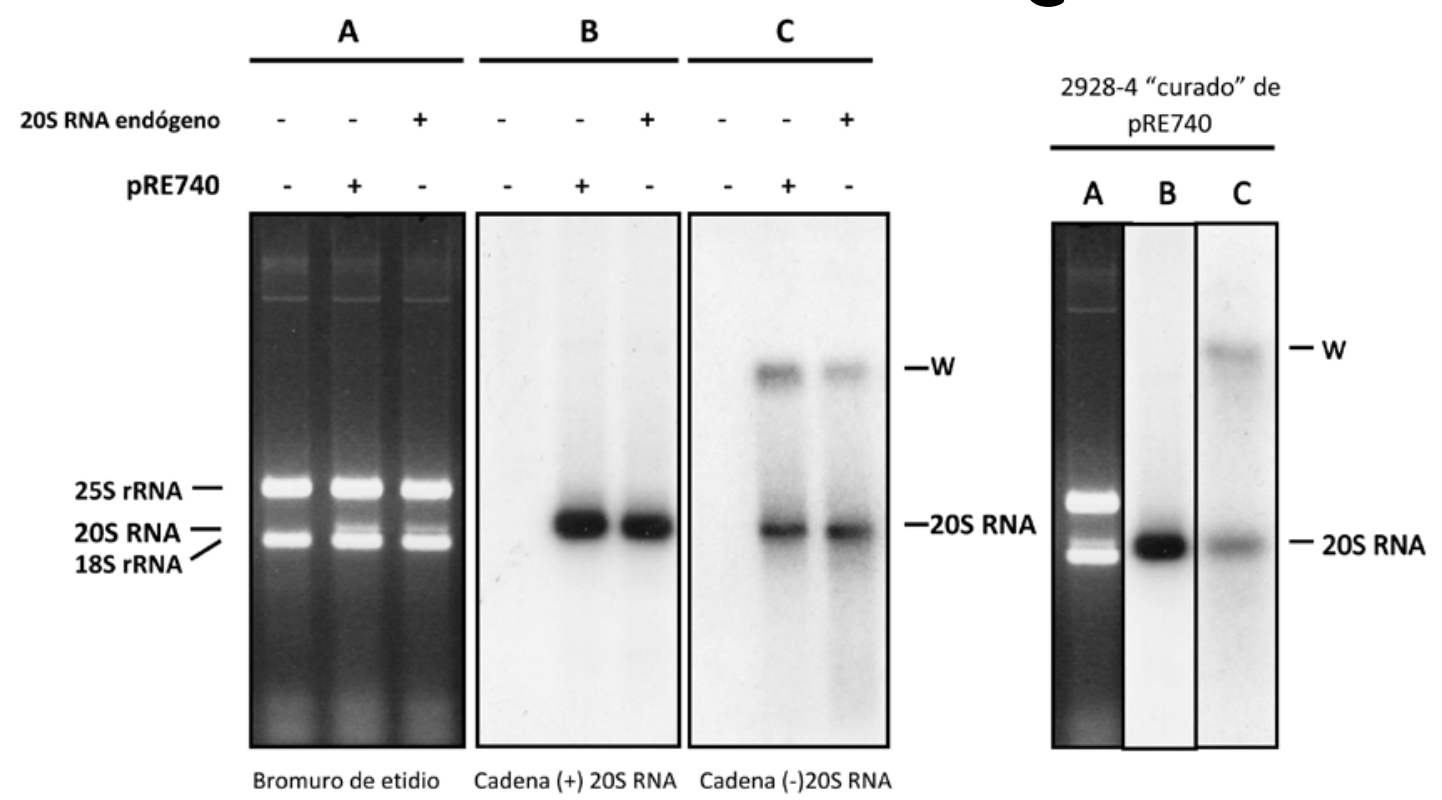

Figura 16. Generación de 20S RNA en S. cerevisiae. A.Diagrama del plásmido pRE740 utilizado para la generación de $20 \mathrm{~S}$ RNA. Los productos de expresión son el transcrito y la RNA polimerasa p91, que lo replica para dar lugar al virus. B. Generación del virus S. cerevisiae. La cepa 2928-4 (sin virus endógeno) se transforma con el plásmido pRE740 y el RNA de las células se analiza en un gel de agarosa teñido con bromuro de etidio (A). Las cadenas $(+)$ y $(-)$ del RNA viral se detectan mediante Northern con sondas específicas (B) y (C). La cantidad de virus generado a partir de pRE740 es similar al de la cepa 2928 (virus endógeno). Se indica la posición de 20S RNA y la forma bicatenaria W en los Northern. W se visualiza mejor cuando se detectan las cadenas (-), ya que la membrana está sobreexpuesta. C. El virus generado no depende de pRE740 para su mantenimiento. 20S RNA es estable en la célula una vez eliminado el plásmido del que procede (cepa "curada").

En los experimentos de Northern con plásmidos derivados de pRE740, que se muestran en los apartados siguientes, se ha utilizado solamente la detección de las cadenas (+) en vez de sondas de las dos polaridades. En todos los casos analizamos al menos dos transformantes, pero en las figuras sólo se muestra el resultado de uno para simplificar los datos. 


\section{ESTUDIO DE LAS SEÑALES EN cis EN EL EXTREMO 3' QUE AFECTAN A LA REPLICACIÓN Y FORMACIÓN DE COMPLEJOS p91/20S RNA}

La secuencia de los extremos 5' y $3^{\prime}$ de 20 S RNA tiene cinco nucleótidos invertidos y repetidos, que además son comunes al virus 23S RNA (5'-GGGGC...GCCCC-OH 3'). Uno de los objetivos de este trabajo es determinar las posibles señales en cis presentes en el extremo 3' de $20 \mathrm{~S}$ RNA, ya que resultados previos con el otro narnavirus indican la importancia de este extremo en su replicación y en la formación de los complejos entre el RNA y la polimerasa.

\subsection{ESTUDIOS DE REPLICACIÓN DE LA CADENA (+)}

\subsubsection{MODIFICACIÓN DE LAS CUATRO ÚLTIMAS BASES}

El sistema de generación del virus anteriormente descrito permite modificar la secuencia de 20S RNA in vitro sobre el plásmido de expresión pRE740 para posteriormente analizar su efecto sobre la generación de 20S RNA in vivo. En primer lugar examinamos el papel de los últimos cuatro nucleótidos de 20S RNA cambiándolos de citosinas a adeninas $(C \rightarrow A)$.

Como se observa en la figura 17 el cambio de la última o penúltima citosina no afecta a la generación de $20 \mathrm{~S}$ RNA, pero sí lo hacen los cambios en la tercera o cuarta (desde el extremo 3'). Por lo tanto, la tercera y la cuarta citosinas son esenciales para la replicación.

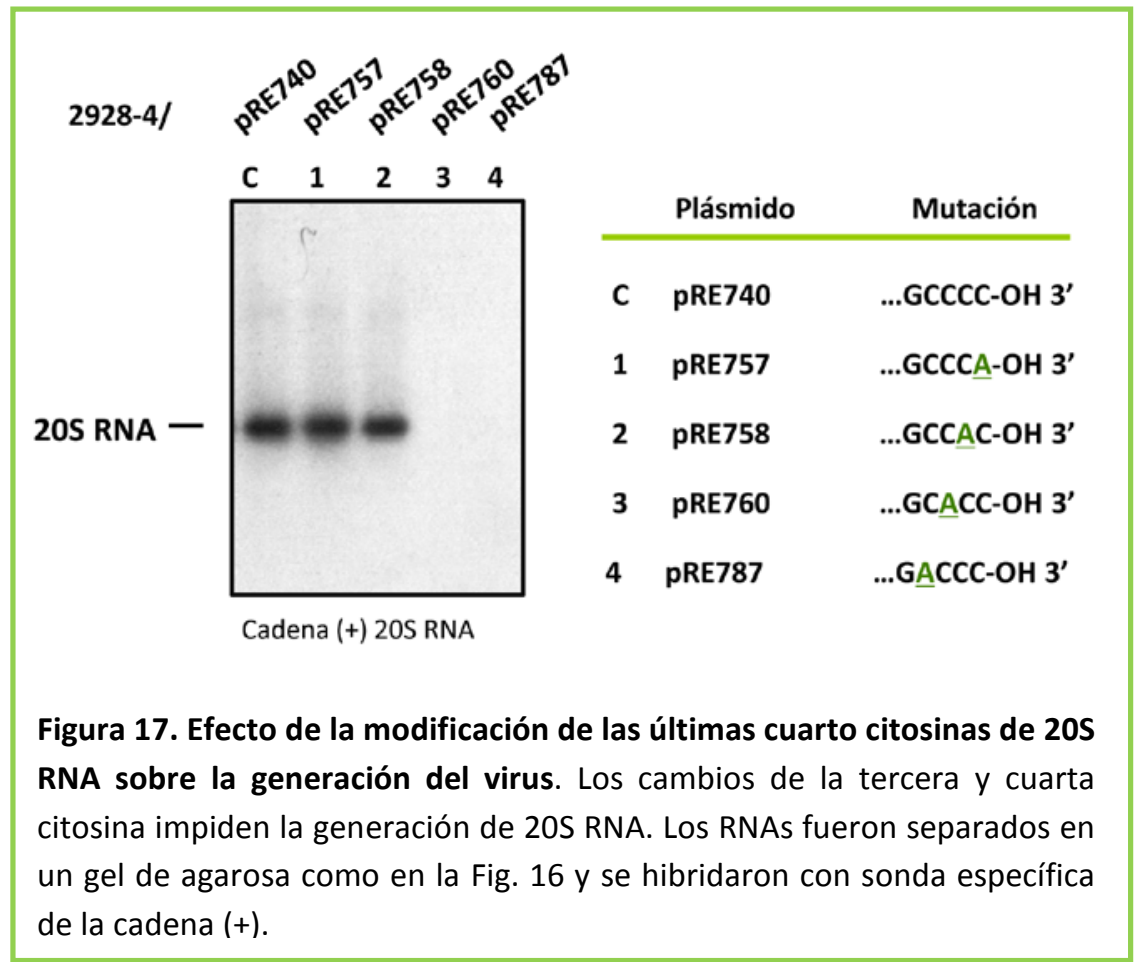




\subsubsection{EFECTO DE LA ADICIÓN O ELIMINACIÓN DE BASES EN EL EXTREMO 3’}

Para estudiar en más detalle la importancia de la secuencia en 3', se eliminaron la última o las dos últimas bases. Como se observa en la figura 18, la ausencia de estas citosinas tampoco afecta a la replicación de 20S RNA, lo que indica que no son necesarias.

En otros experimentos, en vez de disminuir la secuencia en 3', se añadieron una o tres bases en dicho extremo, delante de la secuencia de la ribozima, para comprobar si la presencia de secuencias extra afectaba a la generación del virus. En la figura 18 se observa que la adición de estos nucleótidos en el extremo 3' no afecta a la generación de 20S RNA, aunque existe mayor dificultad en el caso de que la base extra sea guanina (G), tanto una como tres. Sin embargo, una vez que el virus se ha generado a partir de estos vectores con guaninas extra y el plásmido es eliminado de las células, la cantidad de virus presente en estas cepas es indistinguible respecto a los otros mutantes, o incluso al virus silvestre (no se muestra).

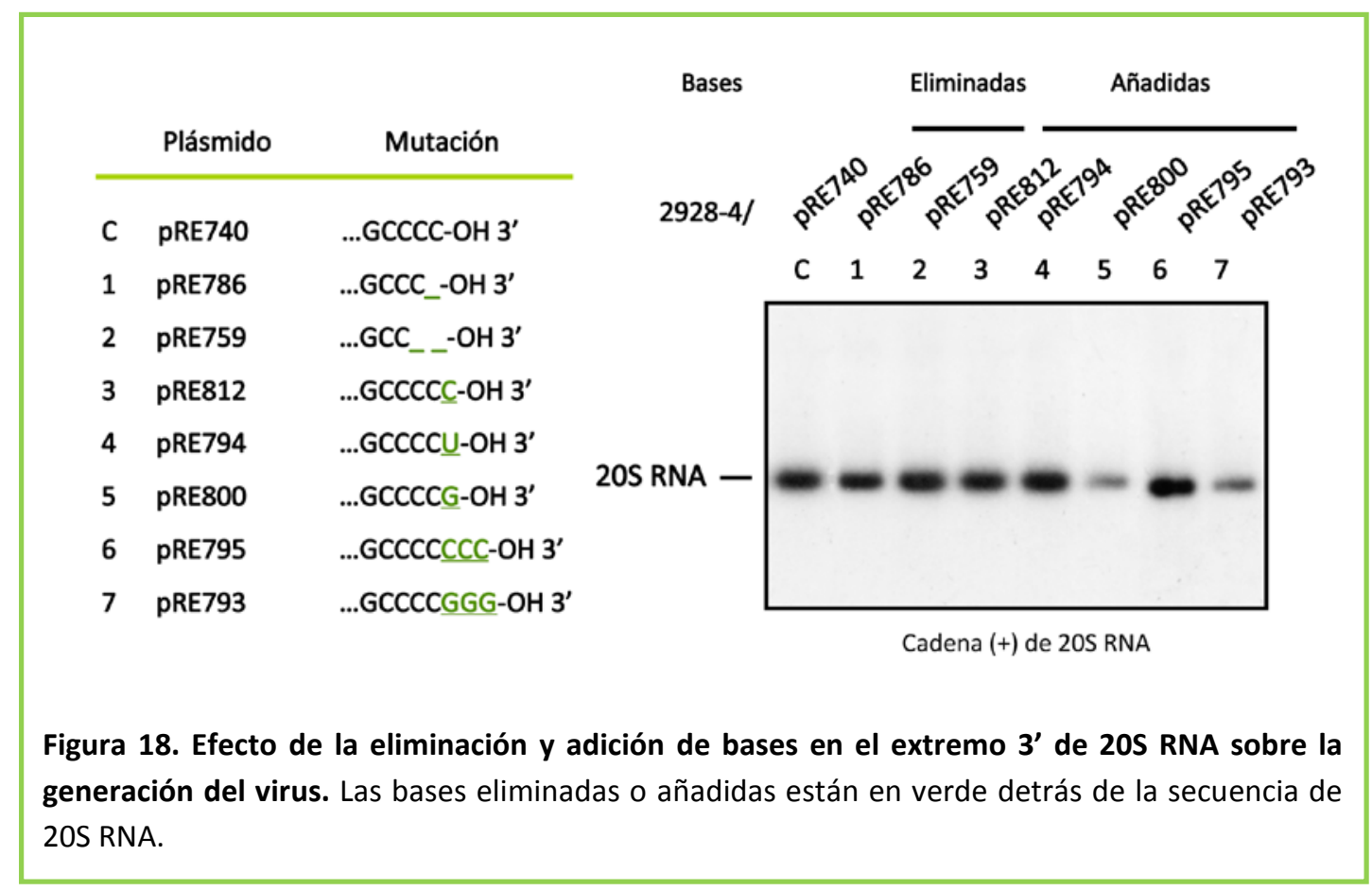

Para estudiar si las modificaciones introducidas se mantenían en los virus generados, secuenciamos sus extremos 3', habiendo eliminado previamente el plásmido de expresión. Para ello se amplificó el extremo 3' del genoma viral mediante 3'-RACE y se analizaron 8 - 10 clones independientes. Como se muestra en la Tabla 7, la sustitución de la última o penúltima $C$ por $A$, es corregida en los virus generados. Además, en el caso de la eliminación de las dos últimas Cs, éstas se recuperan. En la mayoría de los clones analizados recuperamos virus con la secuencia en $3^{\prime}$ del virus endógeno (4 Cs), nunca con el cambio introducido in vitro. Estos resultados indican que $20 \mathrm{~S}$ RNA tiene un eficiente mecanismo de reparación in vivo, capaz de restaurar el extermo 3' para que 
siempre haya cuatro citosinas. Además, en los casos en los que se habían añadido varias bases al extremo 3', éstas se han eliminado, indicando claramente que 20S RNA tiene un mecanismo para mantener el tamaño y la secuencia del extremo 3' de las cadenas (+). Esto es similar a lo que ocurre en 23S RNA (Fujimura y Esteban, 2004a).

\begin{tabular}{|c|c|c|}
\hline PLÁSMIDO & $\begin{array}{c}\text { CLONES } \\
\text { ANALIZADOS }\end{array}$ & SECUENCIA 3' \\
\hline pRE757 (...CCAC-OH) & 8 & $\begin{array}{l}7 \text {....CCCC-OH } \\
1 \text {...CCC_-OH }\end{array}$ \\
\hline pRE758 (...CCAC-OH) & 8 & $\begin{array}{l}7 \ldots \mathrm{CCCC}-\mathrm{OH} \\
1 \ldots \mathrm{CCCC}(\mathrm{G})-\mathrm{OH}\end{array}$ \\
\hline pRE759 (...CCC_-OH) & 8 & $\begin{array}{ll}7 & \ldots \mathrm{CCCC}-\mathrm{OH} \\
1 & \ldots \mathrm{CCCC}(\mathrm{G})-\mathrm{OH}\end{array}$ \\
\hline pRE794 (...CCCCU-OH) & 9 & $\begin{array}{ll}7 & \ldots \mathrm{CCCC}-\mathrm{OH} \\
1 & \ldots \mathrm{CCCC}(\mathrm{G})-\mathrm{OH} \\
1 & \ldots \mathrm{CCCC}(\mathrm{U})-\mathrm{OH}\end{array}$ \\
\hline pRE800 (...CCCCG-OH) & 10 & $\begin{array}{ll}7 & \ldots \mathrm{CCCC}-\mathrm{OH} \\
1 & \ldots \mathrm{CCCC}(\mathrm{C})-\mathrm{OH} \\
2 & \ldots \mathrm{CCC} \_-\mathrm{OH}\end{array}$ \\
\hline pRE795 (...CCCCCCC-OH) & 10 & $\begin{array}{ll}7 & \ldots . . \mathrm{CCCC}-\mathrm{OH} \\
3 & \ldots . . \mathrm{CCC}-\mathrm{OH}\end{array}$ \\
\hline pRE793 (...CCCCGGG-OH) & 10 & $\begin{array}{ll}8 & \ldots \mathrm{CCCC}-\mathrm{OH} \\
1 & \ldots \mathrm{CCCC}(\mathrm{G})-\mathrm{OH} \\
1 & \ldots \mathrm{CC}-_{-}-\mathrm{OH}\end{array}$ \\
\hline
\end{tabular}

El hecho de que las últimas cuatro citosinas se recuperen cuando introducimos un cambio, o añadimos otras bases, indica que son importantes para la replicación de 20S RNA, y por tanto, constituyen una señal en cis en esta parte del genoma.

\subsubsection{MODIFICACIÓN DE LA ESTRUCTURA SECUNDARIA}

\section{IMPORTANCIA DE LA QUINTA GUANINA}

Los 35 últimos nucleótidos del genoma de 20S RNA forman una estructura secundaria en horquilla, con un brazo de 13 nts y una burbuja de 5 (Fig. 19). 


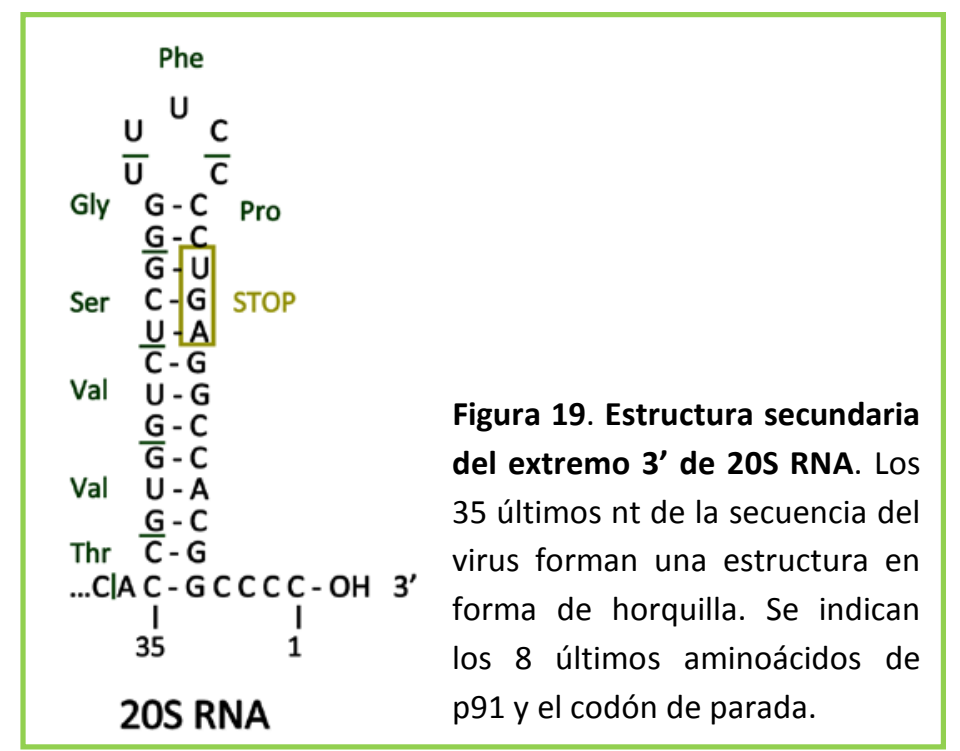

Cuando modificamos la quinta guanina por una citosina (G5C, pRE843) el virus no se genera (Fig. 20, carril 1). Para saber si la importancia de esa base en 20 S RNA reside en su secuencia per se, o en la estructura secundaria de la que forma parte, que con el cambio se abre dejando un brazo de 12 bp, realizamos la serie de modificaciones que se describen a continuación.

Primero, para restaurar la estructura manteniendo la modificación G5C, se introdujo la mutación compensatoria C35G (pRE848). Como esta variación produce además el cambio de aminoácido Thr823Ser, realizamos dos controles: un plásmido que contiene la mutación A36U, en la que se cambia el aminoácido Thr823Ser, pero que al estar fuera del brazo, no afecta a la estructura secundaria del RNA (pRE850), y como se observa en la figura 20 (carril 3), tampoco a la generación del virus, y otra con la mutación sencilla C35G, pero manteniendo la secuencia 3' original del virus (...GCCCC-OH) (pRE849). En este caso, el virus no se genera, lo que sugiere que la quinta base, sea guanina o citosina, necesita estar apareada formando parte de la estructura secundaria.

Para comprobar que el doble mutante (G5C, C35G) no revierte durante la generación del virus, se aisló RNA viral de la cepa una vez eliminado el plásmido, y se secuenció el extremo 3' mediante 3'-RACE. Se comprobó que todos los clones analizados (10) retenían ambas mutaciones, lo que indica que la quinta guanina no es importante para la generación de 205 RNA, lo es la estructura secundaria de la que forma parte. 


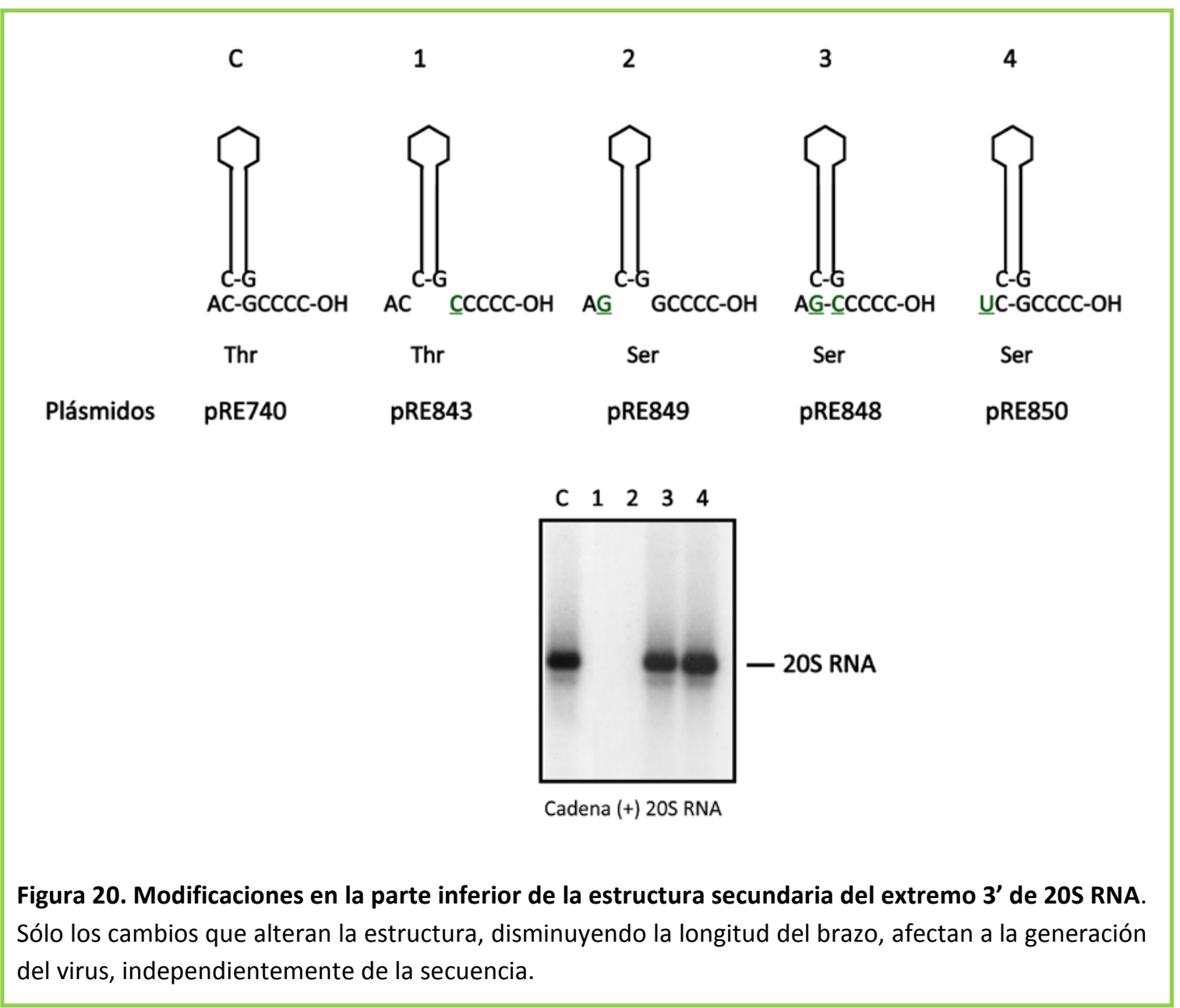

\section{OTRAS MODIFICACIONES EN EL EXTREMO 3' DE 20S RNA}

Además de los cambios en las cuatro citosinas y en los dos nucleótidos que inician la estructura secundaria, se introdujeron cambios en el plásmido pRE740 que afectan tanto a la secuencia primaria de los últimos treinta y cinco nucleótidos del extremo 3' como a su estructura secundaria, para intentar identificar bases o zonas que pudieran estar implicadas en la replicación del virus. La limitación más importante en estos experimentos es que la zona no traducida del genoma en $3^{\prime}$ ( $3^{\prime}$-UTR) es de tan sólo doce nucleótidos (Fig. 19), lo que restringe los cambios que se pueden realizar sobre la secuencia del cDNA sin que la secuencia de p91 se vea afectada. En la figura 21 se muestran algunos de los cambios introducidos de forma esquemática, con el posible plegamiento de la estructura según la modificación. Se puede ver que sólo las modificaciones que afectan drásticamente a la estructura secundaria también lo hacen a la replicación de 20S RNA, lo que indica que, efectivamente esta estructura es importante, no así la secuencia primaria, que parece no afectar. 


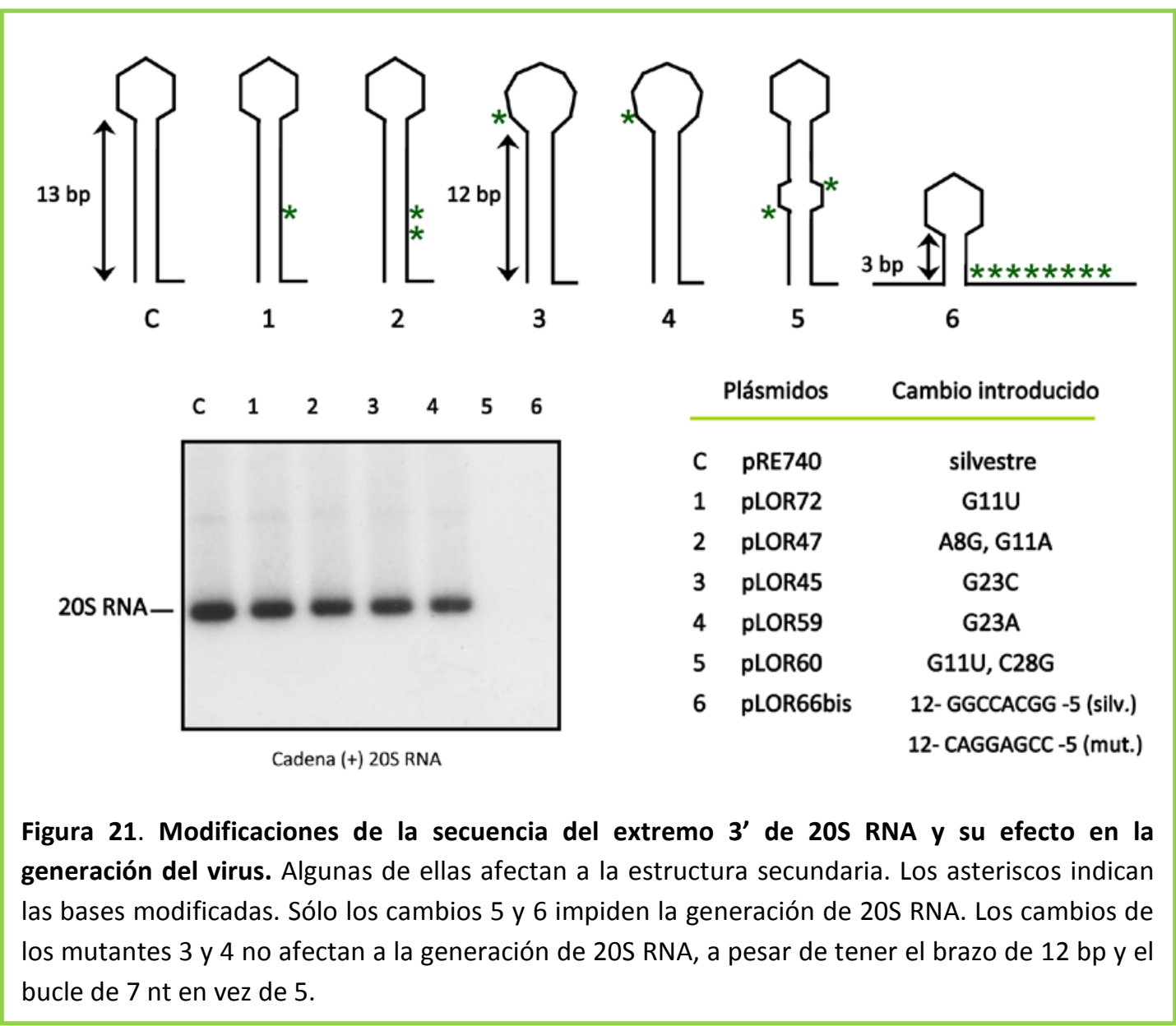

Dado que la estructura secundaria del extremo 3' es muy simple, si la comparamos con la de $23 S$ RNA (Fig. 2), es posible que existan señales en cis importantes en replicación además de en ella, en alguna otra estructura secundaria próxima al extremo 3'. Por ello, decidimos realizar algunas modificaciones en la estructura secundaria adyacente a la estudiada anteriormente (Fig. 22A), resultados que se muestran en la figura 22-B. En el diseño de todos los cambios intentamos que la estructura secundaria se modificara, bien haciéndola más fuerte por el anillamiento de nt que antes no eran complementarios o más débil abriendo zonas bicatenarias o modificando la burbuja de la horquilla. Aunque el examen no fue exahustivo, no parece que en esta zona existan señales en cis importantes en replicación, ya que en todos los casos obtuvimos generación de 20S RNA similar al control sin modificar. 


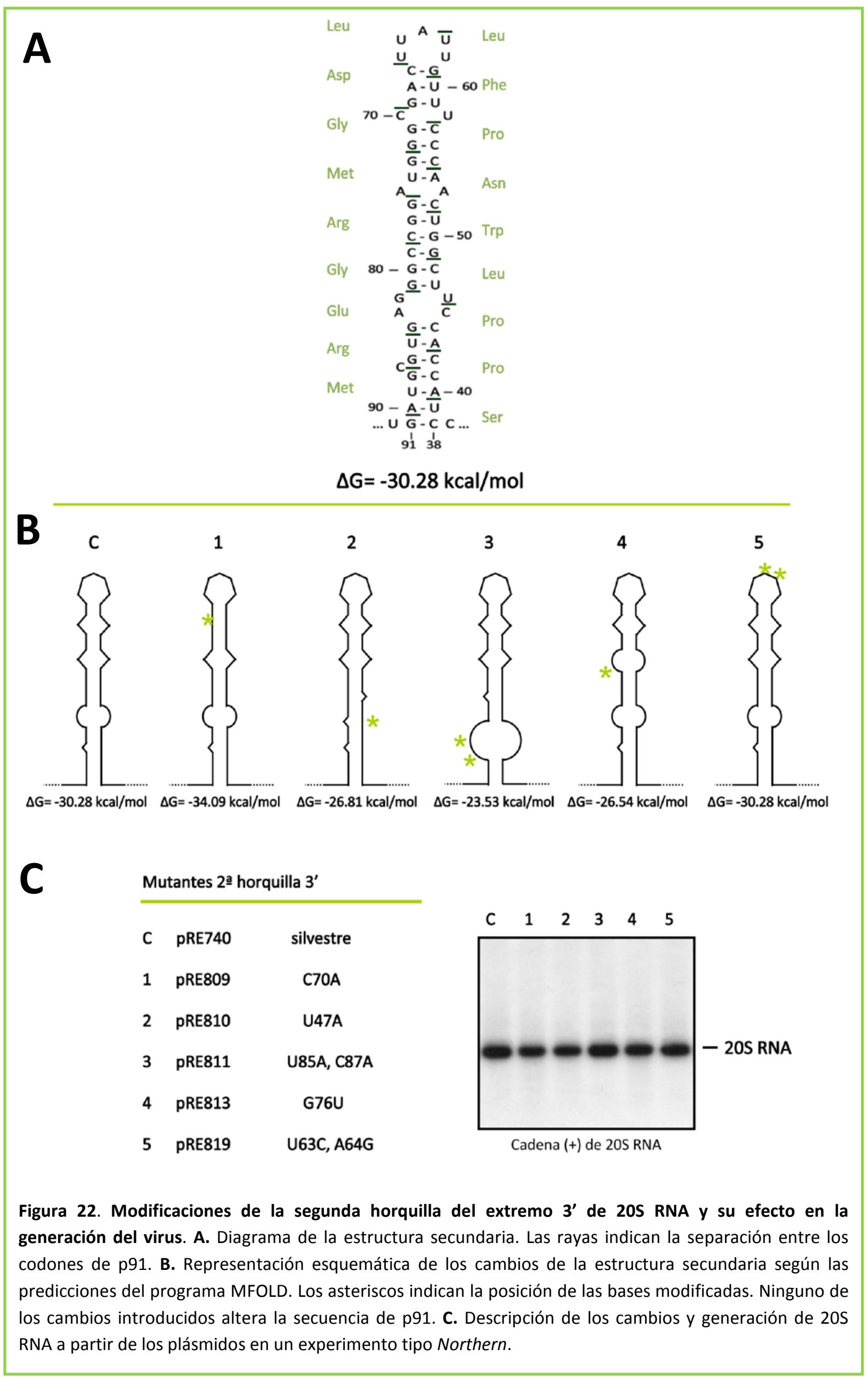




\subsection{FORMACIÓN DE COMPLEJOS p91/20S RNA}

Para profundizar en la importancia del extremo 3' del virus 20 S RNA, decidimos estudiar si algunas de las modificaciones anteriores pueden afectar a la formación de los complejos ribonucleicos p91/20S RNA. Como se ha descrito en la Introducción, los complejos entre el genoma viral y su polimerasa son clave en la supervivencia del virus, ya que probablemente su formación es esencial para la estabilización de su genoma en la célula. Estudios recientes del laboratorio con complejos parcialmente purificados han determinado que p91 se une al RNA en los extremos 5' y 3', y de una manera más débil en la zona central de la molécula (Fujimura y Esteban, 2007).

La estrategia llevada a cabo para el estudio de la formación de los complejos virales in vivo es similar a la de la generación de 20S RNA, con la diferencia de que en este caso se han modificado en el plásmido las tres bases de la secuencia de autocorte de la ribozima ( $G G G \rightarrow A A A)$, de manera que los transcritos no se procesan y tienen alrededor de 600 nt extra en el extremo 3' procedentes del vector. Este plásmido es el pLOR7 (Fig. 23). Los RNAs expresados a partir de este plásmido no pueden generar 20 S RNA debido a la secuencia extra en $3^{\prime}$, pero pueden traducirse para dar lugar a la polimerasa p91. El RNA puede formar complejos con p91 in vivo a pesar de las extensiones no virales en su extremo $3^{\prime}$. Estos complejos son similares a los que forman p91 y 20 S RNA endógenos y se pueden inmunoprecipitar utilizando anticuerpos anti-p91 (Fig. 24).

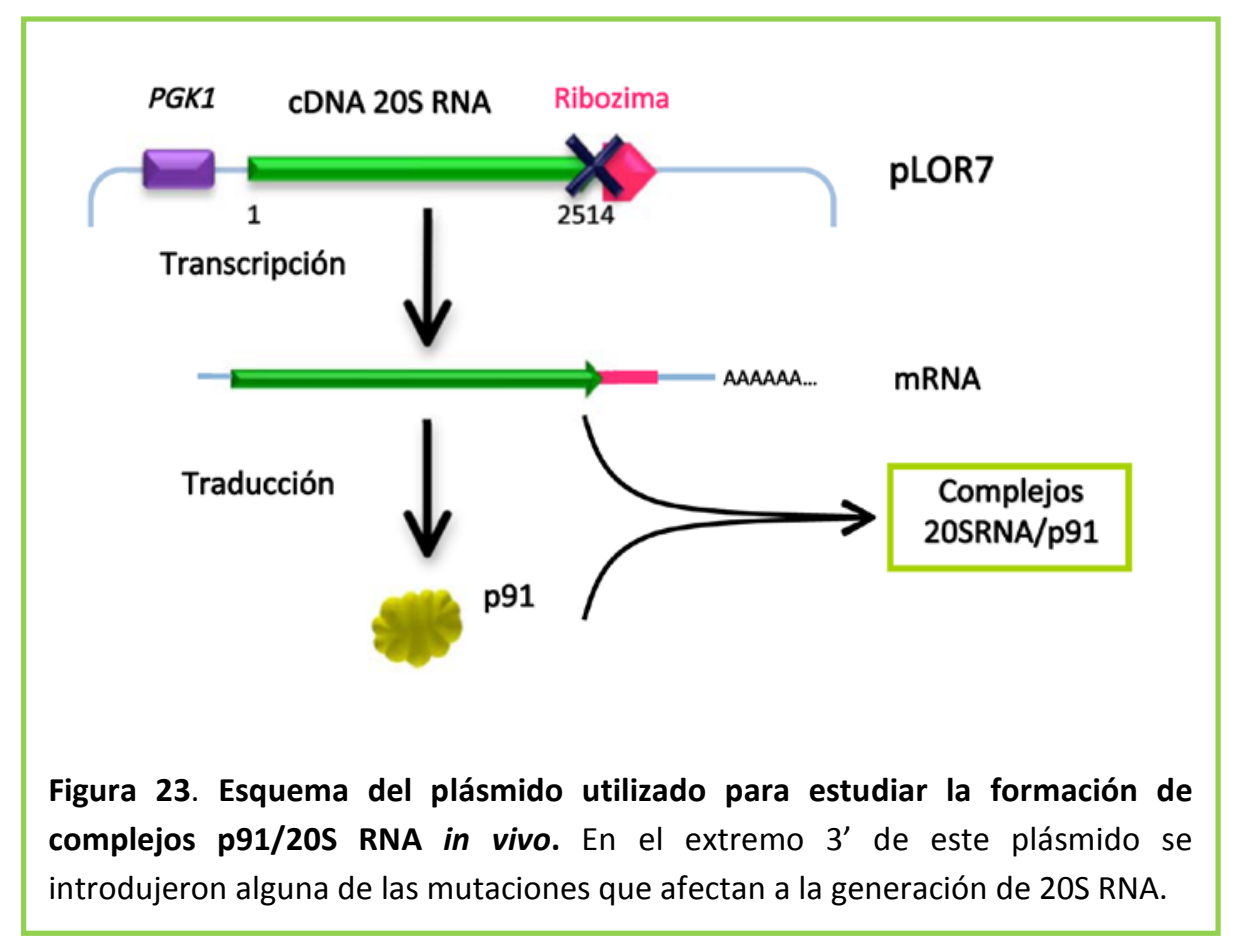




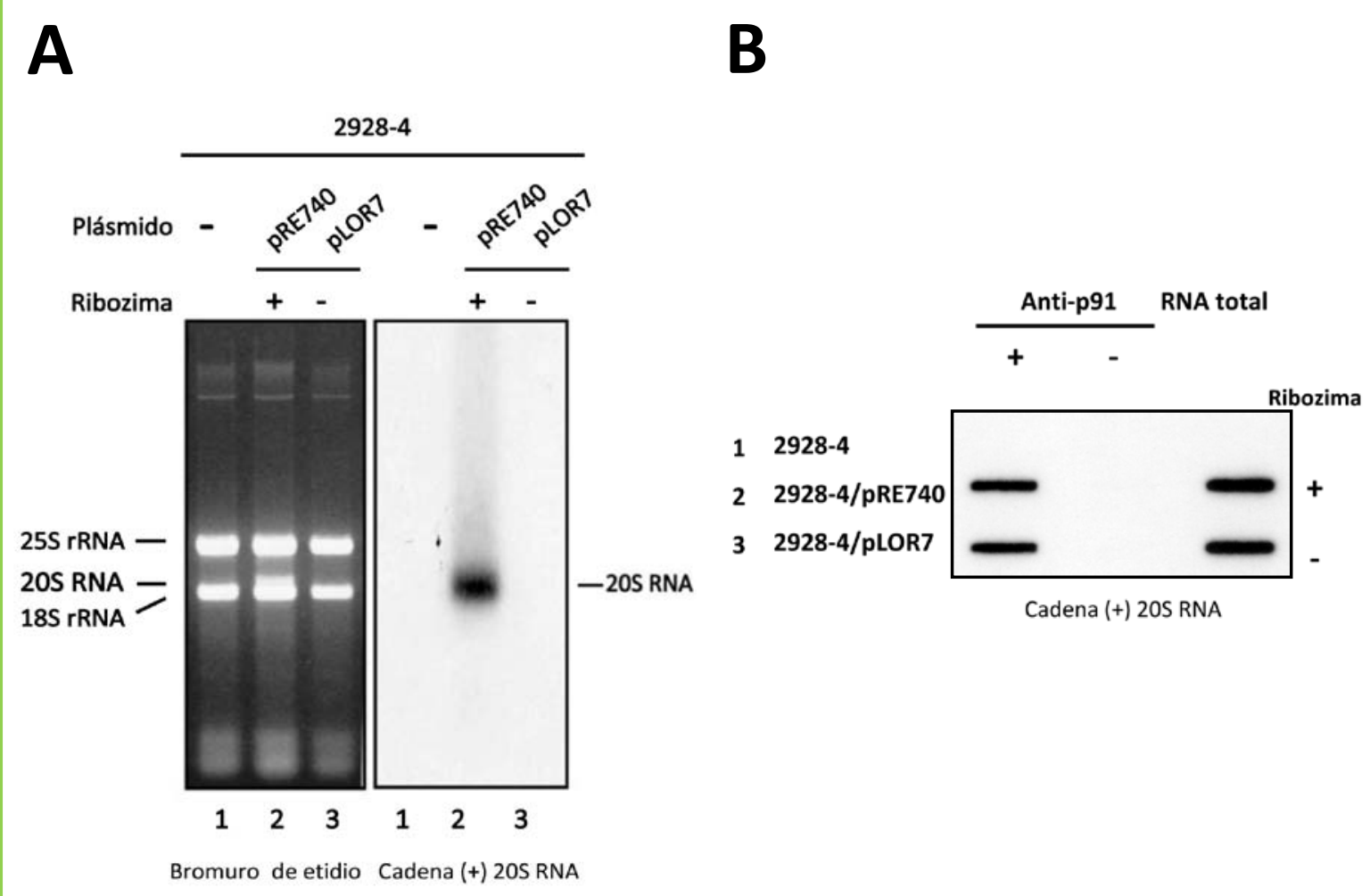

Figura 24. La generación de 20S RNA a partir de plásmidos requiere una ribozima funcional, no así la formación de complejos p91/20S RNA. A. RNAs obtenidos a partir de la cepa 2928-4 sin transformar o transformada con los plásmidos pRE740 (ribozima funcional) o pLOR7 (sin ribozima) separados en un gel de agarosa. En la cepa transformada con pRE740 se observa 20S RNA tanto en el gel teñido con bromuro de etidio como en el Northern correspondiente. El plásmido pLOR7 no genera 20S RNA debido a la secuencia extra que tienen los transcritos. B. Lisados celulares de las cepas analizadas en A obtenidos en fase logarítmica fueron inmunoprecipitados con anticuerpos anti-p91. 20S RNA se detecta en los inmunoprecipitados en un Slot Blot mediante hibridación con una sonda específica de 20S RNA. La secuencia extra del vector que no tiene ribozima no afecta a la formación de los complejos.

Con esta estrategia estudiamos la formación de complejos entre algunos de los mutantes en el extremo 3' descritos en el apartado 1.

\subsubsection{EFECTO DE LAS MODIFICACIONES DE LAS CUATRO ÚLTIMAS CITOSINAS}

Usando este sistema, se analizó el efecto de las mutaciones en las últimas bases del extremo 3' de 20 SNA en la formación de los complejos. Como se muestra en la figura 25-A, mientras que los cambios en la última y penúltima citosina no afectan a este proceso, la modificación de la tercera o cuarta citosina disminuye la formación de los complejos p91/20S RNA alrededor de un $90 \%$. El hecho de que los mutantes C3A y C4A no formen complejos con p91 puede ser la causa de la ausencia de replicación observada en el apartado 1.1. 


\subsubsection{MODIFICACIÓN DE LA ESTRUCTURA SECUNDARIA}

También se modificó la ribozima de los plásmidos empleados en el análisis de la quinta guanina, y se inmunoprecipitaron los complejos con anticuerpos anti-p91. En la figura 25-B se observa cómo en todos los casos, los cambios que afectaban a la generación de 20S RNA también impiden la formación de complejos entre el RNA y la polimerasa.

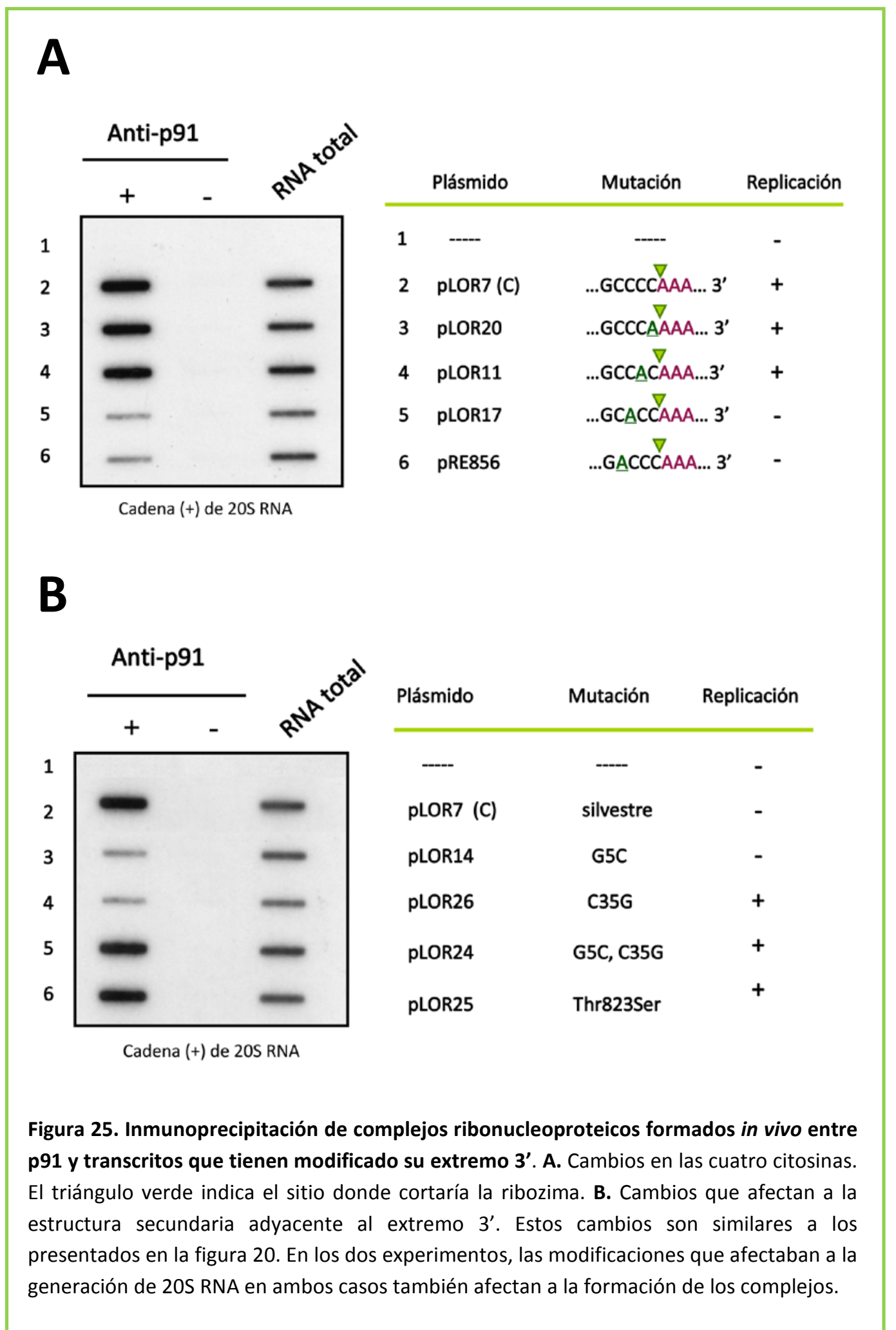


En los mutantes que no pueden generar 20S RNA se observa una formación basal de complejos p91/20S RNA (aproximadamente un 10\% respecto al silvestre) probablemente debido a la unión que tiene lugar en la parte central del RNA (Fujimura y Esteban, 2007). Además en estos casos también se observa un disminución en la cantidad de RNA total debido probablemente a que el RNA no unido puede ser atacado más fácilmente por los sistemas de degradación de la levadura.

Estos resultados, y los obtenidos en el apartado 1.1, evidencian una clara correlación entre replicación y formación de complejos p91/20S RNA. Todos los mutantes que forman complejos son capaces de generar 20S RNA expresado a partir de un plásmido, mientras que los mutantes que no los forman, tampoco pueden generar el virus.

\subsection{GENERACIÓN DE 20S RNA A PARTIR DE CADENAS DE POLARIDAD NEGATIVA}

Las cadenas de polaridad negativa (cadenas (-) son el molde para la síntesis de las cadenas (+) de los virus ss-(+)RNA, según se menciona en la Introducción. Además, datos previos de nuestro laboratorio indicaban que estas cadenas también pueden formar complejos con p91 (Garcia-Cuellar et al., 1995). Para poder estudiar las señales en cis importantes en replicación en esta cadena, intentamos generar 20S RNA a partir de plásmidos que expresan la cadena (-). Dado que ésta no puede traducirse para dar lugar a la polimerasa, se necesita un segundo plásmido como fuente de la enzima. Así diseñamos un sistema de dos plásmidos en el que uno de ellos da lugar a p91, pero esta polimerasa no puede replicar el transcrito del vector porque hemos introducido una modificación en el extremo 3', y en el otro está clonada la secuencia de la cadena (-) de 20S RNA (Fig. 26-A).

El plásmido pRE787 (expresa la polimerasa p91) contiene la modificación C4A en el extremo 3' del cDNA. p91 se puede traducir a partir de los transcritos, pero no se puede generar 20S RNA (Fig. 17). El plásmido pRE805 (molde) tiene la secuencia completa de 20S RNA pero invertida, de manera que los transcritos generados tienen la misma polaridad que las cadenas (-) del virus. Este plásmido también tiene la ribozima del HDV fusionada al extremo 3' pero el RNA expresado a partir del mismo no se puede traducir para dar p91.

Cuando la cepa 2928-4 se transforma con cualquiera de los dos plásmidos por separado, 20S RNA no se genera (Fig. 26-B), pero cuando la levadura lleva ambos plásmidos observamos la presencia de 20S RNA (Fig. 26, carril 3). La eficiencia en la generación mediante este sistema es muy alta. Después de eliminar ambos plásmidos, más del 70\% de las colonias analizadas han adquirido el virus, un porcentaje similar al encontrado en la generación de 20S RNA a partir del vector pRE740. Nuestra explicación es que los transcritos del plásmido molde (pRE805) se procesan por la acción de la ribozima, generando extremo 3' iguales a los de la cadena (-) del virus endógeno. Estas 
moléculas de RNA son reconocidas por la polimerasa producida por el otro plásmido (pRE787), que actúa en trans para producir copias de la cadena (+) a partir del molde. Estas cadenas ya se pueden traducir y replicar independientemente de los dos vectores iniciales.

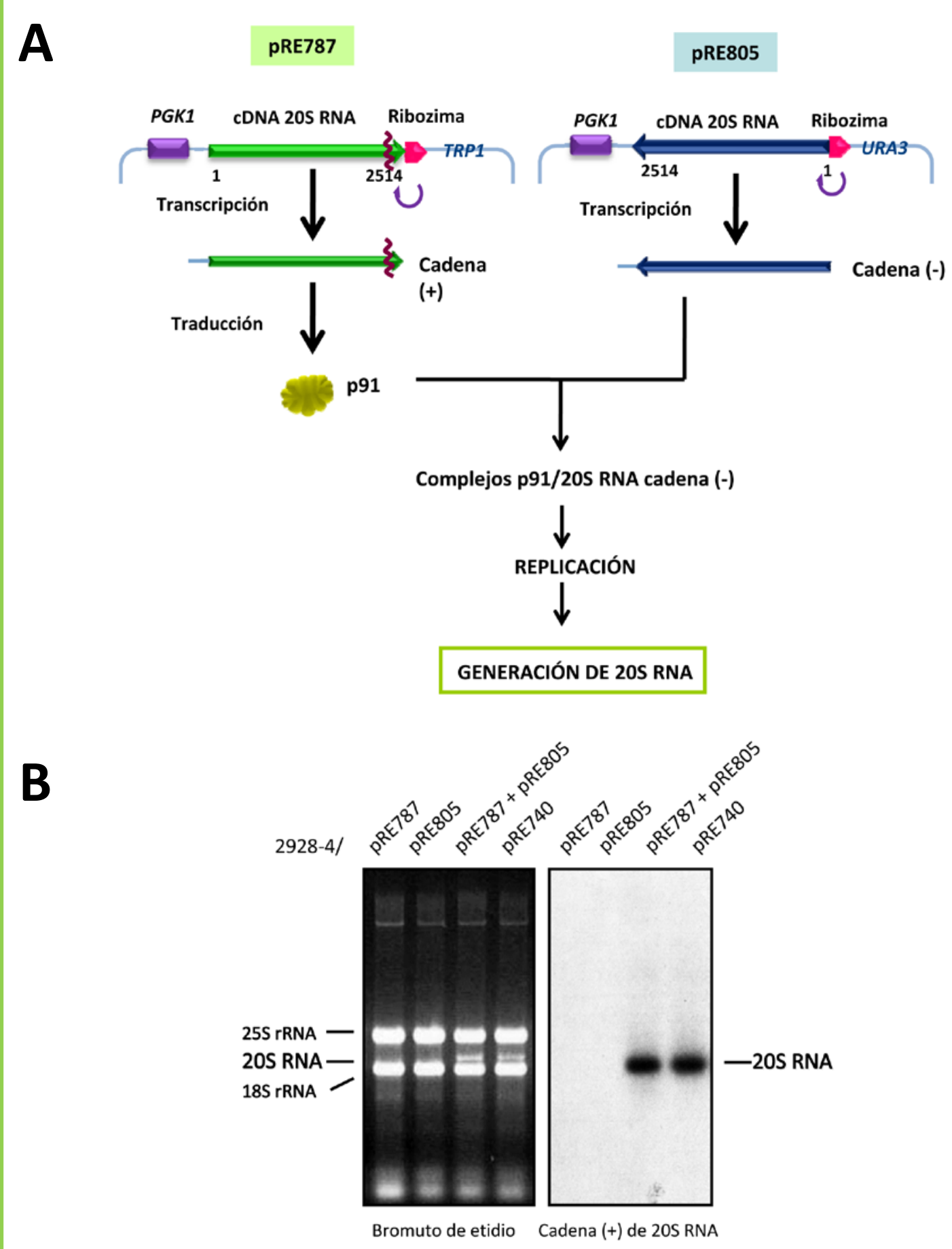

Figura 26. Generación de 20S RNA a partir de cadenas (-) en S. cerevisiae. A. Esquema de los plásmidos empleados: pRE787 expresa p91 y pRE805 da lugar a las cadenas negativas. Ambos productos de expresión se unen para formar complejos ribonucleoproteicos que se pueden replicar y generar el virus 20S RNA. B. Análisis del RNA viral obtenido a partir de la cepa 2928-4 transformada con cada plásmido independientemente y con los dos a la vez. Sólo en este último caso se genera 20S RNA, con una cantidad similar a la obtenida al transformar con el plásmido estándar pRE740. 
Para demostrar que el virus 20S RNA generado a partir del sistema de dos plásmidos procede del molde de cadena (-), el plásmido pRE805 contiene una mutación silenciosa que hemos introducido mediante mutagénesis dirigida in vitro y que lo distingue del cDNA que lleva pRE787. Así se creó un nuevo sitio Smal (T1476G) (Fig. 27). A partir de 20S RNA de la cepa transformada cpn ambos plásmidos se amplificó mediante RT-PCR un fragmento de cDNA de 842 bp donde se localiza el nuevo sitio de restricción. Previamente habíamos curado la cepa de los dos vectores de partida. Como control, también se amplificó la misma zona del genoma del virus endógeno. Cuando estos fragmentos se digirieron con Smal (Fig. 27-B), el cDNA del virus procedente de los dos vectores se digiere completamente, mientras que el del virus endógeno es resistente a la acción de la enzima. Por lo tanto, este resultado demuestra que el virus que proviene del sistema de dos plásmidos procede de las cadenas negativas, y nos valida la utilización de este vector para analizar el efecto de las mutaciones en su extremo 3' sobre la replicación de 20S RNA.

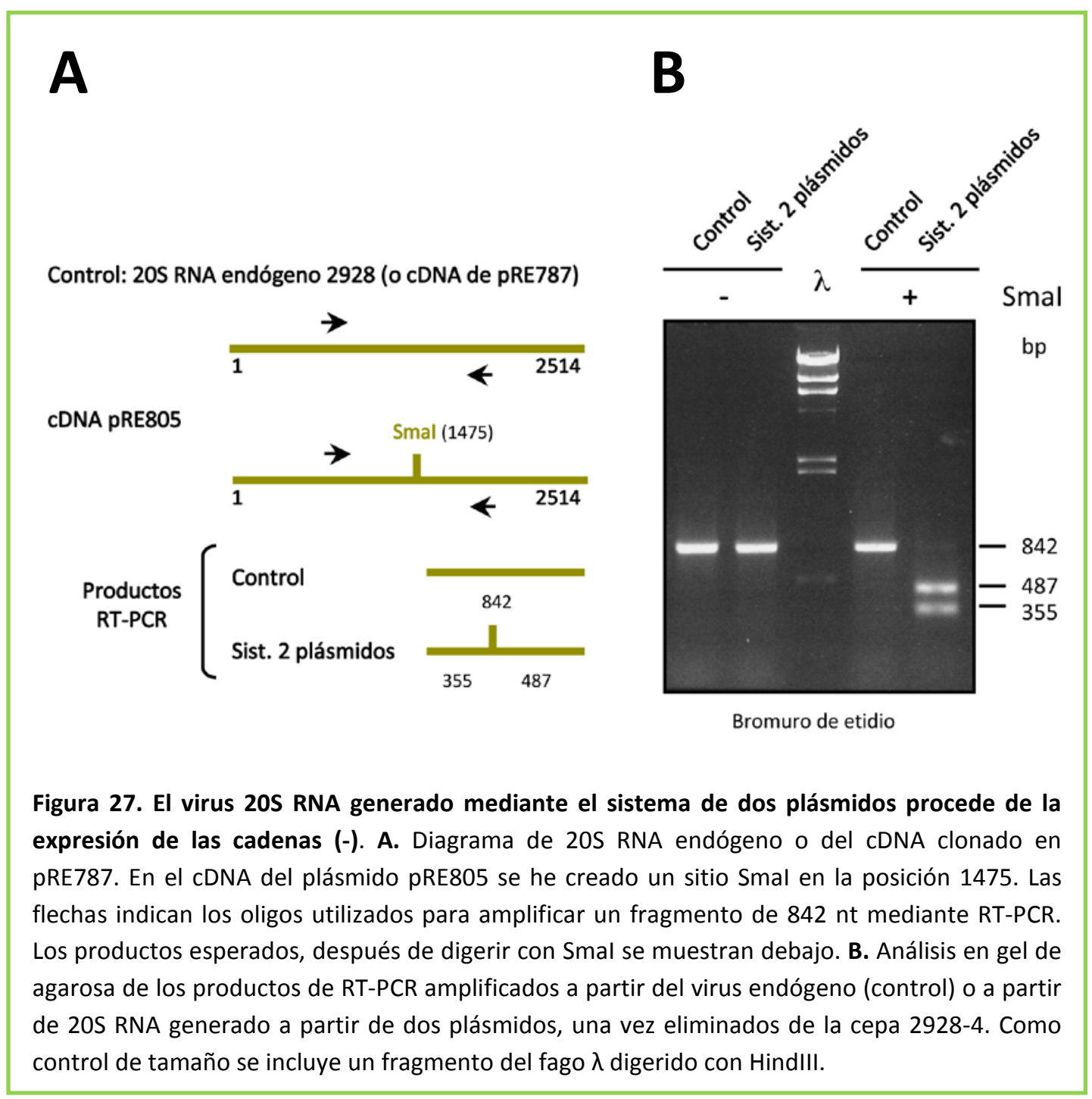




\subsubsection{EFECTO DE MODIFICACIONES DEL EXTREMO 3' DE LA CADENA (-) SOBRE LA REPLICACIÓN} DE 20 S RNA

Usando el sistema de dos plásmidos, se pueden introducir modificaciones en el cDNA que da lugar a la cadena (-) y de forma similar a los experimentos realizados con la cadena de la otra polaridad, estudiar si existen señales en cis necesarias para la replicación del virus en el extremo 3'. En el extremo 3' de la cadena (-) también existe una estructura secundaria en horquilla seguida de cuatro citosinas (Fig. 28-A). Se examinó el papel de las cuatro citosinas modificando cada una de ellas a adenina. Encontramos que los cambios en la tercera y cuarta citosina (desde el extremo $3^{\prime}$ ) afectan a la generación del virus, mientras que los cambios de la última y penúltima no (Fig.28-B). De igual manera que en el caso de la cadena (+) pueden eliminarse del extremo 3 ' las dos últimas bases, sin afectar a la generación de 20S RNA (sólo se muestra en la figura el mutante al que le falta la última citosina, pLOR4). Estos resultados indican que la tercera y cuarta citosinas de la cadena negativa del virus son esenciales para la generación del virus, mientras que las dos últimas no lo son.

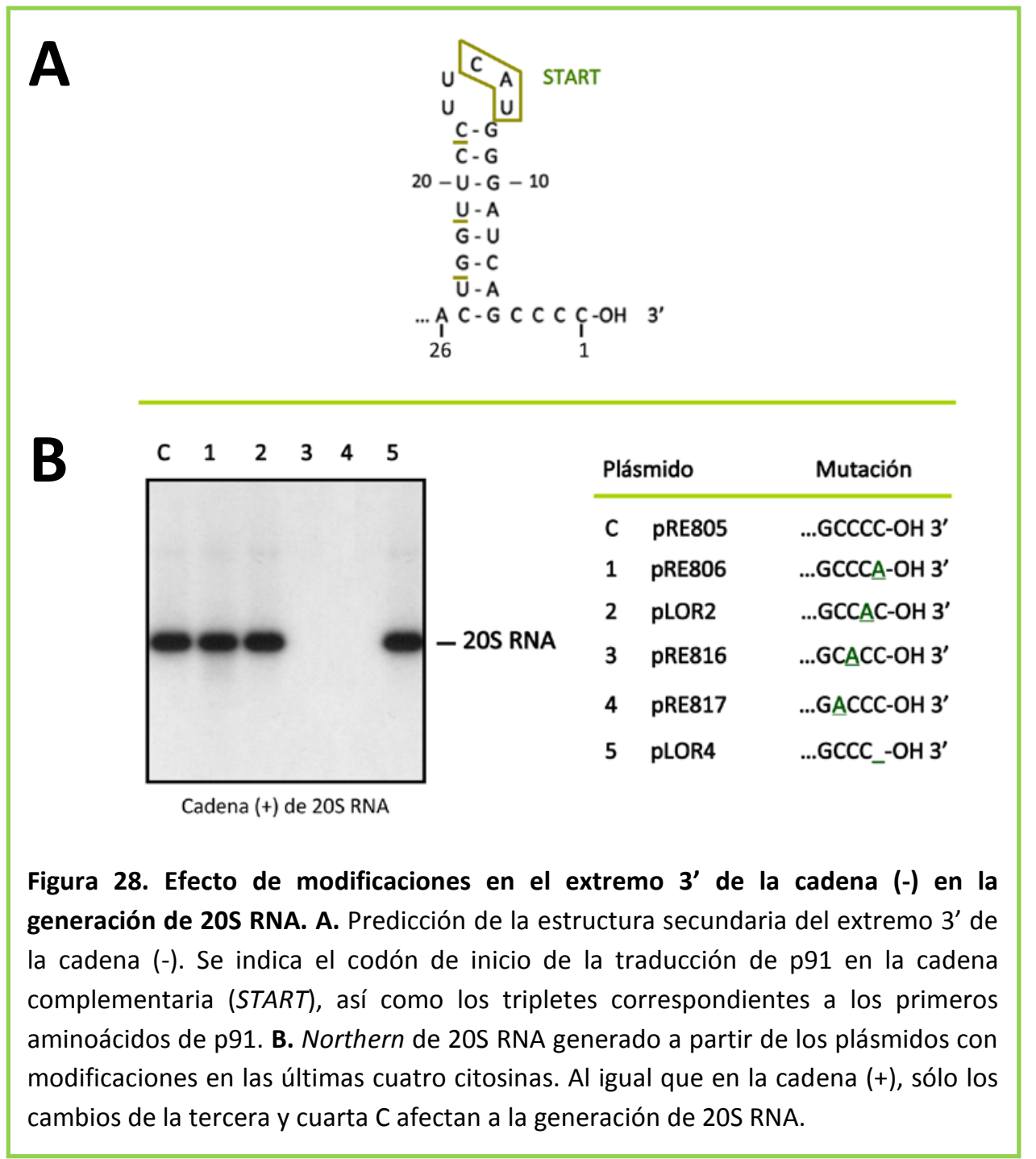


Para saber la secuencia del extremo $3^{\prime}$ de los virus generados a partir de los mutantes anteriores, se realizó un análisis 3'-RACE con RNAs de dichas cepas habiendo previamente eliminado los plásmidos de expresión. Como se muestra en la TABLA 8, los cambios de la penúltima citosina a adenina han sido corregidos y también se ha recuperado la citosina eliminada en pLOR4. Al igual que en los resultados obtenidos con la cadena (+) en este caso también debe existir un sistema de reparación del extremo $3^{\prime}$ de las cadenas (-), ya que la secuencia de los virus obtenidos a partir de los cDNAs mutados es igual a la del virus endógeno. Esto, a su vez, indica que a pesar de generarse 20S RNA a partir de RNAs a los que les faltan citosinas o están modificadas, el conjunto de las cuatro citosinas deben ser importantes en replicación, ya que se recuperan en poco tiempo.

TABLA 8. 3' RACE de algunos de los virus generados a partir de la cadena (-) de 20S RNA en S. cerevisiae.

\begin{tabular}{|c|c|c|c|c|}
\hline \multirow[b]{2}{*}{ PLÁSMIDO } & \multicolumn{2}{|c|}{ CADENA (-) } & \multicolumn{2}{|c|}{ CADENA (+) } \\
\hline & $\begin{array}{c}\text { CLONES } \\
\text { ANALIZADOS }\end{array}$ & SECUENCIA $3^{\prime}$ & $\begin{array}{c}\text { CLONES } \\
\text { ANALIZADOS }\end{array}$ & SECUENCIA 3' \\
\hline pRLOR2 (...CCAC-OH) & 8 & $\begin{array}{ll}3 & \ldots \mathrm{CCCC}-\mathrm{OH} \\
3 & \ldots \mathrm{CCCC}(\mathrm{G})-\mathrm{OH} \\
1 & \ldots \mathrm{C}--_{-}-\mathrm{OH}\end{array}$ & 6 & $\begin{array}{ll}4 & \ldots \mathrm{CCCC}-\mathrm{OH} \\
1 & \ldots \mathrm{CCCC}(\mathrm{G})-\mathrm{OH} \\
1 & \ldots \mathrm{CCC} \text { - } \mathrm{OH}\end{array}$ \\
\hline pLOR4 (...CCC_-OH) & 8 & $\begin{array}{l}6 \ldots \mathrm{CCCC}-\mathrm{OH} \\
6 \ldots \mathrm{CCCC}(\mathrm{G})-\mathrm{OH}\end{array}$ & 10 & $\begin{array}{ll}7 & \ldots . . \mathrm{CCCC}-\mathrm{OH} \\
2 & \ldots \mathrm{CCCC}(\mathrm{G})-\mathrm{OH} \\
1 & \ldots \mathrm{CCC}-\mathrm{OH}\end{array}$ \\
\hline
\end{tabular}

Ya que algunos de los clones analizados mediante 3'-RACE tenían una G extra en su extremo $3^{\prime}$ (hasta un $50 \%$ en ciertos casos), se analizó también el extremo $3^{\prime}$ de las cadenas (+) de los mismos mutantes. En algunos clones encontramos esta $G$ extra, pero en mucha menor proporción que en la cadena (-). Ahora mismo no somos capaces de explicar el significado biológico de este hecho.

\section{OTRAS MODIFICACIONES EN EL EXTREMO 3' DE LA CADENA (-) DE 20S RNA}

Al igual que en el caso de la cadena (+), se realizaron cambios en el plásmido molde pRE805 que afectan tanto a la secuencia primaria como secundaria del extremo 3'. Los cambios y el resultado de la generación de 20S RNA se muestran en la figura 29. Es importante tener en cuenta a la hora de introducir cambios en el extremo 3' de la cadena (-) que estos producirán también modificaciones en el extremo 5' de la cadena (+) y pueden afectar a la traducción de p91. En todos los cambios realizados se ha mantenido la secuencia de aminoácidos de p91 intacta. Hay casos en los que las modificaciones no afectan a la estructura secundaria del extremo 3' de la cadena (-) pero sí lo hacen a la del extremo 5' de la cadena (+) (Mutantes 1 y 3). También existe el caso contrario en los mutantes 6 y 8 . Los resultados obtenidos en todos los casos indican que sólo los cambios muy drásticos (9 y 10), afectan a la generación del virus. Estos cambios que producen una horquilla con 
un brazo de 6 bp en vez de 8 tienen dificultades para generar 20S RNA pero finalmente el virus se mantiene en cantidad similar al virus silvestre (dato no mostrado).
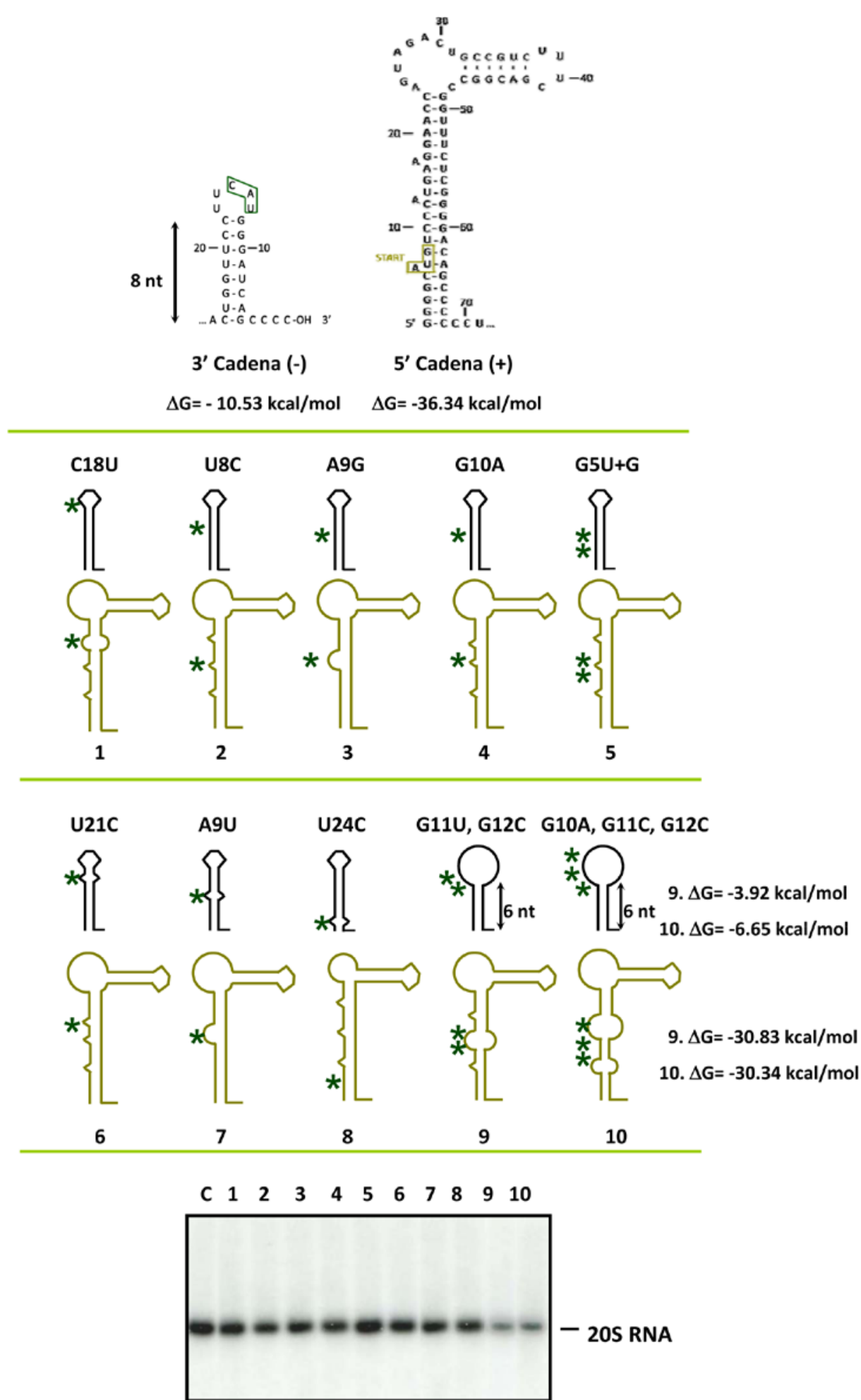

Cadena (+) de 20S RNA

Figura 29. Modificaciones de la secuencia del extremo 3' de la cadena (-) de 20S RNA y su efecto en la generación del virus. En la parte superior de la figura se muestra la predicción teórica de las estructuras secundarias del extremo $3^{\prime}$ de la cadena $(-)$ y del extremo $5^{\prime}$ de la cadena $(+)$ mediante el programa MFOLD. De cada una de las modificaciones introducidas in vitro (marcadas con asteriscos) se indican ambas predicciones, para ver si el cambio provoca cambios estructurales en el RNA. 
Dada la dificultad para estudiar en detalle esta estructura, no realizamos más mutaciones. Con algunas de las obtenidas intentamos analizar la formación de complejos ribonucleoproteicos entre las cadenas (-) expresadas a partir de vectores y p91, utilizando la aproximación experimental mostrada en la figura 23 , en la que se modifica el sitio de corte de la ribozima en el plásmido molde para evitar la generación de 20S RNA. En este caso, sin embargo, y dado que había dos vectores en las células para producir p91 y el RNA molde, nos encontramos con problemas experimentales ya que en ciertas condiciones parecía que se producía recombinación entre RNAs transcritos a partir de los mismos (a pesar de estar en orientaciones opuestas) o de promotores crípticos que estuvieran en la otra dirección. Esto nos impidió analizar con este sistema la formación de complejos p91/20S RNA cadena (-). Sin duda es una parte interesante en el estudio de los complejos p91/20S RNA que se intentará abordar en el futuro. 


\section{EFECTO DE LOS SISTEMAS DE DEGRADACIÓN DE mRNAS DE S. cerevisiae EN LA GENERACIÓN Y MANTENIMIENTO DE 20S RNA}

Como se ha comentado en la Introducción, en S. cerevisiae existen varios sistemas reponsables de la degradación de los RNA mensajeros de la célula. Decidimos estudiar si la estabilidad del genoma de 20S RNA está afectado por alguna de las exonucleasas del hospedador implicadas en estos procesos. Las responsables de esta actividad en el citoplasma de la levadura son $\operatorname{Xrn1p}\left(5^{\prime} \rightarrow 3^{\prime}\right)$ y el complejo multiproteico del exosoma $\left(3^{\prime} \rightarrow 5^{\prime}\right)$.

\subsection{EFECTO DE XRN1/SKI1}

Xrn1p/Ski1p es una exonucleasa $5^{\prime} \rightarrow 3^{\prime}$ presente en el citoplasma en $S$. cerevisiae. Como ya se ha comentado, participa en varios procesos celulares relacionados con el control de mensajeros. Ya que el sustrato de esta enzima son RNAs sin cap ni poli(A), pensamos que 20S RNA (que carece de cola de poli(A) y muy probablemente de cap) podría ser sensible a su actividad.

Para estudiar si la exonucleasa Xrn1p puede afectar de alguna manera a 20S RNA se transformó la cepa 851 (Tabla 3, Materiales y métodos), que tiene el gen XRN1 delecionado, con el plásmido pRE763 (similar a pRE740, pero su marcador seleccionable es URA3 en vez de TRP1). Mediante experimentos de tipo Northern se observó que 20S RNA se genera con gran dificultad en ese fondo genético (Fig. 30). Incluso después de sobreexponer la membrana, la cantidad de $20 \mathrm{~S}$ RNA en la cepa XRN1 $\triangle$ es mínima. Este problema en la generación del virus podría ser debido a dos causas:

1. 20S RNA necesita el gen XRN1/SKI1 para su mantenimiento o replicación.

2. La ausencia de este gen afecta a la generación del virus a partir de plásmidos.

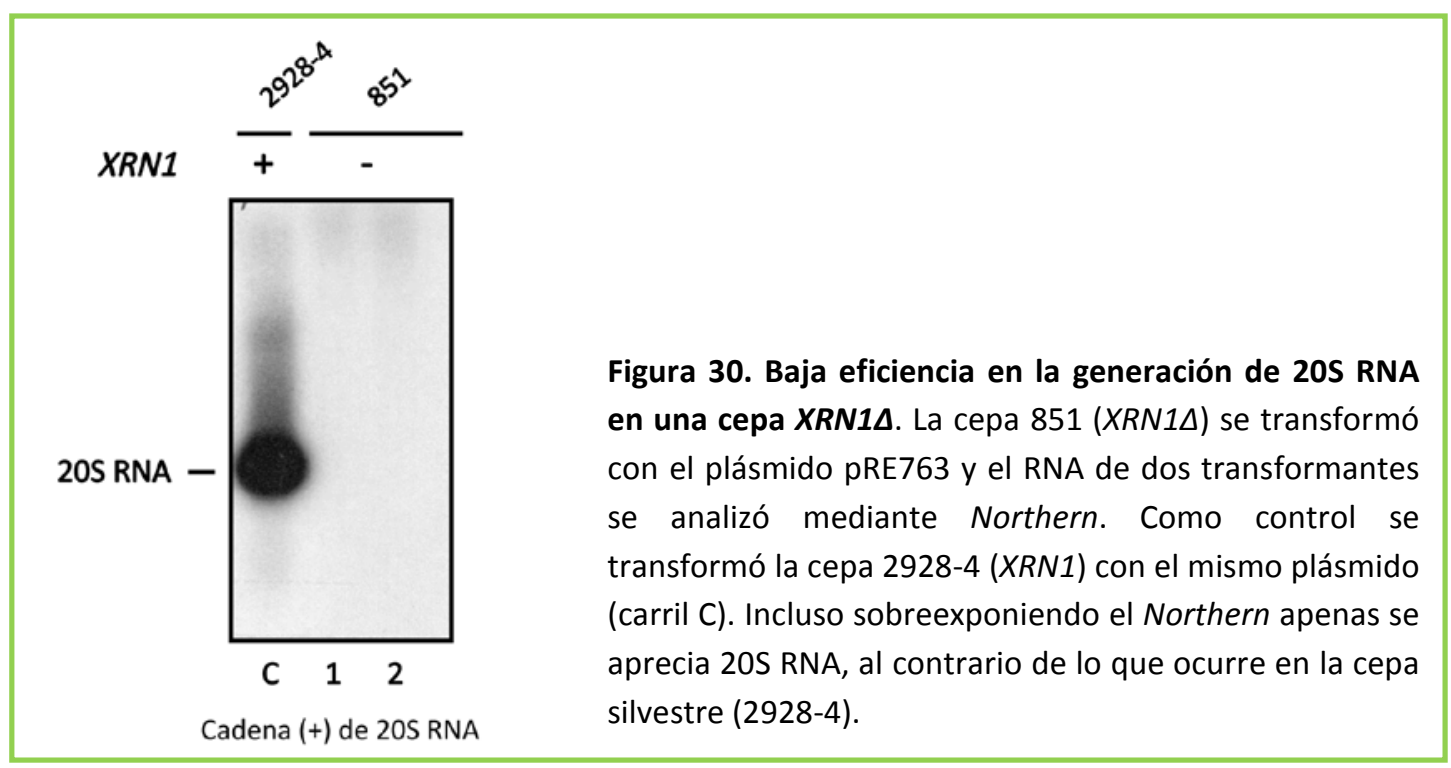




\subsubsection{EFECTO DE XRN1/SKI1 EN EL MANTENIMIENTO DE 20S RNA}

Para estudiar si Xrn1p está implicada en el mantenimiento del virus, introdujimos 20S RNA en la cepa 851 mediante dos técnicas genéticas: 1) citoducción y 2) cruzando esta cepa con otra XRN1 que contenga 20S RNA, seguido del análisis de tétradas para ver el efecto en 20S RNA de los segregantes XRN1 $\triangle$ a partir del diploide heterozigótico.

\section{CITODUCCIÓN}

Este método consiste en obtener una cepa que sin modificar su información genética nuclear lleve elementos extracromosomales procedentes de otra cepa (Conde y Fink, 1976). Así se introdujo 20S RNA a partir de la cepa 1101 ( $\alpha$ kar1-1 his4 20S RNA+) que actúa como donadora, en la 851. En la figura 31 se observa que la ausencia del gen XRN1 no afecta en absoluto al mantenimiento de 20S RNA. Esto indica por tanto, que el virus no requiere de esta exonucleasa para su replicación, ya que los tres citoducidos analizados tienen cantidades normales de 20S RNA.

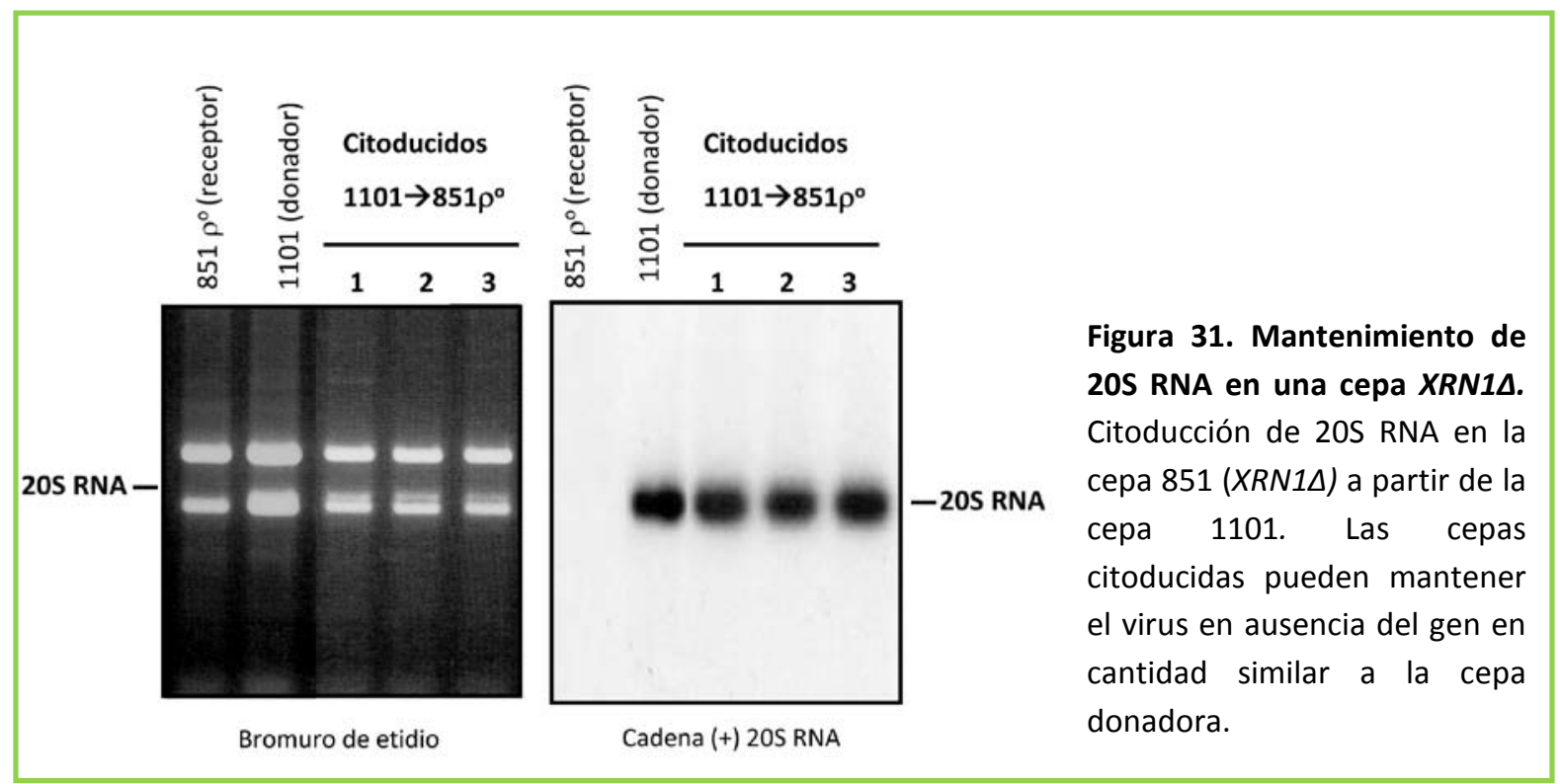

\section{SEGRGACIÓN DE 20S RNA A PARTIR DE UN DIPLOIDE HETEROZIGÓTICO XRN1/XRN1ム}

En un experimento paralelo se analizó la segregación de las ascosporas de varias tétradas en los diploides $1101 \times 851$. Los RNAs totales de las cuatro ascosporas de una tétrada se analizaron mediante Northern para determinar la cantidad de 20S RNA (Fig. 32). En los cuatro productos meióticos hay 20S RNA y además la cantidad es similar entre ellos y la cepa parental (1101), lo que indica que el virus se mantiene en las células $X R N 1 \Delta$ sin dificultad, confirmando que el problema de la generación de 20S RNA en la cepa 851 (XRN1A) no está en el mantenimiento del virus. Además parece que la ausencia del gen XRN1 no afecta significativamente al número de copias de 20S RNA 
en ese fondo genético. Probablemente el dificultad está en el proceso de generación a partir del vector.

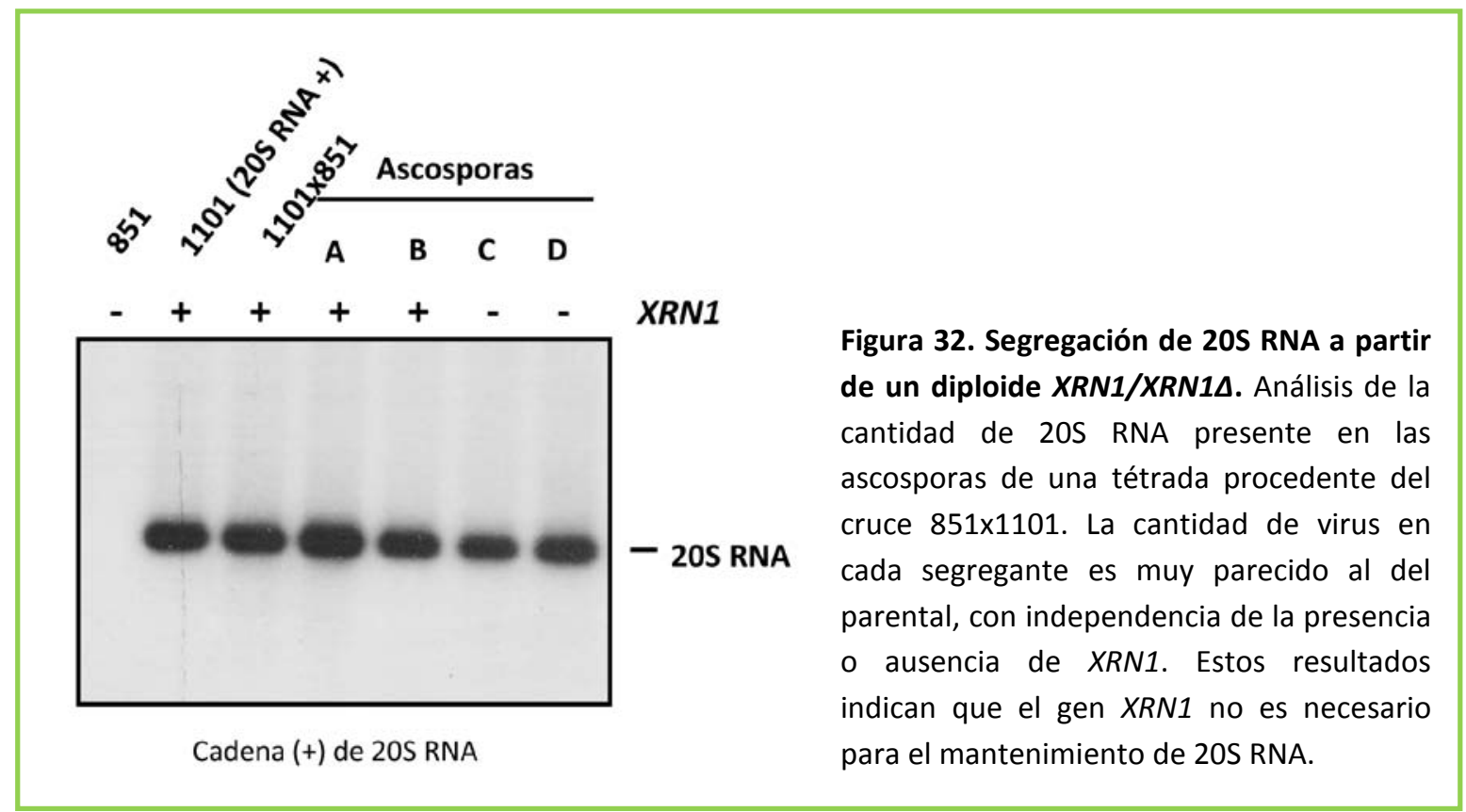

\subsubsection{EFECTO DE XRN1/SKI1 EN LA GENERACIÓN DE 20S RNA}

Como se ha comentado anteriormente, 20S RNA generado a partir de un vector de expresión tiene los extremos 5' y 3' idénticos al del virus endógeno. La producción del extremo 3' correcto se debe a la acción de la ribozima, mientras que en el extremo 5' del transcrito primario debería existir una secuencia de 47 nucleótidos procedentes del vector. Mediante experimentos de primer extension se ha comprobado que esos nucleótidos no aparecen en los virus generados, algo que podría ser debido a una eliminación física de los mismos por algún factor del hospedador o a la presencia de un promotor interno para 20S RNA en ese transcrito primario.

Nuestra hipótesis es que el factor responsable de la eliminación de los nucleótidos extra en $5^{\prime}$ podría ser la exonucleasa $5^{\prime} \rightarrow 3^{\prime} \mathrm{Xrn} 1 \mathrm{p}$, apoyado esto por los resultados negativos en la generación de $20 \mathrm{~S}$ RNA en su ausencia (Fig. 30). Para determinar cómo afecta la longitud de esta secuencia extra a la generación viral se construyeron plásmidos con tamaños decrecientes de la misma, pasando de 47 a 19, 9 y ningún nucleótido (Fig. 33-A). Con estos plásmidos (pLOR38, pLOR35 y pLOR36) se transformaron las cepas 2928-4 (silvestre) y 851 (XRN1A). Los resultadosde la figura 33-B indican que a medida que la longitud de esta secuencia es menor, la eficiencia de generación de 20S RNA en la cepa que carece del gen XRN1 aumenta, lo que sugiere que in vivo 
este gen contribuye a la eficiente generación de 20S RNA a partir de un vector de expresión. Además, en la cepa con el gen XRN1 funcional no se observa diferencia alguna en la generación de $20 \mathrm{~S}$ RNA con estos mismos plásmidos. Esto indica que en presencia de XRN1, el tamaño de la secuencia extra en $5^{\prime}$ no afecta significativamente a la generación del virus.

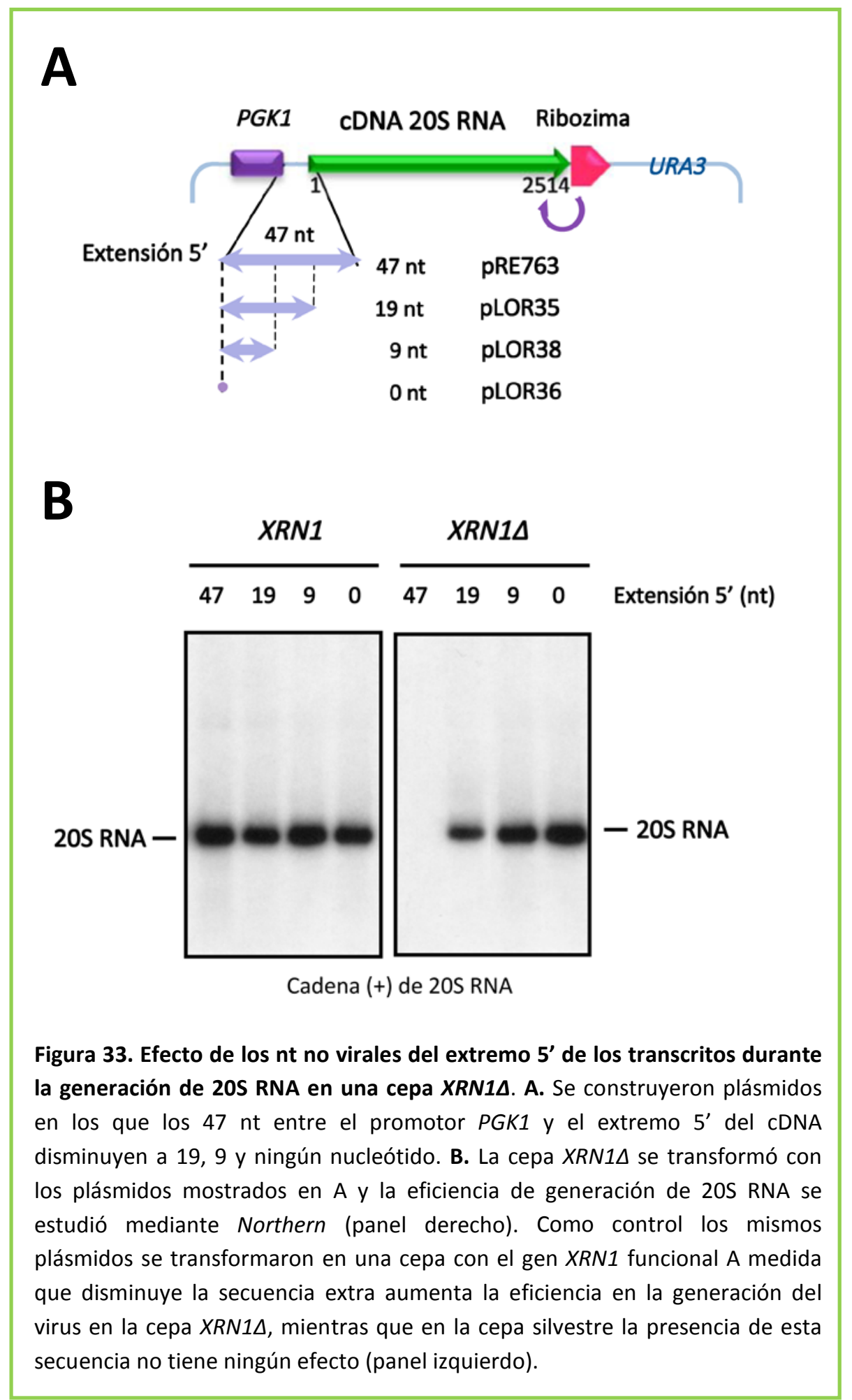


Para confirmar que la dificultad en la generación de 20S RNA en la cepa XRN1D depende realmente de la falta de actividad exonucleasa, se transformó la cepa 851 con el plásmido centromérico pRE908 que expresa la proteína Xrn1p. En esta cepa complementada ahora sí se puede generar el virus eficientemente (Fig. 34). Cuando el plásmido en el que la secuencia de la proteína contiene las mutaciones D206A y D208A (anulan la actividad exonucleasa de Xrn1p) no hay generación de 20S RNA, lo que confirma que es la ausencia de esta actividad la responsable de la disminución en la eficiencia de generación del virus, y que Xrn1p es la exonucleasa responsable de la eliminación de la secuencia no viral en 5' del plásmido pRE763 (Esteban et al., 2008).

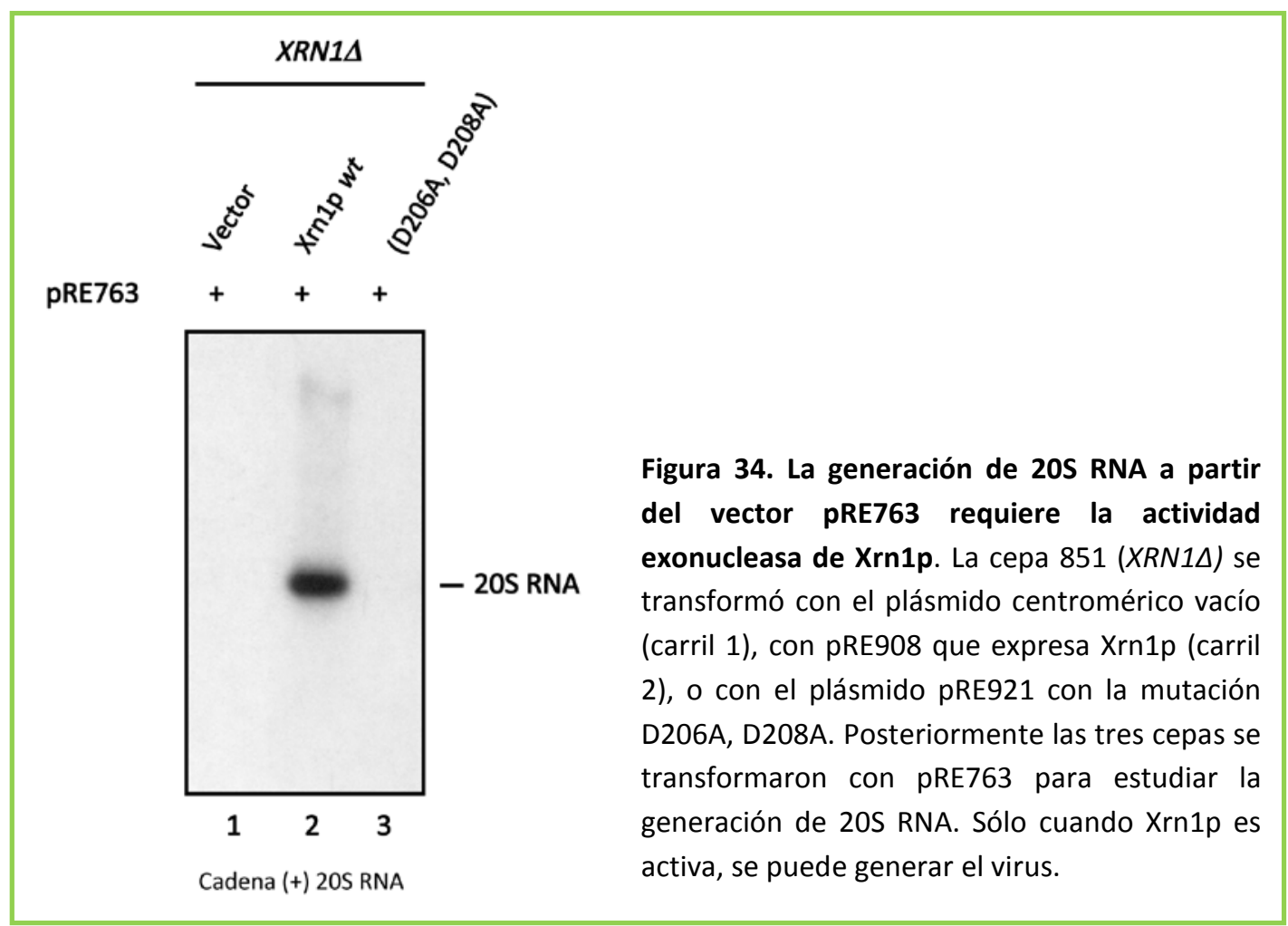

\subsubsection{EFECTO DE XRN1/SKI1 SOBRE OTROS VIRUS DE S. cerevisiae}

Los genes SKI de S. cerevisiae se describieron inicialmente como genes en los que ciertas mutaciones incrementaban la producción de la toxina killer (Toh et al., 1978). Posteriormente se comprobó que el número de copias de los virus killer (L-A y M1) y también del virus L-BC aumentaba en estos mutantes (Toh y Wickner, 1980; Widner y Wickner, 1993). Este dato es especialmente llamativo en el mutante $X R N 1 \Delta / S K I \Delta$, en el que el número de copias del virus L-A aumenta alrededor de 5 - 10 veces Fig. 35). 


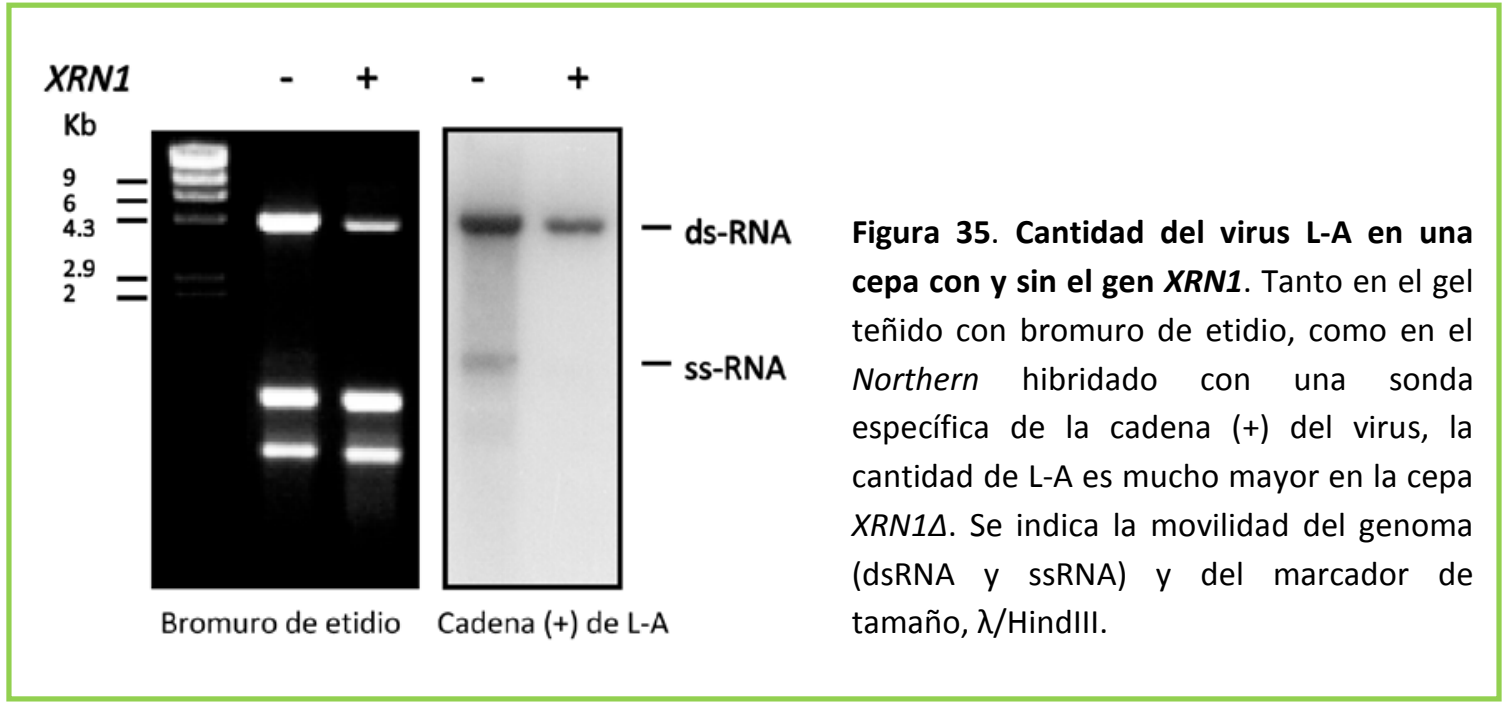

En muchos de los experimentos recogidos en esta memoria se ha eliminado este virus de las cepas de trabajo, ya que una elevada cantidad de L-A podría afectar indirectamente al estudio de $20 S$ RNA. El virus L-A se elimina normalmente por crecimiento a alta temperatura (39ㄷ). Sin embargo, las cepas $X R N 1 \Delta$ no pudimos curarlas del virus con este método, quizá porque en el proceso de eliminación de L-A se necesita esta exonucleasa. De hecho, la sobreexpresión de Xrn1p a partir del promotor PGK1 (plásmido pRE914) produce células que pierden L-A con mayor frecuencia (alrededor de un 70\%), lo que indica que este virus es muy sensible a la exonucleasa. Es interesante que la sobreexpresión de la exonucleasa elimine el virus con una alta eficiencia, mientras que $20 \mathrm{~S}$ RNA es resistente a su acción. Probablemente la respuesta a este comportamiento desigual resida en los extremos $5^{\prime}$ de ambos virus. El extremo de 20 S RNA comienza con cuatro guaninas, nucleótido que dificulta el avance de Xrn1p (Stevens, 2001), mientras que en L-A es 5' GAAAAA.... Además, el extremo $5^{\prime}$ de 20 S RNA es rico en nucleótidos $C+G$ y se encuentra formando parte de una fuerte estructura secundaria, lo que podría proteger al genoma, al contrario que L-A, cuyos extremo $5^{\prime}$ es rico en $\mathrm{A}+\mathrm{U}$ y no forman una estructura secundaria fuerte (Fig. 36).

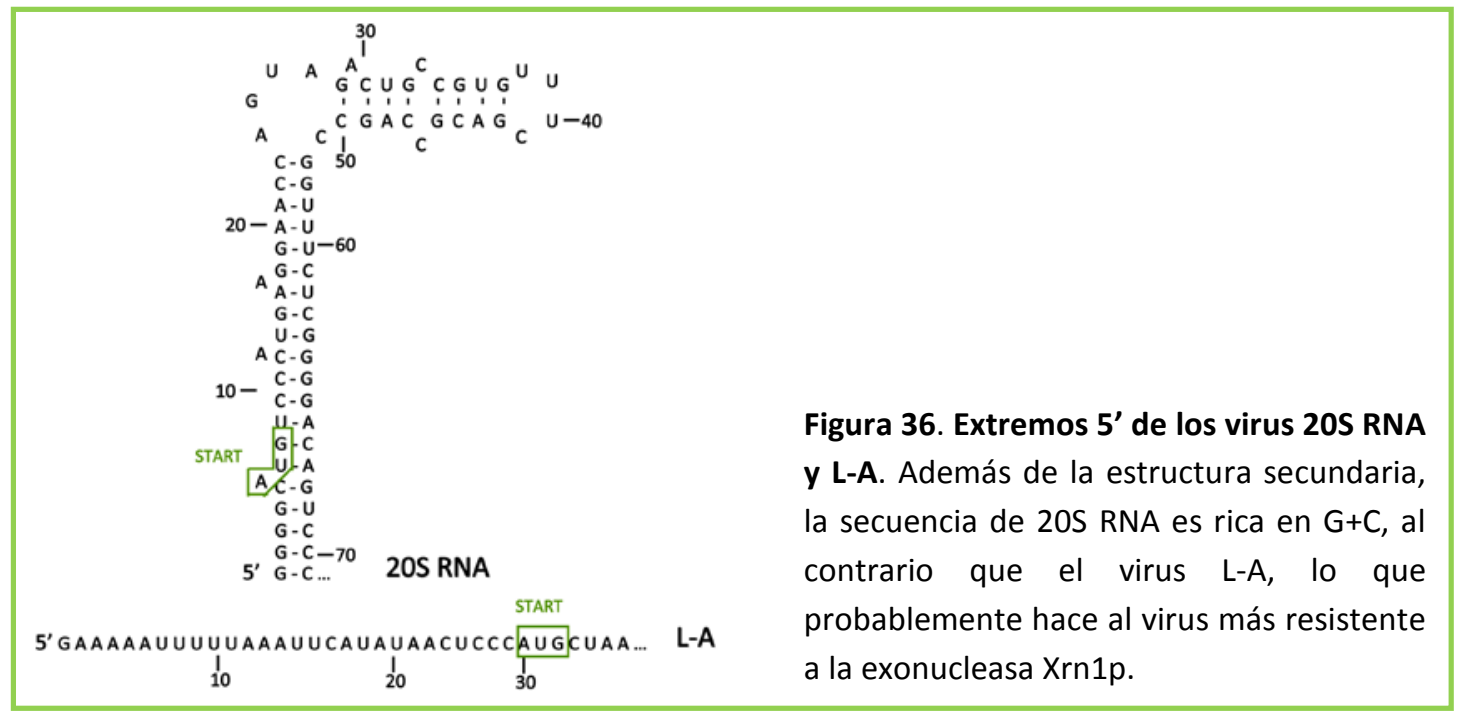




\subsection{EFECTO DEL EXOSOMA}

En la Introducción se comentó que existen tres grupos de genes $S K I$ relacionados con la actividad del exosoma en S. cerevisiae:

1 Ski4p y Ski6p: Componentes del exosoma. Ambos son esenciales. En el caso de SKI4 sólo la mutación ski4-1 es viable.

2 Complejo SKI: Regula la actividad del exosoma. Formado por las proteínas Ski2p, Ski3p y Ski8p.

3 Ski7p: Efector que interacciona con el complejo SKI y el exosoma.

No se han llevado a cabo experimentos exahustivos en cepas mutadas en genes SKI sobre 20S RNA, aunque en nuestro grupo sí se están utilizando para el estudio del otro narnavirus, 23S RNA.

Se ha comprobado que en todos los mutantes de estos genes, 20S RNA se genera con una eficiencia mayor que en la cepa silvestre (Fig. 37). Una vez generado, la cantidad del virus es siempre 2 - 5 veces superior. Así, mientras que 20S RNA es bastante resistente a $\operatorname{Xrn1p}\left(5^{\prime} \rightarrow 3^{\prime}\right)$, probablemente sea susceptible de degradarse en dirección $3^{\prime} \rightarrow 5^{\prime}$ por el exosoma. Estos genes afectan al número de copias de 20S RNA, aunque todavía falta por esclarecer cómo el virus es capaz de escapar a los mecanismos de degradación de RNAs en S. cerevisiae. Probablemente la formación de los complejos p91/20S RNA proteja el genoma viral contra la degradación.

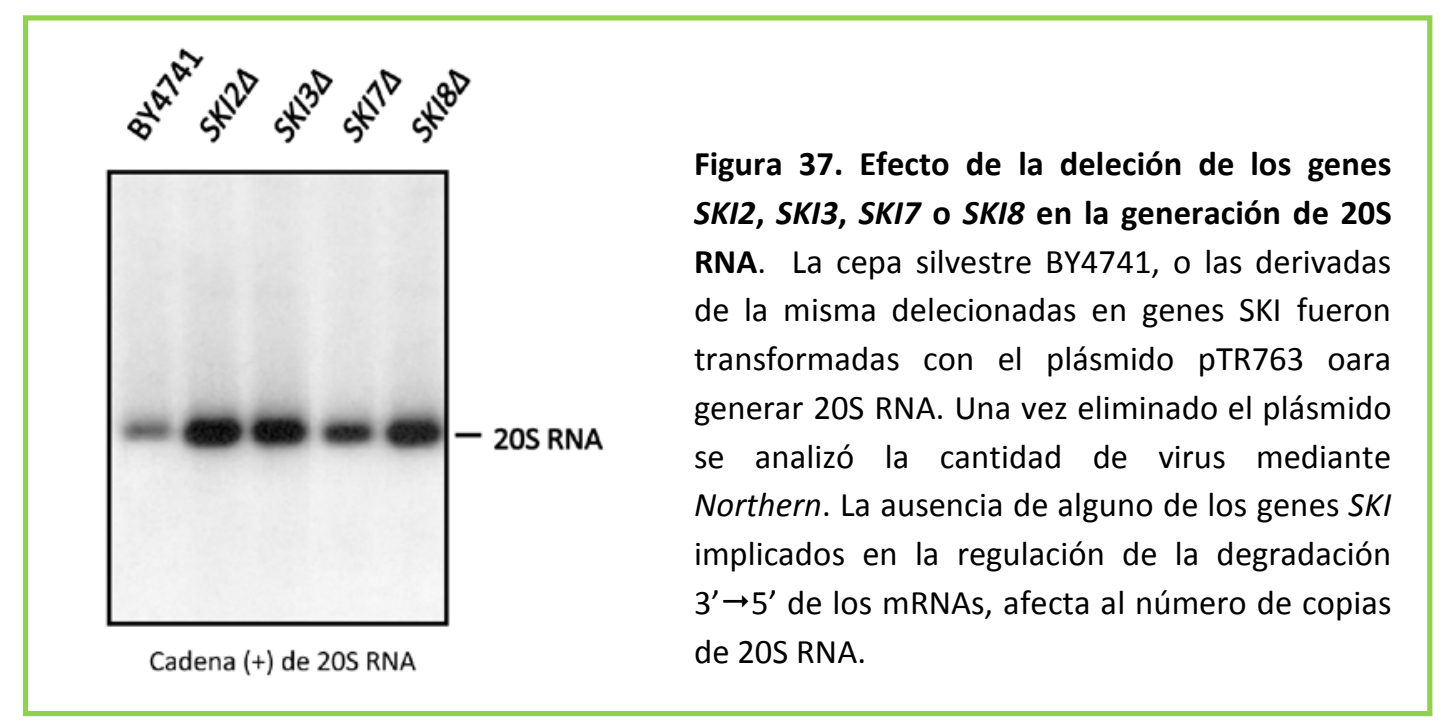




\section{IDENTIFICAR POSIBLES FACTORES DEL HOSPEDADOR FORMANDO PARTE DE LOS COMPLEJOS P91/20S RNA}

Una de las cuestiones interesantes que plantean los complejos p91/20S RNA es la posibilidad de que exista alguna proteína de $S$. cerevisiae formando parte de los mismos. Algunos resultados previos indican que probablemente el complejo se componga mayoritariamente de una molécula de polimerasa y una de RNA viral, ya que el coeficiente de sedimentación del complejo no es muy diferente al del RNA desnudo.

\subsection{INTENTOS DE PURIFICACIÓN DE LOS COMPLEJOS p91/20S RNA}

Una de las aproximaciones experimentales elegidas para estudiar las proteínas presentes en los complejos p91/20S RNA, fue su purificación. Adicionalmente esto nos permitiría abordar estudios de su estructura en el microscopio electrónico.

Las cepa elegida fue la 924 y como control su isogénica sin el virus 20S RNA, la 913 (Tabla 4, Materiales y métodos). La cepa 924 deriva de la colección de mutantes delecionados EUROFAM y carece del gen $S K I 2$. Elegimos esta cepa porque como se ha visto en el apartado 2.2, cuando se tranforma con el plásmido pRE763 la cantidad de 20S RNA es mayor que en la silvestre BY4741. Las cepas de la colección EUROFAM llevan el virus L-A, por lo que antes de iniciar los estudios de purificación eliminamos este virus por crecimiento a alta temperatura, para que su elevado número de copias en el fondo genético $S K I 2 \Delta$ no provoque una disminución de 20S RNA y además se facilite su purificación.

Los lisados celulares de las cepas 924 y 913 se sometieron a una serie de centrifugaciones diferenciales para eliminar progresivamente los restos celulares y concentrar así los complejos p91/20S RNA (Materiales y métodos, 3.12). Durante este proceso se analizaron los RNA totales y la cantidad de p91 presentes en la muestra para cuantificar el grado de purificación. Dado que nuestras condiciones de purificación están basadas en el tamaño (coeficiente de sedimentación) de los complejos, uno de los contaminantes mayoritarios son los ribosomas. La diferente proporción de los RNAs ribosomales $25 \mathrm{~S}$ y $18 \mathrm{~S}$ respecto a $20 \mathrm{~S}$ RNA ha sido utilizada para cuantificar el grado de purificación. En la figura 38 se observa que antes de cargar la muestra en el gradiente, las centrifugaciones diferenciales habían supuesto una purificación de 20 - 27 veces. 


$$
\begin{array}{lllllll}
\text { 1x } & & 4 x & & 27 x & \text { Purificación relativa } \\
\text { T } & \text { S1 } & \text { P1 } & \text { S2 } & \text { P2 } & \\
1 & 2 & 3 & 4 & 5 &
\end{array}
$$

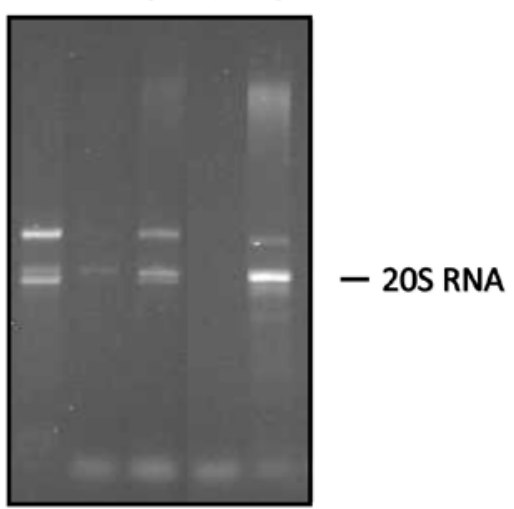

1. Lisado total (T)

2. Sobrenadante (S1)

3. Precipitado

(P1)

1 $55.000 \mathrm{rpm} 30^{\prime}$

4. Sobrenadante (S2)

5. Precipitado

(P2)

2a $75.000 \mathrm{rpm} 2 \mathrm{~h}$

Bromuro de etidio

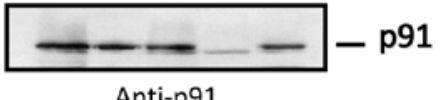

Figura 38. Enriquecimiento de los complejos p91/20S RNA mediante centrifugaciones diferenciales. En cada ultracentrifugación se observa el aumento del grado de purificación de los complejos (RNA en el gel teñido con bromuro de etidio, y la polimerasa en el Western). A partir del lisado total $(\mathrm{T})$ se realiza una primera centrifugación para eliminar el material pesado y el sobrenadante (S1) se centrifuga de nuevo para sedimentar los complejos (P2). El grado de purificación de los complejos virales es de $20-27$ veces respecto los RNAs ribosomales.

La muestra enriquecida en complejos p91/20S RNA se sedimentó a través de un gradiente de glicerol (10 - 40\%). 20 RNA y p91 presentes en las fracciones del gradiente se analizaron en geles de agarosa y acrilamida respectivamente. En la figura 39 se observa que 20S RNA y la polimerasa cosedimentan en las mismas fracciones del gradiente, tal y como se había descrito previamente (Garcia-Cuellar et al., 1995).

Las proteínas presentes en las fracciones de las cepas 924 y 913 también se analizaron en geles de acrilamida teñidos con plata para intentar identificar proteínas que cosedimenten con p91 pero no aparezcan en esas fracciones en la cepa sin el virus. En la figura 40 se observa claramente p91 en la fracción 11. Es muy difícil la identificación de factores del hospedador específicos de la cepa 924 dada la poca resolución del gel. El resto de proteínas que le acompañan parecen también estar presentes en la cepa sin 20S RNA, lo que sugeriría que no hay asociación específica con p91. 


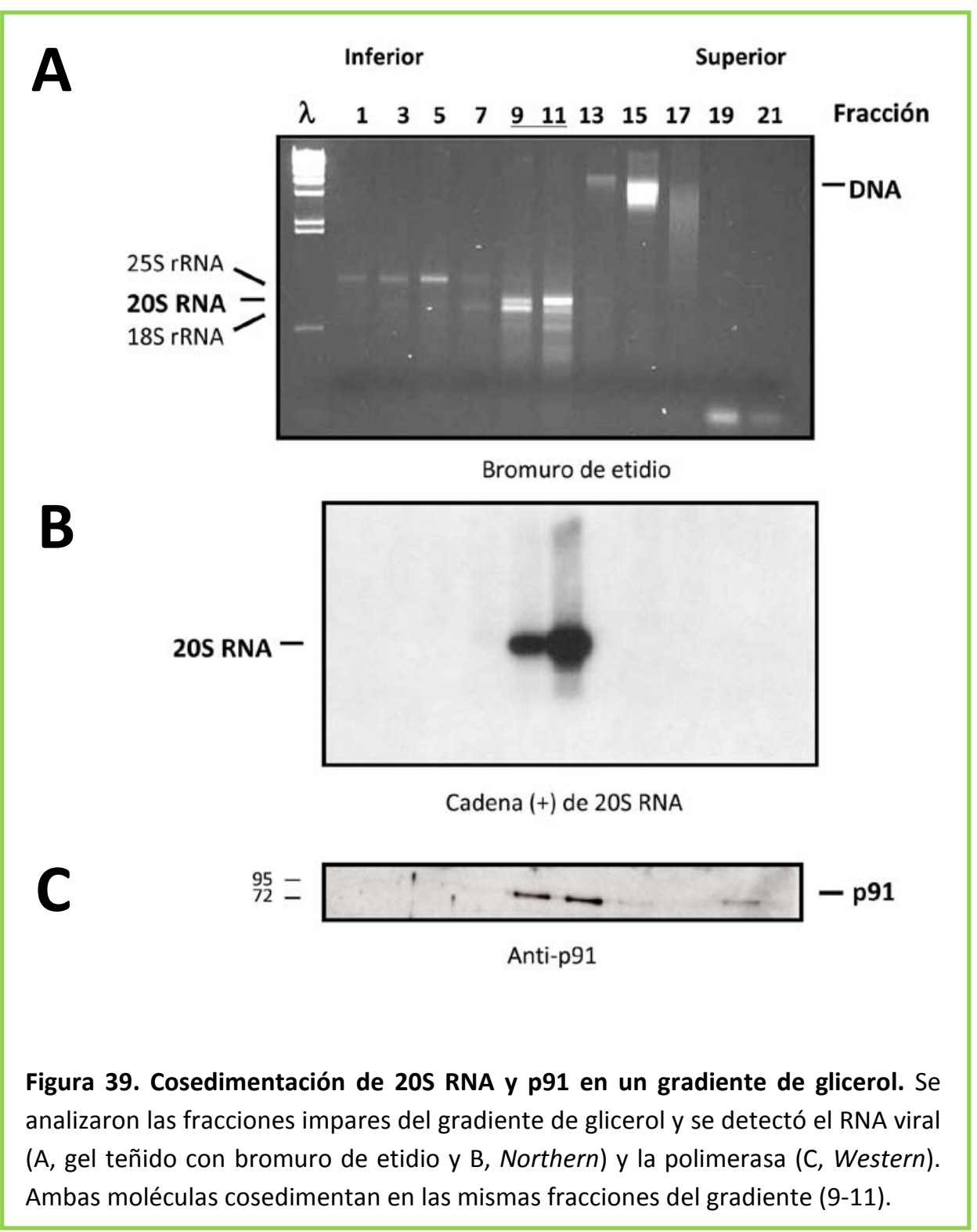

Sí que observamos en el gel teñido con plata una banda mayoritaria de alrededor de $25 \mathrm{kDa}$ que cosedimenta con p91. Datos en la literatura sugieren que se podría tratar de la proteína Hsp26p, una proteína pequeña de choque térmico (sHSP, del ingés small Heat Shock Protein) con actividad chaperona, que a pesar de cosedimentar con el virus, no está relacionada con él, ya que su presencia es independiente de 20S RNA (Widner et al., 1991). Hsp26p forma oligómeros de aproximadamente 26 unidades que se pueden ver en el microscopio electrónico como esferas de 15-25 nm diámetro (Bentley et al., 1992; Ferreira et al., 2006). Ya que nuestra idea era poder utilizar las fracciones enriquecidas en los complejos p91/20S RNA para realizar microscopía electrónica, la presencia de esta proteína podría interferir en su identificación. Por este motivo, decidimos usar una cepa HSP26A sin L-A (Cepa 950) en los experimentos de purificación de los complejos p91/20S RNA. En la parte inferior de la figura 40, entre las fracciones 9- 12 ampliadas del gel teñido con plata 
de las cepas 924 y 913, aparecen las mismas fracciones correspondientes al gradiente de glicerol de la cepa HSP26 . Al desaparecer la proteína Hsp26p, las fracciones en las que sedimentaría p91 están más limpias y se confirma que efectivamente la proteína mayoritaria era esta chaperona.

\section{S RNA}

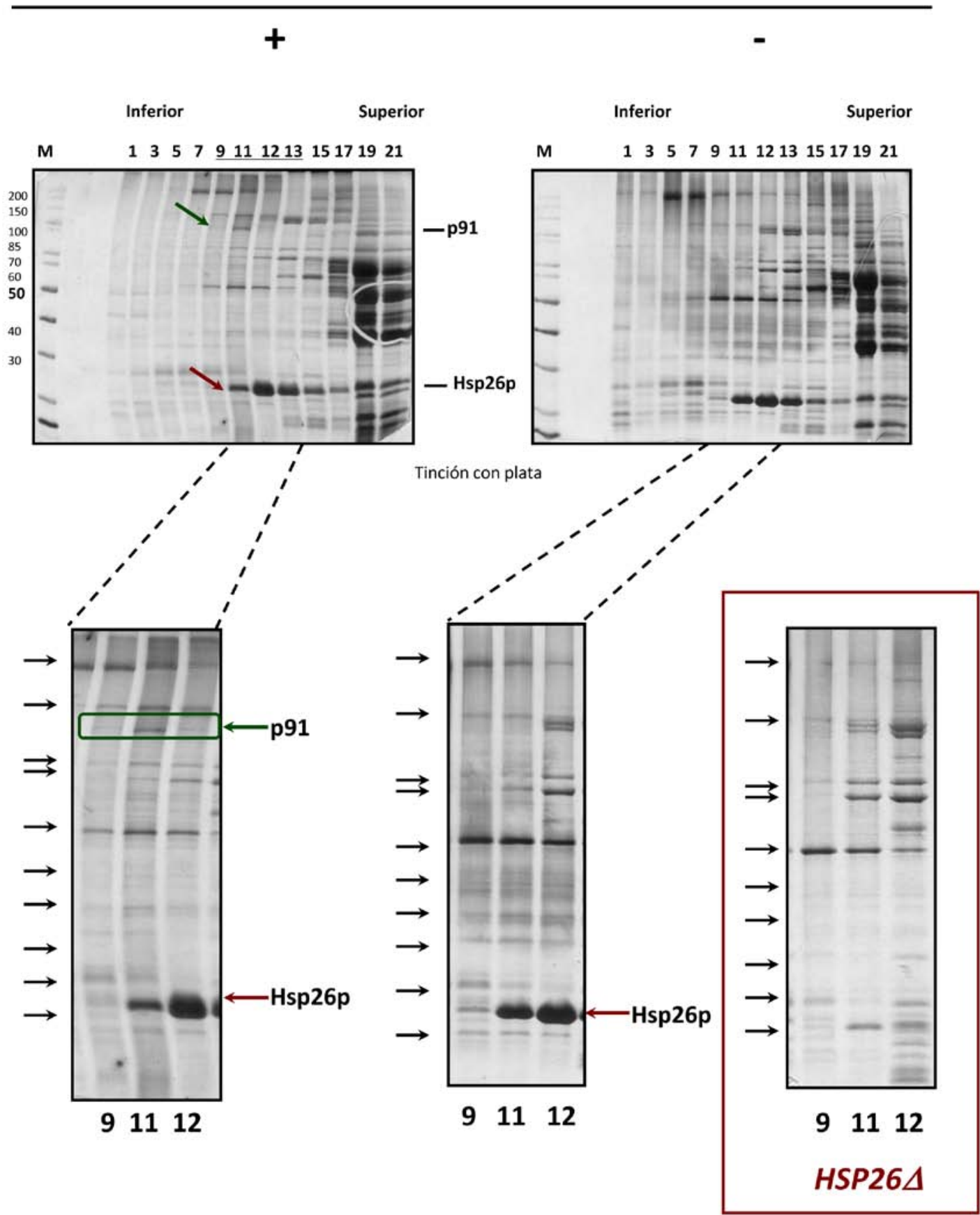

Figura 40 Tinción con plata de las proteínas del gradiente de glicerol. En las fracciones 9-12 del gradiente de la cepa 924 se aprecia una banda que corresponde con p91. El resto de bandas que cosedimentan con la polimerasa no son específicas de la presencia del virus (marcadas con flechas negras), ya que también están presentes en el gradiente de la cepa 913. En la parte inferior de la figura se muestran las fracciones 9 -12 ampliadas junto con las del gradiente de la cepa 950 (HSP264). La proteína mayoritaria de $\approx 25$ kDa que aparece en los gradientes de las cepas 924 y 913 (flecha roja) coresponde con esta chaperona. 
Nuestra idea era obtener un mutante doble SKI2 $\triangle H S P 26 \Delta$, generar 20S RNA en este fondo genético y utilizar la nueva cepa para purificar los complejos p91/20S RNA.

Durante estos intentos de purificación comprobamos que, desafortunadamente, 20S RNA se degrada parcialmente una vez recogidas las fracciones del gradiente debido a varios cortes endonucleolíticos que se reproducían en todos los experimentos (no se muestra el resultado). Esta degradación, hacía que una identificación y reconstrucción de los complejos p91/20S RNA en el microscopio electrónico fuera descartada, ya que al no conseguir mantener la molécula completa, era imposible estudiar la estructura del complejo. Además, contactamos con el Servicio de Proteómica de la Universidad de Salamanca para intentar identificar mediante espectrometría de masas las proteínas que cosedimentan con p91 en el gradiente de glicerol. Tampoco con esta técnica obtuvimos buenos resultados, ya que la cantidad de proteínas presentes en las fracciones era muy pequeña. En cualquier caso, aunque abandonamos la purificación de los complejos por este método, sí que observamos reiteradamente en todos los gradientes analizados que los patrones de proteínas en las fracciones en las que aparecía p91 era similar entre cepas con o $\sin 20 \mathrm{~S}$ RNA (compárense las flechas negras de la figura 40). Parece, por lo tanto, que no hay proteínas específicas de $S$. cerevisiae cosedimentando con p91.

\subsection{ESTUDIO DE LAS PROTEÍNAS PRESENTES EN LOS COMPLEJOS}

Otro método para estudiar los complejos p91/20S RNA es utilizar anticuerpos específicos para inmunoprecipitarlos o un kit comercial con anticuerpos conjugados que se unan a p91 y posteriormente analizar las proteínas unidas al complejo. En el apartado 3.15 .2 se detallan los pasos de este proceso, en el que se han empleado dos anticuerpos diferentes:

Anti-p91: antisuero policlonal de conejo, bien sin purificar o la IgG purificada a partir del suero.

Anti-GFP: anticuerpo monoclonal conjugado con bolitas magnéticas. Suministrado por la empresa Milteny Biotech ${ }^{\circledR}$. Cantidades y condiciones según protocolo de la casa comercial.

\subsubsection{INMUNOPRECIPITACIÓN CON ANTICUERPOS ANTI-p91}

A partir de la combinación de las fracciones del gradiente que contienen los complejos p91/20S RNA (9 - 11) y las mismas fracciones de la cepa 913, se realizó una inmunoprecipitación de una alícuota de cada muestra por duplicado, siguiendo las condiciones descritas en el apartado 3.15.2 de Materiales y métodos. p91 y las proteínas unidas a ella se separaron en geles de 
acrilamida al $10 \%$ y se tiñeron con plata. En la figura 41 aparecen varias bandas en la cepa 924 cosedimentando con p91 pero éstas corresponden al RNA de la muestra, ya que al digerir con RNAsa A las bandas desaparecen, lo que sugiere que no hay proteínas de $S$. cerevisiae formando parte del complejo además de p91. En cualquier caso esta técnica no ofrece resolución suficiente, ya que buena parte del gel está ocupada por las IgGs procedentes del antisuero que siempre están en los inmunoprecipitados.

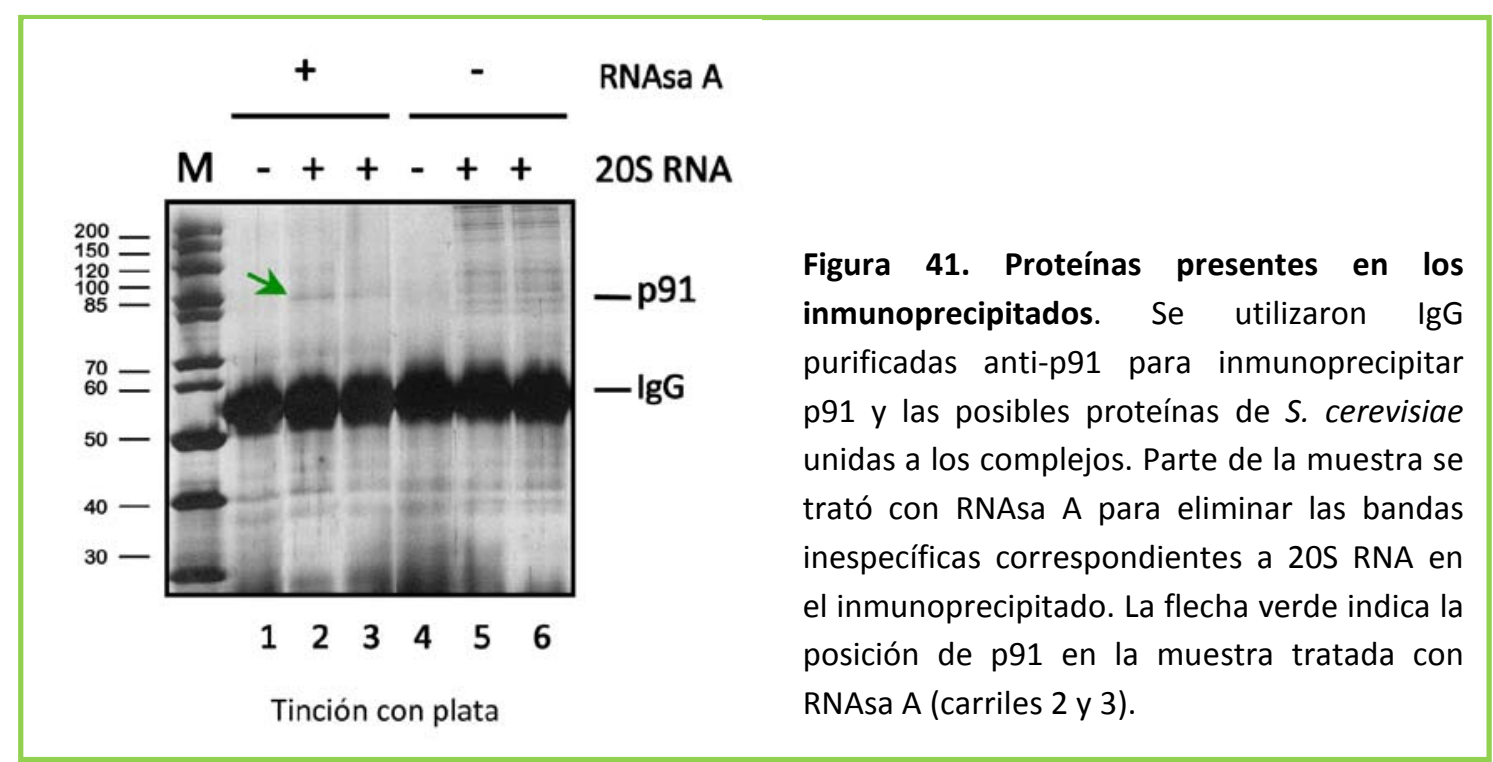

\subsubsection{INMUNOPRECIPITACIÓN DE PROTEÍNAS MARCADAS CON ${ }^{35} \mathrm{~S}$}

La posible presencia de factores del hospedador en los complejos fue estudiada siguiendo otra aproximación diferente: marcando las proteínas de las cepas en estudio (924 y 913) con el radioisótopo ${ }^{35} \mathrm{~S}$. Utilizamos una mezcla de metionina y cisteína marcadas con ${ }^{35} \mathrm{~S}$ en cultivos en medio H-Met-Cys. Después de inmunoprecipitar los complejos utilizando anticuerpos anti-p91, las proteínas unidas al complejo se pueden visualizar exponiendo el gel de acrilamida frente a una película fotográfica. Para separar adecuadamente tanto las proteínas de alto peso molecular como las de pequeño tamaño, utilizamos geles con dos porcentajes de acrilamida diferentes $7.5 \%$ y $14 \%$. La banda mayoritaria en la cepa 924 es la que corresponde a p91, mientras que las minoritarias están presentes en ambas cepas. Tanto en un gel como en el otro, no se observan proteínas coinmunoprecipitando específicamente con p91 (Fig. 42). Esto sugiere que no hay proteínas de $\boldsymbol{S}$. cerevisiae presentes en los complejos p91/20S RNA. 


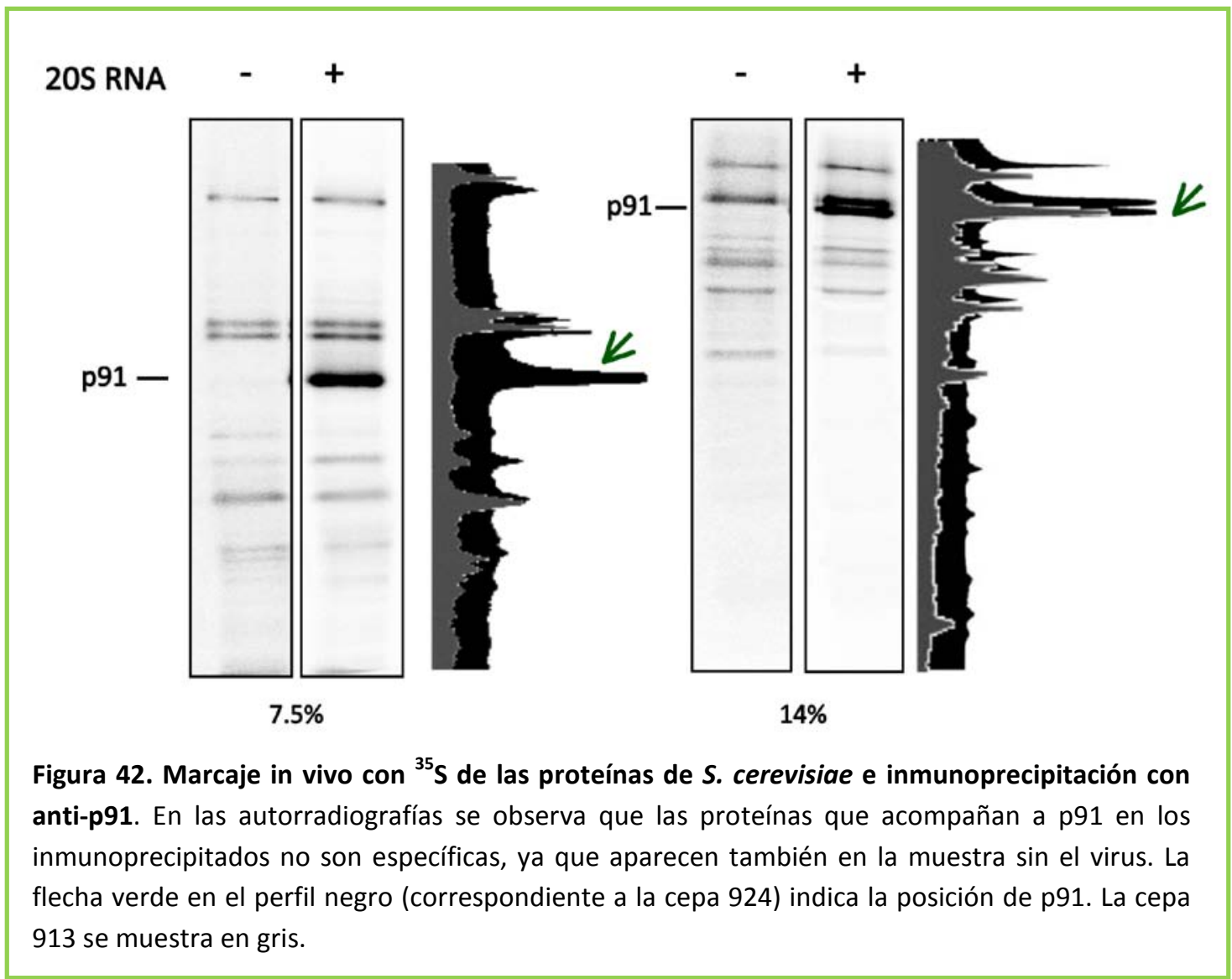

\subsubsection{ANÁLISIS DE LOS COMPLEJOS p91-GFP/20S RNA UTILIZANDO ANTICUERPOS ANTI-GFP}

En nuestro laboratorio existen plásmidos en los que p91 está etiquetada con el epítopo GFP (Green Fluorescence Protein). Esta proteína de fusión p91-GFP se expresa bien en S. cerevisiae y forma complejos con 20 S RNA (Solorzano et al., 2000). Para intentar analizar si en estos complejos se repetía el resultado obtenido en el experimento con ${ }^{35} \mathrm{~S}$, decidimos purificarlos con un kit comercial. Utilizamos el protocolo comercial de Milteny Biotech ${ }^{\circledast}$ que consiste en utilizar anticuerpos anti-GFP magnetizados, de tal manera que al eluir con un tampón apropiado, y bajo el efecto de un campo magnético, todo aquello unido al anticuerpo (proteínas marcadas con GFP y las asociadas a ellas) quedará retenido en una columna que posteriormente se eluirá con tampón de carga para proteínas y será analizado en un gel de acrilamida teñido con plata.

Se utilizaron las cepas 924 y 913 que fueron transformadas con los plásmidos pALI53 (expresa sólo la GFP, control negativo) y pALI40 (expresa p91-GFP, ver Materiales y métodos). Como se observa en la figura 43-A, no parece que existan proteínas unidas específicamente a p91-GFP. En cualquier caso, la cantidad de p91-GFP recuperada es mínima, como se observa en el Western, y por tanto las posibles proteínas asociadas también estarían muy poco representadas (Fig. 43-B). La cantidad de proteína recuperada es muy pequeña, por lo que no podemos asegurar que no haya otros factores de S. cerevisiae formando parte del complejo p91/20S RNA. 


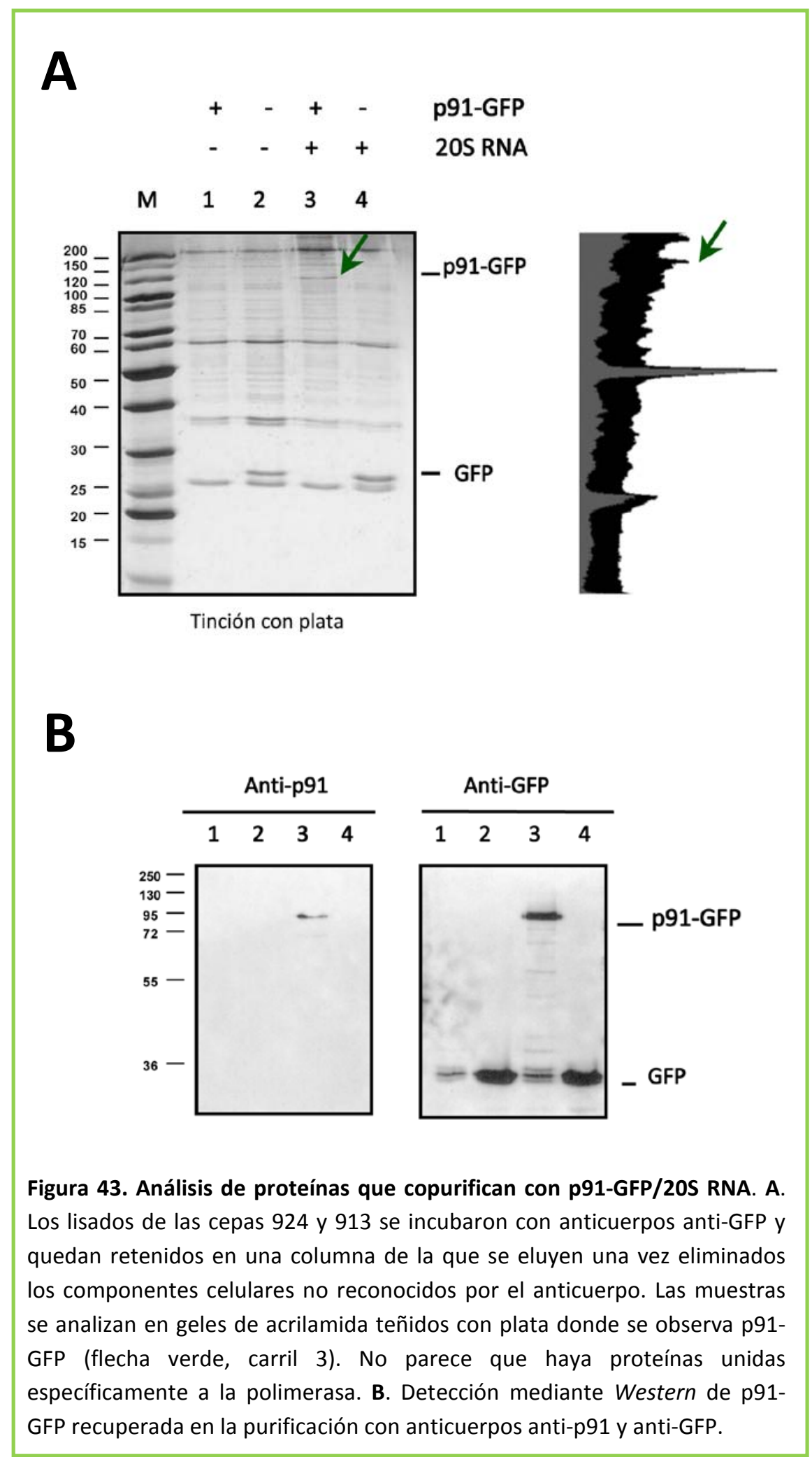

Los datos de los que disponemos hasta el momento sugieren que no hay proteínas del hospedador formando parte de los complejos p91/20S RNA. Estos resultados, sin embargo, son negativos en cuanto a que no detectamos la presencia específica de proteínas de $S$. cerevisiae de forma directa. Para poder confirmar estos resultados necesitamos un resultado positivo, es decir, 
demostrar que no se requieren factores de S. cerevisiae para la formación de los complejos. Para ello, intentamos estudiar si se podían formar en otro organismo diferente.

\subsection{FORMACIÓN DE COMPLEJOS p91/20S RNA EN UN SISTEMA HETERÓLOGO: E. coli}

Para comprobar si realmente se requieren factores de $S$. cerevisiae para formar los complejos ribonucleoproteicos p91/20S RNA, intentamos detectar su formación en otro organismo. El organismo elegido para este fin fue Escherichia coli, ya que permite la expresión de los dos componentes de los complejos, el RNA y la polimerasa de una manera sencilla a partir de vectores estándar usados en la expresión de proteínas.

\subsubsection{EXPRESIÓN DE 20S RNA Y p91 EN E. coli}

El primer paso fue la construcción de un plásmido para expresar 20S RNA y p91 en E. coli. Se obtuvieron dos versiones, la primera de ellas, pLOR91, tiene entre el promotor de la RNA polimerasa del fago T7 y el extremo $5^{\prime}$ del cDNA del virus $61 \mathrm{nt}$ entre los que se encuentra la secuencia de Shine-Dalgarno (AGGAGG) necesaria para la traducción de proteínas en procariotas. En el extremo 3' tiene la ribozima para, igual que en S. cerevisiae, generar un extremo igual al del RNA viral. También construimos un plásmido que expresa 20S RNA con los extremos 5' y 3' idénticos a los del virus. En este caso se fusionó el extremo 5' de 20S RNA directamente al promotor de la RNA polimerasa del fago T7 (pLOR92). El esquema de los plásmidos se muestra en la figura 44A.

Se transformó la cepa BL21(DE3) de E. coli con cada uno de estos plásmidos y se indujo la expresión de T7 con IPTG. Se lisaron las células y analizamos el RNA y las proteínas. Ambos plásmidos expresan enormes cantidades de 20S RNA, como se observa tanto en el gel de agarosa teñido con bromuro de etidio como en el Northern (fig. 44-B). A pesar de que la cantidad de proteínas totales es similar, según comprobamos en el gel de acrilamida teñido con azul commassie (no se muestra), mediante Western comprobamos que es necesaria la presencia de la secuencia de Shine-Dalgarno para la expresión de p91 (Fig. 44-C). Por lo tanto, decidimos utilizar el plásmido pLOR91 para estudiar si 20S RNA y p91 pueden formar complejos, a pesar de la secuencia extra en $5^{\prime}$ en los transcritos procedentes del plásmido. 
A

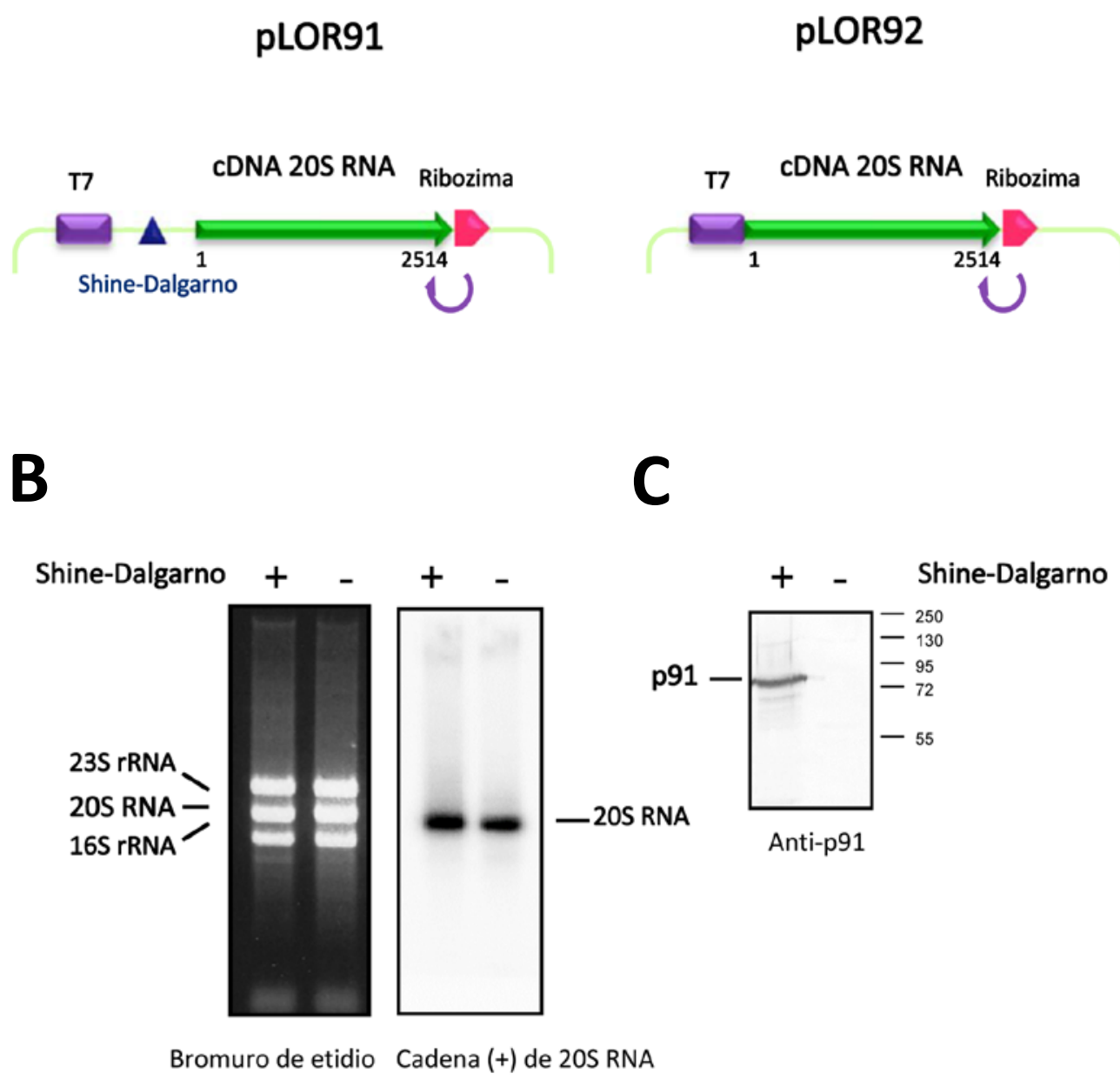

Figura 44. Expresión de p91 y 20 S RNA en E. coli. A. Diagrama de los plásmidos construídos para expresar el RNA y la polimerasa. Los dos son prácticamente iguales salvo por la secuencia de Shine-Dalgarno en pLOR91. B. Cantidad de 20S RNA expresado en E. coli. Tanto en el gel de agarosa como en el Northern se observa una gran cantidad de RNA resultado de la transcripción de los plásmidos. C. Cantidad de p91 expresada en E. coli. La secuencia de de Shine-Dalgarno es imprescindible para la traducción de p91, por lo que el plásmido que usaremos en los experimentos es pLOR91.

\subsubsection{S RNA Y p91 COSEDIMENTAN en E. coli}

El primer análisis para ver si el RNA y p91 expresados a partir de pLOR91 se encontraban unidos, fue estudiar la sedimentación en un gradiente continuo de glicerol (10\% - 40\%) similar al utilizado para analizar los complejos p91/20S RNA de S. cerevisiae. Parte de la muestra se trató con RNAsa A $(10 \mu \mathrm{g} / \mu \mathrm{l})$ antes de la centrifugación. En la figura 45 se muestra el resultado de estos 
gradientes. En la parte A se puede ver cómo 20S RNA y p91 cosedimentan en las fracciones 11, 12 y 13. En cambio, cuando el RNA ha sido digerido, la proteína está en una parte distinta del gradiente. El resultado de la muestra tratada con RNAsa sugiere que p91 y 20 SNA están asociados en E. coli. Además, esta cosedimentación depende del RNA, ya que en su ausencia la proteína migra a fracciones más ligeras del gradiente tal y como sucede en S. cerevisiae (Garcia-Cuellar et al., 1995).

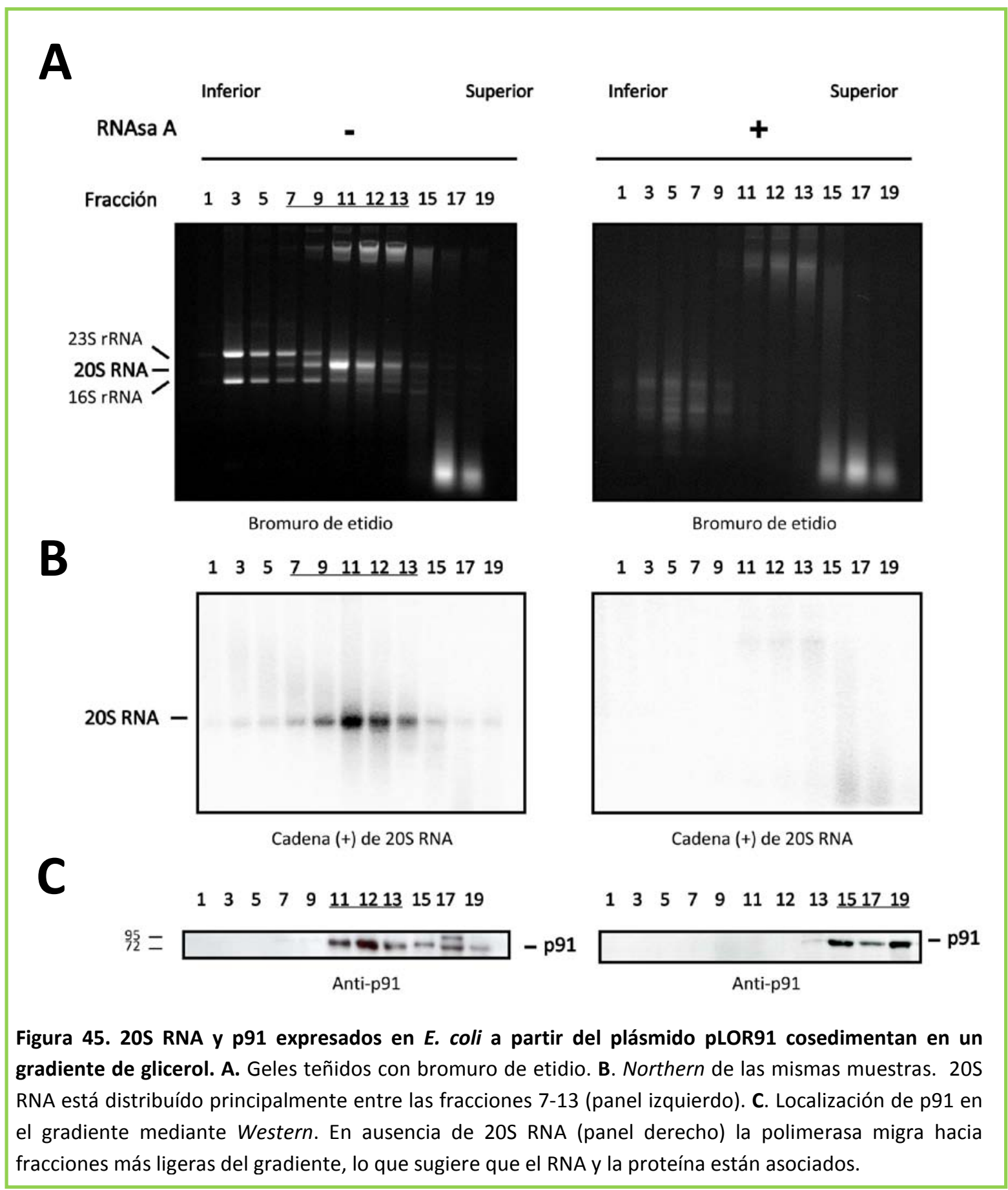




\subsubsection{INMUNOPRECIPITACIÓN DE LOS COMPLEJOS p91/20S RNA EN E. coli}

Para confirmar que 20S RNA y p91 están formando complejos en E. coli, el siguiente paso fue ver si 20S RNA se inmunoprecipitaba con anticuerpos anti-p91.

Se obtuvo el RNA de los inmunoprecipitados, y se detectó en un Dot Blot mediante una sonda específica de la cadena (+) de 20S RNA. 20 RNA está presente en el inmunoprecipitado, lo que confirma la formación de complejos en E. coli (Fig. 46). Como control positivo se utilizó un extracto de la cepa 924 de S. cerevisiae, que contiene complejos nativos 20S RNA/p91.

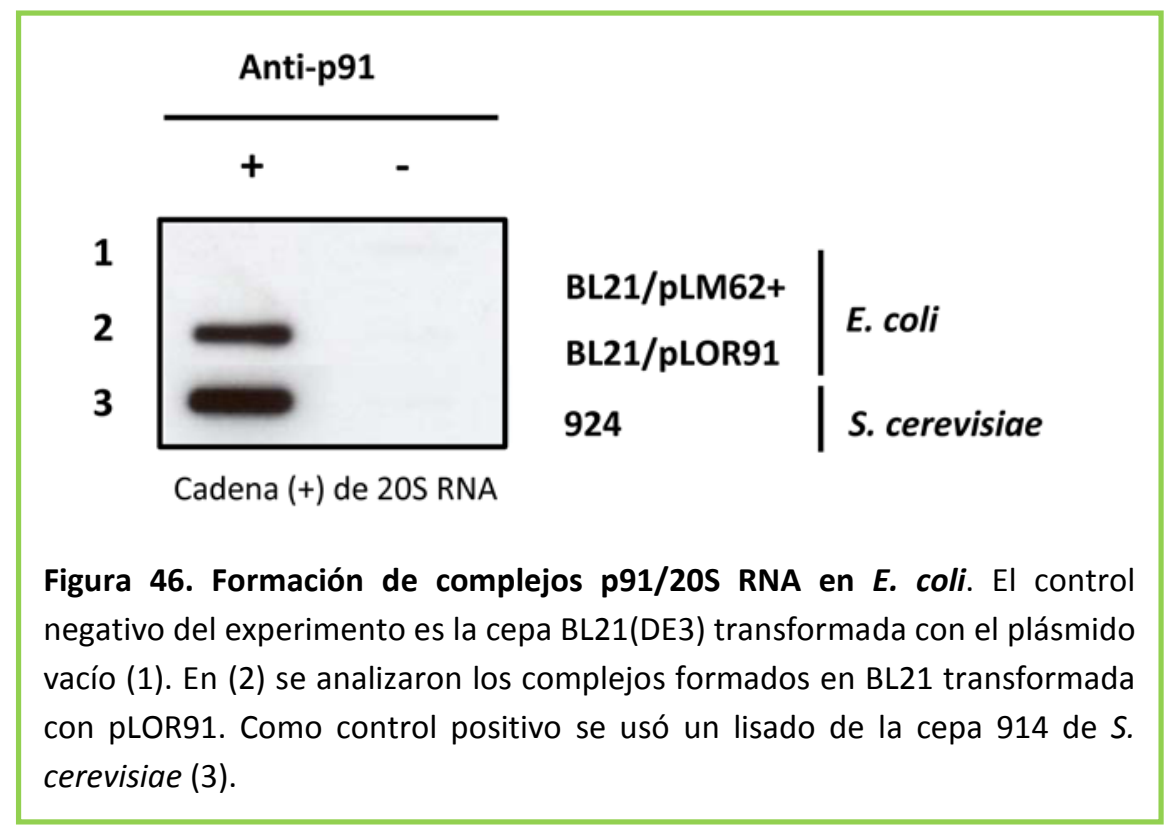

En la figura se observa que hay más cantidad de 20S RNA inmunoprecipitado a partir del lisado de S. cerevisiae que en el de E. coli, a pesar de que la transcripción de pLOR91 con T7 en esta cepa es muy elevada (Fig. 44). Esto parecería indicar que en E. coli no todo el 20 S RNA forma complejos con p91 o bien que nuestras condiciones de inmunoprecipitación (cantidad de lisado, anticuerpos anti-p91, ect...) puestas a punto para S. cerevisiae (Esteban et al., 1994) no eran las óptimas para E. coli. Por ello, en primer lugar hicimos una titulación de la cantidad de lisado y anticuerpo necesarios en la inmunoprecipitación y así poder estimar a raíz de 20S RNA presente en el inmunoprecipitado, la cantidad de complejos p91/20S RNA formados en E. coli.

En la figura 47 se muestra el resultado de esta titulación utilizando diferentes cantidades de lisado de E. coli. En estas condiciones experimentales observamos que existe una relación lineal entre la cantidad de lisado y 20 S RNA en el inmunoprecipitado, lo que valida esta técnica para cuantificar la cantidad de complejos p91/20S RNA en función del 20S RNA observado en el Dot Blot. 


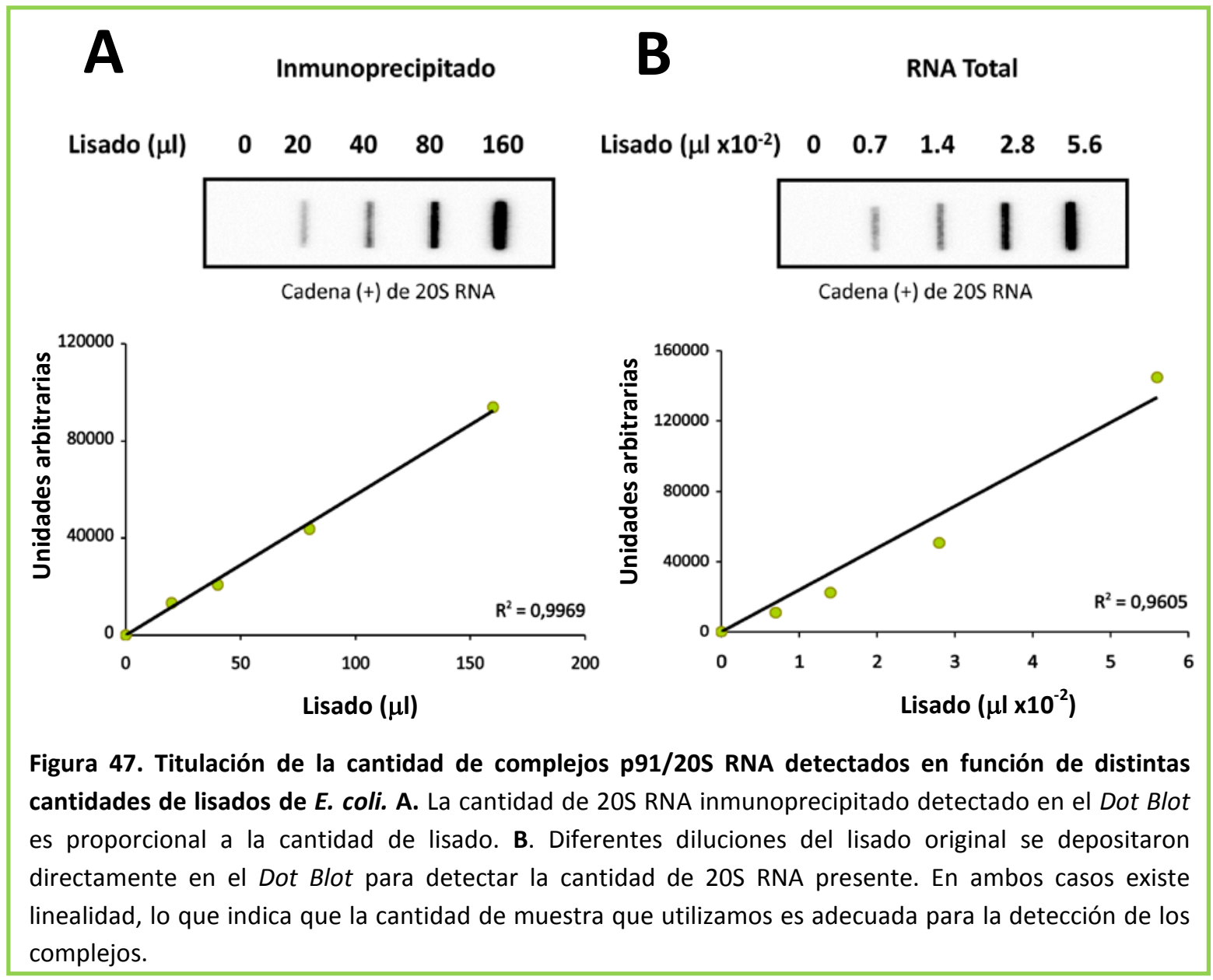

El resultado de la titulación es particularmente importante en los experimentos que se muestran a continuación, en los que estudiamos la especificidad de los complejos p91/20S RNA de E. coli que tienen mutaciones en el RNA o en la proteína expresados a partir de pLOR91.

\section{LA FORMACIÓN DE LOS COMPLEJOS ES ESPECÍFICA: MUTACIONES EN EL RNA Y LA PROTEÍNA}

Como se ha visto en el apartado 1 de los Resultados, existen ciertas zonas del genoma cuyas modificaciones afectan a la formación de los complejos p91/20S RNA en S. cerevisiae. Para comprobar si los complejos ribonucleoproteicos encontrados en $E$. coli mantienen esa especificidad, se introdujeron varios cambios en el plásmido de expresión que afectaban tanto a p91, como al extremo 3' del RNA expresado. Las modificaciones y el resultado de las mismas se muestran en la figuras 48 y 49

Los cambios que modifican p91 se muestran en la figura 48-A y consistieron en 1 ) introducir un codón de parada, de manera que se produce proteína más pequeña, de tan solo 274 aminoácidos. Esta proteína es incapaz de formar complejos porque le faltan más de dos tercios de 
la molécula. 2) En la otra modificación de p91 se alteró el centro catalítico de la enzima, o "zona GDD". Experimentos en nuestro laboratorio han demostrado que el cambio de esta secuencia por los aminoácidos EFD afectan a la actividad de p91 en S. cerevisiae (Esteban et al., 2005). Como se puede ver en la figura 48-B, la cantidad de complejos que se forman en estos dos mutantes de la polimerasa disminuye sustancialmente si los comparamos con los del silvestre.

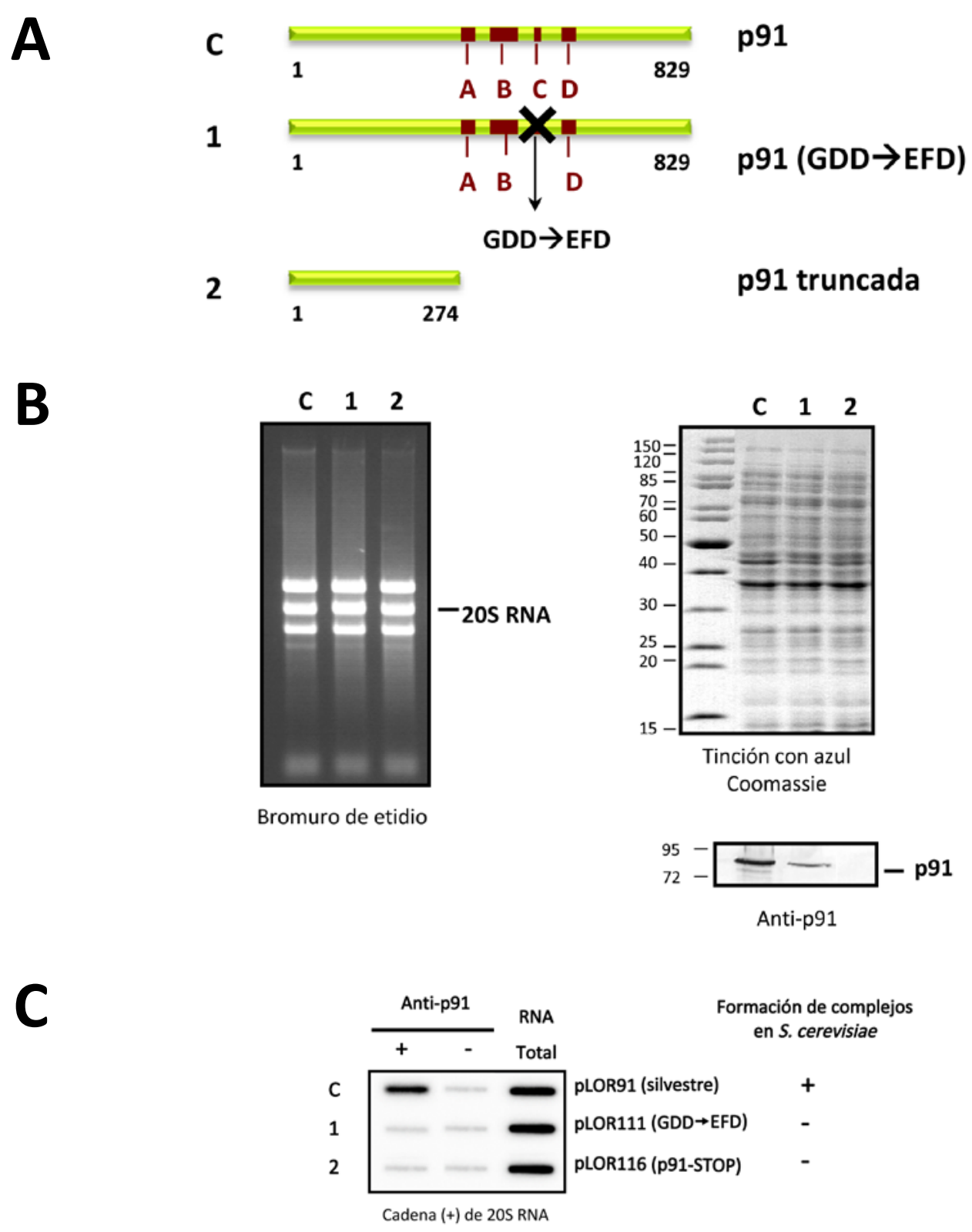

Figura 48. Los complejos p91/20S RNA en E. coli requieren una polierasa funcional. A. Diagrama de la proteína p91 expresada a partir de pLOR91 y de las dos versiones modificadas: 1. La mutación GDD $\rightarrow$ EFD destruye el centro activo, y 2 . Una proteína truncada con 276 aminoácidos del extremo Nterminal. B. Expresión de 20S RNA y cantidad de proteínas totales a partir del lisado de E. coli transformado con los tres plásmidos anteriores. Mediante Western se detecta únicamente p91 y el mutante GDD $\rightarrow$ EFD que tienen el tamaño completo, no así la polimerasa truncada, ya que los anticuerpos sólo detectan el extremo C-terminal de p91. C. 20S RNA aparece en los inmunoprecipitados sólo cuando p91 es silvestre. 
En el extremo $3^{\prime}$ de la secuencia del cDNA se introdujeron tres tipos de cambios: el primero es la modificación C4A (pLOR114). En S. cerevisiae esta modificación afecta a la generación in vivo del virus y a la formación de complejos (Figs. 17 y $25-A$ ). Parece ser que en E. coli, el cambio disminuye un $20 \%$ la formación de complejos p91/20S RNA respecto del control. Además, se intrudujeron dos cambios que modifican la estructura secundaria del extremo 3', el primero abre la base de la estructura (G5C, Fig. 20, pLOR115), y el segundo la altera casi completamente (pLOR121, Fig. 21). En estos dos mutantes aunque la cantidad de 20S RNA y de p91 expresada a partir de los plásmidos modificados en $3^{\prime}$ es prácticamente la misma, las dos mutaciones afectan sustancialmente a la formación de complejos en la bacteria, algo que también ocurre en $S$. cerevisiae (muestras 2 y 3 de la figura 49-C). Por lo tanto, la especificidad en la parte $3^{\prime}$ del RNA es la misma que en S. cerevisiae.

Todos estos datos sugieren que los complejos que se forman en $E$. coli tienen la misma especificidad que los de la levadura, e indican, por tanto, que no se requieren factores de $S$. cerevisiae para su formación, únicamente el RNA y la proteína.

\section{S RNA NO SE REPLICA EN E. coli}

De manera similar a lo realizado en S. cerevisiae, decidimos eliminar el plásmido pLOR91 de la cepa BL21(DE3). Así, si 20S RNA puede mantenerse de forma autónoma en E. coli en ausencia de pLOR91, indicaría que pueden replicarse y generar el virus.

pLOR91 se eliminó de $E$. coli realizando réplicas en medio LB sin antibiótico. Después de pases sucesivos se analizaron el RNA y las proteínas presentes en las células sin plásmido. En la figura 50 se observa que al desaparecer pLOR91, no encontramos ni 20S RNA ni p91 en E. coli, lo que indica que 20S RNA no es capaz de mantenerse de forma autónoma en la célula, al contrario de lo que ocurre en S. cerevisiae. 


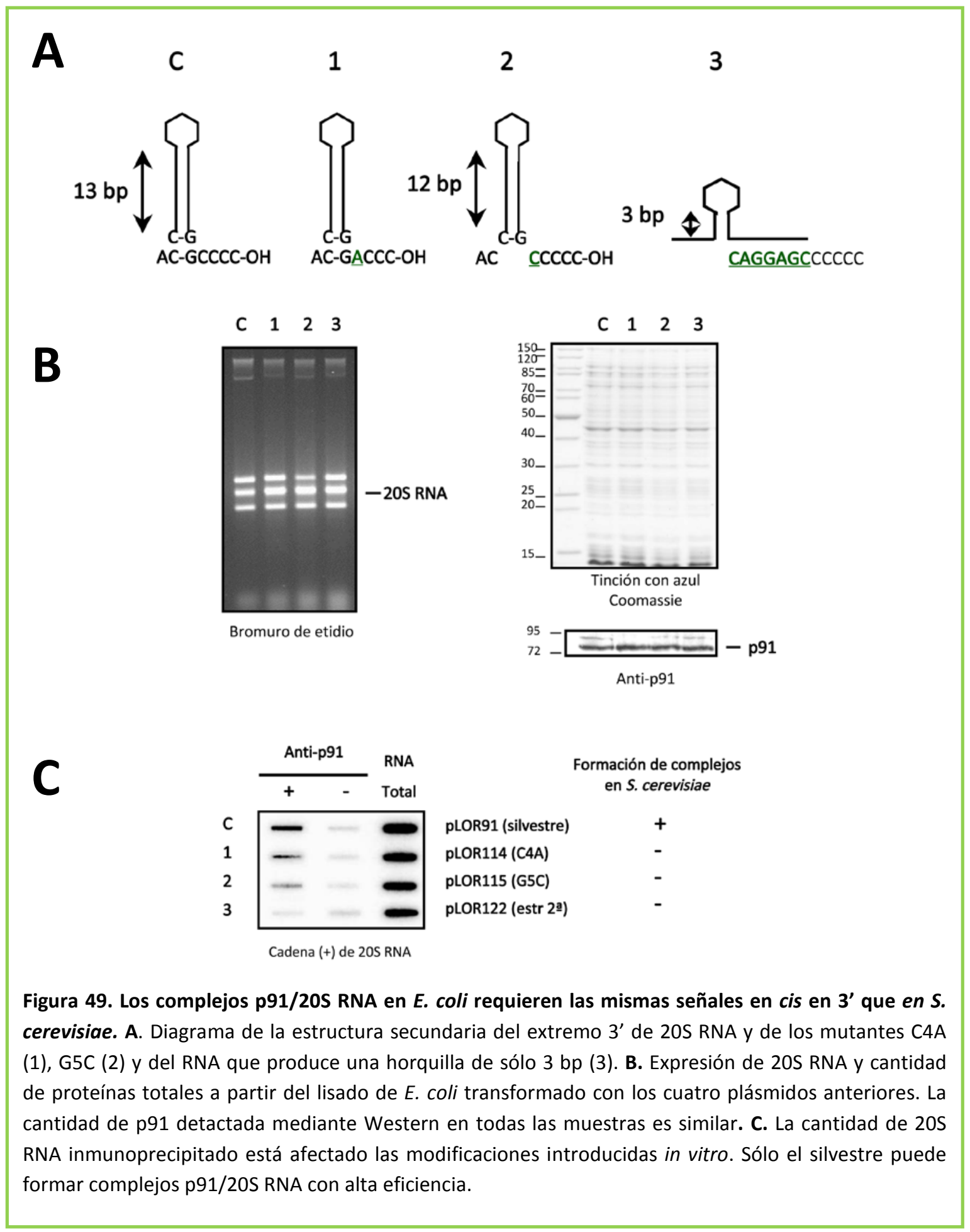

Esto puede ser debido a dos causas:

1. Estos complejos no son activos en replicación

2. Aún siendo activos, puede ser la propia traducción de p91 la responsable, ya que el RNA viral, en ausencia del vector, carece de la secuencia de Shine-Dalgarno (Fig. 44-A) 


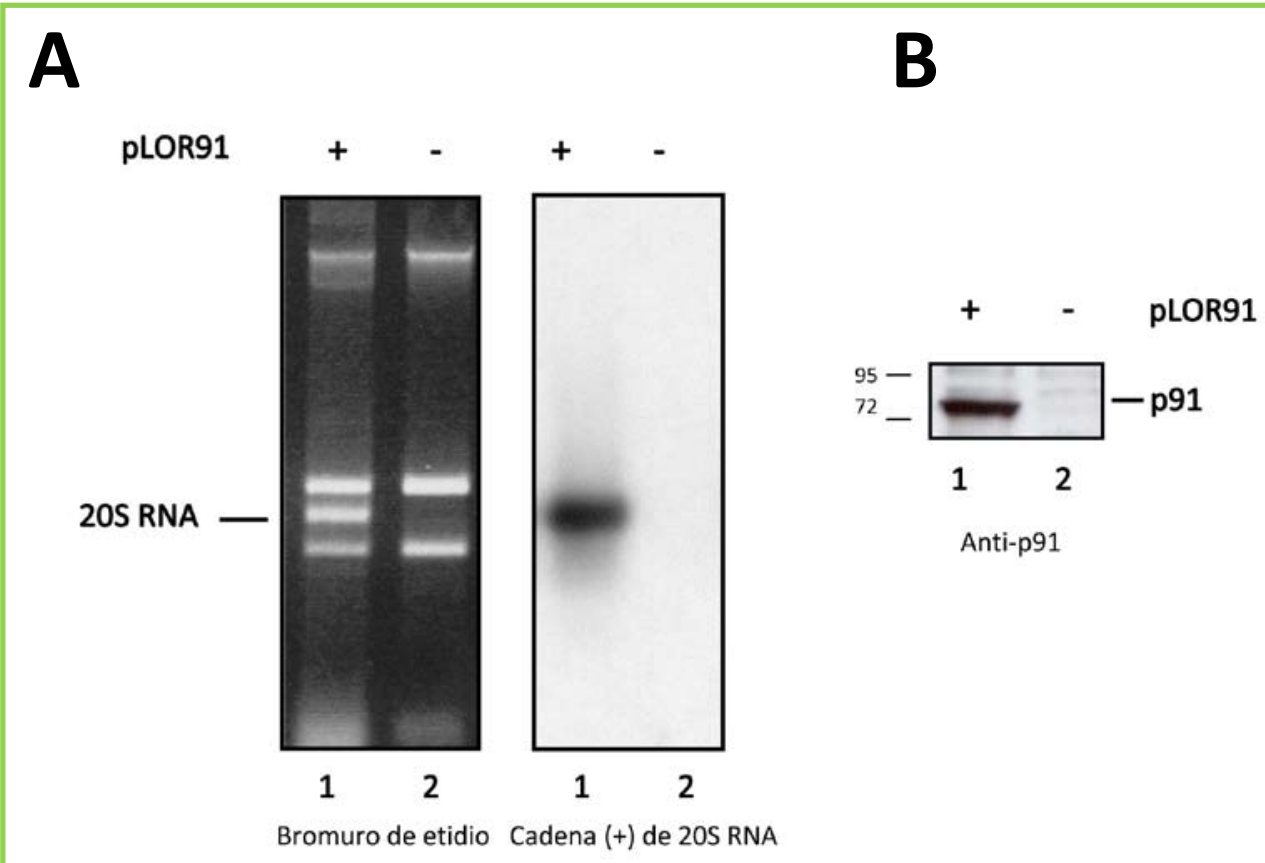

Figura 50. 20S RNA no se mantiene en E. coli de forma autónoma. A. Gel de agarosa teñido con bromuro de etidio en el que se analizan los RNAs de la cepa BL21 transformada con pLOR91 (carril 1), y la misma cepa después de eliminar el plásmido (carril 2). En el panel derecho se muestra el Northern del mismo gel. B. Western de extractos de las muestras analizadas en A con anticuerpos anti-p91.

Dado que se forman complejos entre p91 y 20 SNA en $E$. coli, teníamos interés en determinar si estos eran activos en replicación, ya que se trata de una RNA polimerasa, p91, y su RNA molde, 20S RNA. Para ello utilizamos dos estrategias distintas:

1. Detectar en E. coli las cadenas de polaridad (-), intermediarios en la replicación viral.

2. Comprobar si los complejos p91/20S RNA formados en E. coli se replican in vitro.

1. Para analizar la presencia de cadenas (-) en E. coli transformada con pLOR91 utilizamos una sonda específica de la cadena (-). Además del plásmido estándar, utilizamos como controles negativos algunos de los plásmidos descritos en los apartados anteriores que tenían modificaciones en p91 o en el RNA. En el Northern de la figura 51 se observa hibridación mínima de la sonda con varias especies de RNA, algunas de las cuales se mueven a la altura de 20S RNA y W. Esta señal, sin embargo, parece ser inespecífica ya que también aparece en nuestros controles negativos, cepas transformadas con plásmidos cuya RNA polimerasa no es funcional (es más pequeña o está mutada) y cepas con modificaciones en la estructura secundaria del RNA. Además la cantidad de hipotética cadena (-) detectada es muy pequeña, ya que la exposición de la película ha sido de 50 veces más que la de la cadena (+). 

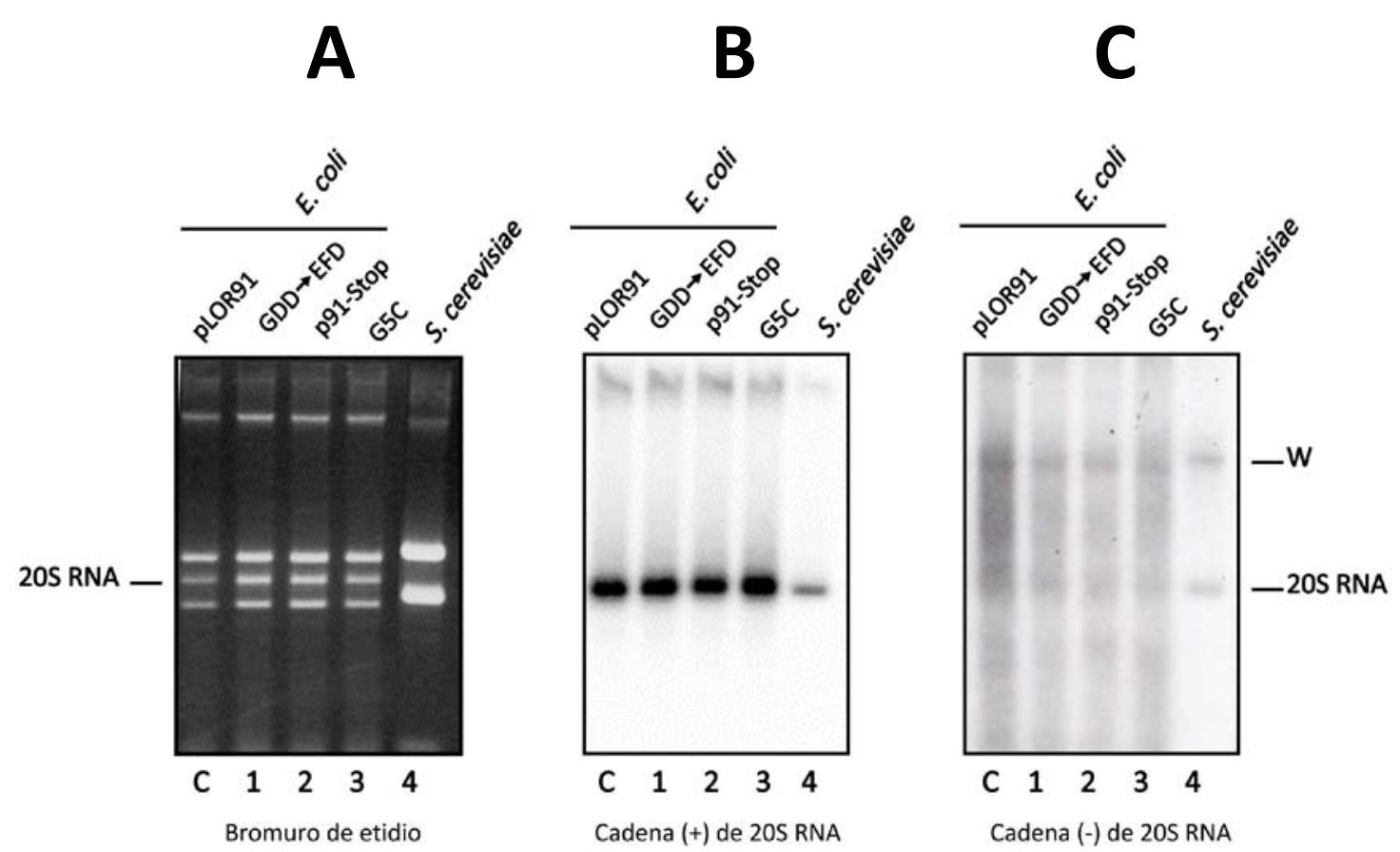

Figura 51. No se detactan cadenas (-) de 20S RNA en E. coli. A. El RNA total de E. coli transformado con pLOR91 se analizó en un gel de agarosa. Como control negativo se utilizó la misma cepa transformada con plásmidos cuyos productos de expresión (20S RNA y p91) no pueden formar complejos. El control positivo es la cepa 924 de S. cerevisiae, que tiene 20S RNA endógeno. B. Northern en el que muestras anteriores se detectan con una sonda específica de la cadena (+) de 20S RNA. C. Northern en el que las mismas muestras se detectan con una sonda específica de la cadena (-). Se indican 20S RNA y W en la muestra de $S$. cerevisiae.

2. El siguiente estudio consistió en valorar la actividad RNA polimerasa in vitro a partir de un lisado de E. coli con complejos p91/20S RNA. Como control positivo se utilizó un lisado de la cepa 924 de S. cerevisiae (Fig. 52-B). En el caso de la levadura se observa la incorporación de radiactividad mayoritariamente en $20 \mathrm{~S}$ RNA, y en menor medida en $\mathrm{W}$ (carril 2 de la parte izquierda). En los lisados en E. coli observamos también incorporación en una banda a la altura de $20 S$ RNA (carril 1), pero esta banda, sin embargo, no es sintetizada por p91, sino por la actividad RNA polimerasa dependiente de DNA presente en el lisado de $E$. coli. En la reacción de replicación in vitro el plásmido pLOR91 que lleva el promotor de la RNA polimerasa del fago T7 está presente, así como la T7 RNA polimerasa expresada in vivo. El producto de la transcripción del plásmido son moléculas de tamaño y secuencia indistinguibles del posible 20S RNA replicado. Para ver si el RNA detectado en E. coli procedía de la actividad RNA polimerasa dependiente de DNA, tratamos las muestras con DNAsa antes de la reacción de replicación (Fig. 52-B, parte derecha). En la autorradiografía ahora no aparece incorporación en 20S RNA de E. coli, lo que indica que la señal observada en el experimento anterior no es producto de replicación viral in vitro, y además 
confirma la idea que teníamos de que los complejos formados en $E$. coli no son activos en replicación.

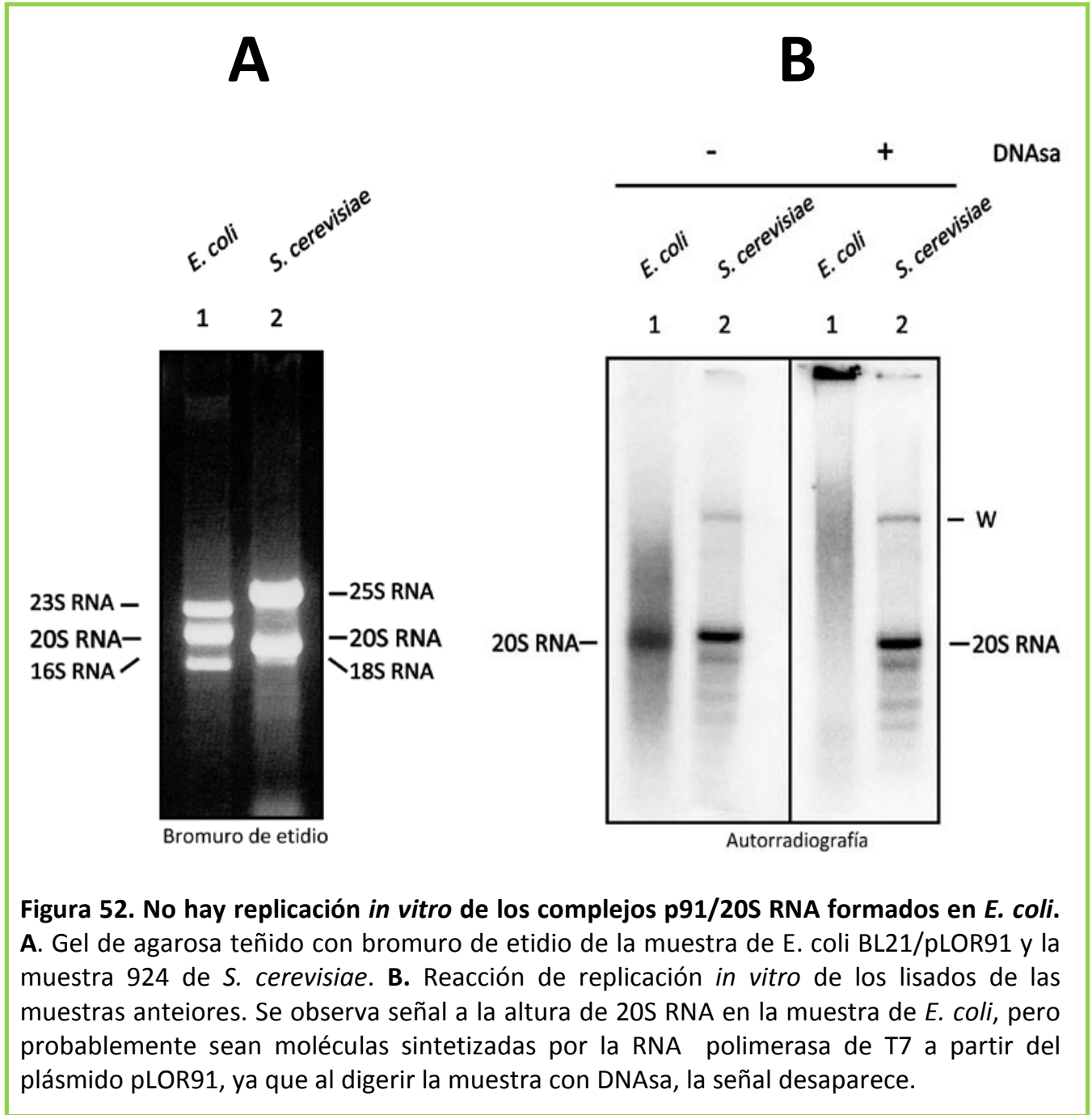

DIFERECIAS EN LA CANTIDAD DE COMPLEJOS p91/20S RNA EN S. cerevisiae Y EN E. coli

Para completar el estudio de los complejos ribonucleoproteicos p91/20S RNA en E. coli, decidimos compararlos con los formados en su hospedador natural, S. cerevisiae. En el año 2000 se demostró que la gran mayoría (sino todo) 20S RNA se encuentra formando complejos con p91 en la célula (Solorzano et al., 2000). Durante la elaboración de este trabajo nos hemos dado cuenta que aunque en $E$. coli se sintetiza una gran cantidad de transcritos de 20S RNA a partir de pLOR91, la cantidad de 20S RNA que detectamos en los inmunoprecipitados es mucho menor, lo que parece indicar que sólo una pequeña parte de los transcritos se encuentran formando complejos con p91. 
Pensamos que la causa de la disminución de complejos en E. coli podía ser la cantidad de p91 expresada, por lo que decidimos cuantificar 20S RNA y p91 expresados en S. cerevisiae y en $E$. coli (Fig. 53-A). A partir del mismo número de células en ambos organismos $\left(3.0 \times 10^{10}\right)$ preparamos lisados y se analizaron mediante Northern y Western la cantidad de 205 RNA y p91 respectivamente, presentes en diferentes volúmenes de los mismos. Se cuantificaron mediante fosforimager y quimioluminiscencia y como se puede observar, a pesar de la enorme cantidad de 20S RNA expresado en E. coli (aproximadamente 7 veces más que en S. cerevisiae), la cantidad de p91 presente es menor que en la levadura (unas 4 veces). Esto indica que aun habiendo síntesis de 20S RNA la eficiencia con la que se traduce la proteína durante el tiempo que dura la inducción con IPTG no es muy elevada. Por otra parte, estos datos sugieren que la diferencia en la cantidad de complejos p91/20S RNA formados en la célula la condiciona la cantidad de p91 disponible. Para ver si esto era así, a partir de los valores obtenidos en la cuantificación del Western ajustamos la cantidad de p91 en las muestras de S. cerevisiae y E. coli y las inmunoprecipitamos con anti-p91 (Fig. 53-C). Tal y como esperábamos, la cantidad de 20S RNA en los inmunoprecipitados en este caso es equivalente. Esto confirma que es la cantidad de p91 la que determina la formación de los complejos con 20S RNA. Calculamos que en E. coli sólo un 3.5\% del RNA expresado se encuentra formando complejos con la polimerasa. Esta baja proporción además de ser debida a la escasa cantidad de p91 presente en la muestra, podría estar afectada por un ineficiente o incorrecto plegamiento en $E$. coli, ya que se trata de un sistema heterólogo en el que eso no se puede controlar.

A pesar de los datos numéricos obtenidos, lo realmente importante de los complejos p91/20S RNA formados en $E$. coli es que estos complejos, independientemente del porcentaje en el que existan, son específicos aun siendo en un hospedador heterólogo. Esto apoya nuestra hipótesis de que en $S$. cerevisiae los complejos se forman sólo con p91 y $20 \mathrm{~S}$ RNA, y no se requieren proteínas del hospedador, al menos en estado de reposo. 


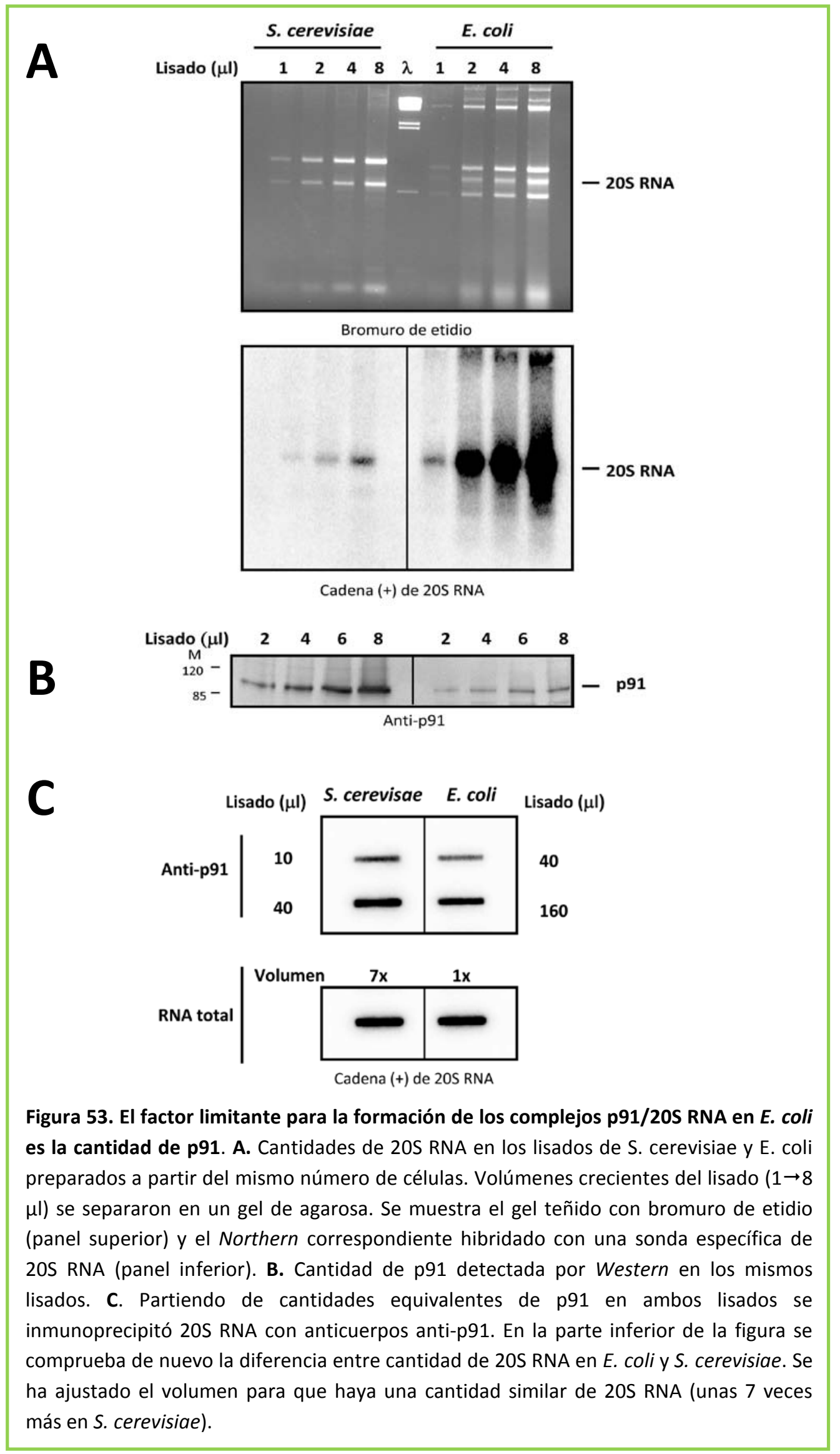




\section{DISCUSIÓN}

"La frase más excitante que se puede oír en ciencia, La que anuncia nuevos descubrimientos, no es iEureka! Sino 'es extraño...'” 


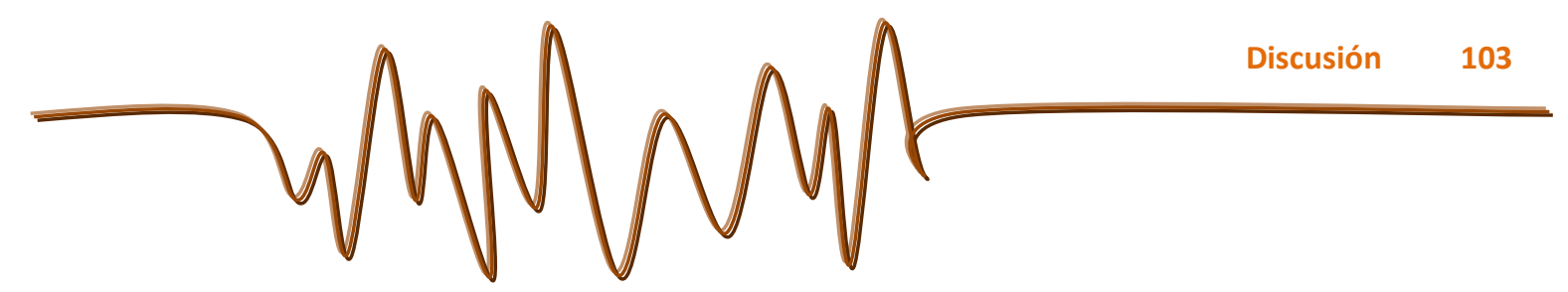

\section{ESTUDIO DE LAS SEÑALES EN cis QUE AFECTAN A LA REPLICACIÓN Y FORMACIÓN DE COMPLEJOS P91/20S RNA}

Los genomas de los virus (+)-ssRNA tienen la capacidad de formar estructuras secundarias y otras de orden mayor, que contribuyen a su estabilidad y participan en interacciones inter- e intramoleculares. Estas señales (o elementos en cis) son muy importantes en el ciclo de vida del virus y sus funciones no pueden ser complementadas en trans. Están involucradas no sólo en la interacción RNA-RNA, sino también en la unión de proteínas virales y celulares al RNA durante los procesos de traducción, replicación del RNA y encapsidación en algunos virus. La mayoría de señales en cis se localizan en los extremos $5^{\prime}$ y 3' altamente estructurados de las regiones no traducidas del genoma (UTR), aunque también pueden estar en la secuencia codificante. Virus humanos como el de la hepatitis A (Picornaviridae), la hepatitis C (Flaviviridae) o el coronavirus humano (Coronaviridae) tienen en sus extremos 5' y 3' señales en cis indispensables para su replicación (Liu et al., 2009).

Los narnavirus 20S RNA y $23 \mathrm{~S}$ RNA tienen genomas ricos en $\mathrm{G}+\mathrm{C}$, lo que facilita la formación de estructuras secundarias en el RNA. Estas estructuras no sólo se forman en los extremos $5^{\prime}$ y $3^{\prime}$, sino que existen a lo largo de todo el genoma. Es, sin embargo, en los extremos donde se localizan algunas de las señales en cis importantes en su replicación y en la formación de complejos con sus RNA polimerasas. A partir de datos de genética reversa con $23 S$ RNA generado con vectores de expresión, se describió la existencia de una señal bipartita próxima a su extremo 3'. Esta estaba formada por las últimas cuatro citosinas y dos purinas desapareadas existentes en el brazo de una estructura secundaria adyacente a las cuatro citosinas (Fig. 53) (Fujimura y Esteban, 2004a).

En este trabajo hemos hecho un estudio similar con 20S RNA, analizando señales en cis próximas al extremo 3'.

Los plásmidos utilizados en estos experimentos son similares a los empleados en la generación de 23S RNA (Esteban y Fujimura, 2003). Así se construyó el vector pRE740, que 
lleva el cDNA completo de 20S RNA detrás del promotor constitutivo del gen PGK1 de $S$. cerevisiae y la ribozima del virus HDV fusionada al extremo 3'.

Los experimentos de generación de narnavirus en S. cerevisiae a partir de vectores de expresión se comenzaron con 23S RNA ya que todas las cepas de las que se disponía en ese momento llevaban 20S RNA. No fue hasta el año 2005 cuando obtuvimos la cepa 2928-4, derivada de la 2928, que había perdido 20S RNA endógeno durante la generación de 23S RNA (Esteban et al., 2005). Esta es la cepa receptora en la mayoría de los experimentos descritos en este trabajo, especialmente en los apartados 1 y 3 de los Resultados. Adicionalmente hemos usado cepas delecionadas procedentes de la colección EUROFAM que derivan de la cepa BY4741, y que carecen de 20S RNA. En ambos fondos genéticos hemos comprobado que la frecuencia de generación de 20S RNA a partir del plásmido pRE740 (y su derivado con marcador seleccionable URA3, pRE763) es muy alta (más del 70\% de las células adquieren el virus y este se mantiene una vez eliminado el plásmido) lo que nos ha permitido analizar las señales en cis necesarias para la replicación de 20S RNA mediante genética reversa.

Tanto pRE740 como pRE763 se han utilizado para generar 20S RNA a partir de las cadenas (+) o genómicas, pero además hemos conseguido generar el virus a partir de las cadenas (-) 0 antigenómicas.

El estudio de las cadenas (-) de 20S RNA se llevó a cabo utilizando un sistema de dos plásmidos, ya que la orientación de esta cadena hace imposible la generación del virus al no poder traducirse el transcrito. En este caso necesitamos un segundo vector que produce una polimerasa en trans que puede unirse a la cadena (-) expresada a partir de otro plásmido, formar complejos y replicar el RNA para generar el virus. A pesar de utilizar dos plásmidos muy parecidos, hemos observado que no hay recombinación entre los transcritos expresados a partir de ellos en base a varios criterios: 1) cada plásmido lleva 20S RNA clonado en sentido contrario. 2) Al modificar la zona GDD del plásmido que produce la polimerasa, no se produce el virus a pesar de que esa secuencia está intacta en el segundo vector. 3) Si se cambia la secuencia de corte de la ribozima GGG $\rightarrow$ AAA en el plásmido molde, no se puede generar 20 S RNA. La eficiencia en la generación de 20S RNA es muy alta, similar a cuando se usa un plásmido, y además hemos comprobado que efectivamente, los virus generados proceden de la cadena (-), ya que esta contiene un sitio Smal que le diferencia de las cadenas (+) generadas a partir del plásmido de la polimerasa. Por lo tanto, este sistema también ha permitido hacer genética reversa para estudiar las señales en cis de la cadena antigenómica. 
En este trabajo hemos demostrado la existencia de señales en cis en el extremo 3' de las cadenas (+) y (-) del virus. En paralelo, hemos visto que tal y como ocurre en $23 \mathrm{~S}$ RNA, las señales importantes en replicación también lo son para la formación de los complejos ribonucleproteicos. Tanto la cadena (+) como la (-) tienen en su extremo $3^{\prime}$ una estructura secundaria en forma de horquilla seguida de cuatro citosinas desapareadas que consituyen el final de la molécula de RNA (Fig. 53). En ambos casos la tercera y cuarta citosinas son esenciales para la replicación viral, ya que su modificación a adenina impide la generación de 20S RNA. Sin embargo, al modificar o eliminar los últimos dos nucleótidos, o al añadir bases en el extremo $3^{\prime}$, los virus generados siempre tienen cuatro citosinas en la secuencia terminal (...CCCC-OH). Esto indica que aunque la primera y segunda no sean esenciales para la generación, es necesario que el extremo finalice con cuatro citosinas. Además también indica que existe un mecanismo capaz de corregir las modificaciones introducidas in vitro en el extremo 3' para que siempre termine en cuatro Cs.

\section{CADENA (+) CADENA(-)}

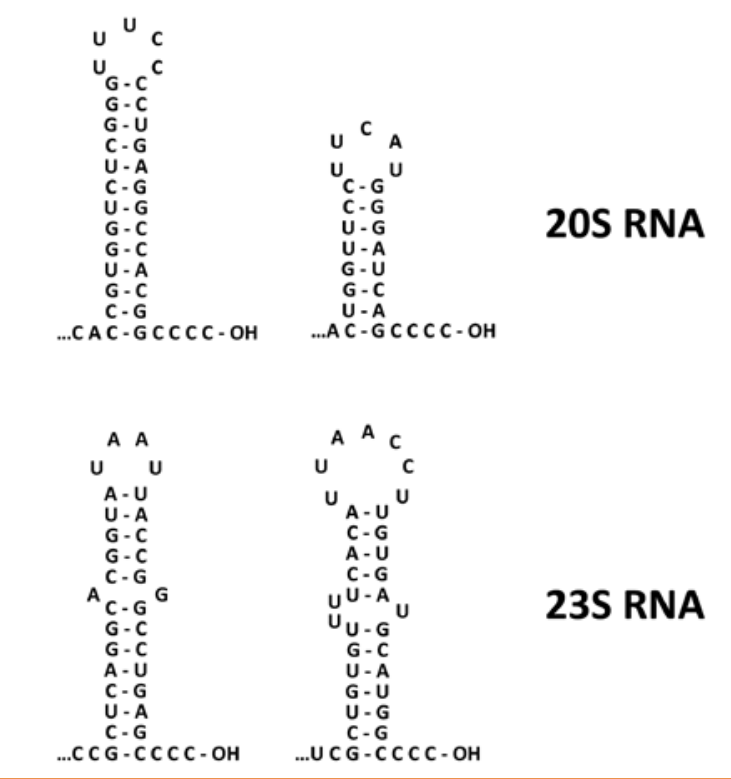

Figura 53. Predicción de la estructura secundaria de los extremos 3' de las cadenas (+) y (-) de los narnavirus 20S RNA y 23S RNA. En todos los casos son estructuras en horquilla que terminan en GCCCC-OH. En rojo se señalan las señales en cis presentes en las cuatro estructuras.

La estructura secundaria en horquilla adyacente al extremo 3' también es importante en la replicación de 20S RNA, ya que hemos comprobado que los cambios que modifican la longitud del brazo hacen inviable la generación del virus. Esto indica que la secuencia primaria del brazo no es importante, y tampoco parece serlo la del bucle, pero sí lo es la existencia del brazo en la horquilla. En el caso de la cadena (+) también hemos analizado parcialmente la segunda estructura secundaria adyacente (nt. 38 - 91), más compleja todavía. Aunque los cambios estudiados no han sido numerosos, ninguno de ellos afecta a la 
generación de 20S RNA, y por tanto, esta estructura no parece ser importante en la replicación del virus.

Recientemente se ha demostrado en nuestro laboratorio que la unión de p91 a $20 \mathrm{~S}$ RNA tiene lugar en los extremos $5^{\prime}$ y $3^{\prime}$ de la molécula y en menor medida en la zona central. En este trabajo hemos confirmado que la polimerasa in vivo se une al extremo 3', ya que cambios en ciertas zonas de la secuencia y la estructura secundaria afectan a la formación de complejos. También sabemos que el lugar de unión en $5^{\prime}$ tiene lugar en la segunda estructura secundaria adyacente al extremo 5' (nucleótidos 72 - 104), que además también tiene señales en cis para la replicación del virus (Fujimura y Esteban, 2007).

Esta correlación entre replicación y formación de complejos también se observa en el virus 23S RNA (Fujimura y Esteban, 2004a). Creemos que la formación de los complejos estabiliza el genoma viral y lo proteje de los mecanismos de degradación de mRNAs del hospedador. Ya que 20S RNA carece de cápsida, no tiene cola de poli(A) y probablemente sin cap es un buena diana para los sistemas de degradación, por lo que su protección mediante la unión a p91 es esencial para su supervivencia. Todos aquellos cambios que pongan en peligro la estabilidad del complejo se traducen como ausencia de generación del virus a partir de nuestros vectores de expresión.

\section{REPARACIÓN DE LOS EXTREMOS 3' EN LAS CADENAS (+) Y (-) DE 20S RNA}

Los virus con genomas lineales deben desarrollar mecanismos para poder reparar sus extremos 3', ya que durante la replicación el RNA está expuesto a la degradación por nucleasas. Debido a que su replicación comienza en el extremo 3', existen muchas posibilidades de que existan mecanismos de protección y reparación de sus extremos.

En este trabajo hemos realizado experimentos en los que hemos modificado los extremos $3^{\prime}$ de las cadenas (+) y (-) de 20S RNA en el vector de expresión bien añadiendo bases extra, bien eliminando o modificando las últimas citosinas de la secuencia.

La adición de bases en el extremo 3' de la secuencia (delante de la ribozima) no afecta a la generación de 20S RNA y esas bases adicionales se eliminan durante este proceso. Dado que el genoma viral es una molécula de RNA monocatenario sin poliadenilar, la actividad responsable de la eliminación de estos nucleótidos podría ser la llevada a cabo por el complejo multiproteico del exosoma, que degradaría la molécula en dirección $3^{\prime} \rightarrow 5^{\prime}$ hasta llegar hasta las cuatro Cs del extremo, que aunque sean monocatenarias, probablemente 
estén protegidas por p91. Datos obtenidos en el laboratorio indican que si se aumenta el tamaño de la secuencia extra entre el extremo 3 ' viral y el sitio de corte de la ribozima, se disminuye enormemente la eficiencia de generación de 20S RNA, ya que el exosoma elimina los nucleótidos uno a uno (Esteban R., resultados sin publicar).

Por otra parte, el mecanismo responsable de la reparación de las bases modificadas (C1A, C2A) o eliminadas en el extremo 3' de 20S RNA también es desconocido, aunque existen varias posibilidades que se resumen a continuación:

a) Formación de estructura en panhandle (mango de sartén): Se podría formar debido a las repeticiones invertidas de los extremos $5^{\prime}$ y $3^{\prime}$ de la secuencia. Deleciones o modificaciones en $3^{\prime}$ podrían ser reparadas usando la secuencia del extremo 5' como molde, como ocurre en uno de los sistemas de reparación del Virus Dengue (DEV) (You y Padmanabhan, 1999). Pero este no parece ser el caso, porque se ha visto que modificaciones simultaneas en los extremos 3' y 5' de 23 S RNA se corrigen (Fujimura y Esteban, 2004a). Suponemos que en el caso de 20S RNA ocurre algo similar.

b) Maquinaria de la RNA polimerasa: Las RdRp introducen a menudo errores que pueden reparar. Si faltan nucleótidos en el extremo 3', se añaden las bases correctas en las nuevas cadenas nacientes durante la replicación. En el caso del virus dengue tipo 2 (DEV-2), es la actividad nucleotidil transferasa de la RdRp la que añade los nucleótidos eliminados en el extremo $3^{\prime}$ sin molde (Teramoto et al., 2008). En algunos virus, como en el TCV (Turnip crinkle carmovirus) se ha descrito que se pueden reparar deleciones de hasta 6 nt del extremo 3' utilizando oligonucleótidos de $4-8$ nt producidos por la síntesis abortiva de la replicasa viral usando el extremo 3' del RNA genómico como molde (Nagy et al., 1997; Guan y Simon, 2000). Esto no puede ocurrir durante la generación de 20S RNA a partir de vectores, ya que en la célula no hay moléculas con la secuencia completa que sirvan como molde para la síntesis del extremo 3' adecuado. Una vez generado el virus, o en 20S RNA endógeno podría ocurrir este mecanismo, pero esto es algo que desconocemos.

c) Factores del hospedador: En muchos virus, como en los narnavirus, la estructura secundaria de su extremo 3' se parece bastante al Top half domain de los tRNA (Mans et al., 1991; Fujimura y Esteban, 2004a). El brazo aceptor y el brazo T forman una estructura muy parecida a la estructura secundaria del extremo 3' de 20S RNA; esta consiste en un brazo de 12- 13 bp y el bucle TUC de 7 nt (Fig.54). Estos RNAs virales podrían ser, por tanto, aminoacetilados y funcionar como sustrato de la tRNA nucleotidil transferasa (CCA-Adding 
enzyme) que puede añadir las bases CCA en el extremo $3^{\prime}$ de la secuencia del tRNA. Esta enzima usa CTP y ATP para reparar el extremo 3' de los tRNAs o estructuras similares catalizando la adición de los nt CCA independientemente del molde (Cho et al., 2002). Se cree que esta enzima podría estar implicada en la reparación del extremo 3' del Virus del mosaico del Bromo (BMV, Brome Mosaic Virus) (Hema et al., 2005). Existen algunas evidencias que sugieren que este podría ser el mecanismo que tiene lugar en la reparación del extremo 3' de 20S RNA:

- Un $20-30 \%$ de las moléculas analizadas (tanto cadenas (+) como (-)) tienen una A en su extremo 3' (...CCCC(A)-OH) (Rodríguez-Cousiño y Esteban, 1992; Rodríguez-Cousiño et al., 1998) lo que también ocurre en 235 RNA (Esteban, 1993).

- La estructura secundaria del extremo 3' de ambas cadenas se parece mucho al top half domain del tRNA (tRNA like sequence, TLS). Estas estructuras aumentan la estabilidad del RNA y favorecen el inicio de la síntesis de la cadena (-) entre otras funciones (Hema et al., 2005). Estas estructuras son reconocidas por enzimas tales como las aminoacil tRNAs sintetasas (Shi et al., 1992; Schimmel y Ribas de Pouplana, 1995). El nucleótido aceptor del grupo CCA no debe estar apareado, como es el caso del extremo $3^{\prime}$ de 205 RNA. En nuestro caso correspondería a la tercera citosina del extremo 3', lo que podría explicar por qué esa base es esencial en la replicación de 20S RNA y no puede ser delecionada.

\section{EXTREMOS 3' DE 2OS RNA}

CADENA (+)

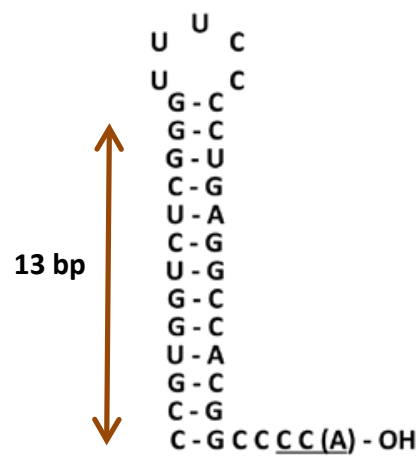

CADENA (-)

\section{tRNA $^{\text {Tyr }}$}

C ${ }^{R} A$

U N Bucle TWC

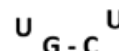

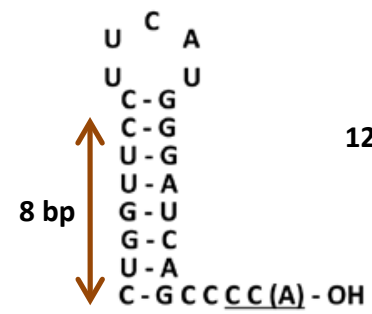

Figura 54. Comparación de las estructuras secundarias de las cadenas $(+)$ y (-) de 20S RNA con el top half domain de un tRNA ${ }^{\text {Tyr }}$. Los tres RNAs tienen una estructura secundaria similar, lo que sugiere que el extremo 3' de 20 SNA podría ser sustrato de la CCA-adding enzyme de S. cerevisiae. La (A) indicada en las estructuras de 20S RNA corresponde a la adenina añadida postranscripcionalmente encontrada en alrededor de un $20 \%$ de la población. El Top Half Domain del tRNA ${ }^{\mathrm{Tyr}}$ eucariótico procede de (Sprinzl et al., 1989). Y, R y N corresponden a pirimidina, purina y cualquier base respectivamente. 


\section{EFECTO DE LA EXONUCLEASA XRN1/SKI1 SOBRE LA GENERACIÓN Y EL MANTENIMIENTO DE 20S RNA}

Durante el ciclo de vida de un virus se requieren tanto factores virales como del hospedador. En los virus ss-(+)RNA hay proteínas del hospedador participando en la replicación del genoma viral y su traducción (chaperonas, helicasas de RNA, factores de decapping...). El papel y función de cada factor es diferente dependiendo del virus, pero en todos los casos el objetivo del virus es su supervivencia. Aunque todavía quedan muchos datos por esclarecer en la replicación y traducción de 20S RNA, suponemos que tiene que haber una cooperación involuntaria de S. cerevisiae que permita la propagación del virus.

Por otra parte, teniendo en cuenta que 20S RNA se localiza en el citoplasma y su genoma no está encapsidado en viriones, podría ser sensible a la degradación por exonucleasas celulares. Una de las estrategias de supervivencia viral podría consistir en evadir las nucleasas implicadas en los mecanismos de vigilancia celular. Los virus pertenecientes al otro género de la familia Narnaviridae, los mitovirus, se localizan en las mitocondrias de su hospedador. Esta diferencia implica que su genoma se ha tenido que adaptar a otro entorno, utilizando el código genético mitocondrial para traducir su RdRp (Cole et al., 2000). Asímismo, puede haber desarrollado estrategias para protegerse de las nucleasas mitocondriales como Pet127 (Fekete et al., 2008). Sus genomas son ricos en $A+U, a$ diferencia de los narnavirus, y no hay datos sobre la formación de estructuras secundarias que le puedan proteger. Tampoco se sabe cómo llegaron a las mitocondrias de su hospedador.

\section{EFECTO DE XRN1/SKI1 EN LA GENERACIÓN DE 20S RNA}

En este trabajo hemos demostrado que la generación eficiente de $20 \mathrm{~S}$ RNA en $S$. cerevisiae a partir de vectores depende del gen XRN1/SKI1. La exonucleasa Xrn1p es la principal RNAsa citoplasmática de esta levadura, encargada de la degradación de los mRNAs en dirección 5' $\rightarrow 3^{\prime}$ (Larimer et al., 1992). Nuestros datos indican que Xrn1p es la enzima responsable de la eliminación de los 47 nucleótidos de secuencia no viral presente en el extremo 5' de los transcritos generados a partir del vector pRE740 (o de sus derivados) en base a varias observaciones. 1) En primer lugar, a medida que disminuye la longitud de la secuencia no viral en $5^{\prime}$ aumenta la eficiencia en la generación del virus. 2) Además, al 
expresar el gen $X R N 1$ a partir de un plásmido centromérico en la cepa $X R N 1 \Delta, 20 S$ RNA se genera con la misma eficiencia que en la cepa silestre. 3) Por último, si en el experimento anterior se modifican dos aminoácidos necesarios para la actividad exonucleasa (D206A, D208A), el virus de nuevo tiene muchos problemas para generarse, lo que indica que realmente es esta actividad la responsable de eliminar la secuencia de $47 \mathrm{nt}$ procedente del vector. Esto además sugiere que la secuencia no viral en 5' procedente del vector debe ser eliminada para generar el virus, ya que el transcrito a pesar de tener la secuencia completa de 205 RNA no sirve de molde. Todo esto indica que en el extremo 5' del genoma viral existen señales en cis importantes en replicación, por lo que las cuatro guaninas en dicho extremo no pueden funcionar como promotores cuando se encuentran internamente en la molécula.

A pesar de la baja eficiencia con la que 20S RNA se genera en una cepa XRN1L, finalmente se consiguen cepas $X R N 1 \Delta$ con el virus generado a partir de vectores. En este caso, probablemente la eliminación de secuencia no viral en el extremo $5^{\prime}$ se deba a la actividad citoplasmática residual de la exonucleasa $5^{\prime} \rightarrow 3^{\prime}$ nuclear, Rat1p (Johnson, 1997). En las mitocondrias de $S$. cerevisiae existe otra exonucleasa $5^{\prime} \rightarrow 3^{\prime}$ Pet $127 p$, responsable del procesamiento del mRNA (mitochondrial RNA), pero no se ha visto que pueda sustituir funcionalmente a Xrn1p (Fekete et al., 2008).

Como Xrn1p actúa sobre RNAs con extremo 5' monofosfato originados después de haber perdido el grupo cap durante el decapping de los mensajeros, es lógico pensar que factores que participan en este paso previo tengan también efecto sobre la generación de 20S RNA. Para comprobar si hay otros factores de $S$. cerevisiae que puedan afectar a la generación de 20 SNA, se ha generado el virus en mutantes relacionados con decapping de mRNAs. Se ha comprobado que la ausencia de alguno de los factores del complejo Lsm1p7p/Pat1p (Lsm1p, Lsm6p, Lsm7p y Pat1p) no afecta a la generación del virus, así como el potenciador de decapping Edc1p. Sólo se ha encontrado que en el mutante $D H H 1 \Delta$, que codifica una helicasa de RNA, no se puede generar 20S RNA, independientemente de la secuencia no viral en el extremo 5', pero no tiene problemas en mantenerlo cuando se introduce en la célula por citodución. Esto indica que $D H H 1$ no se requiere para la replicación de 20 S RNA pero probablemente sea necesario para procesar el transcrito primario a partir del vector (Esteban et al., 2008). 


\section{EFECTO ANTIVIRAL DE LOS GENES SKI}

Los genes SKI se describieron inicialmente como genes cuyas mutaciones producían un incremento de la cantidad de toxina killer en S. cerevisiae, lo que hacía que estas cepas fueran superkiller frente a otras killer (Ridley et al., 1984). En la cepa $X R N 1 \Delta / S K I 1 \Delta$, el número de copias de algunos virus killer aumenta espectacularmente, como es el caso del virus L-A (incremento de 5-10 veces respecto a la cepa silvestre) (Esteban et al., 2008). En otros sistemas de virus heterólogos como el TBSV (Tomato bushy stunt virus), al expresar su genoma en una cepa XRN1 $\Delta$ de $S$. cerevisiae el número de copias de su genoma aumenta 1050 veces (Serviene et al., 2006). Estos datos sugieren que el gen $X R N 1 / S K I 1$ es el responsable del control del número de copias de algunos virus, es decir, ejerce un efecto antiviral. Nuestros datos muestran que la sobreexpresión de la exonucleasa Xrn1p/Ski1p da lugar a la eliminación del virus L-A en la célula con una alta frecuencia, algo que no ocurre si el dominio exonucleasa está modificado. El número de copias del virus 20S RNA, sin embargo, no se ve afectado por Xrn1p. Sin embargo, cuando está sobreexpresada disminuye ligeramente la cantidad de 20S RNA, aunque no consigue eliminar el virus.

El genoma de L-A es bicatenario y está encapsidado en viriones, pero creemos que los intermediarios de replicación, los transcritos de polaridad positiva que salen al citoplasma para traducirse y encapsidarse en nuevos viriones, pueden ser degradados en el citoplasma de S. cerevisiae en dirección $5^{\prime} \rightarrow 3^{\prime}$ por Xrn1p. Estas moléculas, así como el genoma de $20 \mathrm{~S}$ RNA podrían ser diana de la exonucleasa, aunque como he mencionado anteriormente el mantenimiento de 20S RNA no se ve afectado, sólo su generación. La razón por la que $20 \mathrm{~S}$ RNA es resistente a la acción de la exonucleasa, incluso cuando está sobreexpesada en la célula, parece que reside en la estructura secundaria de su extremo 5' (Fig. 36). La secuencia del genoma de 20S RNA comienza con cuatro guaninas. Este nucleótido es muy resistente a la exonucleasa Xrn1p (Decker y Parker, 1993; Stevens, 2001). Además, el extremo se encuentra formando parte de una fuerte estructura secundaria en forma de horquilla. La combinación de estos dos elementos, confieren al genoma de 20S RNA una gran protección frente a la digestión exonucleolítica de Xrn1p.

De igual manera, la sensibilidad del virus L-A a la actividad de Xrn1p puede ser consecuencia de su secuencia primaria y de la ausencia de una estructura secundaria fuerte similar a la de 20 S RNA en el extremo 5' de su genoma. La cadena (+) comienza con una zona muy rica en $\mathrm{A}+\mathrm{U}$ (más sensible a exonucleasas) que unido a la ausencia de una estructura secundaria, hace L-A sea más susceptible a la acción de Xrn1p. Experimentos en nuestro 
laboratorio con Xrn1p purificada, confirman que, de hecho, la cadena (+) de L-A es sensible a su digestión, mientras que 20S RNA no (Fujimura, T., resultados sin publicar).

Respecto a otros genes SKI, se ha visto cómo el número de copias de 20S RNA aumenta en ausencia de los genes del complejo SKI (SKI2, SKI3 o SKI8), SKI7 (Fig. 37) u otros componentes del exosoma como SKI4 (Matsumoto et al., 1990; Esteban R., datos sin publicar). Estos genes, además de estar implicados en la degradación de mRNAs en dirección $3^{\prime} \rightarrow 5^{\prime}$ por el exosoma, se ha descrito que suprimen la expresión de RNAs que carecen de cola de poli(A), algo común en RNAs virales (Widner y Wickner, 1993; Masison et al., 1995; Searfoss y Wickner, 2000). En la actualidad, no sabemos cómo su ausencia afecta al número de copias del genoma de 20S RNA, pero datos en nuestro laboratorio con 23S RNA sugieren que la degradación principal del RNA viral ocurre en sentido $3^{\prime} \rightarrow 5^{\prime}$ (Ramírez-Garrastacho, M., datos sin publicar).

\section{LOS COMPLEJOS RIBONUCLEOPROTEICOS P91/20S RNA EN REPOSO NO NECESITAN FACTORES DEL HOSPEDADOR}

Los complejos p91/20S RNA son clave para entender la replicación del virus 20S RNA en S. cerevisiae. Consideramos entidad viral al complejo ribonucleoproteico formado por la RdRp p91 y el genoma viral, 20S RNA. Por ello estamos interesados en caracterizarlos mejor. Los trabajos previos realizados en nuestro laboratorio nos han permitido conocer algunas de sus propiedades, desde su detección y especificidad de la unión (García-Cuéllar et al., 1995), hasta determinar qué zonas del RNA son a las que se une p91 (Fujimura y Esteban, 2007). También sabemos que todo el 20S RNA presente en la célula se encuentra formando complejos y la estequiometria del RNA y la proteína (Solórzano et al., 2000). Todas estas características podrían estar relacionadas con el hecho de que el virus 20S RNA carezca de cápsida o virión que proteja su genoma de las exonucleasas celulares, abundantes en el citoplasma. En este sentido, es posible que p91 actúe como una pseudocápsida que protege al RNA, lo que explicaría que la unión tenga lugar principalmente en los dos extremos del genoma, protegiéndolos. Esta protección del RNA en 5' y 3' no sólo depende de esta unión, ya que como hemos visto en este trabajo, las estructuras secundarias que forma el genoma 
del virus ofrecen una defensa fuerte frente a los sistemas de degradación de mRNAs en $S$. cerevisiae.

En cualquier caso, cuando nos referimos a los complejos p91/20S RNA es importante comprender el estado metabólico en el que se encuentran. Si bien todas las consideraciones anteriores están hechas sobre los complejos que denominamos "estáticos" o "en reposo", es evidente que existen complejos dinámicos, que se están replicando activamente para dar lugar a las cadenas (-) a partir de las cadenas (+) y viceversa (Fig. 5, ciclo replicación virus). Estos complejos y sus intermediarios de replicación han sido estudiados en detalle en nuestro grupo, e incluso se ha propuesto un posible mecanismo de replicación viral (Fujimura et al., 2005; Esteban, 2006). Según esta hipótesis podría haber hasta dos moléculas de p91 formando parte de los complejos activos en replicación: una polimerasa unida al molde y la que lo está replicando. Al acabar la síntesis tanto el molde como el producto se liberan unidos a una proteína de nuevo en forma de complejos con una estequiometría RNA:proteína de 1:1.

Durante los momentos en los que los complejos son activos en replicación, así como durante la traducción de p91, es necesario que participen factores de S. cerevisiae. Dado que estos complejos dinámicos son muy difíciles de analizar, decidimos averiguar qué ocurre en los complejos en reposo. De ellos sabemos la estequiometría del RNA y la polimerasa del complejo, pero no si existe alguna proteína del hospedador necesaria para su formación o estabilización.

Para responder a esta pregunta, en este trabajo se han seguimos tres aproximaciones experimentales:

1. Intento de purificación de los complejos p91/20S RNA

2. Caracterización de las posibles proteínas unidas al complejo utilizando anticuerpos anti-p91

3. Análisis de proteínas unidas a complejos formados con p91 fusionada a la GFP y 20S RNA. En este caso los anticuerpos utilizados fueron anti-GFP

Para purificar los complejos p91/20S RNA utilizamos una metodología clásica de purificación de proteínas basada en el coeficiente de sedimentación de los mismos: centrifugaciones diferenciales seguidas de gradientes de glicerol. Incluso intentamos enriquecer posteriormente las fracciones del gradiente que contenían los complejos en geles 
de agarosa nativos (no se mostró el resultado por problemas de degradación del RNA de la muestra). De esta forma, a pesar de enriquecer los complejos p91/20S RNA de la muestra alrededor de 300 veces, siempre había un número variable de proteínas de $S$. cerevisiae cosedimentando con los ellos. Estas proteínas, sin embargo, parecen ser inespecíficas, ya que se encuentran en las mismas fracciones del gradiente en una cepa isogénica sin el virus. Una de las más abundantes es la chaperona Hsp26p, que forma agregados de aproximadamente 600 kDa. Aunque esta proteína cosedimenta con 20S RNA, sin embargo no está relacionada con el virus (Widner et al., 1991).

Para tratar de eliminar la mayor parte de proteínas inespecíficas de la fracción e intentar caracterizar las posibles proteínas unidas a los complejos, los inmunoprecipitamos con anticuerpos anti-p91 y analizamos las proteínas presentes mediante tinción con plata. Esta técnica nos dio datos poco fiables debido a la presencia de IgG en las muestras. Por ello se realizó un marcaje in vivo con ${ }^{35} \mathrm{~S}$ y se analizaron las proteínas que acompañan a p91 en el inmunoprecipitado. Con esta técnica, mucho más resolutiva, comprobamos que las pocas proteínas que aparecen coinmunoprecipitando con p91 y $20 \mathrm{~S}$ RNA también son inespecíficas, ya que aparecen en la cepa control que no tiene 20S RNA.

Obtuvimos un resultado similar utilizando anticuerpos anti-GFP, aprovechando que in vivo también se pueden formar complejos entre el RNA y la proteína de fusión p91-GFP expresada a partir de vectores. La metodología es diferente y a pesar de que el resultado obtenido fue menos limpio que en el caso anterior, las proteínas que acompañan a los complejos parecen ser de nuevo inespecíficas.

Todos los datos sugerían que en la formación de complejos en reposo sólo participan p91 y 20 S RNA, sin necesidad de otras proteínas de S. cerevisiae. Por lo tanto, cabría esperar que también se pudieran formar complejos en un organismo heterólogo en el que se exprese el RNA y la proteína. Si se forman en otro sistema, es que realmente no intervienen proteínas de S. cerevisiae para su formación.

\section{EXPRESIÓN DE 20S RNA EN UN SISTEMA HETERÓLOGO: E. coli}

El uso de organismos heterólogos para la expresión de virus es algo habitual como lo demuestran los trabajos de P. Ahlquist en los que estudia la replicación del virus del mosaico del bromo (BMV, Brome Mosaic Virus) en S. cerevisiae (Janda y Ahlquist, 1993; Noueiry y Ahlquist, 2003) o los de P. Nagy con el virus ramificado del tomate enano (Tomato Bushy Stunt Virus) (Panavas y Nagy, 2003; Pogany y Nagy, 2008). La expresión de parte de los 
componentes virales en S. cerevisiae ha permitido establecer un modelo de replicación para estos virus e identificar algunos factores de la levadura necesarios en su replicación.

La formación de complejos p91/20S RNA en E. coli requiere la correcta expresión de 20S RNA y p91 a partir de plásmidos; para la traducción de p91 la secuencia de ShineDalgarno en la parte $5^{\prime}$ de transcrito es esencial. Observamos que tanto el RNA como la proteína cosedimentaban en gradientes de glicerol de igual maneral que lo hacen los de S.cerevisiae. Este dato sugiere que ambas moléculas están asociadas en $E$. coli, lo que confirmamos inmunoprecipitando los complejos con anti-p91. A pesar de que la cantidad de 20S RNA expresada en E. coli a partir de la T7 RNA polimerasa es muy superior a la que existe normalmente en S. cerevisiae, la cantidad de complejos formados con p91 es muy inferior (sólo un 4\% del 20S RNA expresado en $E$. coli está formando complejos) debido a que sólo un bajo porcentaje de p91 parece traducirse en nuestras condiciones experimentales. Por lo tanto, la poca cantidad de proteína expresada limita el número de complejos que se pueden formar. No sabemos si la escasa cantidad de polimerasa se debe a un problema en la traducción del RNA o a que las proteínas expresadas tienen problemas en su plegamiento, lo que implicaría que no se unieran correctamente al RNA. En cualquier caso, estos complejos formados en $E$. coli son específicos, ya que mutaciones en la polimerasa y el RNA afectan a su formación de igual manera que en S. cerevisiae.

Ya que p91 es una RdRp y 20S RNA su molde, ¿Se replican los complejos en E. coli? ¿Podría llegar a generarse el virus a partir de vectores de forma similar a lo que ocurre en $S$. cerevisiae? Los datos experimentales presentados en este trabajo indican que no es así, debido a tres observaciones:

1. Al eliminar el plásmido de las células de E. coli no hay 20 SNA ni p91.

2. No parecen existir las cadenas (-), intermediarios en la replicación de 20S RNA.

3. Consistente con el dato anterior, complejos enriquecidos procedentes de E. coli no son activos en replicación in vitro, en condiciones en las que sí lo son los procedentes de $S$. cerevisiae. Esto indicaría que aunque la proteína ( $p 91$ ) y el RNA (20S RNA) pueden asociarse en E. coli para formar complejos estables y específicos, la replicación requiere factores propios de la levadura.

Como conclusión, todos los datos obtenidos indican que no son necesarias proteínas de S. cerevisiae para la formación de los complejos en reposo. Esto parece lógico, ya que el 
virus en este estado se comporta como una forma de resistencia. Estos complejos se forman después de que la célula haya sido sometida a condiciones de estrés, por lo que el gran aumento de virus en estas circunstancias tendría como objetivo asegurar su propagación en las células que sobrevivan. En situaciones en las que peligra la supervivencia de un organismo, hay que ahorrar energía y reducir el metabolismo todo lo posible. Por ello, $20 \mathrm{~S}$ RNA en estas condiciones no necesita ningún tipo de factor para sobrevivir en su hospedador.

Respecto a los factores necesarios durante la replicación activa de 20S RNA, ¿Sería posible estudiarlos en S. cerevisiae? Ya que se trata de algo dinámico, se podrían utilizar mutantes de la levadura que no pueden mantener 20S RNA, o en su defecto, que tengan su cantidad muy disminuida. Pero en este caso surgen problemas, debido a que no hay fenotipo asociado a la presencia de 20S RNA que permita estudios sistemáticos en colecciones de mutantes (Ej. EUROFAM). Sí se pueden estudiar grupos específicos de genes que se sospeche que puedan afectar al metabolismo del RNA, como por ejemplo los genes SKI, que aunque no influyan directamente sobre la replicación de 20S RNA, el efecto sobre el número de copias del virus puede ser indicativo de su implicación en la estabilidad o persistencia.

De modo alternativo, podríamos ver si la presencia del virus, que es persistente, puede modificar o alterar la expresión de determinados genes del hospedador. El aumento en la expresión de uno o varios genes indicaría que se requieren esos factores, mientras que con la disminución se esperaría el papel contrario. Datos preliminares con arrays de DNA indican que sólo hay un pequeño número de genes cuyo patrón de expresión está alterado por la presencia de 20 SNA. En nuestro grupo se está llevando el estudio detallado de alguno de ellos con la esperanza de obtener información acerca de la interrelación que puede haber entre la replicación del virus y el metabolismo del hospedador. 
"Es de importancia para quien desee alcanzar una certeza en su investigación, saber dudar a tiempo"

ARISTÓTELES 
Las conclusiones del trabajo experimental descrito en esta memoria son:

1. Es posible generar el narnavirus 20S RNA en S. cerevisiae a partir de su cDNA clonado en vectores de expresión. El virus generado es estable y se comporta igual que el endógeno. 20S RNA se puede generar tanto a partir de la cadena genómica como de la antigenómica. En este segundo caso se requiere un segundo vector que exprese en trans la polimerasa p91.

2. Mediante genética reversa hemos detectado la existencia de señales en cis importantes en replicación en los extremos 3' de ambas cadenas. En los dos casos, esta señal está compuesta por las cuatro últimas citosinas y la estructura secundaria en horquilla adyacente a las mismas. En esta estructura es importante la longitud del brazo, no así su secuencia primaria ni la secuencia del bucle. Respecto a las cuatro citosinas, la tercera y la cuarta (desde el extremo 3') son necesarias para la generación del virus, no así la primera y segunda que sin embargo, se recuperan en los virus generados en rondas subsiguientes de replicación.

3. Existe in vivo un sistema de reparación muy eficiente para las dos últimas bases de los extremos 3' de 20S RNA, que siempre tienen que ser citosinas. Actualmente no conocemos cómo tiene lugar la reparación de ambas cadenas.

4. Las señales en cis importantes en la replicación de 20S RNA son además señales para la formación de complejos ribonucleoproteicos con p91, resaltando la importancia de la formación de los mismos en el ciclo de replicación del virus. Modificaciones que afectan a la unión del RNA con p91 no permiten generar 20S RNA a partir de vectores.

5. En la generación de 20S RNA, la exonucleasa Xrn1p es la responsable de eliminar la secuencia no viral en $5^{\prime}$ presente en los transcritos primarios expresados a partir del vector. Xrn1p, sin embargo no afecta al número de copias de $20 \mathrm{~S}$ RNA una vez generado. El inicio de su secuencia con cuatro guaninas y una fuerte estructura secundaria en $5^{\prime}$ podría proteger su genoma contra la degradación por esta exonucleasa. 
6. Algunos genes relacionados con la actividad del exosoma como SKI2, SKI3, SKI7 y SKI8 tienen cierto efecto antiviral en S. cerevisiae, ya que en su ausencia la cantidad de $20 \mathrm{~S}$ RNA aumenta de 2 a 5 veces.

7. La formación de los complejos ribonucleoproteicos p91/20S RNA en reposo no requiere proteínas de S. cerevisiae. Hemos detectado su formación en un organismo heterólogo como E. coli cuando 20S RNA y su polimerasa se expresan a partir de plásmidos. Los complejos formados en E. coli sin embargo, no son activos en replicación. 


\section{ANEXOS}

I. TABLAS

II. PUBLICACIONES

1000000 1000000 1000000 1000 O

"iNos ladran Sancho! Señal de que avanzamos" MIGUEL DE CERVANTES 
TABLA 1: Estirpes empleadas en este trabajo

\begin{tabular}{|c|c|c|}
\hline Nombre & Características & Origen \\
\hline \multicolumn{3}{|c|}{ Saccharomyces cerevisiae } \\
\hline 2928 & a ura3 his3 $\Delta 1$ trp1. 20S RNA, 23S RNA-o, L-A-o, L-BC & Esteban (2003) \\
\hline 2928-4 & a ura3 his3 $\Delta 1$ trp1. 20S RNA-o, 23S RNA-O, L-A-o, L-BC & Esteban (2005) \\
\hline 2928-5 & a ura3 his3 $\Delta 1$ trp1. 20S RNA-0, 23S RNA, L-A-O, L-BC & Esteban (2003) \\
\hline 1101 & $\alpha$ kar1-1 his4 (KIL-K1). 20S RNA, 23S RNA-O, L-A, L-BC & Wickner, R. B. ${ }^{\ddagger}$ \\
\hline BY4741 & a his3 $\Delta 1$ leu2 $\Delta 0$ met $15 \Delta 0$ ura3 $\Delta 0$. 20S RNA-o, 23S RNA-o, L-A, L-BC & Revuelta, J. L ${ }^{*}$ \\
\hline XRN1D & $\begin{array}{l}\text { a his3 } \Delta 1 \text { leu2 } \Delta 0 \text { met15 } \Delta 0 \text { ura3 } \Delta 0 \text { XRN1 } 1: \text { kanMX4. 20S RNA-o, 23S RNA-o, } \\
\text { L-A, L-BC }\end{array}$ & Revuelta, J. $L^{\times}$ \\
\hline 880 & 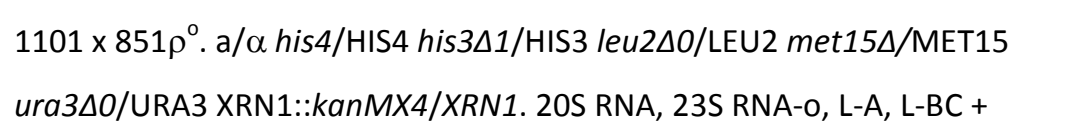 & Este trabajo \\
\hline 882 & $\begin{array}{l}\text { a his3 } \Delta 1 \text { leu2 } \Delta 0 \text { met15 } \Delta 0 \text { ura3 } \Delta 0, X R N 1:: K a n M X 4 \text {. Citoducido XRN1 } \Delta \text { con } \\
\text { 20S RNA. 20S RNA, 23S RNA-o, L-A, L-BC }\end{array}$ & Este trabajo \\
\hline 868 & a ura3 $\triangle 0$ XRN1. Espora 2A (1101 x 851). 20S RNA, 23S RNA-o, L-A, L-BC & Este trabajo \\
\hline 869 & a URA3 XRN1. Espora 2B (1101 x 851). 20S RNA, 23S RNA-o, L-A, L-BC & Este trabajo \\
\hline 870 & a ura3 $\triangle 0$ XRN1. Espora $2 C$ (1101 x 851). 20 S RNA+, $23 S$ RNA-o, L-A, L-BC & Este trabajo \\
\hline 871 & $\begin{array}{l}\text { ๔ URA3 XRN1:: kanMX4. Espora 2D (1101 x 851). 20S RNA, 23S RNA-o, L-A, L- } \\
\text { BC }\end{array}$ & Este trabajo \\
\hline$S K I 2 \Delta$ & BY4741 con $S K I 2 \Delta:: K a n M X 4$. & Revuelta, J. L. ${ }^{\times}$ \\
\hline SKI3ム & BY4741 con SKI3A::KanMX4. & Revuelta, J. L. ${ }^{x}$ \\
\hline SKI7D & BY4741 con SKI7D::KanMX4. & Revuelta, J. L. ${ }^{x}$ \\
\hline SKI8D & BY4741 con SKI8D::KanMX4. & Revuelta, J. L. ${ }^{x}$ \\
\hline 896 & BY4741 con SKI2 $\Delta:: K a n M X 4.20 S$ RNA $^{*}$ & Este trabajo \\
\hline 897 & BY4741 con SKI3 $\triangle:: K a n M X 4.20 S R^{*} A^{*}$ & Este trabajo \\
\hline
\end{tabular}


BY4741con SKI8D::KanMX4. 20S RNA

Este trabajo

913

BY4741 con SKI2A::KanMX4. L-A-O

Este trabajo

923

BY4741 SKI7A::KanMX4. 20S RNA

Este trabajo

924

BY4741 con SKI2A::KanMX4. 20S RNA+ L-A-O

Este trabajo

HSP26D

BY4741 con HSP264::KanMX4.

Revuelta, J. L. ${ }^{\times}$

\section{Escherichia coli}

\begin{tabular}{|c|c|c|}
\hline DH5 $\alpha$ & $\begin{array}{l}\mathrm{F}^{-} \text {endA1 gInV44 thi-1 recA1 relA1 gyrA96 deoR nupG } \Phi 80 \Delta / a c Z \Delta \mathrm{M} 15 \\
\Delta(\text { lacZYA-argF }) \cup 169, \operatorname{hsdR} 17\left(\mathrm{r}_{\mathrm{K}}^{-} \mathrm{m}_{\mathrm{K}}^{+}\right), \lambda-\end{array}$ & Meselson (1968) \\
\hline CJ236 & $\mathrm{F}^{\prime}$, dut1, ung1, thi-1, relA1/pCJ105(F' cam $\left.^{\mathrm{r}}\right)$ & Joyce (1984) \\
\hline BL21 (DE3) & $\mathrm{F}^{-}$ompT gal dcm lon hsdS $\mathrm{S}_{B}\left(\mathrm{r}_{\mathrm{B}}^{-} \mathrm{m}_{\mathrm{B}}^{-}\right) \lambda(\mathrm{DE} 3) \operatorname{pLysS}\left(\mathrm{cm}^{\mathrm{R}}\right)$ & Studier (1986) \\
\hline
\end{tabular}

${ }^{\ddagger}$ Dr. R. B. Wickner, Nacional Institutes of Health, Bethesda, MD (USA).

${ }^{x}$ Dr. J. L. Revuelta. Departamento de Microbiología y Genética. Universidad de Salamanca.

Functional Analysis of Yeast Genes Discovered by Systematic DNA Sequencing:

(EUROFAN 1). CE. BIO4-CT95-0080/CICYT BIO96-1760-C04-04-CE. 1996-1998.

(EUROFAN 2). CE. BIO4-CT97-2294/CICYT BIO98-1515-CE. 1997-2000.

₹ El virus 20S RNA fue generado en estas cepas a partir de un vector de expresión.

¿ Estas cepas fueron creadas mediante la eliminación del virus L-A por crecimiento a alta temperatura. 
TABLA 2: Oligonucleótidos empleados en las mutagénesis dirigidas in vitro

\begin{tabular}{|c|c|c|}
\hline Nombre & Secuencia & Características \\
\hline \multicolumn{3}{|c|}{ Mutagénesis dirigida in vitro } \\
\hline LV1 & GCCGATTTGGGGGCGTGGCCTCAGG & $\begin{array}{l}\text { Cambio G5C en } 20 S \text { RNA con la ribozima } \\
\text { modificada. }\end{array}$ \\
\hline LV2 & ATGCCGATTTGGIGCCGTGGCCTCA & $\begin{array}{l}\text { Cambio C3A en } 20 S \text { RNA con la ribozima } \\
\text { modificada. }\end{array}$ \\
\hline LV3 & CATGCCGATTTGIGGCCGTGGCCTC & $\begin{array}{l}\text { Cambio C2A en } 20 S \text { RNA con la ribozima } \\
\text { modificada. }\end{array}$ \\
\hline LV4 & CCATGCCGATTTIIGGGCCGTGGCCT & $\begin{array}{l}\text { Cambio C1A en } 20 S \text { RNA con la ribozima } \\
\text { modificada. }\end{array}$ \\
\hline LV9 & CATGGGATCAGCCCCAAGTAGATAATTACT & $\begin{array}{l}\text { Elimina } 28 \text { nts que hay entre el extremo } 5^{\prime} \text { de } \\
20 S \text { RNA y el inicio de la transcripción del } \\
\text { promotor PGK1 (deja } 19 \mathrm{nt} \text { ). }\end{array}$ \\
\hline LV10 & CATGGGATCAGCCCCITACTTCCTTGATGA & $\begin{array}{l}\text { Elimina } 38 \text { nts que hay entre el extremo } 5^{\prime} \text { de } \\
20 S \text { RNA y el inicio de la transcripción del } \\
\text { promotor PGK1 (deja } 9 \mathrm{nt} \text { ). }\end{array}$ \\
\hline LV11 & CATGGGATCAGCCCCTTGATGATCTGTAAA & $\begin{array}{l}\text { Elimina los } 47 \text { nts que hay delante del extremo } \\
5^{\prime} \text { de } 20 \text { S RNA hasta el inicio de la transcripción } \\
\text { de PGK1. }\end{array}$ \\
\hline LV16 & CGACCCGGGGCCGGGICTCAGGGGA & Cambio A8G sobre pRE797 (G11A). \\
\hline LV18 & CCTCAGGGGAAAGCCGAGACCACGG & Cambio G23C de 20S RNA. \\
\hline LV19 & GGGGAAACCCGACACCACGGTGGAT & Cambio C28G de 20S RNA. \\
\hline LV20 & GCCGACCCGGGGACTGATCCCATGAA & Cambio G5U + G en la cadena (-) de 20S RNA. \\
\hline LV21 & 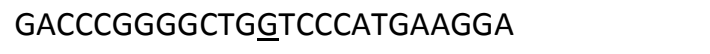 & Cambio U8C en la cadena (-) de 20S RNA. \\
\hline LV22 & 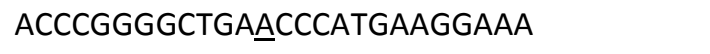 & Cambio A9U en la cadena (-) de 20S RNA. \\
\hline LV23 & ACCCGGGGCTGACCCATGAAGGAA & Cambio A9G en la cadena (-) de 20S RNA. \\
\hline LV24 & CCCGGGGCTGATICCATGAAGGAAC & Cambio G10A en la cadena (-) de 20S RNA. \\
\hline LV25 & 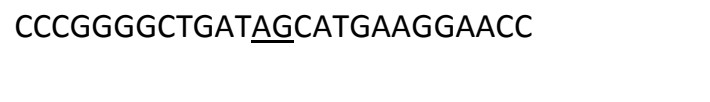 & $\begin{array}{l}\text { Cambio G10U+G11C en la cadena (-) de } 20 S \\
\text { RNA. }\end{array}$ \\
\hline LV32 & CCGTGGCCTCAGGGGAAATCCGAGACCACGG & Cambio G23A de 20S RNA. \\
\hline LV35 & $\begin{array}{l}\text { CCGGGGCCGTGGACTCAGGGGAAACCCGACACCA } \\
\text { CGGTGGAT }\end{array}$ & Cambio $\mathrm{C} 28 \mathrm{G}+\mathrm{G} 11 \mathrm{U}$ de $20 \mathrm{~S}$ RNA. \\
\hline LV36 & CCCGGGGCTGATTGGATGAAGGAACCA & $\begin{array}{l}\text { Cambio } \mathrm{G} 10 \mathrm{~A}+\mathrm{G} 11 \mathrm{C}+\mathrm{G} 12 \mathrm{C} \text { en la cadena (-) de } \\
\text { 20S RNA. }\end{array}$ \\
\hline
\end{tabular}




\begin{tabular}{|c|c|}
\hline LV37 & GACCCGGGGCTGCACCCATGAAGGAA \\
\hline LV41bis & GCCGACCCGGGGGGATCCTGTCAGGGGAAAC \\
\hline LV42 & CCCGGGGCCGTGGACTCAGGGGAAAC \\
\hline LV62 & $\begin{array}{l}\text { GATTGTCGCGTTTGCGAATTCGATCTAATCGGCGT } \\
\text { G }\end{array}$ \\
\hline RE148 & $\begin{array}{l}\text { CCATGCCGACCCGGGGCCGTGGCCTCAGGGGAAA } \\
\text { CCCG }\end{array}$ \\
\hline RE163 & TGCCATGCCGACCCIGGGCCGTGGCCTCA \\
\hline RE164 & GCCATGCCGACCCGIGGCCGTGGCCTCAGG \\
\hline RE165 & CCATGCCGACCCGGIGCCGTGGCCTCAGG \\
\hline RE166 & CATGCCGACCCGGGICCGTGGCCTCAGGG \\
\hline RE167 & TGCCATGCCGACCCGGCCGTGGCCTCAG \\
\hline RE189 & $\begin{array}{l}\text { GGGATGATCCTCTCCCCGGGCAAGCACTTCCGCAG } \\
\text { T }\end{array}$ \\
\hline RE193 & GATGCCATGCCGACCCCGGGGGCCGTGGCCTCAG \\
\hline RE194 & GATGCCATGCCGACCCGGGGGCCGTGGCCTCAG \\
\hline RE195 & GATGCCATGCCGACCCAGGGGCCGTGGCCTCAG \\
\hline RE196 & $\begin{array}{l}\text { GATGCCATGCCGACCCGGGGGGGCCGTGGCCTCA } \\
\text { G }\end{array}$ \\
\hline RE197 & GATGCCATGCCGACCCCCCGGGGCCGTGGCCTCAG \\
\hline RE203 & GATGCCATGCCGACCCTGGGCTGATCCCATGAA \\
\hline RE204 & ATGCCATGCCGACCCGTGGCTGATCCCATGAAG \\
\hline RE205 & TGCCATGCCGACCCGGIGCTGATCCCATGAAGG \\
\hline RE206 & GCCATGCCGACCCGGGICTGATCCCATGAAGGA \\
\hline RE208 & AGCCAGTTGGGAAACAGCAAGTCGCCCATCCGGC \\
\hline
\end{tabular}

Cambio U8G+A9U en la cadena (-) de 20S RNA.

Se modifica toda la secuencia comprendida entre el codón Stop de p91 y las cuatro Cs del extremo 3 ' de 20 R RNA.

Cambio G11U en 20S RNA.

Cambio de la región GDD de p91. Los aminoácidos nuevos son EFD. Se crea un sitio de restricción EcoRI nuevo. Para modificar pLOR 91.

Introduce 6 bases casi en el extremo 3' de 20 S RNA para estar completo y bien.

Cambio C1A en 20S RNA.

Cambio C2A en 20 S RNA.

Cambio C3A en 20S RNA.

Cambio C4A en 20S RNA.

Se eliminan las dos últimas bases del extremo $3^{\prime}$ 'de 20 S RNA

Se introduce un sitio Smal en la secuencia de 20S RNA, alrededor de la base 1400 .

Añade una guanina después de la secuencia de 20S RNA.

Añade una citosina despues de la secuencia de 20S RNA.

Añade un uracilo después de la secuencia de 2OS RNA

Añade tres citosinas después de la secuencia de 20S RNA.

Añade tres guaninas después de la secuencia de 20S RNA

C1A en el extremo $3^{\prime}$ de la cadena (-) de $20 \mathrm{~S}$ RNA.

C2A en el extremo $3^{\prime}$ de la cadena (-) de $20 \mathrm{~S}$ RNA.

C3A en el extremo $3^{\prime}$ de la cadena (-) de $20 \mathrm{~S}$ RNA.

C4A en el extremo $3^{\prime}$ de la cadena (-) de $20 \mathrm{~S}$ RNA.

Modifica la segunda horquilla del extremo $3^{\prime}$ de 


\begin{tabular}{|c|c|c|}
\hline & & \\
\hline & & 20S RNA U63C+A64G. \\
\hline RE209 & TGGGAAACAATAAGTCTCCCATCCGGCCCTCAC & $\begin{array}{l}\text { Modifica la segunda horquilla del extremo } 3^{\prime} \text { de } \\
\text { 20S RNA C70A. }\end{array}$ \\
\hline RE214 & TAAGTCGCCCATACGGCCCTCACGC & $\begin{array}{l}\text { Modifica la segunda horquilla del extremo } 3^{\prime} \text { de } \\
\text { 20S RNA G76U. }\end{array}$ \\
\hline RE215 & GGTGGATGGTGGIAGCCAGTTGGGA & $\begin{array}{l}\text { Modifica la segunda horquilla del extremo } 3^{\prime} \text { de } \\
\text { 20S RNA U46A. }\end{array}$ \\
\hline RE216 & CATCCGGCCCTCICICATCAAGCCGGC & $\begin{array}{l}\text { Modifica la segunda horquilla del extremo } 3^{\prime} \text { de } \\
\text { 20S RNA U78A+C80A. }\end{array}$ \\
\hline RE234 & GCCGACCCGGGGGCGTGGCCTCAGG & G5C en el extremo 3' de 20 S RNA. \\
\hline RE236 & TGATCCCATGAAAGAACCAGTAGAC & $\begin{array}{l}\text { C18U en el extremo } 3^{\prime} \text { de la cadena (-) de } 20 \mathrm{~S} \\
\text { RNA. }\end{array}$ \\
\hline RE238 & CATGAAGGAACCGGTAGACTGCCGT & $\begin{array}{l}\text { U24C en el extremo } 3^{\prime} \text { de la cadena (-) de } 20 \mathrm{~S} \\
\text { RNA. }\end{array}$ \\
\hline RE242 & CCGAGACCACGGAGGATGGTGGAAG & Cambio de la treonina 823 a serina en $p 91$. \\
\hline RE246 & CCCGAGACCACGCTGGATGGTGGAA & C35G en el extremo $3^{\prime}$ de 20 S RNA. \\
\hline RE252 & ATGCCATGCCGATTTGGGGCCGTGGCC & $\begin{array}{l}\text { Modifica el sitio de corte de la ribozima en la } \\
\text { cadena (+) de 20S RNA (GGG } \rightarrow \text { AAA). }\end{array}$ \\
\hline RE256 & ATGCCATGCCGATTTGGGICCGTGGCCTCAG & $\begin{array}{l}\text { C4A en 20S RNA con la ribozima modificada Para } \\
\text { hacer estudios de unión 3'-p91. }\end{array}$ \\
\hline \multicolumn{3}{|c|}{ Secuenciación } \\
\hline RE79 & TACTCGTTTTAGGACTGG & $\begin{array}{l}\text { Para secuenciar el extremo } 3^{\prime} \text { de } 20 \text { RNA. Anilla } \\
\text { en el vector a } 170 \text { nt del extremo del cDNA. Se } \\
\text { utilizó rutinariamente para comprobar los } \\
\text { cambios introdicidos en el extremo mediante } \\
\text { mutaciones in vitro. }\end{array}$ \\
\hline TW1 & GAGAACTCCTTCGCAGAA & $\begin{array}{l}\text { Anilla con la zona anterior del extremo } 5^{\prime} \text { de } 20 \mathrm{~S} \\
\text { RNA. }\end{array}$ \\
\hline Universal & GTTGTAAAACGACGGCCAGT & $\begin{array}{l}\text { Anilla a } 20 \mathrm{nt} \text { del promotor de la T7 RNA } \\
\text { polimerasa. }\end{array}$ \\
\hline Reverso & CACAGGAAACAGCTATGACC & $\begin{array}{l}\text { Anilla a } 20 \mathrm{nt} \text { del promotor de la T3 RNA } \\
\text { polimerasa. }\end{array}$ \\
\hline
\end{tabular}


TABLA 3: Plásmidos utilizados en este trabajo

\begin{tabular}{|c|c|}
\hline Nombre & Características \\
\hline \multicolumn{2}{|c|}{ Saccharomyces cerevisiae } \\
\hline pRE740 & Genera el virus 20S RNA. Marcador TRP1. \\
\hline pRE757 & (pRE740/RE163). C1A en el extremo 3' de la cadena (+) de 20S RNA (...GCCCA-OH). \\
\hline pRE758 & (pRE740/RE164). C2A en el extremo 3' de la cadena (+) de 20S RNA (...GCCAC-OH). \\
\hline pRE759 & $\begin{array}{l}\text { (pRE740/RE167). Se eliminan las dos últimas bases en el extremo } 3^{\prime} \text { de la cadena }(+) \text { de } 20 \text { S RNA } \\
(\ldots \text { GCC_-OH). }\end{array}$ \\
\hline pRE760 & (pRE740/RE165). C3A en el extremo 3' de la cadena (+) de 20S RNA (...GCACC-OH). \\
\hline pRE762 & Se introduce 20S RNA en sentido opuesto. Marcador URA3 \\
\hline pRE763 & $\begin{array}{l}\text { Subclonación de } 20 \text { S RNA en sentido correcto en un plásmido que tenía } 23 S \text { RNA. Genera el virus } \\
\text { 20S RNA. Marcador URA3. }\end{array}$ \\
\hline pRE786 & $\begin{array}{l}\text { (pRE740/RE166). Se elimina la última base en el extremo } 3^{\prime} \text { de la cadena }(+) \text { de } 20 \text { S RNA } \\
\text { (...GCCC_-OH). }\end{array}$ \\
\hline pRE787 & (pRE740/RE166). C4A en el extremo 3' de la cadena (+) de 20S RNA (...GCACC-OH). \\
\hline pRE793 & (pRE740/RE197). Se añaden tres guaninas al extremo 3' de 20S RNA. (...GCCCCGGG-OH). \\
\hline pRE794 & (pRE740/RE195). Se añade un uracilo al extremo 3' de 20S RNA. (...GCCCCU-OH). \\
\hline pRE795 & (pRE740/RE196). Se añaden tres citosinas al extremo 3' de 20S RNA. (...GCCCCCCC-OH). \\
\hline pRE797 & (pRE740/RE191). G11A en el extremo 3' de 20S. Se mantiene la complementariedad. \\
\hline pRE800 & (pRE740/RE193). Se añade una guanina al extemo 3' de 20S RNA. (...GCCCCG-OH). \\
\hline pRE805 & (pRE762/RE189). Se introduce un sitio interno Smal en 20S RNA en sentido inverso. \\
\hline pRE806 & (pRE762/RE203). C1A en el extremo 3' de la cadena (-) de 20S RNA. \\
\hline pRE809 & (pRE740/RE209). C70A en la 2a horquilla del extremo 3' de 20S RNA. \\
\hline pRE810 & (pRE740/RE215). U46A en la 2a horquilla del extremo 3' de 20S RNA. \\
\hline pRE811 & (pRE740/RE216). U78A+C80A en la 2a horquilla del extremo 3' de 20S RNA. \\
\hline pRE812 & (pRE740/RE194). Se añade una citosina en el extremo 3' de 20S RNA. (...GCCCCC-OH). \\
\hline pRE813 & (pRE740/RE214). G67U en la 2a horquilla del extremo 3' de 20S RNA. \\
\hline pRE815 & (pRE762/RE204). C2A en el extremo 3' de la cadena (-) de 20S RNA. \\
\hline pRE816 & (pRE762/RE205). C3A en el extremo 3' de la cadena (-) de 20S RNA. \\
\hline pRE817 & (pRE762/RE206). C4A en el extremo 3' de la cadena (-) de 20S RNA. \\
\hline
\end{tabular}


PRE819

PRE824

PRE843

PRE848

\section{PRE849}

PRE850

PRE856

PRE905

PRE908

PRE914

PLOR7

PLOR11

pLOR12

pLOR14

pLOR16

pLOR17

pLOR18

PLOR20

pLOR24

PLOR25

pLOR26

pLOR35

pLOR36

(pRE740/RE208). U63C+A64G en la 2ª horquilla del extremo 3' de 20S RNA.

(pRE762/RE206)Se elimina la última C en el extremo 3' de la cadena (-) de 20S RNA.

(pRE740/RE234). G5C cambio en la parte 3' de la horquilla del extremo 3' de 20S RNA.

(pRE843/RE246) Se introduce la mutación compesatoria G35C en el plásmido con la quinta guanina modificada a citosina en el otro extremo de la horquilla.

(pRE740/RE246). C35G cambio en la parte 5' de la horquilla del extremo 3' de 20S RNA. Se abre en una base y además se cambia la treonina 823 a serina en $p 91$.

(pRE740/RE242). Se cambia la treonina 823 a serina en p91, sin modificar la estructura secundaria

(pRE740/RE256). Se modifica la ribozima en el extremo 3' de 20S RNA en y además la cuarta base desde el extremo $3^{\prime}$ a adenina. (...GACCCAAA...)

pBluescript KS+ + Gen XRN1/SKI1 (CON PROMOTOR Y TERMINADOR) amplificado por PCR con los oligos RE298 Y RE299 a partir de la cepa 2928-4.

Expresa el gen XRN1 a partir de su propio promotor en un plásmido centromérico (pRS313) de $S$. cerevisiae.

ORF del gen XRN1 amplificada con los oligos RE296 y RE297 a partir de DNA de la cepa 2928-4 y clonada en el plásmido pl2 de S. cerevisiae para sobreexpresar la proteína Xrn1p.

(pRE740/RE252). Se modifican las primeras bases de la ribozima, GGG pasan a AAA.

(pLOR7/LV4). Cambio C2A en 3' de 20S RNA con la ribozima modificada.

(pRE805/RE237). Cambio U21C en el extremo 3' de la cadena (-) de 20S RNA.

(pLOR7/LV1). Cambio G5C en 3' de 20S RNA con la ribozima modificada.

(pRE805/RE236). Cambio C18U en el extremo 3' de la cadena (-) de 20S RNA.

(pLOR7/LV3). Cambio C3A en 3' de 20S RNA con la ribozima modificada.

(pRE805/RE238). Cambio U24C en el extremo 3' de la cadena (-) de 20S RNA.

(pLOR7/LV2). Cambio C1A en 3' de 20S RNA con la ribozima modificada.

(pRE848/LV1). Se modifican las primeras bases de la ribozima, GGG $\rightarrow$ AAA, en el plásmido $p R E 848$, que tiene la quinta $\mathrm{G}$ cambiada a $\mathrm{C}$, así como la mutación complementaria en el extremo $5^{\prime}$ de la horquilla en $3^{\prime}$.

(pRE850/RE252). Se modifican las primeras bases de la ribozima, GGG $\rightarrow$ AAA, en el plásmido pRE850, que tiene la treonina 823 a serina en p91, sin modificar la estructura secundaria.

(pRE849/RE252). Se modifican las primeras bases de la ribozima, GGG $\rightarrow$ AAA, en el plásmido pRE849, que tiene la citosina de la parte $5^{\prime}$ del stem del extremo $3^{\prime}$ cambiada a G. Se cambia la treonina 823 a serina en $p 91$.

(pRE763/LV10). Se eliminan 28 nts que hay entre el extremo 5' de 20S RNA y el promotor PGK1 a partir del extremo 5' de la secuencia de 20 S RNA.

(pRE763/LV11). Se eliminan los 47 nt que hay entre el extremo $5^{\prime}$ de la secuencia de 20 S RNA y el inicio de la transcripción del promotor PGK1. 


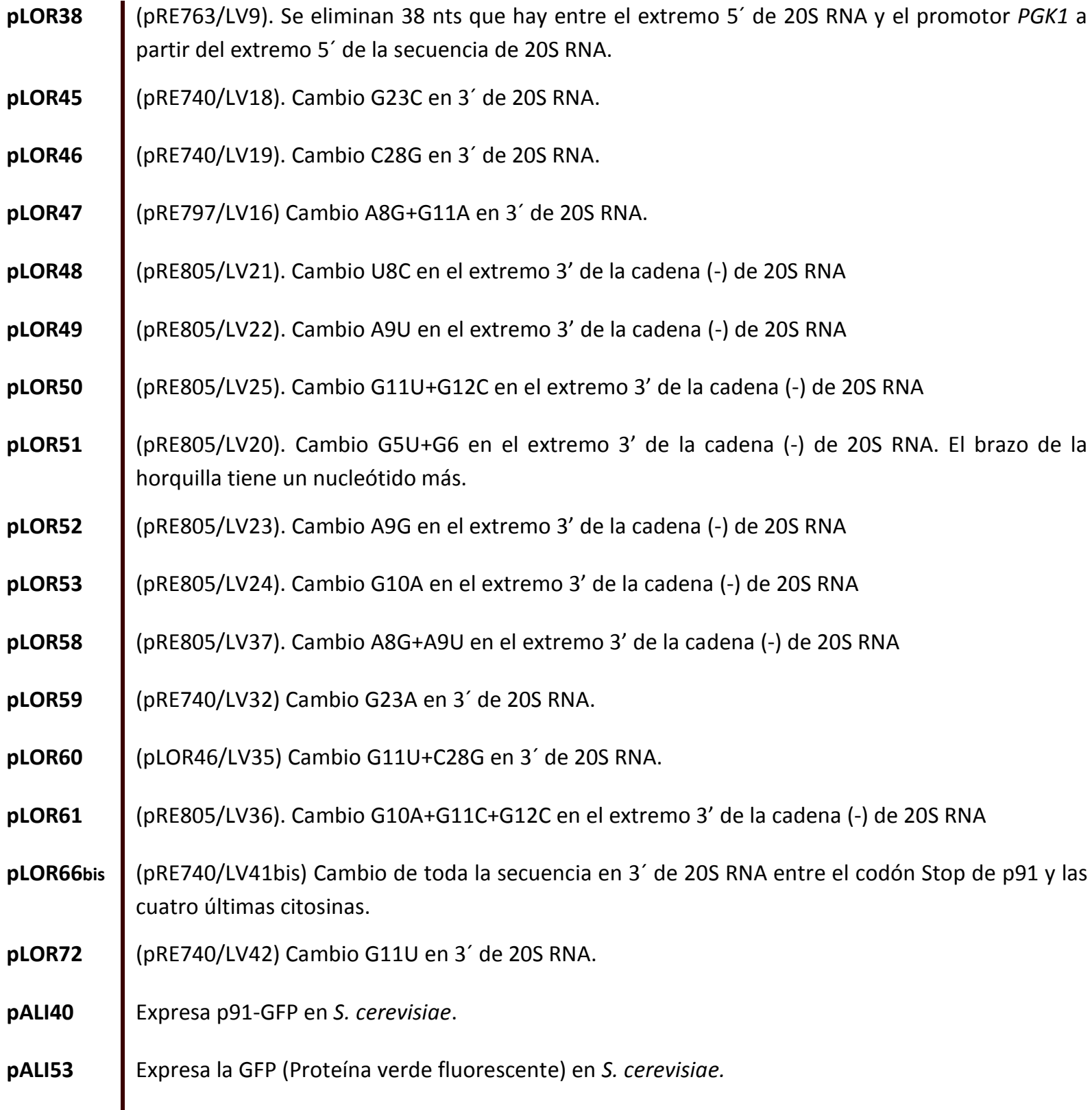

Escherichia coli

\begin{tabular}{|c|c|}
\hline pLM62+ & pT7-7 con el origen de replicación del fago M13. \\
\hline pALI17 & $\begin{array}{l}\text { pBluescript KS+ con la secuencia de } 20 \text { SNA completa. Sirve para sintetizar in vitro la cadena (+) } \\
\text { de } 20 \text { S RNA (digiriendo con Smal y usando la T7 RNA polimerasa) }\end{array}$ \\
\hline pRE449 & $\begin{array}{l}\text { pBluescript KS+ con la secuencia de } 20 \text { SNA desde la base } 1253-2514 \text {. Sirve para hacer sonda de } \\
20 \text { S RNA. Digerido con BamHI/T3, específica de la cadena (+), y con Smal/T7 de la cadena (-). }\end{array}$ \\
\hline pRE553 & $\begin{array}{l}\text { pBluescript KS+ que tiene insertado un fragmento de } 85 \text { bp que contiene la secuencia } \\
\text { antigenómica de la ribozima del virus delta de la hepatitis (HDV). Digerido con Pvull/T3 se puede } \\
\text { utilizar como sonda específica de la cadena (+) de la ribozima. }\end{array}$ \\
\hline pLOR91 & $\begin{array}{l}\text { Se sustituye } 235 \text { RNA por } 20 S \text { RNA en un plásmido derivado del pLM62+ con resistencia a } \\
\text { Kanamicina. }\end{array}$ \\
\hline pLOR92 & $\begin{array}{l}\text { Se añade la ribozima al extremo 3' de } 20 \text { SNA fusionado al promotor de la T7 RNA polimerasa. } \\
\text { (pLOR91/LV62). Modificación de la zona GDD de p91 para generar una fuente de proteína }\end{array}$ \\
\hline
\end{tabular}




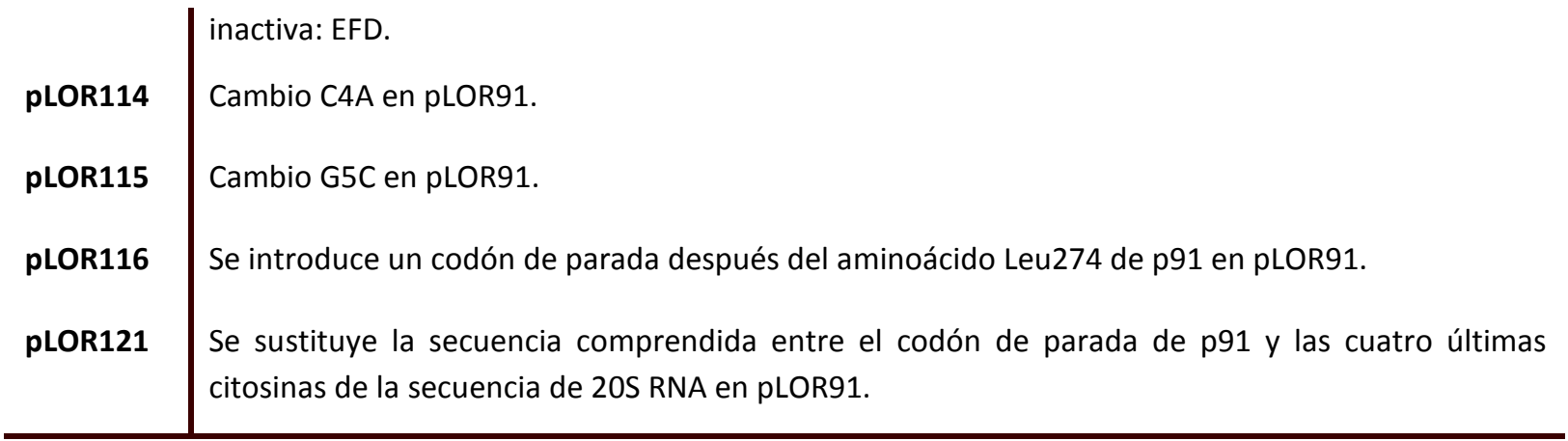




\title{
Launching of the Yeast 20 S RNA Narnavirus by Expressing the Genomic or Antigenomic Viral RNA in Vivo*
}

Received for publication, June 16, 2005, and in revised form, July 25, 2005 Published, JBC Papers in Press, July 27, 2005, DOI 10.1074/jbc.M506546200

\author{
Rosa Esteban ${ }^{1}$, Lorena Vega ${ }^{2}$, and Tsutomu Fujimura ${ }^{3}$ \\ From the Instituto de Microbiología Bioquímica/Departamento de Microbiología y Genética, Consejo Superior de Investigaciones \\ Científicas/Universidad de Salamanca, Salamanca 37007, Spain
}

$20 \mathrm{~S}$ RNA virus is a persistent positive strand RNA virus found in Saccharomyces cerevisiae. The viral genome encodes only its RNA polymerase, $\mathrm{p} 91$, and resides in the cytoplasm in the form of a ribonucleoprotein complex with p91. We succeeded in generating $20 \mathrm{~S}$ RNA virus in vivo by expressing, from a vector, genomic strands fused at the $3^{\prime}$-ends to the hepatitis delta virus antigenomic ribozyme. Using this launching system, we analyzed 3 ' -cis-signals present in the genomic strand for replication. The viral genome has five-nucleotide inverted repeats at both termini (5'-GGGGC ... $\mathrm{GCCCC}-\mathrm{OH})$. The fifth $\mathrm{G}$ from the $3^{\prime}$-end was dispensable for replication, whereas the third and fourth Cs were essential. The $3^{\prime}$-terminal and penultimate Cs could be eliminated or modified to other nucleotides; however, the generated viruses recovered these terminal Cs. Furthermore, extra nucleotides added at the viral $3^{\prime}$-end were eliminated in the launched viruses. Therefore, $20 \mathrm{~S}$ RNA virus has a mechanism(s) to maintain the correct size and sequence of the viral 3 ' -end. This may contribute to its persistent infection in yeast. We also succeeded in generating $20 \mathrm{~S}$ RNA virus similarly from antigenomic strands provided active p91 was supplied from a second vector in trans. Again, a cluster of four Cs at the $3^{\prime}$-end in the antigenomic strand was essential for replication. In this work, we also present the first conclusive evidence that $20 \mathrm{~S}$ and $23 \mathrm{~S}$ RNA viruses are independent replicons.

Positive strand RNA viruses encode RNA-dependent RNA polymerases in their genomes and utilize them to synthesize viral RNA in conjunction with other viral or host proteins (1). The antigenomic (negative) strand RNA is an intermediate of replication and serves as a template to synthesize progeny positive strands. Because viral replication takes place within the host cell and because there are plenty of cellular RNAs in these cells, the viruses must find efficiently not only the positive strands but also the negative strands during replication. Therefore, both the positive and negative strands bear cis-acting signals for replication, including those necessary to interact with the polymerase machinery. To analyze and characterize these signals, it is essential to develop appropriate in vivo or in vitro systems in which changes in the signals can be tested.

$20 \mathrm{~S}$ and $23 \mathrm{~S}$ RNAs are positive strand RNA viruses found in Saccharomyces cerevisiae and belong to the genus Narnavirus (2). These

\footnotetext{
* This work was supported in part by Grants BMC2001-1065 and BFU2004-00373 from the Spanish Ministry of Education and Science. The costs of publication of this article were defrayed in part by the payment of page charges. This article must therefore be hereby marked "advertisement" in accordance with 18 U.S.C. Section 1734 solely to indicate this fact.

${ }^{1}$ To whom correspondence should be addressed: Inst. de Microbiología Bioquímica, CSIC/Universidad de Salamanca, Avda. del Campo Charro s/n, Salamanca 37007 Spain. Tel.: 34-923-120-673; Fax: 34-923-224-876; E-mail: mrosa@gugu.usal.es.

${ }^{2}$ Recipient of a fellowship from the Autonomous Regional Government of Castilla and León (Spain) and the European Fund for Regional Development.

3 Recipient of a contract from the Spanish Research Program "Ramón y Cajal."
}

viruses were initially identified as RNA species induced in cells under nitrogen starvation conditions $(3,4)$. Most laboratory strains carry $20 \mathrm{~S}$ RNA, and fewer strains harbor 23 S RNA along with 20 S RNA. They are compatible in the same host cell. Because all known strains that carry 23 S RNA also carry 20 S RNA, it has not been clear whether 23 S RNA virus can replicate without $20 \mathrm{~S}$ RNA virus. Typical of fungal viruses, they are not infectious and have no extracellular pathways of transmission. They are transmitted horizontally through mating or vertically from mother to daughter cells. No curing methods to eliminate these viruses from yeast are known so far. Furthermore, $20 \mathrm{~S}$ and $23 \mathrm{~S}$ RNA viruses do not confer any phenotypic changes on the host. This makes their genetic manipulation difficult.

The $20 \mathrm{~S}$ and $23 \mathrm{~S}$ RNA genomes are small (2514 and 2891 nucleotides, respectively), and each RNA encodes only a single protein: a 91-kDa protein (p91) and a 104-kDa (p104), respectively (5-8). Both proteins contain four amino acid motifs well conserved among RNAdependent RNA polymerases (9). When yeast cells are grown at $37^{\circ} \mathrm{C}$, the cells accumulate double-stranded RNAs called W and T (10), the double-stranded forms of $20 \mathrm{~S}$ and 23 S RNA genomes, respectively (8). They are not replication intermediates, but by-products (11). Because these viruses do not have genes for capsid proteins, their genomes are not encapsidated into intracellular viral particles (12-14). Instead, the RNAs form ribonucleoprotein complexes with their cognate RNA-dependent RNA polymerases at a 1:1 stoichiometry and reside in the cytoplasm (15). The viral genomes lack poly(A) tails at the $3^{\prime}$-ends and have perhaps no $5^{\prime}$-cap structures (8), thus resembling degradation intermediates of mRNAs. How these viruses can survive as persistent viruses in the host cytoplasm without their RNA genomes being digested by exonucleases involved in mRNA degradation is therefore interesting.

Recently, we succeeded in generating 23 S RNA virus in vivo from a vector containing the entire cDNA sequence of the viral genome (16). Using this launching system, we began reverse genetics to investigate cis-acting signals for replication in 23 S RNA virus. $20 \mathrm{~S}$ and 23 S RNA genomes share five-nucleotide inverted repeats at the $5^{\prime}$ and $3^{\prime}$ termini (5'-GGGGC ... GCCCC-OH) (8). The $23 \mathrm{~S}$ RNA genome contains a bipartite cis-signal in the $3^{\prime}$-region that consists of the cluster of the terminal four Cs and a mismatched pair of purines present in a stem structure adjacent to the $3{ }^{\prime}$-end (17). Although the $3{ }^{\prime}$-terminal and penultimate Cs are dispensable for launching 23 S RNA virus, the generated viruses recover these Cs. This indicates that the virus has an efficient $3^{\prime}$-terminal repair mechanism(s). Subsequently, we found that the bipartite $3^{\prime}$-cis-signal for replication is also essential for formation of ribonucleoprotein complexes in vivo with its RNA-dependent RNA polymerase, p104 (18). This indicates the importance of complex formation for $23 \mathrm{~S}$ RNA virus and suggests that 104 protects the viral 3 '-ends from degradation by binding to the 3 '-cis-signal.

In this work, we describe the generation of $20 \mathrm{~S}$ RNA virus in vivo from a vector, a system similar to the one developed previously for $23 \mathrm{~S}$ RNA virus (16). In contrast to the previous work, however, we suc- 


\section{Launching of 20 S RNA Virus from Positive/Negative Strands}

ceeded in producing $20 \mathrm{~S}$ RNA virus not only from positive strands but also from negative strands if, in the latter case, active p91 was provided in trans from a second vector. Using these systems, we modified the viral $3^{\prime}$-ends and found that the clusters of the $3^{\prime}$-terminal four Cs in both the positive and negative strands are $3^{\prime}$-cis-signals for replication. We also provide, for the first time, conclusive evidence that $23 \mathrm{~S}$ RNA virus does not require $20 \mathrm{~S}$ RNA virus for replication; thus, they are independent replicons.

\section{EXPERIMENTAL PROCEDURES}

Strains and Media-20 S RNA negative strains 2928-4 and 2928-5 were obtained in this work (see Fig. 1) from strain 2928 L-A-o (a ura3 trp1 his3, 20 S RNA, 23 S RNA-o, L-A-o) (16). These strains were used to analyze launching of $20 \mathrm{~S}$ RNA virus from plasmids. Cells were grown in rich YPAD medium (1\% yeast extract, $2 \%$ peptone, $0.04 \%$ adenine sulfate, and $2 \%$ glucose) or synthetic medium deprived of tryptophan, uracil, or both (19). Nitrogen starvation in 1\% potassium acetate was performed as described previously (4).

Northern Hybridization-Cells were broken with glass beads (15), and RNA was extracted from cell lysates once with phenol and twice with phenol/chloroform and precipitated with ethanol. RNA was separated on an agarose gel, blotted onto a neutral nylon membrane (Hybond-N, Amersham Biosciences), and hybridized with a ${ }^{32} \mathrm{P}$-labeled 20 S RNA or 23 S RNA positive or negative strand-specific probe (20). We analyzed 5-10 independent transformants in each experiment. For the sake of simplicity, only a representative of each experiment is presented in the figures.

Plasmids-The standard 20 S RNA virus-launching plasmid pRE740 contains the entire 20 S RNA cDNA sequence (2514 bp) downstream of the PGK1 promoter in a pI2 derivative (21). The hepatitis delta virus $(\mathrm{HDV})^{4}$ antigenomic ribozyme was directly fused to the 3 ' -end of the 20 S RNA cDNA genome (see Fig. $2 A$ ). There are 42 nucleotides between the major transcription start site from the PGK1 promoter and the $20 \mathrm{~S}$ RNA sequence. Transcripts from this vector have 20 S RNA positive strand polarity. The template plasmid pRE805 is similar to pRE740, but the orientation of the $20 \mathrm{~S}$ RNA cDNA is reversed. Therefore, transcripts from the $P G K 1$ promoter have the negative strand polarity of the viral genome. In addition, the TRP1 marker of this plasmid was disrupted at the unique EcoRV site by insertion of a 1.1-kb URA3 fragment. 20 S RNA positive and negative strand-specific probes were made by T7 and T3 runoff transcription from pRE449 predigested with appropriate restriction enzymes. pRE449 contains a 1262-bp BamHI-SmaI fragment (nucleotides 1253-2514) of the 20 S RNA cDNA sequence between the BamHI and SamI sites of the pBluescript $\mathrm{KS}^{+}$vector (Stratagene). $23 \mathrm{~S}$ RNA positive strand-specific probes were made from plasmid pALI38 as described (15). In vitro mutagenesis was performed as described (22). All mutations introduced were confirmed by DNA sequencing.

Reverse Transcription (RT)-PCR-To prove that 20 S RNA virus was generated from plasmids, a DNA fragment of 842 bp was amplified by RT-PCR from lysates using internal primers RE171 (5' -CGCTTCTGCGATCGTAGATG-3') and ALI-3 (5'-TAAAACTGTATGCAGCAG$\left.3^{\prime}\right)$. The lysates were prepared from 20 S RNA virus-generated cells from which the launching plasmids had been cured or from cells containing endogenous 20 S RNA virus. In either case, the lysate was pretreated with DNase I before RT-PCR. The RT-PCR products were then digested with SmaI and analyzed on agarose gels.

3'-Rapid Amplification of cDNA Ends (RACE)-Total RNA isolated by launching plasmid-cured cells was poly(A)-tailed using poly(A)

\footnotetext{
${ }^{4}$ The abbreviations used are: HDV, hepatitis delta virus; RT, reverse transcription; RACE, rapid amplification of cDNA ends.
}

polymerase (Invitrogen). The poly(A)-tailed RNA was denatured with hydroxymethylmercuric hydroxide as described (23), and cDNA was synthesized using oligonucleotide RE156 (5'-GACTCGAGTCGAGGATCCTTTTTTTTTTTTTTTTT-3') and SuperScript II RNase $\mathrm{H}^{-}$ reverse transcriptase (Invitrogen). After cDNA synthesis, RNA was digested with RNase A, and the unincorporated primer was eliminated using a Sephadex G-50 mini spin column (Worthington). cDNA containing the $3^{\prime}$-ends of 20 S RNA positive strands was PCR-amplified for 30 cycles using Taq polymerase (Promega) and primers RE157 (5' GACTCGAGTCGAGGATCC-3') and PG6 (5' -CGAATCGTCGCCAGTAG-3'). For amplification of the negative strand $3^{\prime}$-ends, we used oligonucleotide RE157 and oligonucleotide RE233 (5' -GCGTCGAAAGACGACAGC-3'). The amplified products from positive strand 3 '-ends were digested with HindIII and BamHI and ligated into the pBluescript $\mathrm{KS}^{+}$vector. In the case of negative strand $3^{\prime}$-ends, PCR products were digested with SalI and BamHI and ligated into the pBluescript $\mathrm{KS}^{+}$vector.

\section{RESULTS}

20 S and 23 S RNA Viruses Are Independent Replicons-23 S RNA virus can be generated in vivo from an expression plasmid containing the entire viral cDNA sequence. We wished to establish a similar launching system for $20 \mathrm{~S}$ RNA virus to carry out reverse genetics. However, most laboratory strains harbor 20 S RNA virus. During the course of 23 S RNA virus-launching experiments, we happened to obtain cells that had lost endogenous 20 S RNA virus. Strain 2928 L-A-o was transformed with the standard 23 S RNA-launching plasmid pRE637 (16). When transformants were analyzed, all of them generated 23 S RNA virus from the plasmid, and one of them (transformant 1) had apparently lost its endogenous 20 S RNA virus (Fig. $1 A$ ). We eliminated the launching plasmid from transformant 1 by isolating single colonies on nonselective YPAD agar plates. When the plasmid-cured colonies were analyzed, we found two types of segregants; the majority of colonies (10 of 12) contained only 23 S RNA virus generated from the plasmid, and the rest harbored neither $20 \mathrm{~S}$ nor $23 \mathrm{~S}$ RNA virus. Both types of segregants retained the genetic markers of the original strain. The segregants carrying 23 S RNA virus maintained the virus stably and did not produce virus-free colonies anymore. This suggests that the loss of endogenous 20 S RNA virus preceded the generation of 23 S RNA virus from the launching plasmid.

We confirmed the curing of 20 S RNA virus in these segregants by three criteria. First, we did not detect 20 S RNA by Northern blotting (Fig. $1 B$ ). Even when the gels were overloaded, we found no signal for 20 S RNA. The conditions used should have allowed us to detect 20 S RNA if the virus were present at as low as one copy/cell. Second, we could not amplify 20 S RNA cDNA from the lysates of these cells by RT-PCR (data not shown). Finally, as will be shown below, we could generate 20 S RNA virus tagged with a silent mutation from a launching plasmid using these 20 S RNA-negative segregants as hosts. We confirmed that the virus retained the mutation and was not the result of amplification of any residual endogenous 20 S RNA virus. Generated 20 S RNA virus could be maintained stably and was also induced normally under nitrogen starvation conditions in these cells. Therefore, the 20 S RNA-negative segregants have no genetic defects to harbor $20 \mathrm{~S}$ RNA virus. We designated segregants 4 and 5 shown in Fig. $1 B$ as 2928-4 and 2928-5, respectively. These segregants showed the same doubling time as the original strain, and we noticed no phenotypic changes in them. Strain 2928-5 carries only 23 S RNA virus derived from plasmid pRE637, but no 20 S RNA virus. Strain 2928-4 harbors none of the narnaviruses and can be used successfully as a host to generate 23 S RNA virus from the 23 

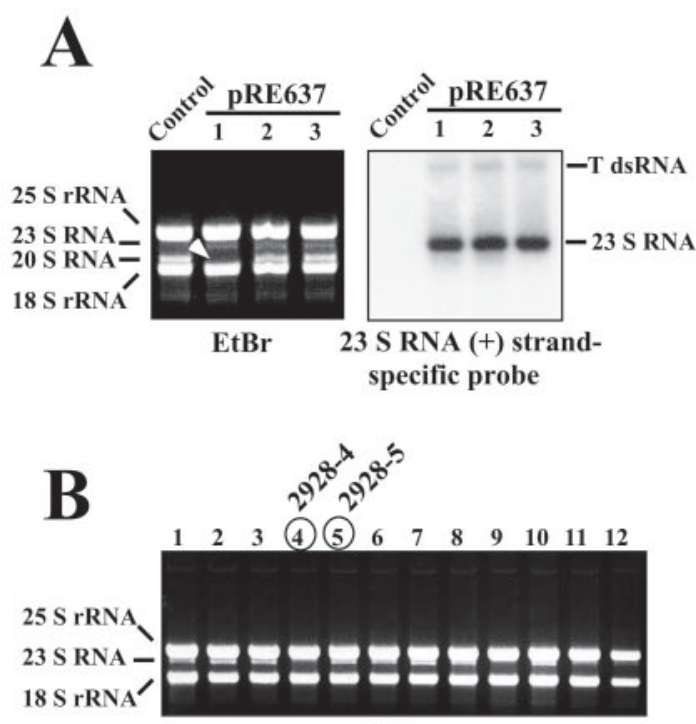

EtBr
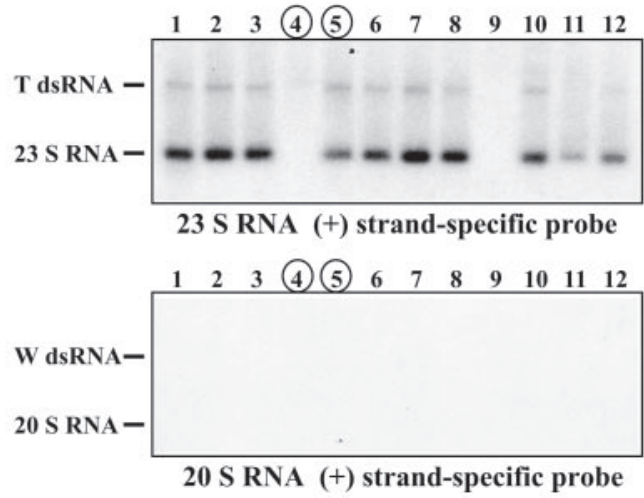

FIGURE 1. Curing of 20 S RNA virus by a 23 S RNA virus-launching plasmid. $A$, cells were transformed with the 23 S RNA virus-launching plasmid pRE637. RNA was extracted from transformants (lanes 1-3) and also from untransformed cells (Control lanes) and separated on an agarose gel. The RNA was blotted onto a nylon membrane, and positive strands of $23 \mathrm{~S}$ RNA on the membrane were detected by hybridization with a specific probe (right panel). Ethidium bromide staining of the gel is also shown (left panel). The positions of rRNAs, $20 \mathrm{~S}$ and $23 \mathrm{~S} \mathrm{RNAs}$, and T double-stranded RNA (dsRNA) are indicated. The arrowhead shows RNA from transformant 1 that had lost 20 S RNA virus during transformation. $B$, single colonies were isolated by streaking transformant 1 shown in $A$ on a nonselective agar plate. Twelve colonies (lanes 1-12) that had lost the plasmid were picked up. RNA was extracted from them and analyzed as described for $A$. Ethidium bromide staining of the gel (upper panel) and Northern blots analyzed with 23 S RNA (middle panel)- and 20 S RNA (lower panel)-specific probes are shown. Segregants 4 and 5 were designated 2928-4 and 2928-5, respectively (circled). Strain 2928-4 has none of the narnaviruses, and 2928-5 harbors only 23 S RNA virus generated from the launching plasmid. They were used throughout this work.

S RNA-launching plasmid (17). Although it has been reported that some industrial yeast strains (Saccharomyces diastaticus) appear to harbor only 23 S RNA-like molecules (24), these results are the first conclusive evidence that $23 \mathrm{~S}$ RNA virus does not require $20 \mathrm{~S}$ RNA virus for replication. Therefore, $20 \mathrm{~S}$ and $23 \mathrm{~S}$ RNA viruses are independent replicons.

Launching of 20 S RNA Virus from Expression Plasmids-We constructed a launching plasmid (pRE740) to generate 20 S RNA virus in yeast by inserting the entire $20 \mathrm{~S}$ RNA cDNA sequence (2514 bp) downstream of the constitutive $P G K 1$ promoter (Fig. $2 A$ ). Positive strands of $20 \mathrm{~S}$ RNA can be transcribed from the promoter. To generate transcripts in vivo with the precise viral 3 ' -end sequence at the 3 ' termini, an 82-nucleotide HDV antigenomic ribozyme cDNA sequence (25) was directly fused to the $3^{\prime}$-end of the 20 S RNA sequence. The plasmid has
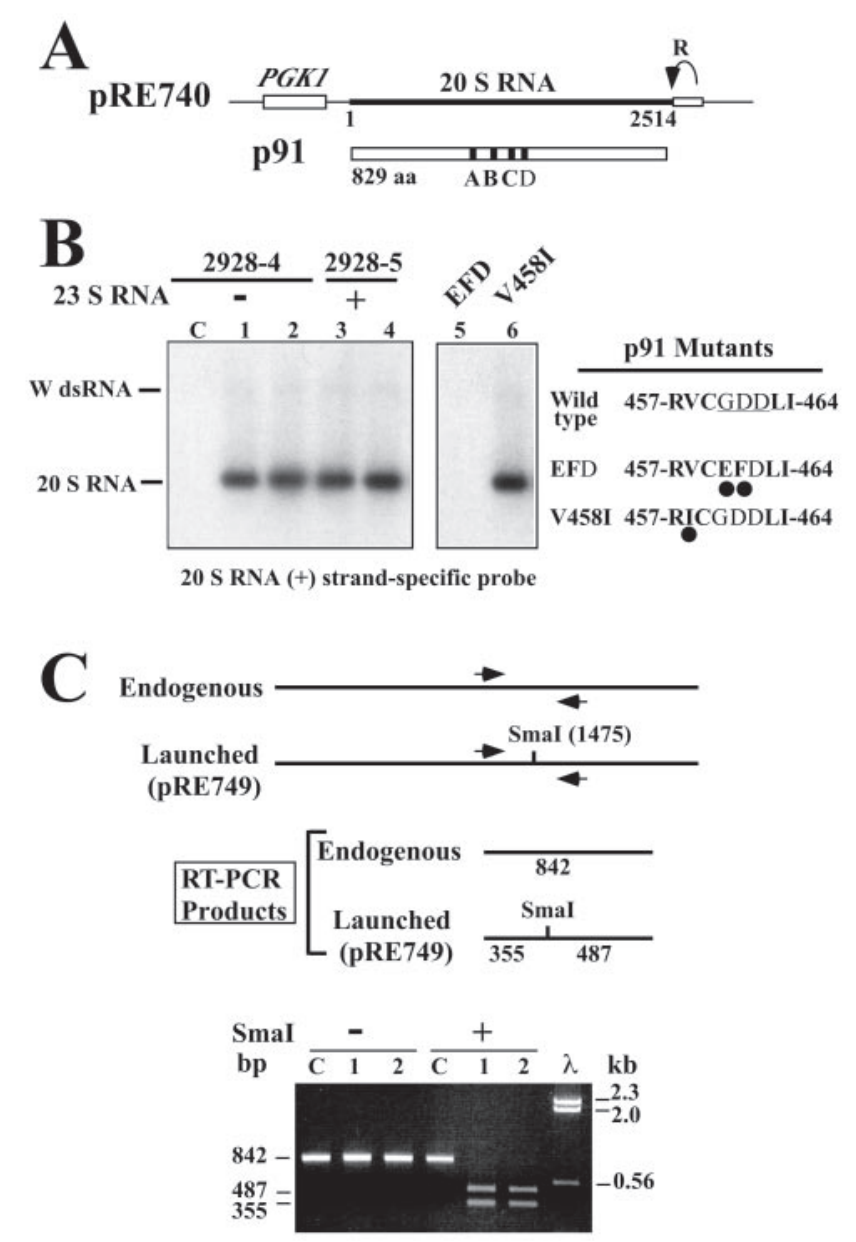

FIGURE 2. Generation of 20 S RNA virus in vivo from positive strands. $A$, the standard 20 S RNA-launching plasmid pRE740 contains the complete 20 S RNA CDNA sequence (bold line) downstream of the PGK1 promoter. Transcripts from the promoter have the positive polarity of the viral genome. The HDV antigenomic ribozyme $(R)$ and its cleavage site (curved arrow) and $\mathrm{p} 91$ and its conserved RNA-dependent RNA polymerase motifs $(A-D)$ are shown. aa, amino acids. $B$, shown is the generation of 20 S RNA from the launching plasmid. Strains 2928-4 (lanes 1 and 2) and 2928-5 (lanes 3 and 4) were transformed with the standard launching plasmid pRE740. Strain 2928-4 was also transformed with launching plasmids in which the amino acid sequence of p91 was modified (lanes 5 and 6) as indicated in the diagrams. RNA was extracted from transformed cells (lanes 1-6) or untransformed 2928-4 cells (lane C (control)) and analyzed by Northern blotting using a 20 S RNA positive strand-specific probe. dsRNA, double-stranded RNA. C, proof that 20 S RNA virus was generated from the launching plasmid is shown. A unique Smal site was created by a silent mutation $\left(1476 \mathrm{~T} \rightarrow \mathrm{G}\right.$, numbered from the $5^{\prime}$-end of the positive strand) of the viral genome in the launching plasmid. Strains 2928-4 (lanes 1) and 2928-5 (lanes 2) were transformed with the modified plasmid (pRE749). After virus generation, the plasmid was cured from the cells. RNA was prepared from these cells or from cells harboring endogenous 20 S RNA virus (lanes C). Then, an 842-bp cDNA fragment encompassing the Smal site was generated by RT-PCR. The products with $(+)$ and without $(-)$ Smal treatment were separated on an agarose gel and visualized by ethidium bromide staining. $\lambda$ Hindlll-digested markers and the positions of undigested or Smaltreated PCR products are indicated. The diagram shows endogenous and plasmid-generated 20 S RNAs and the expected sizes of their RT-PCR products. Arrows show the oligonucleotides primers used for amplification.

the TRP1 gene as a selectable marker. We transformed strains 2928-4 and 2928-5 with pRE740. Transformants were transferred to $1 \%$ potassium acetate to induce $20 \mathrm{~S}$ RNA, and the RNA was extracted from the induced cells. By Northern hybridization, we detected single-stranded 20 S RNA positive strands in all of the transformants. The amounts of positive strands among them were similar (Fig. 2B, lanes 1-4). We also found small amounts of W, the double-stranded form of 20 S RNA, in all transformants. Furthermore, we detected single-stranded 20 S RNA negative strands with a negative strand-specific probe (data not shown). 
These results indicate that $20 \mathrm{~S}$ RNA negative strands are synthesized from the positive strand transcripts in vivo and suggest the generation of 20 S RNA virus from the plasmid. To confirm this, we took two experimental approaches. First, we cured the plasmid from the transformants by isolating single colonies in nonselective YPAD agar plates. More than $70 \%$ of the plasmid-cured colonies retained 20 S RNA virus. Once generated, the virus replicated autonomously and could be maintained stably in the cells for $>100$ generations (so far examined) in the absence of the plasmid. The generated virus could be induced under nitrogen starvation conditions, and the viral RNA could be seen directly by ethidium bromide staining on agarose gels. The amount of induced RNA and the positive/negative strand ratios were similar to those found in endogenous 20 S RNA virus. We did not notice any effect of $23 \mathrm{~S}$ RNA virus on the efficiency of $20 \mathrm{~S}$ RNA virus generation (Fig. 2B, compare lanes 1 and 2 with lanes 3 and 4). Second, we introduced a unique SmaI site into the $20 \mathrm{~S}$ RNA cDNA sequence in pRE740 by changing the $\mathrm{T}$ at position 1476 to $\mathrm{G}$ (numbered from the $20 \mathrm{~S}$ RNA 5 ' -end) (Fig. 2C). This marking did not alter the amino acid sequence of the encoded $\mathrm{p} 91$ protein. We transformed strains 2928-4 and 2928-5 with the SmaI-tagged plasmid. Transformants from both strains generated 20 S RNA virus. After curing the plasmid, RNA was extracted from both strains, and an 842-bp 20 S RNA cDNA fragment encompassing the SmaI site was amplified by RT-PCR. We also amplified the 842-bp fragment from endogenous 20 S RNA virus present in the original $2928 \mathrm{~L}-\mathrm{A}$-o strain as a control. As shown in Fig. $2 C$ (lower panel), the amplified cDNA fragment from generated 20 S RNA virus in strain 2928-4 (lane 1) or 2928-5 (lane 2) was completely digested with SmaI, whereas the control from endogenous 20 S RNA virus was fully resistant to the enzyme (lane C). Therefore, these results demonstrate that 20 S RNA virus was generated from the launching plasmid and also confirm that the host strains 2928-4 and 2928-5 do not carry any endogenous 20 S RNA virus.

p91 Is Essential-20 S RNA encodes a single protein, p91. p91 has the four amino acid motifs well conserved among RNA-dependent RNA polymerases. When one of the motifs $\left({ }^{460} \mathrm{GDD}^{462}\right)$ was changed to ${ }^{460} \mathrm{EFD}^{462}$ in the launching plasmid, the modified vector failed to produce $20 \mathrm{~S}$ RNA virus (Fig. $2 B$, lane 5), indicating that active p91 is essential for replication. The presence of $23 \mathrm{~S}$ RNA virus in the host could not rescue the modified plasmid to generate 20 S RNA virus (data not shown). This indicates that p104 encoded by 23 S RNA cannot substitute p91 for replication of $20 \mathrm{~S}$ RNA virus and is consistent with the fact that $20 \mathrm{~S}$ and $23 \mathrm{~S}$ RNA viruses are independent replicons. p91 and p104 share an eight-amino acid sequence (R(V/I)CGDDLI) surrounding the GDD motif with only one mismatch. When the mismatched amino acid $\left(\mathrm{Val}^{458}\right)$ in $\mathrm{p} 91$ was replaced with Ile, thus making the stretch identical to the one found in p104, the plasmid with the modified p91 sequence produced $20 \mathrm{~S}$ RNA virus without any deleterious effects (Fig. 2B, lane 6). Previously, we found that $23 \mathrm{~S}$ RNA virus can also tolerate the reverse modification (Ile to Val) in the eight-amino acid sequence in p104 (16).

A Cluster of Four Cs at the 3'-End of the Positive Strand Is Essential for Replication-The transcription termination site for the FLP gene of the $2 \mu$ plasmid is located $0.7 \mathrm{~kb}$ downstream of the $20 \mathrm{~S}$ RNA genome in the vector (26). When the ribozyme GGG sequence 3' to the cleavage site was substituted with AAA in the standard launching plasmid pRE740, the modified plasmid failed to generate $20 \mathrm{~S}$ RNA virus (data not shown). Therefore, it is important to generate transcripts in vivo with the precise viral $3^{\prime}$ termini for virus launching. $20 \mathrm{~S}$ RNA has fivenucleotide inverted repeats at both termini $\left(5^{\prime}\right.$-GGGGC ... GCCCC$\mathrm{OH})$. We examined the role of the $3^{\prime}$-terminal nucleotides of the $20 \mathrm{~S}$ RNA positive strand in replication by modifying each nucleotide with $\mathrm{A}$

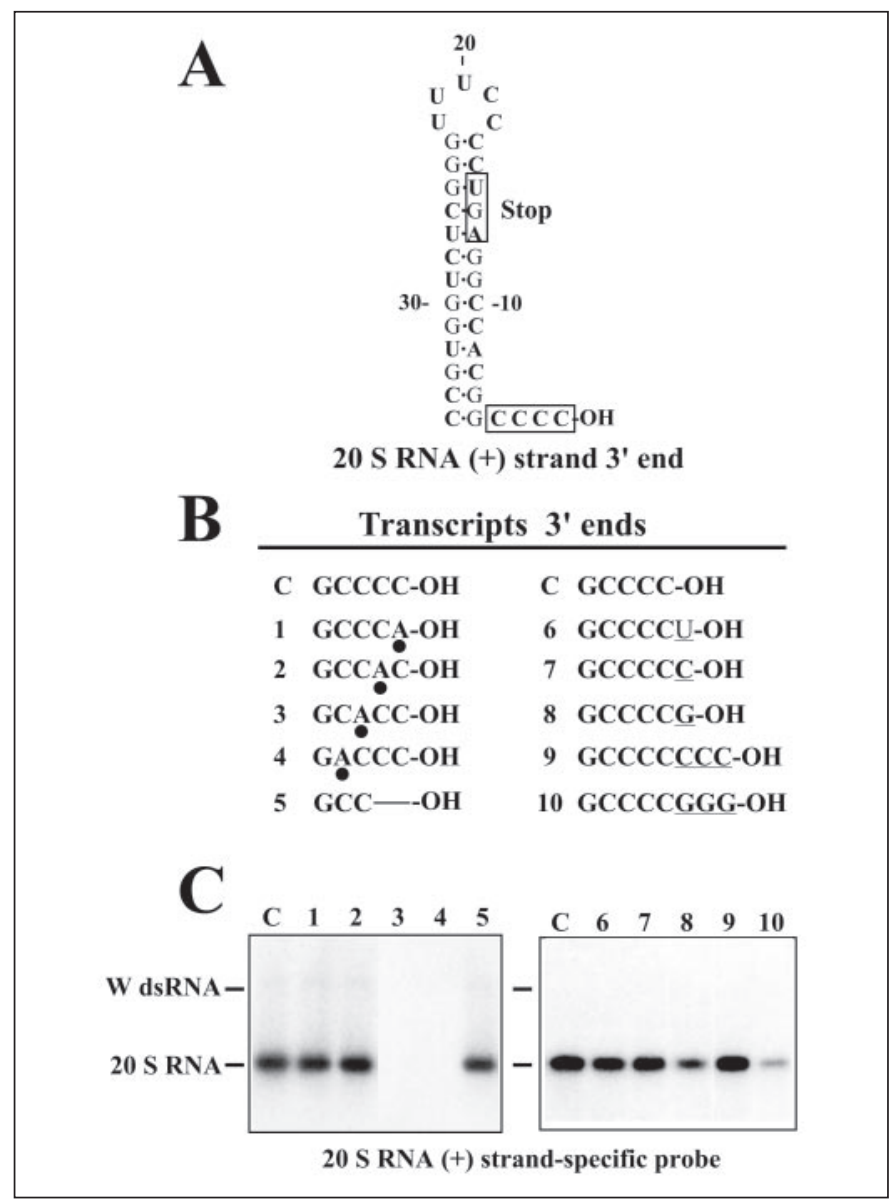

FIGURE 3. Effects of mutations at or the addition of extra nucleotides to the 3 '-end of the positive strand on virus generation. $A$, shown is a diagram of a secondary structure in the $3^{\prime}$-end region of the 20 SRNA positive strand. The stretch of four Cs at the $3^{\prime}$-end and the stop codon of p91 are boxed. Nucleotides are numbered from the 3 '-end. $B$, the standard launching plasmid was modified by a single mutation $(C$ to $A ;)$ introduced at each position in the row of four Cs (1-4) or by deletion $(-$ ) of the last two Cs from the $3^{\prime}$-end (5). The plasmid was also changed by the addition of a single nucleotide $(6-8)$ or three nucleotides ( 9 and 10 ) at the boundary between the $3^{\prime}$-end of the positive strand and the ribozyme cleavage site (underlined). The expected nucleotide sequences of the transcripts after cleavage by the ribozyme are shown. $C$ indicates the control without modification. C, cells (strain 2928-4) were transformed with the standard launching plasmid (lanes C (control)) or with plasmids modified as described for $B$ (lanes 1-10). RNA was extracted from transformants, and 20 S RNA was detected by Northern blotting as described in the legend to Fig. $1 A$ using a positive strand-specific probe. $d s R N A$, double-stranded RNA.

in the vector. As shown in Fig. 3, changing the 3 '-terminal or penultimate $\mathrm{C}$ did not affect the generation of 20 S RNA virus. On the contrary, a modification at the third or fourth $\mathrm{C}$ did not produce the virus. Therefore, the third and fourth Cs from the $3^{\prime}$-end are essential for replication. In good agreement, deletions of up to two Cs (but not three) generated 20 S RNA virus (Fig. 3) (data not shown). We were interested in the 3 '-terminal sequences of $20 \mathrm{~S}$ RNA viruses generated from these modified vectors. We cured the launching plasmids from the cells, and the viral RNAs were isolated. The 3 ' -terminal sequences of these RNAs were then amplified by $3^{\prime}$-RACE, and 8-10 independently isolated clones were sequenced. As shown in TABLE ONE, the substitution of the terminal (pRE757) or penultimate (pRE758) C with A at the viral 3 '-end was corrected to the wild-type $C$ in the generated viruses. Furthermore, viruses launched from 20 S RNA cDNA lacking two Cs at the 3 '-end (pRE759) recovered these nucleotides. Therefore, these results indicate that 20 S RNA virus, like 23 S RNA virus, has an efficient 3 ' -end repair mechanism(s) in vivo. The major transcription start site in the launching plasmid is located at position -42 , relative to the $5^{\prime}$ terminus 
3'-RACE: 3 '-ends of viral RNA generated from positive strand mutants

\begin{tabular}{|c|c|c|c|c|}
\hline Launching plasmid $^{a}$ & Clones & Positive strand $^{b}$ & Clones & Negative strand $^{b}$ \\
\hline pRE757 (...GCCCA-OH) & 8 & $\begin{array}{l}\text { 7...GCCCC-OH } \\
\text { 1...GCC-OH }\end{array}$ & 3 & 3...GCCCC-OH \\
\hline pRE758 (...GCCA-C-OH) & 8 & $\begin{array}{l}\text { 7...GCCCC-OH } \\
\text { 1...GCCCC(G)-OH }\end{array}$ & 3 & $\begin{array}{l}\text { 2...GCCCC-OH } \\
1 \ldots \text { GCCCC(G)-OH }\end{array}$ \\
\hline pRE759 (...GCC__-OH) & 8 & $\begin{array}{l}\text { 7...GCCCC-OH } \\
\text { 1...GCCCC(G)-OH }\end{array}$ & 2 & $\begin{array}{l}\text { 1...GCCCC-OH } \\
\text { 1...GCCCC(G)-OH }\end{array}$ \\
\hline pRE794 (...GCCCCL-OH) & 9 & $\begin{array}{l}\text { 7...GCCCC-OH } \\
1 \ldots \mathrm{GCCCC}(\mathrm{G})-\mathrm{OH} \\
1 \ldots \mathrm{GCCCC}(\mathrm{U})-\mathrm{OH}\end{array}$ & & $\mathrm{ND}^{c}$ \\
\hline pRE800 (...GCCCCG-OH) & 10 & $\begin{array}{l}\text { 7...GCCCC-OH } \\
1 \ldots \mathrm{GCCCC}(\mathrm{C})-\mathrm{OH} \\
2 \ldots \mathrm{GCC}-\mathrm{OH}\end{array}$ & & ND \\
\hline pRE795 (...GCCCCCCC-OH) & 10 & $\begin{array}{l}\text { 7...GCCCC-OH } \\
\text { 3...GCCC-OH }\end{array}$ & & ND \\
\hline pRE793 (...GCCCCGGG-OH) & 10 & $\begin{array}{l}8 \ldots \mathrm{GCCCC}-\mathrm{OH} \\
1 \ldots \mathrm{GCCCC}(\mathrm{G})-\mathrm{OH} \\
1 \ldots \mathrm{GCC}-\mathrm{OH}\end{array}$ & & ND \\
\hline \multicolumn{5}{|c|}{$\begin{array}{l}{ }^{a} \text { Modifications of or extra nucleotides added at the } 3^{\prime} \text {-end of the } 20 \mathrm{~S} \text { RNA posit } \\
{ }^{b} \text { Extra sequences found in the viral } 3^{\prime} \text {-ends cloned are indicated by parentheses. } \\
{ }^{c} \text { Not determined. }\end{array}$} \\
\hline
\end{tabular}

of the $20 \mathrm{~S}$ RNA genome. These extra nucleotides were not present in the generated viruses as judged from the 3 '-sequences of the negative strands (TABLE ONE). We also added extra nucleotides between the 3 '-end of $20 \mathrm{~S}$ RNA and the ribozyme sequence and examined their effects on virus launching. As shown in Fig. 3, the addition of a single $U$ (lane 6), C (lane 7), or A (data not shown) did not affect the generation of $20 \mathrm{~S}$ RNA virus. However, the addition of a single $\mathrm{G}$ reduced virus launching (lane 8). Likewise, the addition of three Gs (lane 10), but not three Cs (lane 9), severely affected 20 S RNA virus generation. Extra Gs at the 3 '-end reduced the efficiency of virus launching by severalfold as judged by counting virus-positive and virus-negative colonies after curing the plasmids. Once the plasmids were cured, however, the amount of $20 \mathrm{~S}$ RNA in the cells was similar to that generated from the wild-type cDNA without extra nucleotides at the $3^{\prime}$-end. We isolated viral RNA from plasmid-cured cells and analyzed the $3^{\prime}$-ends of the positive strands by $3^{\prime}$-RACE. As shown in TABLE ONE, the launched viruses examined eliminated the extra nucleotides present at the 3 ' -ends in the vectors. Therefore, these results clearly indicate that 20 S RNA virus has a mechanism(s) to correctly maintain the size and sequence of the $3^{\prime}$-end of the positive strand and is thus capable of repairing limited damage of the 3 '-end.

The Fifth G from the 3'-End in the Positive Strand Is Dispensable for Replication-When the fifth $\mathrm{G}$ from the $3^{\prime}$-end was changed to $\mathrm{C}$ $\left(5 \mathrm{G} \rightarrow \mathrm{C}\right.$, numbered from the $3^{\prime}$-end) in the vector, the modified plasmid failed to generate $20 \mathrm{~S}$ RNA virus (Fig. 4, lane 1), thus suggesting that this nucleotide is essential for replication. Alternatively, because the fifth $\mathrm{G}$ is part of a structure adjacent to the $3^{\prime}$-end, the inability of this plasmid to generate the virus may be a secondary effect due to a perturbation of the stem structure caused by the modification. Because the corresponding nucleotide in the $23 \mathrm{~S}$ RNA genome 3 ' -end is dispensable for its replication (17), we were interested in this result and tried to distinguish these two possibilities. To restore the stem structure in the $5 \mathrm{G} \rightarrow \mathrm{C}$ mutant, we introduced a second mutation, $35 \mathrm{C} \rightarrow \mathrm{G}$, at the other side of the stem (lane 3 ). Because this compensatory mutation resulted in the change of one amino acid ( $\mathrm{Thr}^{823}$ to Ser) at the C terminus of p91, we made two more constructs as controls. One construct contained the single mutation $36 \mathrm{~A} \rightarrow \mathrm{U}$ with the wild-type stem and wild-type ... GCCCC-OH terminus and, as shown in lane 4, produced 20 S RNA virus. Thus, p91 can tolerate the amino acid change T823S for its activities. The second control contained the single mutation $35 \mathrm{C} \rightarrow \mathrm{G}$ with the wild-type ... GCCCC-OH terminus. This construct, as shown in lane 2, failed to generate $20 \mathrm{~S}$ RNA virus. Therefore, these control experiments suggest that the fifth nucleotide needs to be hydrogenbonded. Consistently, the compensatory mutation $35 \mathrm{C} \rightarrow \mathrm{G}$ restored the ability to generate virus on the $5 \mathrm{G} \rightarrow \mathrm{C}$ mutant (lane 3 ). This result clearly indicates that, as in the case of 23 S RNA virus, the fifth G in $20 \mathrm{~S}$ RNA virus is dispensable for replication. To rule out the possibility that this double mutant generated replicable revertants during launching, we isolated viral RNA after curing the plasmid and determined the 3 '-terminal sequences by $3{ }^{\prime}$-RACE. We sequenced 17 independently isolated clones. All of them retained the compensatory mutation $35 \mathrm{C} \rightarrow \mathrm{G}$ at the $5^{\prime}$-side of the stem. Of these 17,11 clones had the full $3^{\prime}$-terminal sequence ( . . GCCCCC-OH), and the rest possessed the $3^{\prime}$ termini truncated by one nucleotide ( . . GCCCC_-OH; four clones) or by two nucleotides (...GCCC_-OH; two clones). Therefore, these results show that no revertants were generated during virus launching. Furthermore, as the majority (11 of 17 ) retained the full $3^{\prime}$-terminal sequence, the sixth $\mathrm{G}$ from the $3^{\prime}$-end did not substitute for the modified nucleotide at position 5 in replication.

Launching of 20 S RNA Virus from Negative Strands-We also tried to generate 20 S RNA virus from negative strands. Plasmid pRE805 (the template plasmid) has the complete sequence of 20 S RNA downstream of the PGK1 promoter (Fig. 5A). The orientation of the cDNA was reversed so that transcripts from the promoter would have the negative strand polarity of the viral genome. The HDV antigenomic ribozyme was directly fused to the 3 ' -end of the viral negative strand. When virusfree strain 2928-4 was transformed with pRE805, we found no generation of $20 \mathrm{~S}$ RNA virus from the plasmid (Fig. 5C). This was expected because $\mathrm{p} 91$ cannot be translated from the negative strands transcribed from the PGK1 promoter. Plasmid pRE787 (the polymerase plasmid) is the standard launching plasmid, but with the mutation $4 \mathrm{C} \rightarrow \mathrm{A}$ in the 3 '-cis-signal in the positive strand. Although wild-type p91 could be translated from the transcripts, this plasmid could not generate $20 \mathrm{~S}$ RNA virus because of this mutation (Fig. 3C, lane 4). When yeast cells were transformed with both plasmids, the transformants could generate $20 \mathrm{~S}$ RNA virus (Fig. 5B). The efficiency of virus generation was high. After curing the plasmids, $>70 \%$ of the plasmid-free colonies generated the virus, an efficiency similar to that of the standard launching plasmid 
FIGURE 4. The fifth $\mathrm{G}$ from the 3 '-end in the $20 \mathrm{~S}$ RNA positive strand is not essential for replication. $A$, cells were transformed with the standard launching plasmid (lane C (control)) or with launching plasmids modified as described for $B$ (lanes 1-4). RNA was extracted from transformants, and $20 \mathrm{~S}$ RNA was detected by Northern blotting as described in the legend to Fig. $1 A$ using a positive strand-specific probe. $d s R N A$, doublestranded RNA. B, mutations (-) were introduced at positions 5, 35, and 36 (numbered from the 3 '-end of the 20 S RNA genome) in the standard launching plasmid. The expected secondary structure and nucleotide sequence at the 3 '-ends of the transcripts for each construct (after ribozyme cleavage) are shown. Codon 823 of p91 is boxed, and the corresponding amino acid is shown. $C$ indicates the wild-type control.

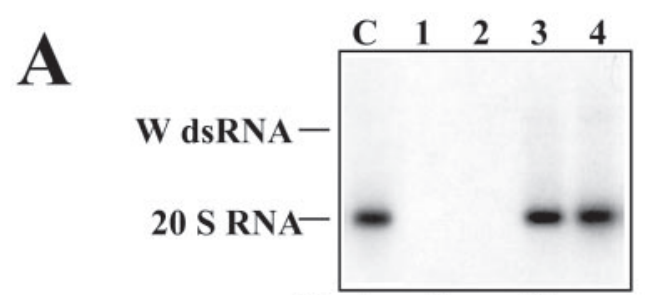

$(+)$ strand-specific probe

B

Transcripts 3' ends

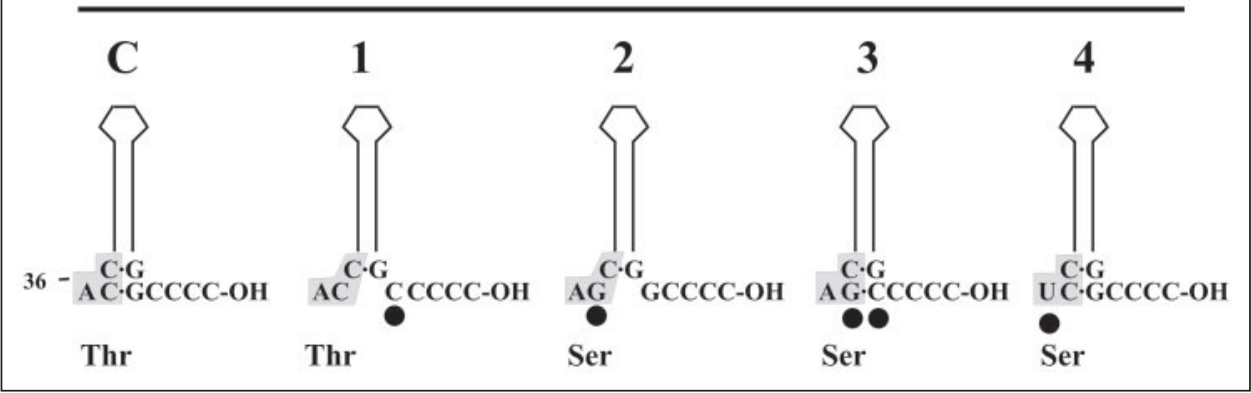

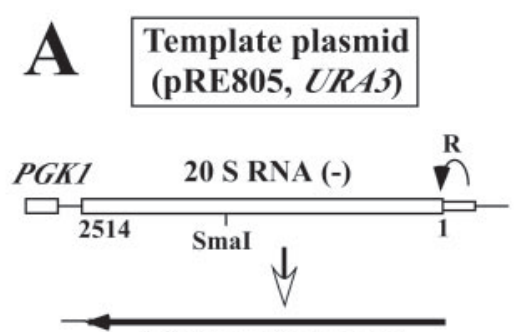

(-) strand transcript
Polymerase plasmid (pRE787, TRPI)

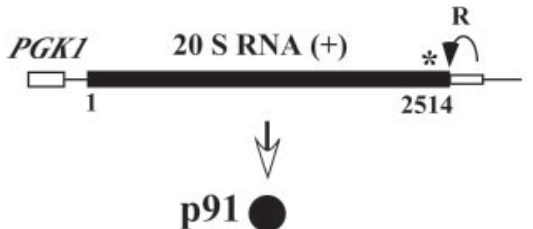

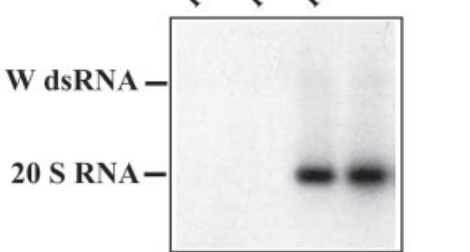

(+) strand-specific probe
RT-PCR of launched virus

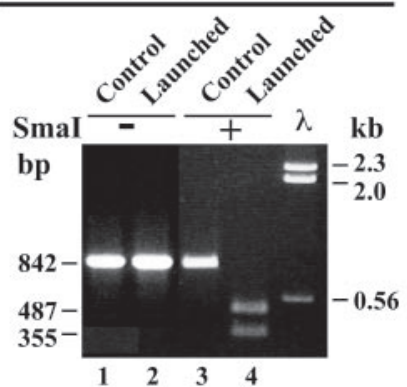

FIGURE 5. Generation of 20 S RNA virus from negative strands in a two-vector system. $A$, the template plasmid (pRE805) has URA 3 as a selective marker and contains the entire 20 S RNA cDNA sequence downstream of the PGK1 promoter. The orientation of 20 S RNA is reversed so that the negative strand of the viral genome can be transcribed from the promoter. The viral genome was tagged by a silent mutation ( $1476 \mathrm{~T} \rightarrow \mathrm{G}$, numbered from the $5^{\prime}$-end of the positive strand) to create a unique Smal site. The HDV antigenomic ribozyme $(R)$ is directly fused to the $3^{\prime}$-end of the negative strand. The polymerase plasmid (pRE787) has a TRP1 selective marker and is a derivative of the standard launching plasmid pRE740 with a 4C $\rightarrow$ A mutation at the $3^{\prime}$-end of the positive strand genome (indicated by the asterisk). Transcripts from this plasmid can be translated into wild-type p91 but could not generate 20 S RNA virus because of the $4 C \rightarrow A$ mutation (see Fig. 3C, lane 4). The 20 S RNA genome in the polymerase plasmid has no Smal site. B, cells were transformed with either the template plasmid (pRE805) or the polymerase plasmid (pRE787) alone or together. As a control, cells were also transformed with the standard launching plasmid pRE740. RNA was extracted from transformants, and 20 S RNA was detected by Northern blotting using a positive strand-specific probe as described in the legend to Fig. 1A. dsRNA, double-stranded RNA. C, proof that the virus was generated from negative strands is shown. RNA was prepared from 20 S RNA-generated cells from which both plasmids had been cured, and an 842-bp cDNA fragment encompassing the Smal site was obtained by RT-PCR (lanes 2 and 4). As a control, we also amplified the cDNA fragment from RNA extracted from 2928 L-A-o cells carrying its endogenous 20 S RNA virus (Ianes 1 and 3). The cDNA fragments, either undigested (Ianes 1 and 2) or digested with Smal (Ianes 3 and 4), were separated on an agarose gel. Ethidium bromide staining of the gel is shown. 
Launching of 20 S RNA Virus from Positive/Negative Strands

A

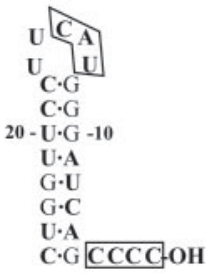

20 S RNA (-) strand 3' end

B

(-) strand transcripts 3 ' ends

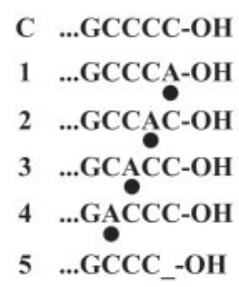

C
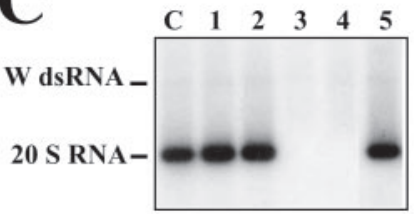

(+) strand-specific probe
FIGURE 6. Effects of mutations at the $3^{\prime}$-end of the negative strand on virus generation. $A$, shown are the nucleotide sequence of the last 25 nucleotides of the $3^{\prime}$-end region of the 20 S RNA negative strand and its predicted secondary structure. The row of four Cs at the 3 '-end and the three nucleotides complementary to the initiation codon of p91 are boxed. $B$, the mutations introduced in the template plasmid are shown. Each $C$ in the row of four $C s$ at the $3^{\prime}$-end was changed to $A(-)(1-4)$. A single $C$ was also deleted $(1)$ from the $3^{\prime}$-end (5). The diagrams show the expected 3 '-end sequences of the transcripts generated after ribozyme cleavage. $C$ indicates the wild-type control. $C$, cells containing the polymerase plasmid (lane $C$ ) were transformed with the template plasmids (lanes 1-5) modified as described for B. RNA was isolated from transformants, and 20 S RNA was detected by Northern blotting as described in the legend to Fig. $1 A$ using a positive strand-specific probe. $d s R N A$, double-stranded RNA.

pRE740 with positive strand transcripts. We interpreted this result as follows. The primary transcripts from the template plasmid were processed by ribozyme cleavage in cis to produce negative strand templates with the correct viral $3{ }^{\prime}$-ends. p91 produced from the polymerase plasmid acted in trans to produce positive strand copies from the negative strand templates. A positive or negative strand viral RNA with the correct $5^{\prime}$ - and $3^{\prime}$-ends was generated from the positive strand copies or negative strand templates by a mechanism(s) yet to be identified. Once generated, it was amplified by p91, thus creating a new virus. To confirm this interpretation, we did three experiments. First, when the ribozyme sequence in the template plasmid was modified (substitution of the GGG sequence 3' -end to the cleavage site with AAA), thus destroying its cleavage activity (16), the launching activity was abolished (data not shown). This indicates the importance of creating negative strands with the correct viral $3^{\prime}$-ends for virus launching in this two-vector system. Second, we introduced a mutation (EFD) of the GDD motif of p91 into the polymerase plasmid. The modified plasmid failed to generate $20 \mathrm{~S}$ RNA virus in this two-vector system (data not shown). This indicates that active p91 from the polymerase plasmid is essential for virus generation. Finally, we confirmed that the virus originated from the template plasmid (pRE805). The $20 \mathrm{~S}$ RNA genome in pRE805 was tagged with a unique SmaI site by a silent mutation $(1476 \mathrm{~T} \rightarrow \mathrm{G}$, numbered from the 5 '-end of the positive strand), whereas the viral genome in the polymerase plasmid (pRE787) had no SmaI sites. From RNA isolated from the plasmid-cured cells, we amplified a cDNA fragment of $842 \mathrm{bp}$ encompassing the SmaI site by RT-PCR. We also amplified the corresponding fragment from endogenous $20 \mathrm{~S}$ RNA virus as a control. When these fragments were digested with SmaI (Fig. 5C), the cDNA from the launched virus was digested completely, whereas the cDNA from the endogenous virus was totally resistant to the enzyme. Therefore, these results demonstrate that the virus was derived from the negative strands transcribed from the template plasmid (pRE805).

Using this two-vector system, we examined the role of the $3^{\prime}$-terminal four $\mathrm{Cs}$ of the negative strand in viral replication. We introduced a single mutation ( $\mathrm{C}$ to $\mathrm{A}$ ) at each position in the row of four $\mathrm{Cs}$ in the template plasmid. As shown in Fig. 6, the mutation at the third or fourth $\mathrm{C}$ from the $3^{\prime}$-end abolished the generation of 20 S RNA virus, whereas changing the $3^{\prime}$-terminal or penultimate $\mathrm{C}$ to $\mathrm{A}$ did not affect the generation of $20 \mathrm{~S}$ RNA virus. Consistently, up to two Cs could be eliminated from the 3 '-end in the vector without any effects on virus generation (Fig. 6) (data not shown). These results indicate that the third and fourth Cs from the $3^{\prime}$-end of the negative strand are essential for $20 \mathrm{~S}$ RNA virus replication, whereas the $3^{\prime}$-terminal or penultimate $C$ is dispensable for virus launching. We isolated viral RNAs from plasmidcured cells and determined their $3^{\prime}$-end sequences by $3{ }^{\prime}$-RACE (TABLE TWO). A mutation at the penultimate $\mathrm{C}$ (pLOR-2) or deletion of the $3^{\prime}$-terminal nucleotide (pLOR-4) introduced into the vector was corrected to the wild-type $\mathrm{C}$ in the generated viruses. Therefore, the cluster of four $\mathrm{Cs}$ at the 3 '-end of the negative strand is again a $3^{\prime}$-cis-signal for replication (or part of it), and the virus also has a repair mechanism(s) to correctly maintain this $3^{\prime}$-end. Interestingly, we observed that negative strands cloned after $3^{\prime}$-RACE possessed an extra $\mathrm{G}$ at the $3^{\prime}$-ends at high frequencies $(50 \%$ in some cases). Positive strands cloned from the same RNA preparations had an extra $\mathrm{G}$ at the $3^{\prime}$-ends but at much lower frequencies. At present, we do not know the biological significance of this observation.

\section{DISCUSSION}

In this work, we have described the generation of 20 S RNA virus from a vector by expressing the viral RNA in vivo. The RNA can be either the positive or negative strand of the $20 \mathrm{~S}$ RNA genome. In the latter case, active p91 needs to be provided in trans from a second vector. Once 20 $\mathrm{S}$ RNA virus is generated, however, the virus does not require these vectors any longer and can be propagated autonomously. Because $20 \mathrm{~S}$ RNA virus does not confer any phenotypic changes on the host, it has been impossible to perform comprehensive genetic analysis on this virus. Therefore, these launching systems have allowed us to carry out reverse genetics to determine and analyze cis-acting signals necessary for replication present not only in the positive strand but also in the negative strand of the viral genome.

Host Strains - During the course of experiments launching 23 S RNA virus from a vector, we happened to obtain 20 S RNA-cured cells. Interference in viral replication by defective interfering particles or by other viruses is well known among DNA and RNA viruses. In yeast, L-A and L-BC double-stranded RNA viruses can be eliminated from the cells by transcribing L-A and L-BC positive strand RNAs, respectively, from a vector $(27,28)$. Although $20 \mathrm{~S}$ and $23 \mathrm{~S}$ RNA viruses are compatible in the same host and do not exclude each other, their copy numbers in logarithmically growing cells are extremely low compared with those under induction conditions (nitrogen starvation). Therefore, overexpression of 23 S RNA or its gene product (p104) from a vector in growing cells may have taken up a hypothetical limiting cellular factor shared by $20 \mathrm{~S}$ and $23 \mathrm{~S}$ RNA viruses necessary for replication or for stable transmission to daughter cells. We have not yet determined the frequency of exclusion, but it appears to be quite low. 
3'-RACE: 3 '-ends of viral RNA generated from negative strand mutants

\begin{tabular}{|c|c|c|c|c|}
\hline Template plasmid $^{a}$ & Clones & Negative strand $^{b}$ & Clones & Positive strand $^{b}$ \\
\hline pLOR2 (...GCCA & 7 & $\begin{array}{l}\text { 3...GCCCC-OH } \\
\text { 3...GCCCC(G)-OH } \\
\text { 1...GC-OH }\end{array}$ & 6 & $\begin{array}{l}\text { 4...GCCCC-OH } \\
\text { 1...GCCCC(G)-OH } \\
\text { 1...GCCC-OH }\end{array}$ \\
\hline pLOR4 (...GCCC_-OH) & 12 & $\begin{array}{l}\text { 6...GCCCC-OH } \\
6 \ldots \mathrm{GCCCC}(\mathrm{G})-\mathrm{OH}\end{array}$ & 10 & $\begin{array}{l}\text { 7...GCCCC-OH } \\
\text { 2...GCCCC(G)-OH } \\
\text { 1...GCCC-OH }\end{array}$ \\
\hline
\end{tabular}

${ }^{a}$ Modifications introduced at the 3 '-end of the 20 S RNA negative strand in the template plasmid are underlined.

${ }^{b}$ Extra sequences found in the viral $3{ }^{\prime}$-ends cloned are indicated in parentheses.

p91 Is Essential-When the GDD sequence in p91 was changed to EFD in the vector, the modified launching plasmid failed to generate 20 S RNA virus. Crystallographic studies have demonstrated that RNA-dependent RNA polymerases of RNA viruses, like DNA-dependent DNA or RNA polymerases or reverse transcriptases, form tertiary structures resembling a right hand (29-31). The four amino acid motifs well conserved among RNA-dependent RNA polymerases, including the GDD motif, are located within a subdomain called the palm. The first aspartic acid residue of the GDD motif coordinates two $\mathrm{Mg}^{2+}$ ions, which are essential for the catalytic activity in polymerization. Therefore, the failure of the EFD mutant to generate 20 S RNA virus is due to destruction of the catalytic site of RNA polymerization in p91. Short stretches of amino acids flanking the GDD motif form a $\beta$-hairpin structure with GDD in the hairpin loop. p91 and p104 polymerases share the same eight-amino acid sequence (R(V/I)CGDDLI) surrounding the GDD motif with one mismatch. When the mismatched Val in p91 was changed to Ile, thus making the eight-amino acid stretch identical to the one in p104, p91 tolerated this change, and 20 S RNA virus was generated from the modified vector. Previously, we found that 23 S RNA virus also tolerates the reverse change (Ile to Val) in the same stretch in p104. (16). Because these aliphatic amino acids are favored for $\beta$-sheet formation, these exchanges apparently do not significantly affect the overall structure of each polymerase. These results indicate the potential usefulness of the launching systems of $20 \mathrm{~S}$ and $23 \mathrm{~S}$ RNA viruses for structure-function analysis of these polymerases. Furthermore, as p91 and p104 also form ribonucleoprotein complexes with their cognate viral RNAs, these launching systems will be powerful tools for assigning and analyzing domains with distinct functions in these polymerases.

Positive Strand 3'-cis-Signal-In this work, we developed two launching systems to generate $20 \mathrm{~S}$ RNA virus in vivo: one from the genomic strands and the other from the antigenomic strands. The former system is similar to the one established previously to generate $23 \mathrm{~S}$ RNA virus (16). Using this launching system, we analyzed 3'-cis-signals for replication present in the $20 \mathrm{~S}$ RNA positive strand. $20 \mathrm{~S}$ and $23 \mathrm{~S}$ RNA viruses share the same five-nucleotide inverted repeats at both termini (5'-GGGGC ... GCCCC-OH). Our results indicate that the third and fourth Cs from the $3^{\prime}$-end of the positive strand are essential for replication, whereas the terminal and penultimate Cs are dispensable, at least for virus launching. In the latter cases, however, we found that the viruses regained the wild-type four Cs. Thus, 20 S RNA virus, like $23 \mathrm{~S}$ RNA virus, has an efficient repair mechanism(s) for the viral 3 '-ends, and the stretch of four Cs at the 3 ' -end of the 20 S RNA positive strand is essential for replication. In contrast to these terminal four Cs, the fifth $\mathrm{G}$ is not essential; however, it needs to be hydrogen-bonded with the nucleotide at the other side of the stem (Fig. 4). There are two probable explanations for this. $20 \mathrm{~S}$ and $23 \mathrm{~S}$ RNA viruses are closely related but independent replicons. Therefore, their replication machineries have to discriminate each other and recognize their own RNA template for replication. 23 S RNA virus has a bipartite 3 ' -cis-signal that

\section{S RNA 3' ENDS}

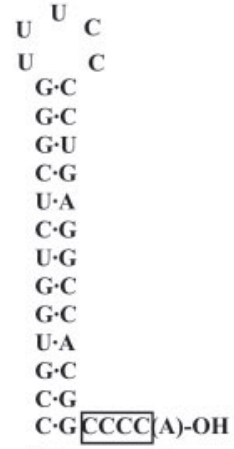

$(+)$ strand

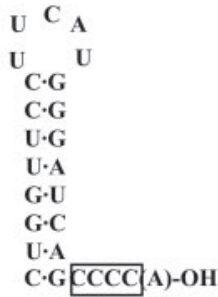

(-) strand

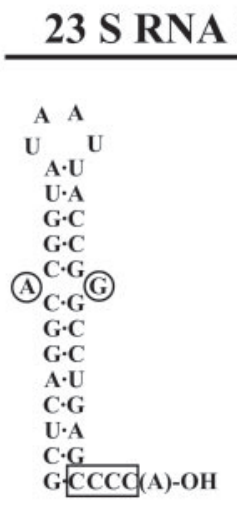

(+) strand

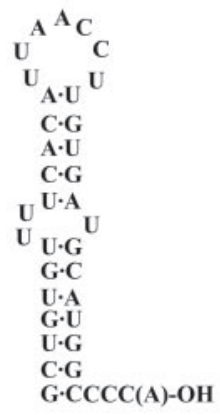

(-) strand
FIGURE 7. Comparison of the 3 '-terminal secondary structures in the positive and negative strands of $20 \mathrm{~S}$ and 23 S RNA viruses with the top half-domain of tRNA. The non-templated As at the viral $3^{\prime}$ termini are indicated by parentheses. The 3'-cis-acting signals for replication identified in this work present in the positive and negative strands of 20 S RNA virus are boxed. The bipartite 3 '-cis-signal present in the positive strands of 23 S RNA virus is also boxed and circled. The top half-domain of eukaryotic tRNATyr was derived from Sprinzl et al. (43). $Y, R$, and $N$ stand for pyrimidine, purine, and any base, respectively.

consists of a stretch of four Cs at the $3^{\prime}$-end and a mismatched pair of purines in a stem-loop structure adjacent to the $3^{\prime}$-end (Fig. 7). In $23 \mathrm{~S}$ RNA virus, the fourth $\mathrm{C}$ from the $3^{\prime}$-end is hydrogen-bonded and located at the lower edge of the stem structure. Therefore, the replication machinery of $20 \mathrm{~S}$ RNA virus may recognize a stretch of singlestranded four Cs at the $3^{\prime}$-end flanked by a stem structure at the $5^{\prime}$-side without a spacer as a cis-signal for replication. Alternatively, 20 S RNA virus may also have a bipartite $3^{\prime}$ - cis-signal with the second site yet to be located in the stem-loop structure adjacent to the $3^{\prime}$-end. Thus, elimination of the hydrogen bonding at the lower edge of the stem may alter 
the bipartite signal by shortening the distance between the two sites or changing their topological configuration. 23 S RNA virus did not tolerate a change of adding or eliminating 2 base pairs at the lower stem that separates both sites. ${ }^{5}$

Launching of 20 S RNA Virus from Antigenomic Strands-In the second launching system, we used two vectors to separately express the 20 $\mathrm{S}$ RNA antigenomic strands and the polymerase. Either vector alone could not generate the virus. However, when these two plasmids were introduced together into the same host, the cells generated 20 S RNA virus. That the virus was not generated by recombination between these two plasmids or between their transcripts is illustrated by the following evidence. First, transcripts from these two vectors had opposite polarities. Therefore, the 20 S RNA wild-type genome cannot be produced by recombination between them. Second, the high efficiency of virus generation (as efficient as that from a single vector expressing positive strands) suggests that the virus was not generated through rare events such as RNA-RNA recombination. Third, when the essential GDD motif of p91 in the polymerase plasmid was changed to EFD, the modified plasmid failed to assist virus generation. This indicates the importance of an active p91 protein rather than its DNA or RNA sequence in the polymerase plasmid for virus generation. Fourth, when the ribozyme GGG sequence 3' to the cleavage site was changed to AAA in the template plasmid, thus destroying its cleavage activity, the modified template plasmid failed to generate 20 S RNA virus. This indicates that the negative strand transcripts need to be processed by the ribozyme to produce correct 3 '-ends at the RNA termini. Finally, we found that the viruses retained the silent mutation $(1476 \mathrm{~T} \rightarrow \mathrm{G})$ tagged in the template plasmid. This indicates that their RNA genome derived from the negative strands transcribed from the template plasmid. This also eliminates the possibility that the $4 \mathrm{C} \rightarrow \mathrm{A}$ mutation in the polymerase plasmid was rescued by recombination between the two plasmids. Because the GDD motif and the silent mutation were separated by only 85 nucleotides in the viral genome, such recombination should also efficiently rescue the EFD mutation in the polymerase plasmid.

Using this two-vector system, we found that the third and fourth Cs from the 3 '-end of the negative strand are essential for replication. The 3 '-terminal and penultimate Cs were dispensable for virus launching; however, the generated viruses regained the wild-type Cs at these positions. Therefore, the cluster of four consecutive Cs at the $33^{\prime}$-end of the negative strand is again a $3^{\prime}$-cis-signal for replication or part of it.

3'-End Repair and Viral Persistence-20 S RNA virus can repair mutations introduced at the terminal or penultimate position from the 3 -end or deletion of up to two nucleotides from the 3 '-end in the positive or negative strand. Likewise, the addition of three extra Cs to the 3 '-end of the positive strand did not affect virus launching, and the virus generated possessed the wild-type termini without these extra nucleotides. Therefore, $20 \mathrm{~S}$ RNA virus has a mechanism(s) to maintain not only the correct sequence but also the correct length of the viral 3 '-ends. Interestingly, the addition of three extra Gs reduced the efficiency of virus generation, although the virus generated did not retain these extra Gs at the $3^{\prime}$-end. We observed previously that the addition of a row of eight Gs to the $5^{\prime}$-end of the 23 S RNA cDNA genome reduces the generation of $23 \mathrm{~S}$ RNA virus from a launching vector (16). However, the addition of eight Cs does not have such an effect. It is known that oligo $G$ tracts inhibit the progression of $5^{\prime}$ - and $3^{\prime}$-exonucleases in yeast $(32,33)$. This is thus consistent with the idea that the $5^{\prime}$ - and 3 '-non-viral sequences in the transcripts after ribozyme cleavage were eliminated by host exonucleases. The launching vectors expressing $20 \mathrm{~S}$

${ }^{5}$ R. Esteban, M. Ramírez-Garrastacho, and T. Fujimura, unpublished data.
RNA positive and negative strands contained non-viral sequences of 42 and 41 nucleotides, respectively, between the major transcription start site and the $5^{\prime}$-end of the viral genome. Although these extra sequences are almost 10 nucleotides longer than the one present in the 23 S RNAlaunching vector, we found that launching of 20 S RNA virus from these vectors was as efficient as (or better than) the generation of 23 S RNA virus observed previously. On the other hand, the addition of one or three extra Gs to the $3^{\prime}$-end greatly reduced the generation of 20 S RNA virus. These results correlate with the fact that the SKI1/XRN1 $5^{\prime}$-exonuclease is more active than the $3^{\prime}$-exonuclease (exosome) in mRNA degradation in yeast (34).

A mutation introduced at the 3 '-terminal or penultimate position could be mended by the polymerase machinery. RNA polymerases are known to incorporate mismatched nucleotides at high frequency. Alternatively, the machinery could synthesize oligonucleotides in a templateindependent manner and use these oligonucleotides as a primer to initiate complementary strand synthesis (35). Host enzymes might also be involved in the $3^{\prime}$-end repair. Previously, we pointed out the similarity between the $3^{\prime}$-end stem-loop structures present in the positive and negative strands of $23 \mathrm{~S}$ RNA virus and the top half-domain of tRNA (17). The acceptor stem and T stem of tRNA stack on each other coaxially and form a stem-loop structure with a single-stranded 3 '-tail referred as the top half of tRNA (Fig. 7). The structure consists of a long stem of 12-13 bp with a seven-nucleotide T $\Psi C$ loop. The top halfdomain contains the determinants necessary for specific interactions with tRNA-related enzymes, including the CCA-adding enzyme (36, 37). The positive strand of $20 \mathrm{~S}$ RNA virus also possesses a stem-loop structure with a tail of four single-stranded Cs at the 3 '-end that resembles the top half-domain of tRNA. This molecule could be a substrate of the CCA-adding enzyme (Fig. 7). A mutation introduced at the 3 '-end of the positive strand may be excised by an exonuclease. It is known that RNase T, a non-processive 3 '-exonuclease, is responsible for the end turnover of tRNA in Escherichia coli. The progression of the cleavage by this enzyme is blocked by consecutive Cs (38). Then, the shortened 3 '-end would be filled to the wild-type sequence by the CCA-adding enzyme. Consistent with this possibility is the evidence that $20-30 \%$ of 20 S RNA positive and negative strands possessed a non-templated A at their 3 '-ends when W double-stranded RNA was analyzed after $\mathrm{pCp}$ labeling (39). The negative strand of 20 S RNA has a similar secondary structure at the $3{ }^{\prime}$-end but with a much shorter stem ( $\left.8 \mathrm{bp}\right)$. This raises the possibility that the negative strand is not a good substrate for the CCA-adding enzyme. In this work, we observed that the negative strands of 20 S RNA viruses generated from a vector possessed, at a high frequency, a non-templated $\mathrm{G}$ at the $3^{\prime}$-ends (TABLE TWO). Because endogenous $20 \mathrm{~S}$ RNA virus also possesses this $\mathrm{G}$ in the negative strands at high frequency, ${ }^{6}$ it is not a phenomenon related to virus generation from a vector. In E. coli, it is known that poly(A) polymerase I and polynucleotide phosphorylase can partially compensate for the absence of the CCA-adding enzyme in the repair of the $3^{\prime}$-terminal sequence of tRNA $(40,41)$. Therefore, the extra $G$ at the $3^{\prime}$-end could be the manifestation that an enzyme other than the CCA-adding enzyme is involved in the repair of the $3^{\prime}$-end of the negative strand and that the virus somehow tolerated this $\mathrm{G}$ during its replication. Alternatively, because most of the negative strands in the lysates are present in replication complexes engaged in positive strand synthesis (11), this G may be involved in the replication process.

The positive strands of $20 \mathrm{~S}$ and $23 \mathrm{~S}$ RNA viruses form ribonucleoprotein complexes with their cognate RNA-dependent RNA poly-

${ }^{6}$ L. Vega, T. Fujimura, and R. Esteban, unpublished data. 


\section{Launching of 20 S RNA Virus from Positive/Negative Strands}

merases at a 1:1 stoichiometry and reside in the host cytoplasm. These RNAs have no poly(A) tails and perhaps no $5^{\prime}$-cap structures, thus resembling degradation intermediates of mRNAs. We expect them to be vulnerable to the exonucleases involved in mRNA turnover. This raises the possibility that the formation of ribonucleoprotein complexes is essential for virus persistence by protecting these RNA genomes in the host cytoplasm. The positive strand of $23 \mathrm{~S}$ RNA virus possesses the bipartite 3 '-cis-acting signal for replication (Fig. 7). Previously, we found that the bipartite $3^{\prime}$-signal is also important for the formation of a complex between the $23 \mathrm{~S}$ RNA genome and its RNA-dependent RNA polymerase, p104 (18). The mismatched pair of purines and the third and fourth $\mathrm{Cs}$ from the 3 '-end are essential for this activity. A mutation at the penultimate position slightly reduced the activity, whereas a modification at the $3^{\prime}$-terminal $\mathrm{C}$ did not affect the formation of the complex. These results suggest that p104 directly interacts with the third and fourth Cs from the 3 '-end and protects the viral RNA from exonucleases. The terminal and penultimate nucleotides at the $3^{\prime}$-end may be accessible to the $3^{\prime}$-repair machinery. As demonstrated in this work, the stretch of four Cs at the $3^{\prime}$-end in the 20 S RNA positive strand is also a cis-acting signal for replication. Based on analogy to 23 S RNA virus, we expect that p91 interacts with the third and fourth Cs and protects the viral 3 '-end from exonucleases. Because the negative strands are replication intermediates, they also need to be protected in the cytoplasm. The negative strands of 20 S RNA virus also form complexes with p91, as anti-p91 antiserum can immunoprecipitate the negative strands from cell lysates (42). It is likely that the stretch of four Cs at the 3 '-end in the negative strand is also involved in the formation of complexes with $\mathrm{p} 91$.

The 20 S RNA genome contains only 12 nucleotides in the 3 '-noncoding region (Fig. 3). This makes the comprehensive analysis of the 3 '-cis-acting signals (for replication or for complex formation) quite difficult without modifying the amino acid sequence of p91. As shown in this work, however, p91 can act in trans to generate 20 S RNA virus from two vectors. Therefore, it will be possible to develop an in vivo system to analyze these cis-acting signals by separately expressing the viral RNA and the polymerase p91 from two vectors. These experiments will provide information essential to understanding the molecular basis of narnavirus replication and its persistence in yeast.

\section{REFERENCES}

1. Buck, K. W. (1996) Adv. Virus Res. 47, 159-251

2. Wickner, R. B., Esteban, R., and Hillman, B. I. (2000) in Virus Taxonomy: Seventh Report of the International Committee on Taxonomy of Viruses (Van Regenmortel, M. H. V., Fauquet, C., Bishop, D. H. L., Carsten, E., Estes, M., Lemon, S. M., Maniloff, J., Mayo, M., McGeoon, D., Pringle, C., and Wickner, R. B., eds) pp. 651-656, Academic Press, Inc., New York

3. Kadowaki, K., and Halvorson, H. O. (1971) J. Bacteriol. 105, 826-830
4. Wejksnora, P. J., and Haber, J. E. (1978) J. Bacteriol. 134, 246-260

5. Rodríguez-Cousiño, N., Esteban, L. M., and Esteban, R. (1991) J. Biol. Chem. 266, $12772-12778$

6. Matsumoto, Y., and Wickner, R. B. (1991) J. Biol. Chem. 266, 12779-12783

7. Esteban, L. M., Rodríguez-Cousiño, N., and Esteban, R. (1992) J. Biol. Chem. 267, 10874-10881

8. Rodríguez-Cousiño, N., Solórzano, A., Fujimura, T., and Esteban, R. (1998) J. Biol. Chem. 273, 20363-20371

9. Esteban, R., Rodríguez-Cousiño, N., and Esteban, L. M. (1993) Prog. Nucleic Acid Res. Mol. Biol. 46, 155-182

10. Wesolowski, M., and Wickner, R. B. (1984) Mol. Cell. Biol. 4, 181-187

11. Fujimura, T., Solórzano, A., and Esteban, R. (2005) J. Biol. Chem. 280, 7398-7406

12. Widner, W. R., Matsumoto, Y., and Wickner, R. B. (1991) Mol. Cell. Biol. 11, 2905-2908

13. Esteban, L. M., Fujimura, T., García-Cuéllar, M. P., and Esteban, R. (1994) J. Biol. Chem. 269, 29771-29777

14. García-Cuéllar, M. P., Esteban, L. M., Fujimura, T., Rodríguez-Cousiño, N., and Esteban, R. (1995) J. Biol. Chem. 270, 20084-20089

15. Solórzano, A., Rodríguez-Cousiño, N., Esteban, R., and Fujimura, T. (2000) J. Biol. Chem. 275, 26428-26435

16. Esteban, R., and Fujimura, T. (2003) Proc. Natl. Acad. Sci. U. S. A. 100, 2568-2573

17. Fujimura, T., and Esteban, R. (2004) J. Biol. Chem. 279, 13215-13223

18. Fujimura, T., and Esteban, R. (2004) J. Biol. Chem. 279, 44219-44228

19. Wickner, R. B. (1980) Cell 21, 217-226

20. Fujimura, T., Esteban, R., Esteban, L. M., and Wickner, R. B. (1990) Cell 62, 819-828

21. Wickner, R. B., Icho, T., Fujimura, T., and Widner, W. R. (1991) J. Virol. 65, 155-161

22. Esteban, R., Fujimura, T., and Wickner, R. B. (1989) EMBO J. 8, 947-954

23. Maniatis, T., Fritsch, E. F., and Sambrook, J. (1982) Molecular Cloning: A Laboratory Manual, Cold Spring Harbor Laboratory, Cold Spring Harbor, NY

24. López, V., Gil, R., Carbonell, J. V., and Navarro, A. (2002) Yeast 19, 545-552

25. Perrota, A. T., and Been, M. D. (1991) Nature 350, 434-436

26. Hartley, J. L., and Donelson, J. E. (1980) Nature 286, 860-865

27. Valle, R. P., and Wickner, R. B. (1993) J. Virol. 67, 2764-2771

28. Yao, W., Muqtadir, K., and Bruenn, J. A. (1995) J. Virol. 69, 1917-1919

29. Bressanelli, S., Tomei, L., Roussel, A., Incitti, I., Vitale, R. L., Mathieu, M., De Francesco, R., and Rey, F. A. (1999) Proc. Natl. Acad. Sci. U. S. A. 96, 13034-13039

30. Butcher, S. J., Grimes, J. M., Makeyev, E. V., Bamford, D. H., and Stuart, D. I. (2001) Nature 410, 235-240

31. Ng, K. K., Cherney, M. M., Vazquez, A. L., Machin, A., Alonso, J. M., Parra, F., and James, M. N. (2002) J. Biol. Chem. 277, 1381-1387

32. Vreken, P., and Rané, H. A. (1992) Mol. Cell. Biol. 12, 2986-2996

33. Decker, C. J., and Parker, R. (1993) Genes Dev. 7, 1632-1643

34. Jacobs Anderson, J. S., and Parker, R. (1998) EMBO J. 17, 1497-1506

35. Guan, H., and Simon, A. E. (2000) Proc. Natl. Acad. Sci. U. S. A. 97, 12451-12456

36. Shi, P. Y., Maizels, N., and Weiner, A. M. (1998) EMBO J. 17, 3197-3206

37. Shi, P. Y., Weiner, A. M., and Maizels, N. (1998) RNA (N. Y.) 4, 276-284

38. Zuo, Y., and Deutscher, M. P. (2002) J. Biol. Chem. 277, 29654-29661

39. Rodríguez-Cousiño, N., and Esteban, R. (1992) Nucleic Acids Res. 20, 2761-2766

40. Reuven, N. B., Zhou, Z., and Deutscher, M. P. (1997) J. Biol. Chem. 272, 33255-33259

41. Mohanty, B. K., and Kushner, S. R. (2000) Proc. Natl. Acad. Sci. U. S. A. 97, $11966-11971$

42. García-Cuéllar, M. P. (1996) In Vitro Replication of 20 S RNA Virus from Saccharomyces cerevisiae. Doctoral dissertation, University of Salamanca, Salamanca, Spain

43. Sprinzl, M., Hartmann, T., Weber, J., Blank, J., and Zeidler, R. (1989) Nucleic Acids Res. 17, r1-r172 


\title{
20S RNA Narnavirus Defies the Antiviral Activity of SKI1/XRN1 in Saccharomyces cerevisiae ${ }^{*[5}$
}

Received for publication, June 9, 2008, and in revised form, July 18, 2008 Published, JBC Papers in Press, July 18, 2008, DOI 10.1074/jbc.M804400200

\author{
Rosa Esteban ${ }^{1}$, Lorena Vega, and Tsutomu Fujimura ${ }^{2}$ \\ From the Instituto de Microbiología Bioquímica, Departamento de Microbiología y Genética, Consejo Superior de Investigaciones \\ Científicas/Universidad de Salamanca, Salamanca 37007, Spain
}

20S RNA virus is a persistent positive strand RNA virus found in Saccharomyces cerevisiae. We previously observed that the virus generated in vivo from a launching vector possessed the correct RNA termini without extra sequences. Here we present evidence that the $S K I 1 / X R N 15^{\prime}$-exonuclease plays a major role in the elimination of the non-viral upstream sequences from the primary transcripts. The virus, once generated, however, is fairly unaffected by overexpression or deletion of SKI1/XRN1. By contrast, the copy number of the L-A double-stranded RNA virus in the same host is greatly increased by the deletion of SKI1/XRN1, and overexpression of the gene cured L-A virus from the cells at a high frequency. 20S RNA virus, unlike L-A virus, has a strong secondary structure at its $5^{\prime}$-end: the first four nucleotides are G, and they are buried at the bottom of a long stem structure, features known to inhibit the $S K I 1 / X R N 15^{\prime}$-exonuclease progression. Mutations that weakened the $5^{\prime}$-stem structure made $20 S$ RNA virus vulnerable to $S K I 1 / X R N 1$. These results, together with the data on $\mathrm{L}-\mathrm{A}$ virus, indicate a strong anti-RNA virus activity of $S K I 1 / X R N 1$. Given that 20S RNA virus resides and replicates in the cytoplasm without a protective capsid, our results suggest that the strong secondary structure at the $5^{\prime}$-end is crucial for the 20S RNA virus to evade the host SKI1/XRN1 defense.

Narnavirus 20S RNA is one of the simplest positive strand RNA viruses found in nature. The small genome (2514 nucleotides $(n t)^{3}$ ) only encodes a single 91-kDa protein (p91), the RNAdependent RNA polymerase (1-3). Despite its simplicity, the virus prospers and is widespread among laboratory strains of the yeast Saccharomyces cerevisiae as a persistent virus. All the information necessary to replicate and persist in the host is packed within its small RNA genome. The viral genome lacks a poly(A) tail at the $3^{\prime}$-end (3) and has perhaps no cap structure at the $5^{\prime}$-end, resembling an intermediate of mRNA degradation.

* This work was supported in part by Grants BFU2004-00373 and BFU200760057 from the Spanish Ministry of Education and Science. The costs of publication of this article were defrayed in part by the payment of page charges. This article must therefore be hereby marked "advertisement" in accordance with 18 U.S.C. Section 1734 solely to indicate this fact.

5 The on-line version of this article (available at http://www.jbc.org) contains supplemental Fig. S1.

${ }^{1}$ To whom correspondence should be addressed: Instituto de Microbiología Bioquímica CSIC/Universidad de Salamanca, Avda. del Campo Charro s/n Salamanca 37007, Spain. Tel.: 34-923-120673; Fax: 34-923-224876; E-mail: mrosa@usal.es.

${ }^{2}$ Recipient of a contract from the Spanish Research Program Ramón y Cajal.

${ }^{3}$ The abbreviations used are: nt, nucleotides; dsRNA, double-stranded RNA; WT, wild type; EM, electron microscopy.
The reading frame for $\mathrm{p} 91$ spans almost the entire length of the genome, and there are no genes for capsid proteins. Therefore, the RNA genome is not encapsidated into an intracellular virion structure $(4,5)$. It raises the question of how the virus avoids its RNA genome destruction by the enzymes involved in mRNA degradation pathways.

mRNA degradation in eukaryotes usually begins with the shortening of the poly (A) tail at the 3 '-end, followed by decapping at the $5^{\prime}$-end by the Dcp1p-Dcp2p-decapping enzyme (6, 7). Numerous proteins (Lsm1p-7p, Pat1p, Dhh1p, etc.) are known to assist this reaction. Then, the decapped RNA is degraded by the XRN1 5' -exonuclease. Alternatively, deadenylated RNA is digested by a multiprotein complex with $3^{\prime}$-exonuclease activity called the exosome $(8,9)$. In yeast, the XRN1 5 -exonuclease plays a major role in mRNA degradation. Although xrn1 mutants exhibit pleiotropic phenotypes, common 5'-exonuclease motifs (motifs I-III) are identified in Xrn1p, and mutations of two critical residues in motif II (D206A, D208A) abolish the 5' -exonuclease activity rather specifically without affecting functions unrelated to RNA turnover (10). The enzyme digests the RNA processively in the $5^{\prime}$ to $3^{\prime}$ direction (11), and its progression is inhibited by a $\mathrm{G}$ tract or by a strong secondary structure on the RNA $(12,13)$. A genetic approach has identified several chromosomal SKI genes affecting the double-stranded RNA (dsRNA) virus L-A and its satellite RNA M $(14,15)$. Recessive mutants of these genes exhibit a super-killer phenotype due to the derepressed production of a toxin encoded on the satellite RNA. SKI1 and XRN1 have been assigned to the same gene (16), suggesting that a higher toxin production in this mutant is due to the stability of viral RNA that has neither $5^{\prime}$ cap structure nor a $3^{\prime}$ poly(A) tail.

Although the 20S RNA virus has no capsid protein, the viral genome does not exist as naked RNA in cells. Instead, it forms a ribonucleoprotein complex with p91 in a 1:1 stoichiometry and resides in the cytoplasm $(5,17)$. This raises the possibility that formation of complexes contributes to the stability of the $20 \mathrm{~S}$ RNA genome in the cell. Recently, we have analyzed p91 in the complex and found that p91 interacts with 20S RNA at the $5^{\prime}$ and $3^{\prime}$-end regions and, to a lesser extent, at the central region as well (18). Mutations in the $5^{\prime}$ or $3^{\prime}$ cis sites reduced the formation of complexes to a basal level (10\% compared with the full activity), and a combination of them did not further reduce the activity. This suggests that the interactions of p91 at both sites are coordinated and that the central cis site is responsible for the basal level of complex formation. Further study indicated that the $3^{\prime}$ cis site is identical to or overlaps with the $3^{\prime}$ cis signal for replication (Fig. 1A). Especially, the third and fourth 


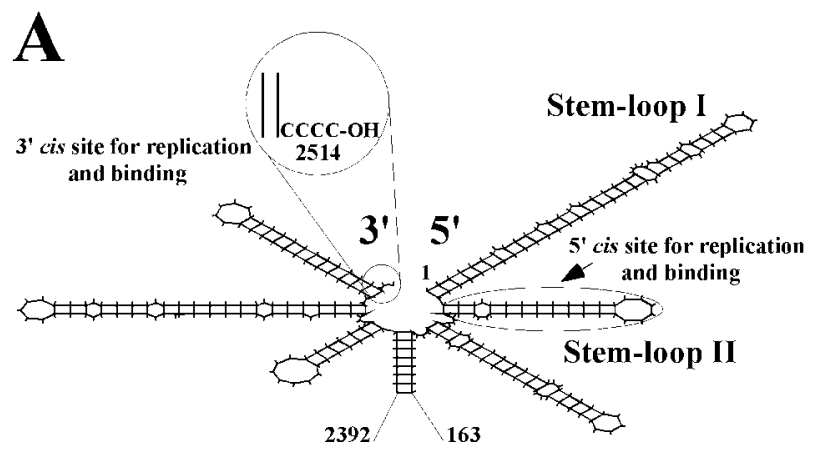

B
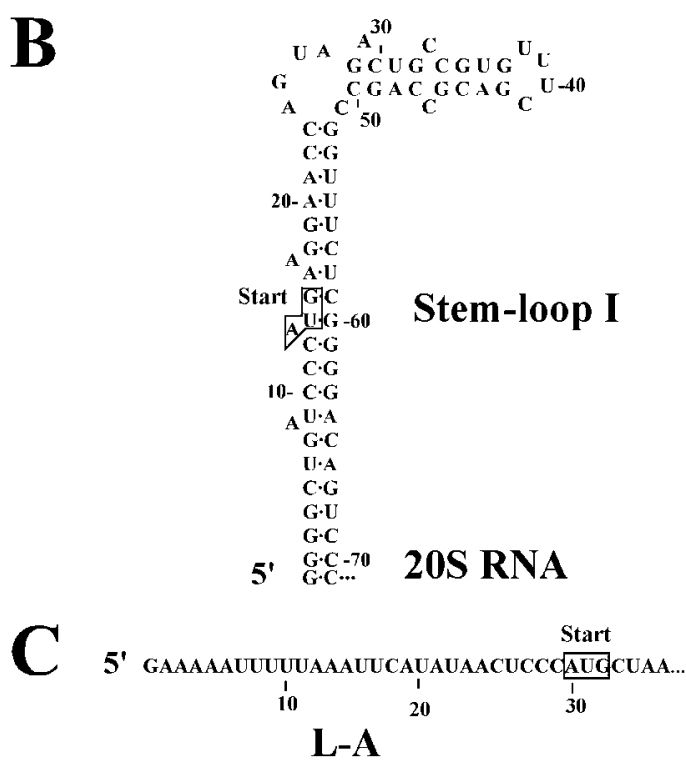

FIGURE 1. Terminal regions of the 20S RNA genome and the L-A positive strand. $A$, secondary structures in the $5^{\prime}$ - and $3^{\prime}$-terminal regions of the $20 \mathrm{~S}$ RNA genome. The $5^{\prime}$ stem-loops I and II and cis sites for replication and formation of complexes at the $5^{\prime}$ - and $3^{\prime}$-terminal regions are indicated. Nucleotides are numbered from the $5^{\prime}$-end. $B$ and $C$, nucleotide sequence of the $5^{\prime}$-terminal stem-loop I of the 20S RNA genome $(B)$ and the $5^{\prime}$-terminal sequence of the L-A positive strand $(C)$. The initiation codons (start) for p91 (B) and for the major coat protein of L-A virus $(C)$ are indicated.

nucleotides (both are C) from the 3 '-end are essential for both replication and formation of complexes. By contrast, mutations at the 3 '-terminal or penultimate position did not affect either activity. Furthermore, viruses recovered from the latter experiments had regained the wild-type nucleotide $\mathrm{C}$ by replacing the modified nucleotide at the terminal or penultimate position. This suggests that, although the 3 '-terminal and penultimate nucleotides may be removed for repair, such nibbling would not go further inside because of p91 binding. In contrast to the $3^{\prime}$ cis site, the $5^{\prime}$ cis site for complex formation is located not at the very $5^{\prime}$-terminus but at the second stem-loop structure (nt 72-104) from the $5^{\prime}$-end (Fig. 1A) (18). The terminal region (nt $1-71$ ) forms an intricate secondary structure, and the terminal nucleotide is buried at the bottom of a long stem (Fig. $1 B)$. This stem also contains the initiation codon for $\mathrm{p} 91$. If $\mathrm{p} 91$ bound to the first stem structure, it is feasible that this binding might interfere with p91 translation from the initiation codon.

In this work, we show that the 20S RNA virus is quite resistant to the SKI1 5' -exonuclease because of the secondary structure at the $5^{\prime}$-end of the genome. Weakening the $5^{\prime}$-terminal stem structure made the virus susceptible to SKI1. By contrast,
L-A virus has no strong secondary structure but an AU-rich sequence at the $5^{\prime}$-end of the positive strand (Fig. $1 C$ ) and can easily be eliminated from the cells by overexpression of SKII. These results indicate that the $S K I 15^{\prime}$-exonuclease plays a critical role in defense against RNA viruses. During the course of reverse genetics using the in vivo 20S RNA virus launching system, we observed that the $5^{\prime}$-exonuclease activity of Ski1p plays a major role in removing non-viral upstream sequences from primary transcripts containing the 20S RNA genome. DHH1 was also found to be involved in this process. Our 20S RNA virus launching system thus provides a convenient method to analyze mRNA processing in vivo.

\section{EXPERIMENTAL PROCEDURES}

Strains and Media-20S RNA-negative strain 2928-4 (a ura3 trp1 his3, 20S RNA-o, 23S RNA-o, L-A-o) has been described previously (19). Standard strain BY4741 (a ura3 $\Delta 0$, leu $2 \Delta 0$ his3 $\Delta 1$, met15 $\Delta 0$ 20S RNA-o, 23S RNA-o, L-A) and a haploid deletion series (BY4741 background) from the yeast knockout collection were a kind gift from Dr. J. L. Revuelta (Salamanca). For cytoplasmic mixing experiments (cytoduction), we used strain 1101 ( $\alpha$ kar1-1, his4, L-A, M1, 20S RNA) (20). L-A-o derivatives of the strains were constructed during this work by overexpression of the SKI1 gene. Cells were grown in rich YPAD medium ( $1 \%$ yeast extract, $2 \%$ peptone, $0.04 \%$ adenine sulfate, and $2 \%$ glucose) or synthetic medium deprived of uracil or histidine, or both (21). Induction of 20S RNA virus under nitrogen starvation was performed as described previously (22).

Genetic Methods-Standard methods for yeast genetics were used (23). Cytoduction was carried out using a strain carrying the karyogamy-deficient kar1-1 mutation (24).

Pull-down Assay-Immunoprecipitation of ribonucleoprotein complexes with anti-p91 antiserum, RNA extraction, slotblotting, and detection by Northern hybridization were described previously (18). Titration of 20S RNA transcripts in complex with p91 or in the lysates is shown in supplemental Fig. S1. Hybridization with the $\left[\gamma^{32} \mathrm{P}\right]$ ATP-labeled oligodeoxy probe RE365, that was complementary to nt 1-22 of the $20 \mathrm{~S}$ RNA genome, was done as described (25). The oligonucleotide RE368 (5' -CCTCATAAAACTGATACGAGCTTCTGCTATCC-3') was used to detect 25S rRNA.

In Vitro Mutagenesis-Site-directed in vitro mutagenesis was done as described (26). Mutations were confirmed by DNA sequencing.

Northern Hybridization-Cells were broken with glass beads as described previously (18). Phenol-extracted lysates were separated in a native agarose gel, denatured in the gel, blotted, and hybridized with ${ }^{32} \mathrm{P}$-labeled RNA probes as described (27). To analyze SKI1 transcripts, RNA samples were separated in a formaldehyde-containing denaturing gel (28) instead of using a native agarose gel. ${ }^{32} \mathrm{P}$-labeled probes to detect $20 \mathrm{~S}$ RNA and L-A positive strand genomes were made by T3 run-off transcription using SmaI-digested pALI18 (complementary to the full sequence of 20S RNA) and PvuII-digested pRE687 (complementary to nt 1323-1786 of L-A), respectively. The SKI1 specific probe was T3 run-off transcripts from SpeI-digested pRE908 that were complementary to the second half of the SKI1 
Resistance of 20S RNA Virus to SKI1 Suppression

TABLE 1

Plasmids

\begin{tabular}{lcccc}
\hline \multicolumn{5}{c}{ A. Launching plasmids (2 $\boldsymbol{\mu M}$ derivatives) } \\
\hline Name & Upstream & 20S RNA & Ribozyme & Marker \\
\hline pRE763 & $47 \mathrm{nt}$ & WT & Active & URA3 \\
pLOR38 & $19 \mathrm{nt}$ & WT & Active & URA3 \\
pLOR35 & $9 \mathrm{nt}$ & WT & Active & URA3 \\
pRE940 & $9 \mathrm{nt}$ & G69 & Active & URA3 \\
pRE941 & $9 \mathrm{nt}$ & 68 GG69 & Active & URA3 \\
pRE948 & $9 \mathrm{nt}$ & G69 & Inactive & URA3 \\
pRE949 & $9 \mathrm{nt}$ & 68GG69 & Inactive & URA3 \\
pRE950 & $9 \mathrm{nt}$ & WT & Inactive & URA3 \\
\hline \multicolumn{5}{c}{} \\
\hline Name & Bromoter & Copy number & SKI1 & Marker \\
\hline pRS313 & - & Centromeric & - & HIS3 \\
pRE908 & SKI1 & Centromeric & SKI1 & HIS3 \\
pRE921 & SKI1 & Centromeric & ski1 ${ }^{a}$ & HIS3 \\
pRE910 & - & Multicopy & - & HIS3 \\
pRE914 & PGK1 & Multicopy & SKI1 & HIS3 \\
pRE1066 & PGK1 & Multicopy & $s k i 1$ & HIS3 \\
\hline
\end{tabular}

${ }^{a}$ ski1-D206A, D208A.

gene (nt 2240-4587, numbered from the AUG initiation codon).

Launching Plasmids-pRE763 is a derivative of the 20S RNA launching vector pRE740 previously described (19). pRE763 has a 1.1-kb fragment containing the URA3 gene inserted into the unique EcoRV site in the TRP1 marker of pRE740. The rest of the launching plasmids were made from pRE763 by site-directed in vitro mutagenesis. The changes introduced into the vector or 20S RNA sequence are indicated in Table 1.

Cloning of SKI1 - The SKI1 gene was amplified by PCR from strain 2928-4 with oligos RE298 (5' -AATTAGGATCCAATCCAAACATTGTGCCCAC-3') and RE299 (5' -AATTAGGATCCGGTTTGCTAAGCAAAATGAG-3'). The DNA fragment $(5.5 \mathrm{~kb})$ contains the $S K I 1$ open reading frame flanked by a 0.5 -kb upstream sequence with the SKII promoter and a 0.25 -kb downstream sequence with polyadenylation and transcription termination signals. The PCR fragment was cloned into the unique BamH1 site of the pRS313 centromeric vector (29), resulting in plasmid pRE908. The cloned sequence of the SKI1 gene was confirmed by DNA sequencing. The SKI1 overexpression vector pRE914 was constructed as follows: A 4.7-kb DNA fragment containing the SKI1 coding sequence was amplified by PCR from strain 2928-4 with oligos RE296 (5' AATTAGGATCCCAGTACGGTATGGGTATTC-3') and RE297 (5'-AATTAGGATCCGTCGTATGTTCTAAGTAGA$\left.3^{\prime}\right)$. Nucleotides corresponding to the initiation and termination codons are underlined. The amplified fragment was cloned downstream of the PGK1 promoter of vector pRE910, giving plasmid pRE914. Vector pRE910 is a derivative of pI2 (30) and has a 1.1-kb fragment containing the HIS3 marker inserted into the unique EcoRV site, interrupting the TRP1 gene of pI2.

\section{RESULTS}

SKI1 Contributes to the Efficient Generation of 20S RNA Virus in Vivo-We have recently established an in vivo launching system for 20S RNA virus from a yeast expression vector (19). The vector contains the entire 20S RNA cDNA sequence downstream of the PGK1 promoter. The hepatitis delta virus antigenomic ribozyme sequence is directly attached to the $3{ }^{\prime}$-end of the viral genome in the vector to facilitate the creation of the
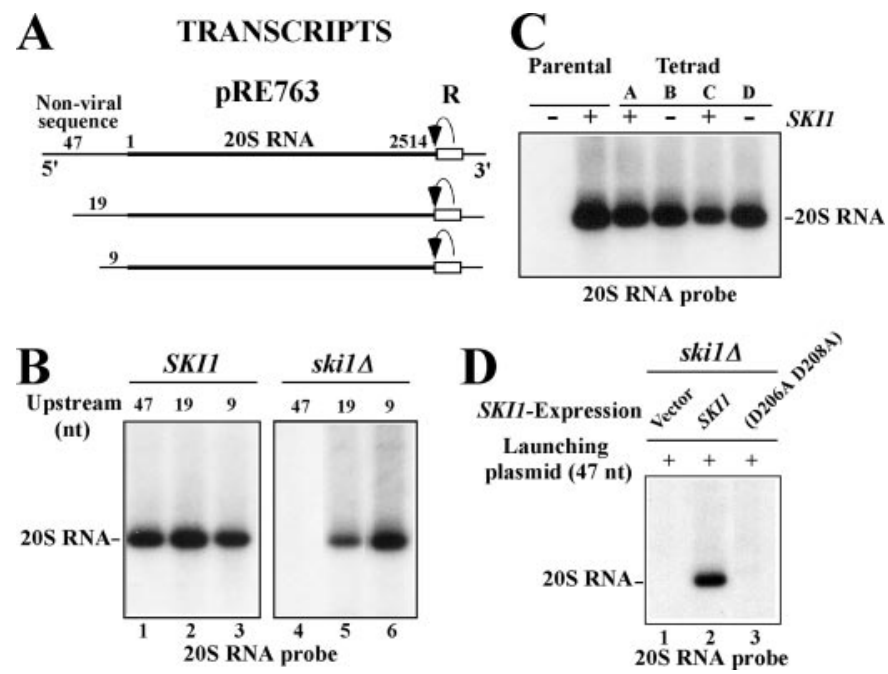

FIGURE 2. The SKI1 5' -exonuclease has a major role in the $5^{\prime}$ processing of the primary transcripts to generate 20S RNA virus in vivo. $A$, diagrams of 20S RNA transcripts produced in vivo from the standard launching plasmid pRE763 or derivatives thereof. The 20S RNA genome sequence is depicted with the bold line and numbered 1-2514. Thin lines indicate the non-viral sequences flanking the viral genome. The hepatitis delta virus antigenomic ribozyme sequences $(R)$ attached to the $3^{\prime}$-end of the viral genome are boxed, and the curved arrow indicates the cleavage site. The standard launching plasmid has $47 \mathrm{nt}$ as the non-viral upstream sequence in the transcripts, while the derivatives have shorter (19 and $9 \mathrm{nt}$ ) upstream sequences. $B$, ski1 $\Delta$ strain failed to generate 20S RNA virus from the standard launching plasmid. A SKI1 (lanes 1-3) or ski1s (lanes 4-6) strain was transformed with the standard launching plasmid (lanes 1 and 4) or with a plasmid having a shorter upstream sequence (19 or $9 \mathrm{nt}$ ) (lanes 2, 3, 5, and 6). Phenol-extracted lysates were separated on $1.3 \%$ agarose gels and blotted onto nylon membranes. RNA on the membranes was detected by Northern hybridization with a 20S RNA specific probe. The position of 20S RNA is indicated. C, 20S RNA virus does not require $S K I 1$ for its replication. RNA from one tetrad $(A-D)$ and the parental strains was extracted, and the viral RNA in the extracts was analyzed as described in B.D, SKI1 on a centromeric vector complements the ski1 $\Delta$ strain to generate 20S RNA virus from the standard launching plasmid. The ski1 $\Delta$ strain was first transformed with a centromeric vector alone (lane 1), or the vector with SKI1 (lane 2), or ski1-D206A, D208A (lane 3). Then the transformants were again transformed with the standard launching plasmid. 20S RNA virus generated was detected as described in $B$.

precise viral $33^{\prime}$-end termini in the transcripts (Fig. 2A). Although the vector contained a non-viral sequence between the major transcription start site for the PGK1 promoter and the $5^{\prime}$-end of the viral genome, the virus generated had the authentic $5^{\prime}$-terminus without this non-viral vector sequence. Using this launching system, we examined the effects of host genes on virus generation. When a ski1s mutant strain was used as a host, we found that the standard launching plasmid failed to generate the virus (Fig. 2B, lane 4). Although this mutant strain showed severe defects in mating and meiosis, we found that the cells could support replication of 20S RNA when the virus was introduced by a cytoplasmic mixing (cytoduction) (not shown). Furthermore, two tetrads obtained from a cross with a 20S RNA-carrying strain produced a 4+:0 segregation of 20S RNA virus (Fig. 2C), indicating that the virus does not require $S K I 1$ for its replication. Because the primary transcripts from the vector contain the $5^{\prime}$ cap structures as well as $47 \mathrm{nt}$ of non-viral upstream sequences, we suspected that the failure in generating virus from the standard launching plasmid was caused by the inefficient removal of the non-viral $5^{\prime}$ sequence from the transcripts. When this upstream sequence was reduced from 47 to $19 \mathrm{nt}$ or to $9 \mathrm{nt}$, the vectors successfully 


\section{Resistance of 20S RNA Virus to SKI1 Suppression}
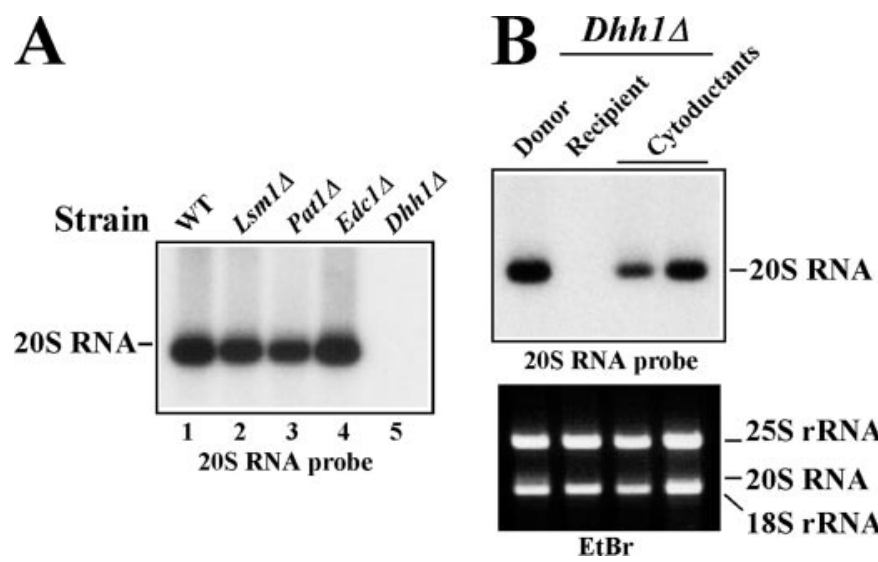

FIGURE 3. Effects of genes involved in mRNA decapping on 20S RNA launching. $A$, control strain BY4741 (lane 1) or a strain deleted in LSM1 (lane 2), PAT1 (lane 3), EDC1 (lane 4), or DHH1 (lane 5) was transformed with the standard launching plasmid. 20S RNA virus generated was detected as described in the legend to Fig. 2B. B, 20S RNA virus was introduced from strain 1101 (Donor) into a dhh1 $1 \Delta$ strain (Recipient) by cytoduction. 20S RNA in two cytoductants and in the donor and recipient strains was analyzed as described in Fig. $2 B$. Ethidium bromide staining of the gel is also shown (EtBr). The positions of $20 \mathrm{~S}$ RNA and $25 \mathrm{~S}$ and $18 \mathrm{~S}$ rRNAs are indicated.

generated the virus in the ski1 $\Delta$ strain (Fig. $2 B$, lanes 5 and 6). In particular, the shortest one generated the virus almost as efficiently as in the isogenic wild-type strain (Fig. 2B, lanes 3 and 6). Translation of p91 was not affected by these modifications in the upstream sequence (not shown). Once the virus was generated, ski1 $\Delta$ cells could maintain it stably even after curing the launching plasmid. Next, we amplified a 5.5-kb DNA fragment encompassing the SKI1 gene from the wild-type strain 2928-4 and cloned it into a single copy centromeric vector. The authenticity of the gene was confirmed by DNA sequencing. When the ski1s strain was transformed with the vector expressing Ski1p, now the cells could generate 20S RNA virus from the standard launching plasmid (Fig. 2D, lane 2). Furthermore, cells transformed with the vector containing ski1D206A,D208A failed to generate the virus under the same conditions (Fig. 2D, lane 3). These mutations are known to abolish the $5^{\prime}$-exonuclease activity of the gene product (10). These results indicate that the inability of the ski1 $\Delta$ strain to generate the virus is indeed caused by the deletion of SKI1 and point out the importance of eliminating the non-viral $5^{\prime}$-upstream sequence for virus generation. Because decapping precedes 5 '-exonuclease cleavage in mRNA turnover, we examined the effects on 20S RNA virus generation of the genes involved in mRNA decapping. Among them, we chose some components of the Lsm1p-7p/Pat1p complex (Lsm1p, Lsm6p, Lsm7p, and Pat1p), Dhh1p, an RNA helicase that is necessary for the decapping activity of Dcp1p-Dcp2p, and Edc1p, an enhancer of the decapping activity (31-33). We did not test deletions of DCP1 and $D C P 2$ because these are essential genes. Strains deleted in LSM1, LSM6 (not shown), LSM7 (not shown), PAT1, or EDC1 could generate 20S RNA virus from the standard launching plasmid (Fig. 3A) or from a launching plasmid with a 9-nt upstream sequence (not shown). However, we were unable to launch 20S RNA in the dhh1 $1 \Delta$ mutant from either plasmid (Fig. $3 A$, lane 5; and not shown). To examine whether the failure of the $d h h 1 \Delta$ strain to generate virus is caused by the inability to

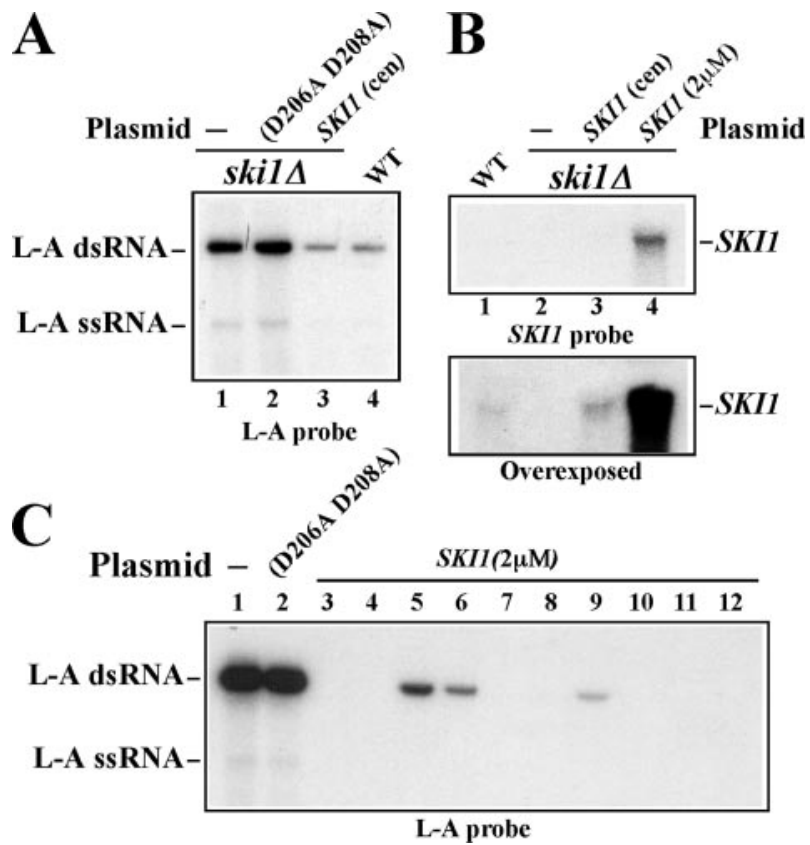

FIGURE 4. The SKI1 5'-exonuclease has a strong anti-L-A virus activity. $A$, suppression of L-A virus by a single-copy of the SKI1 gene. L-A viral RNA was extracted and analyzed as described in the legend to Fig. $2 B$ except that an L-A positive strand specific probe was used. Lane 1, ski1 $\Delta$ strain; lane 2, ski1 $\Delta$ strain with ski1-D206A, D208A in a centromeric vector; lane 3, ski1 $\Delta$ strain with SKI1 in a centromeric vector; lane 4, SKI1 strain BY4741. B, expression of SKI1 transcripts from a centromeric or a multicopy vector. RNA was extracted from late logarithmic phase cells and separated in a denaturing agarose gel. After blotting, SKI1 transcripts were detected with a SKI1 specific probe. The lower panel is overexposed to reveal $S K I 1$ transcripts from a single copy gene. Lane 1, SKI1 strain BY4741; lane 2, ski1 $\Delta$ strain; lane 3, ski1 $\Delta$ strain transformed with a SKI1 centromeric vector; lane 4, ski1 $\Delta$ strain transformed with a SKI1 multicopy vector. C, curing of L-A virus by SKI1 overexpression. A ski1 $\Delta$ strain was transformed with a SKI1-overexpressing multicopy vector (lanes 3-12) or the vector with ski1-D206A, D208D (lane 2). L-A virus was analyzed as described in A. Lane 1, the non-transformed ski1 $\Delta$ strain.

support 20S RNA replication or by its defect in RNA processing, we introduced 20S RNA virus into $d h h 1 \Delta$ cells by cytoduction. As shown in Fig. 3B, cytoductants received the virus from the donor strain and maintained it during the subsequent colony isolation procedure. We observed no effects of $d h h 1 \Delta$ on the level of 20S RNA introduced. This indicates that the $d h h 1 \Delta$ strain has no defects in supporting 20S RNA virus replication. These results demonstrate that host genes involved in RNA processing could affect 20S RNA virus generation in this launching system. Therefore, it is necessary to distinguish them from those genuinely involved in virus replication by genetic or other means.

Differential Effects of the SKI1 Gene on Yeast RNA VirusesThe SKI1 gene product suppresses the copy number of L-A dsRNA virus. We observed that the amount of $\mathrm{L}-\mathrm{A}$ virus is 5-10 times higher in the ski1 $\Delta$ strain than in the isogenic SKI1 wildtype strain (Fig. 4A, lanes 1 and 4). SKI1 on a centromeric vector reduced the amount of L-A to the wild-type level, while ski1D206A, D208A showed no such suppressive activity (Fig. 4A, lanes 2 and 3). We subcloned the $S K I 1$ open reading frame into a $2 \mu \mathrm{M}$ based multicopy vector, downstream of the constitutive PGK1 promoter. The expression of the SKI1 transcripts is at least 50 times higher than that from the centromeric vector or from the single gene in the yeast chromosome (Fig. $4 B$ ). When 
A

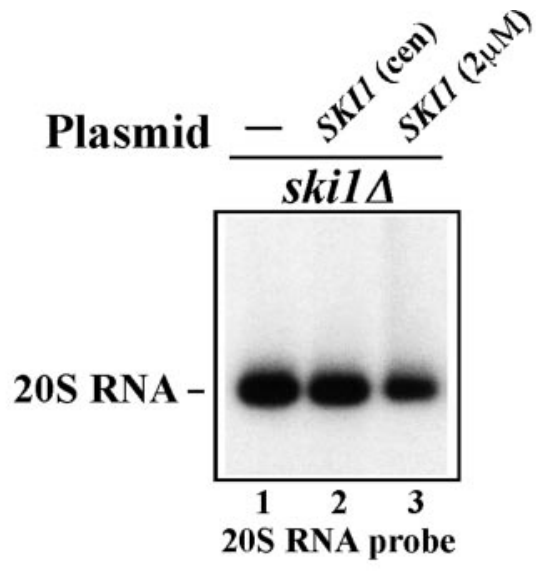

B ski1 $\Delta$

\begin{tabular}{|c|c|c|c|c|}
\hline \multirow{3}{*}{$\begin{array}{l}\text { 20S RNA } \\
\text { Plasmid }\end{array}$} & \multicolumn{2}{|c|}{ WT } & \multicolumn{2}{|c|}{ 68GG69 } \\
\hline & Vector & SKII & Vector & SKI1 \\
\hline & 1 & 4 & 6 & 7 \\
\hline
\end{tabular}

20S RNA -

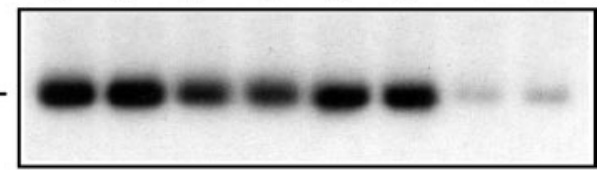

20S RNA probe

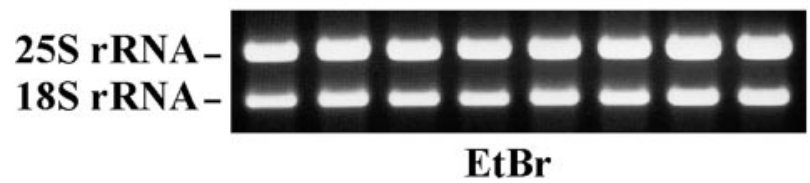

FIGURE 5. Effects of SKI1 on 20S RNA virus. A, wild-type 20S RNA virus is quite insensitive to $S K I 1$ overexpression. ski1 $\Delta$ strain carrying wild-type $20 S$ RNA virus was transformed with a SKI1 centromeric vector (lane 2) or with a SKI1 multicopy vector (lane 3). Lane 1, 20S RNA virus-carrying ski1 $\Delta$ strain without plasmid as control. B, 20S RNA with the 69GG69 mutation becomes sensitive to SKI1 suppression. ski1 $\Delta$ strain carrying wild-type 20S RNA virus (lanes 1-4) or virus with the 68GG69 mutation (lanes 5-8) was transformed with a SKI1-overexpressing multicopy vector (lanes 3, 4, 7, and 8 ) or the vector alone (lanes 1, 2, 5, and 6). Two transformants from each experiment were analyzed. 20S RNA was detected as described in the legend to Fig. 2B. The lower panel shows $25 \mathrm{~S}$ and $18 \mathrm{~S}$ rRNAs stained with ethidium bromide as loading control. The photograph was taken before blotting. The strains used in $A$ and $B$ have no $L-A$ virus.

the ski1 $\Delta$ strain was transformed with the SKI1 multicopy vector, the transformants lost the L-A virus at a high frequency (7 of 10) (Fig. 4C, lanes 3-12). We confirmed the loss of L-A virus by curing the plasmid. By contrast, transformants with the vector alone (not shown) or with ski1-D206, D208A retained a high amount of L-A virus as the original non-transformed cells (Fig. $4 C$, lanes 1 and 2). These results demonstrate a strong anti- $\mathrm{L}-\mathrm{A}$ virus activity of the SKI1 5' -exonuclease. We also analyzed the effects of SKI1 on 20S RNA virus. Because the copy number of $\mathrm{L}$-A virus is very high in the ski1 $\Delta$ strain, its presence affects the copy number of 20S RNA in the same cell, perhaps by competing for resources such as nucleotide precursors, energy, etc. In the following experiments, therefore, we used an L-A-o strain. SKI1 on the centromeric vector had almost no effect on $20 \mathrm{~S}$ RNA virus, and SKI1 even on the multicopy vector only slightly reduced the amount of $20 \mathrm{~S}$ RNA virus (Fig. $5 A$ ). In the latter case, we did not observe any segregation of 20S RNA-free colonies. In contrast to L-A virus, therefore, 20S RNA virus is quite resistant to SKI1.

The 5'-Terminal Structure Contributes to Resistance of $20 \mathrm{~S}$ RNA Virus to SKI1-We wondered why 20S RNA and L-A viruses differentially respond to the SKI1 5'-exonuclease. The dsRNA genome of L-A virus is encapsidated into intracellular viral particles. Isolated particles protect the RNA genome from RNase A treatment (27). EM studies indicated that the capsid has holes with a size large enough for newly synthesized transcripts to pass through into the cytoplasm, but too small for the entry of globular proteins $(34,35)$. Thus, it is the non-encapsidated cytoplasmic stage of L-A positive strand transcripts that appears to be vulnerable to the $5^{\prime}$-exonuclease.

The $5^{\prime}$-terminal region of the $\mathrm{L}$-A positive strand contains an AU-rich sequence and does not show strong secondary structures (Fig. 1C). By contrast, 20S RNA has a strong secondary structure at the $5^{\prime}$-end, and the $5^{\prime}$-terminal nucleotide is buried at the bottom of the stem (Fig. $1 B$ ). Furthermore, the first four nucleotides at the $5^{\prime}$-terminus are G. It is known that oligo G tracts and strong secondary structures inhibit the progression of the 5' SKI1 exonuclease $(13,36)$. We therefore, hypothesized that this strong secondary structure contributes to the insensitivity of 20S RNA virus to SKI1 suppression. To examine this hypothesis, we introduced mutations in the launching plasmid to destabilize the $5^{\prime}$-end structure of the 20S RNA genome. Because the ski1 $\Delta$ strain failed to generate 20S RNA virus from the standard launching plasmid (Fig. 2B), we used the plasmid having a shorter $(9 \mathrm{nt})$ non-viral upstream sequence. The first mutant plasmid (G69) contains a single substitution at the position 69 (C to $\mathrm{G}$ ) and creates a single mismatch at the lower part of the stem (Fig. 6A). This mutation does not alter the amino acid sequence of p91. The second plasmid (68GG69) harbors two substitutions (68UC69 to GG), destabilizing the stem more profoundly and encodes p91 modified at codon 19, from wildtype Val to Gly (Fig. 6A). We transformed the SKI1 strain with these plasmids as well as with the control plasmid having the wild-type 20S RNA sequence. Transformants with the first plasmid (G69) generated 20S RNA virus, but its amount was less compared with the control (Fig. 6B, lanes 1 and 2). Their ratio remains similar after curing the plasmid (not shown), indicating that the virus with this mutation is less stable. More significantly, the second plasmid (68GG69) failed to generate virus (Fig. 6B, lane 3). Because this second plasmid encodes a modified p91, its failure to generate virus could be attributed to the amino acid change (V19G) in the protein. To eliminate this possibility, the following two experiments were carried out. We previously showed that transcripts containing the 20S RNA negative strand genome did not generate virus because p91, essential for replication, could not be decoded from them. When an active $\mathrm{p} 91$ was provided from a second vector, the negative strand transcripts generated 20S RNA virus (19). We introduced the V19G mutation into the p91 coding sequence on the second vector and found that the modified p91 could generate virus from the negative strand transcripts (not shown), indicating that the protein is capable of, at least, a first round of positive strand synthesis. More direct evidence comes from the experiments shown in Fig. 6B, lanes 4-6. Here, a 
A

$$
\begin{aligned}
& 1 \mid \\
& \begin{array}{c}
\mathrm{A} \cdot \mathrm{U} \\
\mathrm{G} \cdot \mathrm{C}
\end{array} \\
& \text { Start } \frac{\mathrm{U}}{\mathrm{C} \cdot \mathrm{G}}-\mathbf{G} \\
& \text { C.G Gly } \\
& \text { 10- } \mathrm{C} \cdot \mathrm{G} \\
& \text { A } \begin{array}{l}
\mathbf{U} \cdot \overline{\mathbf{A}} \\
\mathbf{C}
\end{array} T h \\
& \text { U. } \underline{\mathbf{A}} \\
& \text { C. G } \\
& \text { G.U (IaI) } \\
& \text { G.C }-69 \\
& \mathrm{G} \cdot \overline{\mathrm{C}}_{\text {Pro }} \\
& \text { 5' G.C }
\end{aligned}
$$

WT
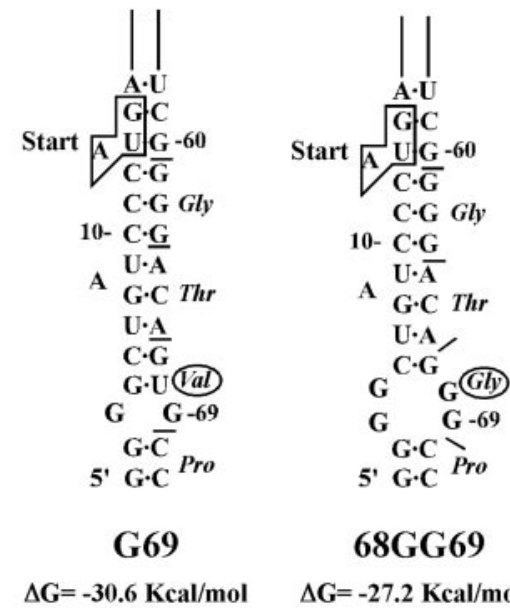

$\Delta \mathbf{G}=-\mathbf{3 4 . 4} \mathrm{Kcal} / \mathrm{mol}$
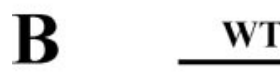

\section{T} ski14

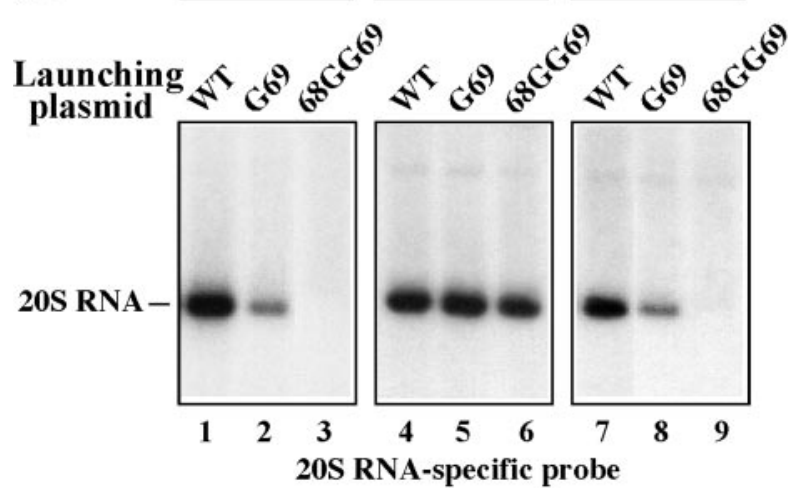

FIGURE 6. Mutant viruses with destabilized $5^{\prime}$-terminal stem structures become susceptible to SKI1 suppression. $A, 5^{\prime}$-terminal stem structures of WT and G69 and 68GG69 mutant 20S RNA viruses. Only the lower half of the 5 '-terminal stem-loop structure is shown. Nucleotides are numbered from the $5^{\prime}$-end. Small bars indicate the coding frame of p91 and the initiation codon (start) is boxed. Note that the 68GG69 mutation causes an amino acid change at codon 19 from Val to Gly (indicated with circles). The free energy of each structure (nt 1-71) is shown. B, wild type SKI1 (lanes 1-3) or ski1 $\Delta$ strain (lanes 4-6), or the ski1 $\Delta$ strain complemented with a SKI1 centromeric vector (lanes 7-9) was transformed with 20S RNA launching plasmids containing the wild-type sequence (lanes 1, 4, and 7) or with the G69 (lanes 2, 5, and 8) or 68GG69 (lanes 3, 6, and 9) mutation. 20S RNA virus generated was analyzed as described in the legend to Fig. $2 B$.

$s k i 1 \Delta$ strain was transformed with the same three plasmids. Not only G69 but also 68GG69 mutant plasmids generated virus, and the amounts of 20S RNA in these transformants are indistinguishable from the one having the wild-type viral sequence. We confirmed that viruses generated from G69 and 68GG69 mutant plasmids in the ski1 $\Delta$ strain were not revertants. Viral RNA was isolated from plasmid-cured cells, and the $5^{\prime}$-end region was amplified by reverse transcription-PCR. Sequencing five independent cDNA clones indicated that the viruses retained the respective mutations originally introduced in the launching plasmids. Thus p91 with the V19G mutation is active and has no defects in replication. Furthermore, the ski1 $\Delta$ strain harboring a SKI1-expressing centromeric plasmid failed to generate virus from the 68GG69 mutant plasmid and generated virus from the G69 mutant plasmid but in a lesser amount, as the wild-type SKI1 strain did (compare lanes 1-3 to lanes 7-9 in Fig. $6 B$ ). Therefore, $S K I 1$ is responsible for the instability of the mutant viruses and in the absence of the gene product, even $20 \mathrm{~S}$ RNA virus with the 68 GG69 mutation can propagate normally as the wild-type virus does.

20S RNA Virus with the 68GG69 Mutation Becomes Vulnerable to SKI1 Suppression-20S RNA virus with the 68GG69 mutation was generated from a launching plasmid in the ski1 $\Delta$ strain but not in the SKI1 strain. Here we asked whether this mutant virus after its generation in the ski1 $\Delta$ strain is still susceptible to SKI1. We cured the launching plasmid from the ski1 $\Delta$ strain that had generated the mutant virus. Then the cells were transformed with a SKI1-expressing multicopy vector or with the vector alone (Fig. 5B, lanes 5-8). As control, the ski1 $\Delta$ strain with wild-type $20 \mathrm{~S}$ RNA virus was processed similarly (Fig. 5B, lanes 1-4). As observed earlier (Fig. 5A), wild-type virus was only slightly affected by the overexpression of SKI1 (Fig. 5B, compare lanes 3 and 4 with lanes 1 and 2). By contrast, the mutant virus was reduced by more than $90 \%$ by SKI1 (Fig. $5 B$, compare lanes 5 and 6 with lanes 7 and 8 ). Thus the mutant virus becomes more susceptible to SKI1 compared with the wildtype virus, and this vulnerability is not related with the launching process from a vector. These results confirm that the integrity of the $5^{\prime}$-end structure is critical for the virus to resist SKI1 suppression. Unlike in the case of L-A virus, however, the cells harboring the mutant 20S RNA viruses did not produce virus-free colonies by the overexpression of SKII.

The G69 and 68GG69 Mutations Do Not Directly Affect the Formation of Ribonucleoprotein Complexes between $20 S$ RNA and the RNA Polymerase p91-The genomic RNA of 20S RNA virus forms a ribonucleoprotein complex in vivo with its RNA polymerase $\mathrm{p} 91$. We have recently shown that p91 interacts with the RNA at the $5^{\prime}$ - and $3^{\prime}$-end regions, and to a lesser extent, at the central region. The $5^{\prime}$ cis site is present at the second stem-loop structure (nt 72-104) from the $5^{\prime}$-end (Fig. 1A). Because the two mutations G69 and 68GG69 destabilize the $5^{\prime}$-terminal stem-loop structure, and because they are located close to the $5^{\prime}$ cis site for formation of complexes, we examined whether these mutations affect the formation of ribonucleoprotein complexes. Transcripts containing the $20 \mathrm{~S}$ RNA genome with the wild-type sequence or with mutations were expressed in vivo from a vector. The HDV ribozyme in the vector had been inactivated by replacing GGG 3 ' to the cleavage site with AAA; thus the vector could not generate the virus (19, 37). The transcripts, however, served as mRNAs to translate p91 as well as substrates to form complexes with the decoded p91. We analyzed 20S RNA transcripts in these complexes by a pull-down assay using anti-p91 antiserum followed by Northern blot. In the ski1 $\Delta$ strain, the antiserum immunoprecipitated transcripts with the wild-type sequence and also with the G69 or 68GG69 mutation, and their amounts were almost indistinguishable (Fig. $7 A$, right panel). This indicates that neither mutation affects the formation of complexes with p91. These results are consistent with previous data (Fig. $6 B$ ) showing that both mutations did not affect virus generation from a launching vector in a ski1D strain. In a SKI1 strain, however, the G69 mutation reduced the formation of complexes by $70 \%$ and the 68 GG69 mutation by $90 \%$. This may suggest that the SKI1 product directly impedes $\mathrm{p} 91$ to form complexes with the mutant RNAs. However, considering that the gene product has 


\section{Resistance of 20S RNA Virus to SKI1 Suppression}
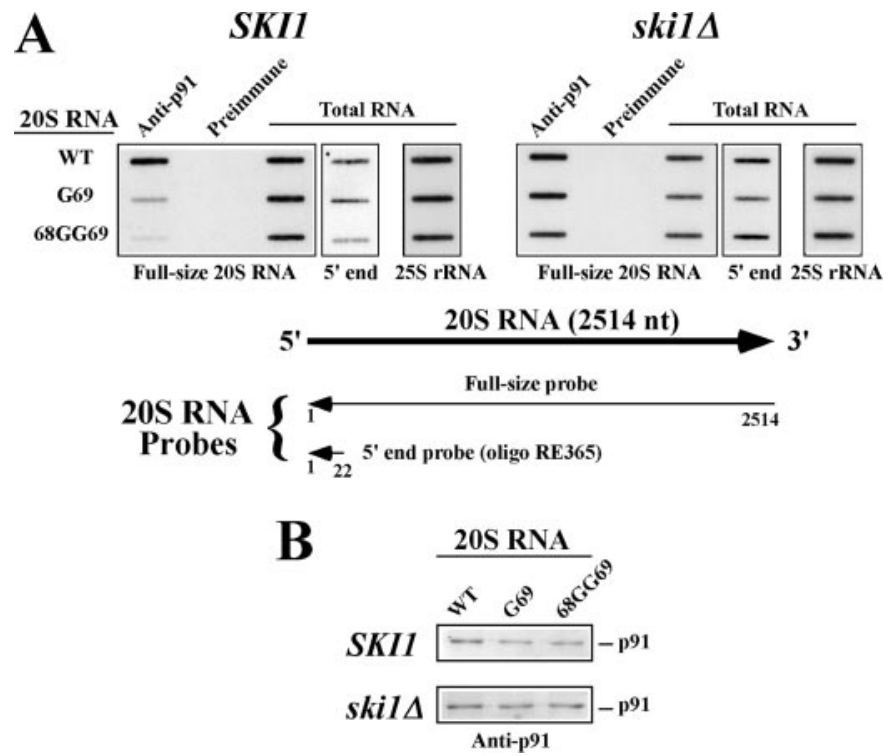

FIGURE 7. 5'-terminal mutations G69 and 68GG69 do not directly affect the formation of ribonucleoprotein complexes and p91 translation. $A$, effects of the G69 and 68GG69 mutation on the formation of ribonucleoprotein complexes. The SKI1 (left panels) or ski1s (right panels) strain was transformed with a ribozyme-inactivated plasmid expressing the wild-type 20S RNA sequence (WT) or 20S RNA with the G69 (G69) or 68GG69 (68GG69) mutation. Because these plasmids have an inactive ribozyme, they do not generate 20S RNA virus. Lysates prepared from logarithmically growing cells were incubated with anti-p91 antiserum (Anti-p91) or preimmune serum (Preimmune). RNA was extracted from the immunoprecipitates, blotted, and hybridized with a full-size 20S RNA probe. RNA directly extracted from the lysates (Total RNA) was processed similarly and detected with three different probes: a full-size 20S RNA probe (Full-size 20S RNA), a 22-nt 20S RNA $5^{\prime}$-end oligo probe $\left(5^{\prime}\right.$-end), and a $25 \mathrm{~S}$ rRNA-specific oligo probe (25S $r R N A)$. 25S rRNA serves as loading control. The diagrams below illustrate the two 20S RNA specific probes that were used. $B$, Western blot of p91 present in the cell lysates used in $A$.

$5^{\prime}$-exonuclease activity and that these mutant RNAs have no defects in forming complexes with p91 in the ski1 $\Delta$ strain, however, a more feasible explanation is that the effects of SKI1 on complexes are secondary. It is likely that the amount of mutant transcripts available for formation of complexes is lower compared with that of the wild-type sequence because of a greater susceptibility of the mutant RNAs to the Ski1p digestion. Alternatively, transcripts with the wild-type 20S RNA sequence in the complexes are more resistant to the Skilp digestion by stopping the enzyme at the viral $5^{\prime}$-end, by virtue of the intact 5 '-terminal secondary structure, whereas the destabilized 5 '-terminal structures in the mutant RNAs fail to stop Ski1p and allow the enzyme to further digest the RNA, eventually releasing $\mathrm{p} 91$ from the $5^{\prime}$ cis site. At any rate, the results suggest that the interaction of p91 with the $5^{\prime}$ cis site for complex formation does not protect the viral $5^{\prime}$-end from the SKII 5' -exonuclease. These explanations are consistent with the following observations. When the transcripts in the lysates (total RNA) from the SKI1 strain were detected with a full-size probe for $20 \mathrm{~S}$ RNA, we found no significant difference in the amounts of mutant and wild-type RNAs (Fig. 7A, left panel). However, a 5' oligo probe complementary to the first $22 \mathrm{nt}$ of the viral genome detected 68GG69 mutant transcripts 30\% less compared with the wild-type transcripts (Fig. 7A, left panel). As expected, the same oligo probe showed no noticeable differences between the wild type and 68GG69 mutant transcripts in the ski1s lysates
(Fig. 7A, right panel). These results indicate that a small fraction of 68GG69 mutant transcripts lack the 5 '-terminal region of the viral sequence in the SKI1 background. Finally, we confirmed that the G69 and 68GG69 mutations did not significantly affect the expression of p91 from vectors in the SKI1 or ski1 $\Delta$ strain (Fig. $7 B$ ). Therefore, the decrease in the formation of complexes with these mutant transcripts in the SKI1 strain should be attributed to the vulnerability of the mutant RNA transcripts to the SKI1 product.

\section{DISCUSSION}

In this work we have studied the effects of SKI1 on 20S RNA virus on two different aspects. One is on the launching process of 20S RNA virus from a vector and the other on the virus per se. These effects should be clearly distinguished.

The primary transcripts from the launching vector contain the 20S RNA viral genome flanked by non-viral sequences at both the $5^{\prime}$ - and $3^{\prime}$-ends. The transcripts have $5^{\prime}$ cap structures and poly(A) tails at their $3^{\prime}$-ends as well. Virus generated from the vector has no such extra sequences. Thus these sequences must be eliminated during the launching process.

The importance of the 5 '-end processing for in vivo launching was demonstrated by the failure of a ski1 $\Delta$ strain to generate 20S RNA virus from our standard launching plasmid. 20S RNA virus, however, does not require the SKI1 gene product for its replication because the ski1 $\Delta$ strain can support virus replication when 20S RNA is introduced by the cytoplasmic mixing that occurs during mating. Furthermore, the ski1 $\Delta$ strain successfully generated the virus when the 5 '-upstream sequence in the primary transcripts was reduced from $47 \mathrm{nt}$ in the standard launching plasmid, to $19 \mathrm{nt}$ or to $9 \mathrm{nt}$. Thus, a shorter $5^{\prime}$-upstream sequence is critical to generate the virus in a ski1 $\Delta$ genetic background. Finally, a centromeric vector containing SKI1 but not ski1-D206A, D208A complemented the defect of the ski1 $\Delta$ strain to generate virus from the standard launching plasmid. These results indicate that the SKI1 5'-exonuclease plays a major role in the $5^{\prime}$-processing of the primary transcripts. In the absence of SKI1 there is still a minor activity that is capable of eliminating a shorter $5^{\prime}$-upstream sequence. This suggests the involvement of a $5^{\prime}$-exonuclease rather than an endonuclease in the latter activity. S. cerevisiae has the essential RAT1 gene that encodes a nuclear 5 '-exonuclease with a high degree of similarity to the SKII enzyme (38). Recently it has been suggested that yeast mitochondria have a 5 '-exonuclease involved in apocytochrome $b$ mRNA processing whose activity is governed by PET127 (39). These exonucleases could be candidates for the minor $5^{\prime}$-upstream processing activity found in our launching system. The SKI1 5' -exonuclease utilizes RNA with a $5^{\prime}$-monophosphate as substrate but cannot act on $5^{\prime}$-capped RNA (13). Thus the cap structure must be eliminated from the primary transcripts prior to the SKII action. Numerous genes are known to promote decapping. We chose strains deleted in genes belonging to the Lsm1p-7p/Pat1p complex, $E D C 1$, or $D H H 1$. None of them except for the $d h h 1 \Delta$ strain significantly affected virus generation from the standard launching plasmid and also from a plasmid with a shorter upstream sequence ( $9 \mathrm{nt}$ ). Although the $d h h 1 \Delta$ strain failed to generate virus from either plasmid, this strain could propagate 
and maintain the virus when it was introduced by cytoduction. Thus, the 20S RNA virus does not require $D H H 1$ for replication. Similar to the case of $S K I 1$, the $D H H 1$ product appears to affect the processing of primary transcripts from the plasmid. Because Dhh1p is known to stimulate the decapping activity of a Flag-purified Dcp1p preparation in vitro (33), our results suggest that $d h h 1 \Delta$ affects the decapping activity of the Dcp1pDcp2p complex more severely than do the other mutations examined. Because the launching plasmid with the shorter upstream sequence failed to generate the virus in a $d h h 1 \Delta$ strain, the minor $5^{\prime}$-exonuclease activity observed in the ski1s strain appears to require decapping of the primary transcripts prior to its action.

Concerning the 3 '-end, we previously observed that the HDV ribozyme directly attached to the 3 '-end of the viral genome in the vector was critical for virus generation (19). The inactivation of the ribozyme or elimination of the ribozyme sequence from the vector resulted in the failure of virus launching. However, insertion of a few nucleotides between the 3 '-end of the viral genome and the ribozyme cleavage site did not affect virus generation although the insertion of a G-rich sequence noticeably reduced its efficiency. In either case, the virus generated had none of the extra sequence at the 3 '-end. The transcription termination site for the FLP gene of the $2 \mu \mathrm{M}$ DNA is located $0.7-\mathrm{kb}$ downstream of the 3 '-terminus of the viral genome in the vector. Therefore, there is an activity capable of eliminating a short extra sequence but not a longer one from the viral 3 '-end. This suggests the involvement of a 3 '-exonuclease such as the exosome rather than an endonuclease in this process. Thus, our 20S RNA virus launching system may provide a convenient and sensitive method to analyze the processing of mRNAs at the $5^{\prime}$ - and $3^{\prime}$-ends in vivo.

Unlike its generation from a launching vector, 20S RNA virus does not require SKI1 for replication. The virus even shows insensitivity to the antiviral activity of SKI1; the overexpression of SKI1 from a multicopy vector or its deletion did not affect 20S RNA virus significantly. It is in stark contrast to the L-A virus. The deletion of SKI1 resulted in the derepression of L-A copy number 5-10-fold (in the presence of the satellite RNA M1, this effect is less evident ${ }^{4}$ because of suppression of L-A copy number by M1 (40)). Furthermore, overexpression of SKI1 suppressed $\mathrm{L}-\mathrm{A}$ virus and generated virus-free mitotic segregants at a high frequency. The $5^{\prime}$-terminal region of L-A positive strand is AUrich and has no obvious secondary structure, whereas the $20 \mathrm{~S}$ RNA genome has a strong secondary structure at the $5^{\prime}$-terminus, with the terminal nucleotide buried at the bottom of a long stem. This prompted us to hypothesize that the secondary structure at the $5^{\prime}$-terminus contributes to the resistance of $20 \mathrm{~S}$ RNA virus to the SKI1 anti-viral activity. We introduced two mutations into the viral genome to disturb the $5^{\prime}$-terminal structure and tested this hypothesis. As expected these mutations made the virus susceptible to SKI1. Especially, the mutant that had the more disturbed 5 ' structure (68GG69) could not be generated from a launching vector in the SKI1 wild-type background. In a ski1 $\Delta$ strain, however, these mutant viruses were

${ }^{4}$ R. Esteban and T. Fujimura, unpublished results. generated and replicated the same as the wild-type virus, indicating that the SKI1 5' -exonuclease is responsible for the instability of the mutant viruses in the wild-type strain. Furthermore, the 68GG69 mutant virus launched in a ski1s strain was greatly suppressed by overexpression of SKI1, whereas the wildtype virus was not. This indicates that the suppression of the mutant virus by SKI1 is not related to the launching process of the virus. We also demonstrated that these mutations had no direct effects on translation to decode p91 or on the formation of complexes with $\mathrm{p} 91$. Thus these data confirm our hypothesis that the secondary structure at the $5^{\prime}$-terminus is important to protect the 20S RNA genome from the SKI1 5' -exonuclease.

In a $S K I 1$ strain the $69 \mathrm{G}$ and $68 \mathrm{GG} 69$ mutations reduced the formation of complexes to 30 and $10 \%$ (basal level), respectively, compared with the wild-type RNA, whereas the same mutations did not affect the formation of complexes in a ski $1 \Delta$ strain. This indicates that the interaction of $\mathrm{p} 91$ with the $5^{\prime}$ cis site (nt 72-104) does not protect the viral genome from the SKI1 5' -exonuclease. Therefore, the $5^{\prime}$-terminal secondary structure itself is accountable for the resistance of $20 \mathrm{~S}$ RNA virus to the Ski1p digestion. One of the major roles for the positive strand 20S RNA genome during its replication cycle is to translate p91. The initiation codon of p91 is located at the $5^{\prime}$-side of the $5^{\prime}$-terminal stem structure (Fig. $1 B$ ). It may be speculated that the intricate secondary structure (nt 1-71) at the $5^{\prime}$-terminus has dual roles: one to protect the viral genome from $5^{\prime}$-exonucleases and the other to promote translation of p91 from an RNA template that appears to have no $5^{\prime}$ cap structure. 23S RNA virus, a virus closely related to 20S RNA virus found in the same host, also possesses a very similar secondary structure at the $5^{\prime}$-terminus of the 23S RNA genome (3). The initiation codon for its RNA polymerase p104 is located in the middle of the $5^{\prime}$-terminal long stem. This virus is also resistant to SKI1 overexpression. ${ }^{4}$ Therefore, the $5^{\prime}$-terminal structure of the 23S RNA genome may have similar dual roles. In the $20 \mathrm{~S}$ RNA/p91 complex, if p91 bound to the $5^{\prime}$-terminal structure, then such binding might interfere with p91 translation. Sitting on the adjacent structure (nt 72-104) instead, p91 may, by taking advantage of its proximity, sense or influence translational events from the initiation codon. Previously, we observed a weak protection from hydroxyl radical cleavages in the ribonucleoprotein complexes at positions 61 and 62, just opposite to the initiation codon in the $5^{\prime}$-terminal stem (18). Progression of the translating ribosome may displace p 91 from the $5^{\prime}$ cis site. Although the interactions of p91 at the $5^{\prime}$ and $3^{\prime}$ cis sites are coordinated, the remaining interaction with the central cis site would prevent the complete dissociation of p91 from the viral genome. 20S RNA virus has a single viral protein p91 and exists as a ribonucleoprotein complex composed of the viral genome and p91 in 1:1 stoichiometry. Through interactions at the $5^{\prime}$, central, and 3' cis sites, p91 may sense the current status of the complex on translation or replication (negative strand synthesis). This suggests that the ribonucleoprotein complex is not static but dynamic in structure and function.

RNA viruses, as obligatory intracellular parasites, have to propagate in the cell without being destroyed or neutralized by the host defense. Here, we have shown that the SKI1 gene has a strong anti L-A virus activity. The overexpression of the gene 


\section{Resistance of 20S RNA Virus to SKI1 Suppression}

product could even eliminate the virus from the cells. Although the wild-type 20S RNA virus is quite resistant to SKI1, mutant viruses modified at the $5^{\prime}$-end became susceptible to $S K I 1$ suppression. Our results suggest that SKI1 is part of the host defense against RNA viruses by virtue of its exonuclease activity. Perhaps L-A virus alleviates its deadly effects by sequestering the genome into intracellular particles, whereas 20S RNA virus has evolved such a way that the RNA genome itself becomes resistant to the enzyme by having a strong secondary structure at the $5^{\prime}$-end. It was reported that in vitro transcripts of L-A virus had diphosphates at their $5^{\prime}$-ends (41). Our preliminary data suggest that 20S RNA genome has neither a capped structure nor a monophosphate at the $5^{\prime}$-end. ${ }^{4}$ It remains to be clarified whether these viral genomes are directly subjected to SKI1 degradation or need to be processed prior to its action.

Acknowledgment-We thank Pilar Gómez Jiménez for invaluable technical support.

\section{REFERENCES}

1. Rodríguez-Cousiño, N., Esteban, L. M., and Esteban, R. (1991) J. Biol. Chem. 266, 12772-12778

2. Matsumoto, Y., and Wickner, R. B. (1991) J. Biol. Chem. 266, $12779-12783$

3. Rodríguez-Cousiño, N., Solórzano, A., Fujimura, T., and Esteban, R. (1998) J. Biol. Chem. 273, 20363-20371

4. Widner, W. R., Matsumoto, Y., and Wickner, R. B. (1991) Mol. Cell Biol. 11, 2905-2908

5. García-Cuéllar, M. P., Esteban, L. M., Fujimura, T., Rodríguez-Cousiño, N., and Esteban, R. (1995) J. Biol. Chem. 270, 20084-20089

6. Parker, R., and Song, H. (2004) Nat. Struct. Mol. Biol. 11, 121-127

7. Wilusz, C. J., Wormington, M., and Peltz, S. W. (2001) Nat. Rev. Mol. Cell Biol. 2, 237-246

8. Mitchell, P., Petfalski, E., Shevchenko, A., Mann, M., and Tollervey, D. (1997) Cell 91, 457-466

9. Jacobs Anderson, J. S., and Parker, R. (1998) EMBO J. 17, 1497-1506

10. Solinger, J. A., Pascolini, D., and Heyer, W. D. (1999) Mol. Cell Biol. 19, $5930-5942$

11. Stevens, A. (1980) J. Biol. Chem. 255, 3080-3085

12. Tucker, M., and Parker, R. (2000) Annu. Rev. Biochem. 69, 571-595

13. Stevens, A. (2001) Methods Enzymol. 342, 251-259
14. Toh-e, A., Guerry, P., and Wickner, R. B. (1978) J. Bacteriol. 136, 1002-1007

15. Wickner, R. B. (1986) Annu. Rev. Biochem. 55, 373-395

16. Johnson, A. W., and Kolodner, R. D. (1995) Mol. Cell Biol. 15, 2719-2727

17. Solórzano, A., Rodríguez-Cousiño, N., Esteban, R., and Fujimura, T. (2000) J. Biol. Chem. 275, 26428-26435

18. Fujimura, T., and Esteban, R. (2007) J. Biol. Chem. 282, 19011-19019

19. Esteban, R., Vega, L., and Fujimura, T. (2005) J. Biol. Chem. 280, 33725-33734

20. Ridley, S. P., Sommer, S. S., and Wickner, R. B. (1984) Mol. Cell Biol. 4, 761-770

21. Wickner, R. B. (1980) Cell 21, 217-226

22. Wejksnora, P. J., and Haber, J. E. (1978) J. Bacteriol. 134, 246-260

23. Mortimer, R. K., and Hawthorne, D. C. (1975) Methods Cell Biol. 11, 221-233

24. Conde, J., and Fink, G. R. (1976) Proc. Natl. Acad. Sci. U. S. A. 73, 3651-3655

25. Varshney, U., Lee, C.-P., and RajBhandary, U. L. (1991) J. Biol. Chem. 266, 24712-24718

26. Esteban, R., Fujimura, T., and Wickner, R. B. (1989) EMBO J. 8, 947-954

27. Fujimura, T., Esteban, R., Esteban, L. M., and Wickner, R. B. (1990) Cell 62, $819-828$

28. Maniatis, T., Fritsch, E. F., and Sambrook, J. (1993) Molecular Cloning: A Laboratory Manual, pp. 202-203, Cold Spring Harbor, NY

29. Sikorski, R. S., and Hieter, P. (1989) Genetics 122, 19-27

30. Wickner, R. B., Icho, T., Fujimura, T., and Widner, W. R. (1991) J. Virol. 65, 155-161

31. Bonnerot, C., Boeck, R., and Lapeyre, B. (2000) Mol. Cell Biol. 20, $5939-5946$

32. Coller, J. M., Tucker, M., Sheth, U., Valencia-Sánchez, M. A., and Parker, R. (2001) RNA 7, 1717-1727

33. Fisher, N., and Weis, K. (2002) EMBO J. 21, 2788-2797

34. Cheng, R. H., Caston, J. R., Wang, G.-J., Gu, F., Smith, T. J., Baker, T. S., Bozarth, R. F., Trus, B. L., Cheng, N., Wickner, R. B., and Steven, A. C. (1994) J. Mol. Biol. 244, 255-258

35. Caston, J. R., Trus, B. L., Booy, F. P., Wickner, R. B., Wall, J. S., and Steven, A. C. (1997) J. Cell Biol. 138, 975-985

36. Decker, C. J., and Parker, R. (1993) Genes Dev. 7, 1632-1643

37. Esteban, R., and Fujimura, T. (2003) Proc. Natl. Acad. Sci. U. S. A. 100, $2568-2573$

38. Johnson, A. W. (1997) Mol. Cell Biol. 17, 6122-6130

39. Fekete, Z. F., Ellis, T. P., Schonauer, M. S., and Dieckmann, C. L. (2008) J. Biol. Chem. 283, 3767-3772

40. Ball, S. G., Tirtiaux, C., and Wickner, R. B. (1984) Genetics 107, 199-217

41. Nemeroff, M. E., and Bruenn, J. A. (1987) J. Biol. Chem. 262, 6785-6787 


\section{BIBLIOGRAFÍA}

"Dejamos de temer aquello que se ha aprendido a entender" MARIE CURIE 


\section{BIBLIOGRAFÍA}

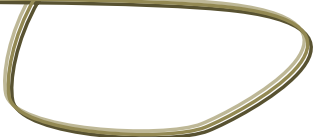

1. Alwine, J.C., Kemp, D.J. y Stark, G.R. (1977). Method for detection of specific RNAs in agarose gels by transfer to diazobenzyloxymethyl-paper and hybridization with DNA probes. Proc Natl Acad Sci U S A 74, 5350-5354.

2. Anderson, J.S. y Parker, R.P. (1998). The $3^{\prime}$ to $5^{\prime}$ degradation of yeast mRNAs is a general mechanism for mRNA turnover that requires the SKI2 DEVH box protein and $3^{\prime}$ to $5^{\prime}$ exonucleases of the exosome complex. EMBO J 17, 1497-1506.

3. Araki, Y., Takahashi, S., Kobayashi, T., Kajiho, H., Hoshino, S. y Katada, T. (2001). Ski7p G protein interacts with the exosome and the Ski complex for 3'-to-5' mRNA decay in yeast. EMBO J 20, 4684-4693.

4. Argos, P. (1988). A sequence motif in many polymerases. Nucleic Acids Res 16, 9909-9916.

5. Arora, C., Kee, K., Maleki, S. y Keeney, S. (2004). Antiviral protein Ski8 is a direct partner of Spo11 in meiotic DNA break formation, independent of its cytoplasmic role in RNA metabolism. Mol Cell 13, 549-559.

6. Benard, L., Carroll, K., Valle, R.C. y Wickner, R.B. (1998). Ski6p is a homolog of RNA-processing enzymes that affects translation of non-poly $(A) m R N A s$ and 605 ribosomal subunit biogenesis. Mol Cell Biol 18, 2688-2696.

7. Bentley, N.J., Fitch, I.T. y Tuite, M.F. (1992). The small heat-shock protein Hsp26 of Saccharomyces cerevisiae assembles into a high molecular weight aggregate. Yeast 8, 95-106.

8. Birnboim, H.C. y Doly, J. (1979). A rapid alkaline extraction procedure for screening recombinant plasmid DNA. Nucleic Acids Res 7, 1513-1523.

9. Blumenthal, T. y Carmichael, G.G. (1979). RNA replication: function and structure of Qbetareplicase. Annu Rev Biochem 48, 525-548.

10. Bouveret, E., Rigaut, G., Shevchenko, A., Wilm, M. y Seraphin, B. (2000). A Sm-like protein complex that participates in mRNA degradation. EMBO J 19, 1661-1671.

11. Bradford, M.M. (1976). A rapid and sensitive method for the quantitation of microgram quantities of protein utilizing the principle of protein-dye binding. Anal Biochem 72, 248-254.

12. Brown, J.T., Bai, X. y Johnson, A.W. (2000). The yeast antiviral proteins Ski2p, Ski3p, and Ski8p exist as a complex in vivo. RNA 6, 449-457. 
13. Bruenn, J.A. (1993). A closely related group of RNA-dependent RNA polymerases from doublestranded RNA viruses. Nucleic Acids Res 21, 5667-5669.

14. Cai, G., Myers, K., Hillman, B.I. y Fry, W.E. (2009). A novel virus of the late blight pathogen, Phytophthora infestans, with two RNA segments and a supergroup 1 RNA-dependent RNA polymerase. Virology 392, 52-61.

15. Cole, T.E., Hong, Y., Brasier, C.M. y Buck, K.W. (2000). Detection of an RNA-dependent RNA polymerase in mitochondria from a mitovirus-infected isolate of the Dutch Elm disease fungus, Ophiostoma novo-ulmi. Virology 268, 239-243.

16. Conde, J. y Fink, G.R. (1976). A mutant of Saccharomyces cerevisiae defective for nuclear fusion. Proc Natl Acad Sci U S A 73, 3651-3655.

17. Cho, H.D., Tomita, K., Suzuki, T. y Weiner, A.M. (2002). U2 small nuclear RNA is a substrate for the CCA-adding enzyme (tRNA nucleotidyltransferase). J Biol Chem 277, 3447-3455.

18. de la Cruz, J., Kressler, D. y Linder, P. (1999). Unwinding RNA in Saccharomyces cerevisiae: DEAD-box proteins and related families. Trends Biochem Sci 24, 192-198.

19. Decker, C.J. y Parker, R. (1993). A turnover pathway for both stable and unstable mRNAs in yeast: evidence for a requirement for deadenylation. Genes Dev 7, 1632-1643.

20. Dunckley, T., Tucker, M. y Parker, R. (2001). Two related proteins, Edc1p and Edc2p, stimulate mRNA decapping in Saccharomyces cerevisiae. Genetics 157, 27-37.

21. Dziembowski, A., Lorentzen, E., Conti, E. y Seraphin, B. (2007). A single subunit, Dis3, is essentially responsible for yeast exosome core activity. Nat Struct Mol Biol 14, 15-22.

22. Esteban, L.M., Rodríguez-Cousiño, N. y Esteban, R. (1992). T double-stranded RNA (dsRNA) sequence reveals that $T$ and $W$ dsRNAs form a new RNA family in Saccharomyces cerevisiae. Identification of 23 S RNA as the single-stranded form of $T$ dsRNA. J Biol Chem 267, 1087410881.

23. Esteban, L.M. (1993). Caracterización molecular de los RNAs virales $T$ y $23 S$ RNA de Saccharomyces cerevisiae. Departamento de Microbiología y Genética. Salamanca.

24. Esteban, L.M., Fujimura, T., Garcia-Cuellar, M. y Esteban, R. (1994). Association of yeast viral 23 S RNA with its putative RNA-dependent RNA polymerase. J Biol Chem 269, 29771-29777.

25. Esteban, R. y Fujimura, T. (2003). Launching the yeast 23S RNA Narnavirus shows 5' and 3' cisacting signals for replication. Proc Natl Acad Sci U S A 100, 2568-2573.

26. Esteban, R., Vega, L. y Fujimura, T. (2005). Launching of the yeast 20 S RNA narnavirus by expressing the genomic or antigenomic viral RNA in vivo. J Biol Chem 280, 33725-33734. 
27. Esteban, R., Fujumura, T. (2006). Yeast narnavirus replication. In: Recent avances in RNA virus replication, ed. K.L. Hefferon, Kerala: Transworld Research Network, 171-194.

28. Esteban, R. y Rodríguez-Cousiño, N. (2008). 235 RNA-derived replicon as a 'molecular tag' for monitoring inoculated wine yeast strains. Yeast 25, 359-369.

29. Esteban, R., Vega, L. y Fujimura, T. (2008). 20S RNA narnavirus defies the antiviral activity of SKI1/XRN1 in Saccharomyces cerevisiae. J Biol Chem 283, 25812-25820.

30. Fauquet, C.M., Mayo, M. A, Maniloff, J., Desselberger, U., Ball., L. A. (2005). Virus Taxonomy. Eighth Report of the International Committee on Taxonomy Viruses. Academic Press: San Diego.

31. Fekete, Z., Ellis, T.P., Schonauer, M.S. y Dieckmann, C.L. (2008). Pet127 governs a 5' --> 3'exonuclease important in maturation of apocytochrome b mRNA in Saccharomyces cerevisiae. J Biol Chem 283, 3767-3772.

32. Ferreira, R.M., de Andrade, L.R., Dutra, M.B., de Souza, M.F., Flosi Paschoalin, V.M. y Silva, J.T. (2006). Purification and characterization of the chaperone-like Hsp26 from Saccharomyces cerevisiae. Protein Expr Purif 47, 384-392.

33. Fry, W.E., Goodwyn, S. B. (1997). Resurgence of the Irish potato famine fungus. Bioscience 47, 363-371.

34. Fujimura, T., Esteban, R. y Wickner, R.B. (1986). In vitro L-A double-stranded RNA synthesis in virus-like particles from Saccharomyces cerevisiae. Proc Natl Acad Sci U S A 83, 4433-4437.

35. Fujimura, T., Solórzano, A. y Esteban, R. (2005). Native replication intermediates of the yeast 20S RNA virus have a single-stranded RNA backbone. J Biol Chem 280, 7398-7406.

36. Fujimura, T., Esteban, R., Esteban, L.M. y Wickner, R.B. (1990). Portable encapsidation signal of the L-A double-stranded RNA virus of S. cerevisiae. Cell 62, 819-828.

37. Fujimura, T. y Esteban, R. (2004a). Bipartite 3'-cis-acting signal for replication in yeast $23 \mathrm{~S}$ RNA virus and its repair. J Biol Chem 279, 13215-13223.

38. Fujimura, T. y Esteban, R. (2004b). The bipartite 3'-cis-acting signal for replication is required for formation of a ribonucleoprotein complex in vivo between the viral genome and its RNA polymerase in yeast $23 S$ RNA virus. J Biol Chem 279, 44219-44228.

39. Fujimura, T. y Wickner, R.B. (1987). L-A double-stranded RNA viruslike particle replication cycle in Saccharomyces cerevisiae: particle maturation in vitro and effects of mak10 and pet18 mutations. Mol Cell Biol 7, 420-426.

40. Fujimura, T. y Esteban, R. (2007). Interactions of the RNA polymerase with the viral genome at the 5'- and 3'-ends contribute to 20S RNA narnavirus persistence in yeast. J Biol Chem 282, 19011-19019. 
41. García-Cuéllar, M.P., Esteban, L.M., Fujimura, T., Rodríguez-Cousiño, N. y Esteban, R. (1995). Yeast viral 20 S RNA is associated with its cognate RNA-dependent RNA polymerase. J Biol Chem 270, 20084-20089.

42. Gardiner, J.M., Bullard, S.A., Chrome, C. y Malone, R.E. (1997). Molecular and genetic analysis of REC103, an early meiotic recombination gene in yeast. Genetics 146, 1265-1274.

43. Garvik, B. y Haber, J.E. (1978). New cytoplasmic genetic element that controls $20 \mathrm{~S}$ RNA synthesis during sporulation in yeast. J Bacteriol 134, 261-269.

44. Golub, E.I. (1988). 'One minute' transformation of competent E. coli by plasmid DNA. Nucleic Acids Res 16, 1641.

45. Gottlieb, M. y Chavko, M. (1987). Silver staining of native and denatured eucaryotic DNA in agarose gels. Anal Biochem 165, 33-37.

46. Guan, H. y Simon, A.E. (2000). Polymerization of nontemplate bases before transcription initiation at the $3^{\prime}$ ends of templates by an RNA-dependent RNA polymerase: an activity involved in 3' end repair of viral RNAs. Proc Natl Acad Sci U S A 97, 12451-12456.

47. Hanahan, D. (1983). Studies on transformation of Escherichia coli with plasmids. J Mol Biol $166,557-580$.

48. He, W. y Parker, R. (2000). Functions of Lsm proteins in mRNA degradation and splicing. Curr Opin Cell Biol 12, 346-350.

49. Hema, M., Gopinath, K. y Kao, C. (2005). Repair of the tRNA-like CCA sequence in a multipartite positive-strand RNA virus. J Virol 79, 1417-1427.

50. Hernandez, H., Dziembowski, A., Taverner, T., Seraphin, B. y Robinson, C.V. (2006). Subunit architecture of multimeric complexes isolated directly from cells. EMBO Rep 7, 605-610.

51. Hitzeman, R.A., Leung, D.W., Perry, L.J., Kohr, W.J., Levine, H.L. y Goeddel, D.V. (1983). Secretion of human interferons by yeast. Science 219, 620-625.

52. Hollings, M. (1962). Viruses Associated with A Die-Back Disease of Cultivated Mushroom. Nature 196, 962 - 965.

53. Houseley, J., LaCava, J. y Tollervey, D. (2006). RNA-quality control by the exosome. Nat Rev Mol Cell Biol 7, 529-539.

54. Hsu, C.L. y Stevens, A. (1993). Yeast cells lacking $5^{\prime}-->3^{\prime}$ exoribonuclease 1 contain mRNA species that are poly $(A)$ deficient and partially lack the $5^{\prime}$ cap structure. Mol Cell Biol 13, 48264835. 
55. Interthal, H., Bellocq, C., Bahler, J., Bashkirov, V.I., Edelstein, S. y Heyer, W.D. (1995). A role of Sep1 (= Kem1, Xrn1) as a microtubule-associated protein in Saccharomyces cerevisiae. EMBO J $14,1057-1066$.

56. Ito, H., Fukuda, Y., Murata, K. y Kimura, A. (1983). Transformation of intact yeast cells treated with alkali cations. J Bacteriol 153, 163-168.

57. Janda, M. y Ahlquist, P. (1993). RNA-dependent replication, transcription, and persistence of brome mosaic virus RNA replicons in S. cerevisiae. Cell 72, 961-970.

58. Johnson, A.W. (1997). Rat1p and Xrn1p are functionally interchangeable exoribonucleases that are restricted to and required in the nucleus and cytoplasm, respectively. Mol Cell Biol 17, 6122-6130.

59. Johnson, A.W. y Kolodner, R.D. (1995). Synthetic lethality of sep1 (xrn1) ski2 and sep1 (xrn1) ski3 mutants of Saccharomyces cerevisiae is independent of killer virus and suggests a general role for these genes in translation control. Mol Cell Biol 15, 2719-2727.

60. Joyce, C.M. y Grindley, N.D. (1984). Method for determining whether a gene of Escherichia coli is essential: application to the polA gene. J Bacteriol 158, 636-643.

61. Kadowaki, K. y Halvorson, H.O. (1971a). Appearance of a new species of ribonucleic acid during sporulation in Saccharomyces cerevisiae. J Bacteriol 105, 826-830.

62. Kadowaki, K. y Halvorson, H.O. (1971b). Isolation and properties of a new species of ribonucleic acid synthesized in sporulating cells of Saccharomyces cerevisiae. J Bacteriol 105, 831-836.

63. Kamer, G. y Argos, P. (1984). Primary structural comparison of RNA-dependent polymerases from plant, animal and bacterial viruses. Nucleic Acids Res 12, 7269-7282.

64. Kim, J., Ljungdahl, P.O. y Fink, G.R. (1990). kem mutations affect nuclear fusion in Saccharomyces cerevisiae. Genetics 126, 799-812.

65. Knipe, D.M.E., Howley, P. M., Griffin, D. E., Lamb, R. A., Martin, M. A., Roizman, B., Straus, S. T. (2006). Fields Virology. Lippincott Williams \& Wilkins.

66. Kunkel, T.A. (1985). Rapid and efficient site-specific mutagenesis without phenotypic selection. Proc Natl Acad Sci U S A 82, 488-492.

67. Laemmli, U.K. (1970). Cleavage of structural proteins during the assembly of the head of bacteriophage T4. Nature 227, 680-685.

68. Larimer, F.W., Hsu, C.L., Maupin, M.K. y Stevens, A. (1992). Characterization of the XRN1 gene encoding a 5'-->3' exoribonuclease: sequence data and analysis of disparate protein and mRNA levels of gene-disrupted yeast cells. Gene 120, 51-57. 
69. Lehner, B. y Sanderson, C.M. (2004). A protein interaction framework for human mRNA degradation. Genome Res 14, 1315-1323.

70. Levy, J.A., Fraenkel-Conrat, H., and Owens, R. A. (1994). Virology. Prentice Hall, England Cliffs: New Jersey.

71. Liu, Q., Greimann, J.C. y Lima, C.D. (2006). Reconstitution, activities, and structure of the eukaryotic RNA exosome. Cell 127, 1223-1237.

72. Liu, Y., Wimmer, E. y Paul, A.V. (2009). Cis-acting RNA elements in human and animal plusstrand RNA viruses. Biochim Biophys Acta 1789, 495-517.

73. Long, R.M. y McNally, M.T. (2003). mRNA decay: x (XRN1) marks the spot. Mol Cell 11, 11261128.

74. Maniatis, T., Fritsch, E. F., Sambrook, J. (1984). Molecular cloning. A laboratory manual. Cold Spring Harbor Lab.

75. Mans, R.M., Pleij, C.W. y Bosch, L. (1991). tRNA-like structures. Structure, function and evolutionary significance. Eur J Biochem 201, 303-324.

76. Masison, D.C., Blanc, A., Ribas, J.C., Carroll, K., Sonenberg, N. y Wickner, R.B. (1995). Decoying the cap- mRNA degradation system by a double-stranded RNA virus and poly(A)- mRNA surveillance by a yeast antiviral system. Mol Cell Biol 15, 2763-2771.

77. Mathews, D.H., Sabina, J., Zuker, M. y Turner, D.H. (1999). Expanded sequence dependence of thermodynamic parameters improves prediction of RNA secondary structure. J Mol Biol 288, 911-940.

78. Matsumoto, Y., Fishel, R. y Wickner, R.B. (1990). Circular single-stranded RNA replicon in Saccharomyces cerevisiae. Proc Natl Acad Sci U S A 87, 7628-7632.

79. Matsumoto, Y. y Wickner, R.B. (1991). Yeast 20 S RNA replicon. Replication intermediates and encoded putative RNA polymerase. J Biol Chem 266, 12779-12783.

80. Meselson, M. y Yuan, R. (1968). DNA restriction enzyme from E. coli. Nature 217, 1110-1114.

81. Meyer, F., Weber, H. y Weissmann, C. (1981). Interactions of $Q$ beta replicase with $Q$ beta RNA. J Mol Biol 153, 631-660.

82. Mitchell, P., Petfalski, E., Shevchenko, A., Mann, M. y Tollervey, D. (1997). The exosome: a conserved eukaryotic RNA processing complex containing multiple $3^{\prime}-->5^{\prime}$ exoribonucleases. Cell 91, 457-466.

83. Mortimer, R.K. y Hawthorne, D.C. (1975). Genetic mapping in yeast. Methods Cell Biol 11, 221233. 
84. Nagy, P.D., Carpenter, C.D. y Simon, A.E. (1997). A novel 3'-end repair mechanism in an RNA virus. Proc Natl Acad Sci U S A 94, 1113-1118.

85. Noueiry, A.O. y Ahlquist, P. (2003). Brome mosaic virus RNA replication: revealing the role of the host in RNA virus replication. Annu Rev Phytopathol 41, 77-98.

86. Panavas, T. y Nagy, P.D. (2003). Yeast as a model host to study replication and recombination of defective interfering RNA of Tomato bushy stunt virus. Virology 314, 315-325.

87. Pathak, R., Bogomolnaya, L.M., Guo, J. y Polymenis, M. (2005). A role for KEM1 at the START of the cell cycle in Saccharomyces cerevisiae. Curr Genet 48, 300-309.

88. Perrotta, A.T. y Been, M.D. (1990). The self-cleaving domain from the genomic RNA of hepatitis delta virus: sequence requirements and the effects of denaturant. Nucleic Acids Res 18, 6821-6827.

89. Perrotta, A.T. y Been, M.D. (1991). A pseudoknot-like structure required for efficient selfcleavage of hepatitis delta virus RNA. Nature 350, 434-436.

90. Poch, O., Sauvaget, I., Delarue, M. y Tordo, N. (1989). Identification of four conserved motifs among the RNA-dependent polymerase encoding elements. EMBO J 8, 3867-3874.

91. Pogany, J. y Nagy, P.D. (2008). Authentic replication and recombination of Tomato bushy stunt virus RNA in a cell-free extract from yeast. J Virol 82, 5967-5980.

92. Ridley, S.P., Sommer, S.S. y Wickner, R.B. (1984). Superkiller mutations in Saccharomyces cerevisiae suppress exclusion of M2 double-stranded RNA by L-A-HN and confer cold sensitivity in the presence of $M$ and $L-A-H N$. Mol Cell Biol 4, 761-770.

93. Rodríguez-Cousiño, N., Esteban, L.M. y Esteban, R. (1991). Molecular cloning and characterization of $W$ double-stranded RNA, a linear molecule present in Saccharomyces cerevisiae. Identification of its single-stranded RNA form as 20 S RNA. J Biol Chem 266, 1277212778.

94. Rodríguez-Cousiño, N. y Esteban, R. (1992). Both yeast $W$ double-stranded RNA and its singlestranded form 20S RNA are linear. Nucleic Acids Res 20, 2761-2766.

95. Rodríguez-Cousiño, N., Solórzano, A., Fujimura, T. y Esteban, R. (1998). Yeast positive-stranded virus-like RNA replicons. 205 and 23 RNA terminal nucleotide sequences and $3^{\prime}$ end secondary structures resemble those of RNA coliphages. J Biol Chem 273, 20363-20371.

96. Sanger, F., Nicklen, S. y Coulson, A.R. (1977). DNA sequencing with chain-terminating inhibitors. Proc Natl Acad Sci U S A 74, 5463-5467. 
97. Schaeffer, D., Tsanova, B., Barbas, A., Reis, F.P., Dastidar, E.G., Sanchez-Rotunno, M., Arraiano, C.M. y van Hoof, A. (2009). The exosome contains domains with specific endoribonuclease, exoribonuclease and cytoplasmic mRNA decay activities. Nat Struct Mol Biol 16, 56-62.

98. Schimmel, P. y Ribas de Pouplana, L. (1995). Transfer RNA: from minihelix to genetic code. Cell 81, 983-986.

99. Searfoss, A.M. y Wickner, R.B. (2000). 3' poly(A) is dispensable for translation. Proc Natl Acad Sci U S A 97, 9133-9137.

100. Serviene, E., Jiang, Y., Cheng, C.P., Baker, J. y Nagy, P.D. (2006). Screening of the yeast yTHC collection identifies essential host factors affecting tombusvirus RNA recombination. J Virol 80 , 1231-1241.

101. Sheth, U. y Parker, R. (2003). Decapping and decay of messenger RNA occur in cytoplasmic processing bodies. Science 300, 805-808.

102. Shi, J.P., Martinis, S.A. y Schimmel, P. (1992). RNA tetraloops as minimalist substrates for aminoacylation. Biochemistry 31, 4931-4936.

103. Sikorski, R.S. y Hieter, P. (1989). A system of shuttle vectors and yeast host strains designed for efficient manipulation of DNA in Saccharomyces cerevisiae. Genetics 122, 19-27.

104. Smith-Vikos, T. (2009). A new Narnavirus that infects the Late Blight Pathogen, Phytophtora infestans, with a supergroup 2 RNA-dependent. College of Agriculture and Life Sciences, Biological Sciences. University of Cornell.

105. Solórzano, A., Rodríguez-Cousiño, N., Esteban, R. y Fujimura, T. (2000). Persistent yeast singlestranded RNA viruses exist in vivo as genomic RNA.RNA polymerase complexes in 1:1 stoichiometry. J Biol Chem 275, 26428-26435.

106. Solórzano, A. (2001). Caracterización del los Narnavirus $20 S$ RNA y $23 S$ RNA de S. cerevisiae: Formación de complejos ribonucleoproteicos entre los RNAs genómicos y sus RNA polimerasas como estrategia de supervivencia viral. Departamento de Microbiología y Genética. Salamanca.

107. Sprinzl, M., Hartmann, T., Weber, J., Blank, J. y Zeidler, R. (1989). Compilation of tRNA sequences and sequences of tRNA genes. Nucleic Acids Res 17 Suppl, r1-172.

108. Stevens, A. (2001). 5'-exoribonuclease 1: Xrn1. Methods Enzymol 342, 251-259.

109. Studier, F.W. y Moffatt, B.A. (1986). Use of bacteriophage T7 RNA polymerase to direct selective high-level expression of cloned genes. J Mol Biol 189, 113-130.

110. Switzer, R.C., 3rd, Merril, C.R. y Shifrin, S. (1979). A highly sensitive silver stain for detecting proteins and peptides in polyacrylamide gels. Anal Biochem 98, 231-237. 
111. Synowsky, S.A. y Heck, A.J. (2008). The yeast Ski complex is a hetero-tetramer. Protein Sci 17, 119-125.

112. Tabor, S. y Richardson, C.C. (1985). A bacteriophage T7 RNA polymerase/promoter system for controlled exclusive expression of specific genes. Proc Natl Acad Sci U S A 82, 1074-1078.

113. Teramoto, T., Kohno, Y., Mattoo, P., Markoff, L., Falgout, B. y Padmanabhan, R. (2008). Genome 3'-end repair in dengue virus type 2. RNA 14, 2645-2656.

114. Tharun, S., He, W., Mayes, A.E., Lennertz, P., Beggs, J.D. y Parker, R. (2000). Yeast Sm-like proteins function in mRNA decapping and decay. Nature 404, 515-518.

115. Toh, E.A., Guerry, P. y Wickner, R.B. (1978). Chromosomal superkiller mutants of Saccharomyces cerevisiae. J Bacteriol 136, 1002-1007.

116. Toh, E.A. y Wickner, R.B. (1980). "Superkiller" mutations suppress chromosomal mutations affecting double-stranded RNA killer plasmid replication in Saccharomyces cerevisiae. Proc Natl Acad Sci U S A 77, 527-530.

117. Tucker, M., Staples, R.R., Valencia-Sanchez, M.A., Muhlrad, D. y Parker, R. (2002). Ccr4p is the catalytic subunit of a Ccr4p/Pop2p/Notp mRNA deadenylase complex in Saccharomyces cerevisiae. EMBO J 21, 1427-1436.

118. van Hoof, A., Staples, R.R., Baker, R.E. y Parker, R. (2000). Function of the ski4p (Cs/4p) and Ski7p proteins in 3'-to-5' degradation of mRNA. Mol Cell Biol 20, 8230-8243.

119. Van Regenmortel, M.H.V., Fauquet, C. M., Bishop, D. H. L. (2000). Virus Taxonomy. Seventh Report of the International Committee on Taxonomy Viruses. Academic Press: San Diego.

120. Wang, L., Lewis, M.S. y Johnson, A.W. (2005). Domain interactions within the Ski2/3/8 complex and between the Ski complex and Ski7p. RNA 11, 1291-1302.

121. Wesolowski, M. y Wickner, R.B. (1984). Two new double-stranded RNA molecules showing non-mendelian inheritance and heat inducibility in Saccharomyces cerevisiae. Mol Cell Biol 4, 181-187.

122. White, D.O., Fenner, F. J. (1994). Viral Replication. In: Medical Virology, San Diego: Academic Press, 31-54.

123. Wickner, R.B. (1996). Prions and RNA viruses of Saccharomyces cerevisiae. Annu Rev Genet 30, 109-139.

124. Wickner, R.B., Icho, T., Fujimura, T. y Widner, W.R. (1991). Expression of yeast L-A doublestranded RNA virus proteins produces derepressed replication: a ski- phenocopy. J Virol 65, 155-161. 
125. Widner, W.R., Matsumoto, Y. y Wickner, R.B. (1991). Is 20 S RNA naked? Mol Cell Biol 11, 2905-2908.

126. Widner, W.R. y Wickner, R.B. (1993). Evidence that the SKI antiviral system of Saccharomyces cerevisiae acts by blocking expression of viral mRNA. Mol Cell Biol 13, 4331-4341.

127. You, S. y Padmanabhan, R. (1999). A novel in vitro replication system for Dengue virus. Initiation of RNA synthesis at the 3'-end of exogenous viral RNA templates requires 5'- and 3'terminal complementary sequence motifs of the viral RNA. J Biol Chem 274, 33714-33722.

128. Zuker, M. (2003). Mfold web server for nucleic acid folding and hybridization prediction. Nucleic Acids Res 31, 3406-3415. 
"En el punto en el que se detiene la ciencia, empieza la imaginación"

HEYENDHAL 